Vol 10, No. 2 (November 2019-April 2020)

https://doi.org/10.26619/1647-7251.10.2

\title{
ARTICLES
}

The UN in Conflict Resolution: The Case of East Timor* - Francisco Proença Garcia, Mónica Dias e Raquel Duque - pp 1-11

Opportunities for conflict prevention. Lessons from the Economic Community of West African States (ECOWAS)* - Jara Cuadrado - pp 12-32

The influence of climate change on the escalating communal conflict between herdsmen and farmers: the case of the Fulani ethnic group in Nigeria* - Gustavo Furini - pp 33-52

European Union, Russia and the MH17 case: strategic narratives' analysis (2014-2019)* - Paulo Ramos e Alena Vieira - pp 53-67

Global Security Assemblages: mapping the field* - Jovana Jezdimirovic Ranito - pp 68-81

Why Is It Important to Use Regional Lenses When We Look into Civil Conflicts in the MENA? - Samer Hamati - pp 82-91

China's cooperation in Africa in the area of physical connectivity infrastructure. The case of the Mombasa-Nairobi railway line - María Noel Dussort e Agustina Marchetti - pp 92-109

The 3 Seas Initiative: Geopolitics and Infrastructure - Bernardo Calheiros - pp 110-123

Rights of migrants: notes on the jurisprudence of the Inter-American Court of Human Rights - María Teresa Palacios Sanabria - pp 124-140

Between freedom of contract and the principle of good faith: an inside view on the reform of private law of Kazakhstan - Kamal Sabirov, Venera Konussova e Marat Alenov - pp 141-151

The Observance of Human Right to Freedom from Torture in Professional Activity of the National Police of Ukraine (Article 3 of the Convention for the Protection of Human Rights and Fundamental Freedoms) - Andrii Voitsikhovskyi, Vadym Seliukov, Oleksandr Bakumov e Olena Ustymenko - pp 152-165

* Special issue of articles presented at the 1st International Conference on Conflict Resolution and Peace Studies that took place at UAL on the $29^{\text {th }}$ and $30^{\text {th }}$ of November 2018. 


\section{THE UN IN CONFLICT RESOLUTION: THE CASE OF EAST TIMOR}

\section{Francisco Proença Garcia}

franciscoproencagarcia@iep.lisboa.ucp.pt Reserve Lieutenant Colonel. Associate Professor with Aggregation at the Institute of Political Studies of Universidade Católica Portuguesa (Portugal). Invited Professor at the Faculty of Law of Universidade Nova de Lisboa and at Instituto Universitário Militar. He was Planning Officer of the PKF/UNTAET Central Sector Command Headquarters in East Timor (2001). He is Director of

Sociedade de Geografia

Mónica Dias

moni@iep.lisboa.ucp.pt

Coordinator of the Doctoral Programme at Institute of Political Studies, Universidade Católica Portuguesa (Portugal). PhD in Political Science and International Relations, conducts research in Conflict and Peace Studies, Democracy Studies, Contemporary International Politics and Human Rights. Taught at University of Cologne and United States Information Agency Summer School.

Raquel Duque

raquelsantosduque@gmail.com

Ph.D. in Political Science and International Relations: Security and Defence, Master in International Security and Terrorism. Invited Assistant Professor at the Institute of Political Studies, Universidade Católica Portuguesa, Portugal) and at the Instituto Superior de Ciências Policiais e Segurança Interna. Researcher at the ICPOL Research Centre, at the Research Centre of the Institute for Political Studies and at the Centre for Administration and Public Policy, ISCSP.

\section{Abstract}

The involvement of the United Nations in East Timor can be divided into four periods, including the anti-colonial period (1955-1974), the reaction period (1975-1982), the attenuation period (1983-1998) and the commitment period (from 1999). It is about this last period that this paper will focus by analysing the decisive steps of the UN, as a multilateral organization with a security mandate, in resolving the Timorese conflict and peacebuilding in that territory. This analysis will be guided by the proposals of the document "An Agenda for Peace" presented in 1992 by Boutros Boutros-Ghali, then Secretary-General of the United Nations, and the expectations he created in the field of peace operations. We are particularly interested in looking at the design of post-conflict peacebuilding missions and assessing the extent to which the (expected) capital gains from these operations compared to conventional peacekeeping missions would come to fruition or not. Thus, it is important to examine how the main missions were carried out, with special focus on the different actors, as well as to make a critical balance with some historical distance. In this context, it seems to us that the case of East Timor will be a good example to understand the need for a new approach to peacebuilding, as advocated in this Report, but which at a distance of more than 25 years becomes even more evident. The perception of peace as a continuous process that involves a whole sustainability network, and that depends above all on fostering and developing competences for peace (involving multiple and distinct actors facing constant coordination and negotiation challenges), therefore allows demanding greater commitment on the part of the Security Council, but also on that of the General Assembly in carrying out this difficult task in the context of the new world (dis) order.

\section{Keywords}

Peace Studies, International Organizations, Peacekeeping Operations, Governance and State Building, Timor-Leste

\section{How to cite this article}

Garcia, Francisco Proença; Dias, Mónica; Duque, Raquel (2019). "The UN in Conflict Resolution: the case of East Timor". JANUS.NET e-journal of International Relations, Vol. 10, N.0 2, November 2019-April 2020. Consulted [online] on the date of the last visit, https://doi.org/10.26619/1647-7251.10.2.1 


\section{The UN in conflict resolution}

The last decade of the twentieth century witnessed remarkable changes in the field of geopolitics that have shifted the artificial peace between the eastern bloc and the western bloc to a globe fragmented in a growing number of sovereign states and non-state actors with a high transnational role (especially for example, economic and financial groups, non-governmental organizations with the most diverse claims, organized crime networks or terrorist groups). These transformations were accompanied by major technological advances in various sectors such as communications, information, and military, which saw the evolution of armed and unarmed conflicts, notably in cyberspace war. The prevention of conflict between states was a central objective of the United Nations. However, the governing charter of this organization does not specify conflicts within the states which, in the post-Cold War environment, have been prevalent, with complex situations such as the Balkan war or the genocide in Rwanda, and have required a response from key actors in the international space.

Faced with an accelerated and complex international dynamic in the webs of interdependencies that are generated among the multiple actors of the new (and uncertain) world order, the then UN Secretary-General Boutros Boutros-Ghali understood the need to provide an answer adjusted to the new context, requiring the commitment of all states to the goal of peace. The Agenda for Peace. Preventive Diplomacy, Peacemaking and Peace-Keeping Report (United Nations, 1992) ${ }^{3}$ embodies BoutrosGhali's vision and proposes to transform the pathways leading to peace - in a manner complementary to the UN Charter that already provided for peacekeeping operations in Chapter VI and peace enforcement operations in Chapter VII.

Twenty-six years later, the UN remains the most recognized and comprehensive international forum for peacemaking, and Boutros-Ghali's legacy endures in stimulating

1 The translation of this article was co-funded by Instituto Camões in the framework of the 1st International Conference on Conflict Resolution and Peace Studies. Text translated by Carolina Peralta.

2 Special issue of articles presented at the 1st International Conference on Conflict Resolution and Peace Studies that took place at UAL on the $29^{\text {th }}$ and $30^{\text {th }}$ of November 2018.

3 Hereinafter referred to as an Agenda for Peace or simply Agenda. 


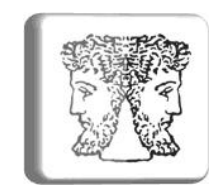

new conceptions of conflict resolution. Perhaps an element that underpins the durability of the Agenda still in 2018 is the innovative formula for post-conflict peace building, which encourages the development of research in peace studies and yields effective results on the ground. On the one hand, this document has declared a crucial premise for any peace debate in the new international system that traditional means of ending wars would be inappropriate to the configurations of modern conflicts. In this way, the Agenda for Peace seeks to establish a solid starting point for peace maintenance and, furthermore, introduces a new peace paradigm: peace as a mission that cannot be done but rather developed through the commitment of all those who have been affected by the conflict, that is, in a commitment extended to the whole of society.

In the wake of Immanuel Kant, a more complex foedus pacificum (1795) overlaps a pactum pacis and thus the peace solution advocated by the Agenda goes beyond mere political truce and advances towards the inclusion (i) of political institutions' reform ii) security, iii) rebuilding infrastructure, as well as economic, social and cultural capacities that empower people, stimulate civil society, foster cooperation within the community and the regions and eliminate the causes of extreme poverty, fear, oppression, hatred and resentment. On the other hand, the Agenda for Peace acted as an alarm that sounded at the highest levels of the UN itself, namely the Security Council and the General Assembly, to demonstrate that conventional UN Peace Missions - more positive in interstate rather than intrastate conflicts (Branco, 2004: 108-109) - will not be able to respond to new threats to peace and will have to adjust to contemporary conflicts.

Here, of course, we have to point out that the notion of conflict has changed decisively, posing new challenges for those seeking to relieve tensions. Areas of violent conflict have emerged in border regions and at an intrastate or sub-state level, creating true "enclaves" of war (urban or regional) in peaceful spaces (Manwaring, 2005). But it is especially in regions where the state no longer (or not yet) has a monopoly on the legitimate use of force, nor is it capable of fulfilling the most basic governance tasks that this type of conflict breaks out. These regions are often in a phase of reconstruction after long periods of war in which (re-)conciliation efforts have not yet overcome the culture of violence, but also during independence processes following the fall of dictatorial regimes in which the transfer of power has not yet been consolidated or regulated. However, it is important to note that these "new wars" (Creveld, 1991; Duffield, 2001; Kaldor, 2001; Kalyvas et al., 2008; Münkler, 2003) can also be understood as a return to the old forms of violent conflict that have marked societies for thousands of years and which, in fact, have only recently changed, largely from a culture of war that the "euroworld" has imposed (Keegan, 1993; Münkler, 2003). ${ }^{4}$

In any case, the idea of post-conflict peacebuilding already reflects this "new context" (Boutros-Ghali, 1992) in that it points to a whole different approach to peacebuilding, which requires greater involvement not only during the conflict, but also in the moments preceding and following the escalation of violence, integrating in this post-conflict phase the reconstruction of key areas for sustainable and appropriate peace throughout society.

We can observe two orientations of this paradigm shift, one concerning the concept of peace, the other concerning the practice of peace missions, both interconnected and concerned about peace as the possible mission that can be achieved in a medium-term strategy. According to the first guideline, in the Boutros-Ghali statement, peace is

4 The discussion about the "new wars" concept, however interesting, goes beyond the scope of this article. 


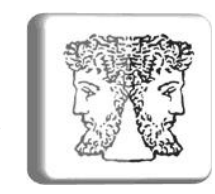

understood as a composite or comprehensive value. Drawing on innovative and critical studies of peace studies, developed by experts such as Johan Galtung (1969) or Dieter Senghaas (1971), peace is conceived not only as the absence of direct violence or war, but above all as the possibility of life without indirect violence (such as political and social repression) and with full participation in free and fair institutions (including forms of education) that generate civil capacities for tolerance, consensus building through pluralistic and competitive debate and conflict resolution. Senghaas' conflict management proposal, called Zivilisierung - which is today a cornerstone of peace studies - seems particularly relevant to us, as it implies an integrated vision of appeasement that is reflected in the political and social coexistence of the communities to be rebuilt in the post-war world. It is worth recalling, briefly, the "civilizational hexagon" model (Senghaas, 1971) developed by this author as part of his ideas on peacebuilding. Thus, peace is essentially seen as a project of civilization that corresponds to a course of individual and collective appeasement ${ }^{5}$. In the theoretical debate, the civilizational hexagon represents, figuratively, the interdependence between six factors considered essential to the possibility of peace. The first factor would be the monopoly of violence. Only this legitimate monopoly (that is, according to precise laws) of state violence, which would require the disarmament of the population and the general prohibition of nonstate-dependent armed groups, could ensure discursive conflict management in the public space, gradually eliminating the use of force as a combat pattern and stimulating argumentative forms in the defence of confronting particular interests. The second factor would underline the imperative of the rule of law, in that the monopoly of state violence presupposing transparent, regulated and controlled mechanisms would not be sufficient. For Senghaas, the whole political architecture of a state committed to peace is based on respect for a constitution that enshrines the division of power, equality before the law and all the other principles that characterize what we understand today as a democratic rule of law state. The third factor draws attention to the control of passions. In an open society, moderation is, as a domestication of impulses, a way of peacefully managing conflict and replacing violence with tolerance. Social and political peace thus presupposes individual competences for self-control and moderation of the passions. Democratic participation emerges as a fourth factor, highlighting not only the importance of political participation, but also thorough learning of democratic rules that require commitment, cooperation and accountability. In the context of modern societies strongly marked by permanent changes and re-adaptations, critical and active collaboration is all the more important. Social justice is the fifth factor in Senghaas' model. Drawing on several examples of states in which serious violent conflicts have arisen, the author highlights the importance of social justice as a political fair play that guarantees equal opportunities and solidarity, enabling trust and hope in the state - values that give rise to the availability of cooperation and peaceful conflict management. Finally, constructive conflict management is outlined as a sixth factor. Following the above factors, regarding the ability to choose nonviolent ways to confront and work conflicts, Senghaas points to a whole culture of peaceful conflict regulation that is already a result of previous conditions or learning. It presupposes habits and good examples, and probably certain characteristics considered as "virtues" (tolerance, moderation, empathy, commitment, respect for social and political rules, willingness to trust, etc.) that facilitate a peaceful coexistence in plural and multicultural societies. This last factor already points to the

5 It should be noted that in applying the concept of "civilization" to peace studies, Senghaas was greatly influenced by the concept of "civilizational process" coined by Norbert Elias (1994). 


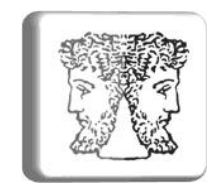

synergy of all the factors that constitute the "hexagon" that would thus allow a culture of peace as an act of moralization, humanization or "civilization".

Returning to the second paradigm shift orientation mentioned above and related to the practice of peacekeeping, it must be said that post-conflict peacebuilding must increase and deepen the maintenance of traditional peace on the ground. It is not intended as a replacement or upgrade for peacekeeping missions, but as a natural complement that can provide a stronger scope for the increasingly complex (and networked) UN work.

Thanks to the impact of an Agenda for Peace, which anticipated many trends in the international political arena, peacekeeping missions have expanded greatly since 1992. A simple analysis of the number and nature of missions, but also of the resources involved (including financing, materials, structures and labour) attests their growing strength. This is particularly true when we consider the UN's ability to involve non-governmental organizations in peace operations and to promote military, paramilitary and civilian cooperation on the ground. For an overview of this work we highlight the universe of UN peacekeeping missions revealing the peace effort: a total of 71 missions, with 14 active missions around the world 6 .

It is also important to mention the UN's willingness to integrate different concepts of peacebuilding that derive not only from a general and universal idea of peace (which is in line with Western culture) and that it intends to impose "from above downwards"- but which stem precisely from the local traditions of undeveloped communities ("bottom up"), as explained, for example, by the works of John Paul Lederach and Janice Jenner (2002) or Wolfgang Dietrich (2005). The authors understand peace as a plural concept, of varied materializations, but always integrating a strong notion of civic participation of the affected population. In this regard, they also warn for the need for each peace operation to be different, depending on pre and post-conflict conditions, the intensity of the conflict and the parties involved, the remaining resources and infrastructure at the end of the escalation of violence, and previous culture and political organization.

All these meanings fed (and later fed themselves) on Boutros-Ghali's Agenda for Peace. Conceptually, this document we are discussing here has opened the door to new reflection on peace and ways and means to implement it on the ground. In this regard, we mention the comprehensive approach developed in NATO operations or, previously, the innovations introduced by Security Council Resolution 1325 on Women, Peace and Security of 31 October 2000.

If we follow the ideas of Michael Doyle and Nicholas Sambanis in their attempt to assess United Nations peacekeeping operations in 2006 - as well as their critical but nonetheless constructive concerns - the overall conclusions are encouraging (Doyle and Sambanis, 2006). Thus, despite their many imperfections, the positive results achieved in just a generation, reaching millions of lives and peoples, reveal these operations as a world stronghold of hope. In this regard, we can conclude that, rather than responding to the Security Council's request to make recommendations to strengthen peacebuilding and peacekeeping in the post-Cold War era, the Agenda for Peace has revitalized all of the

6 As of writing this paper, the field missions are as follows: Haiti (MINUJUSTH), Mali (MINUSMA), Golan (UNDOF), Abyei (UNISFA), India and Pakistan (UNMOGIP), Western Sahara (MINURSO), Democratic Republic of the Congo (MONUSCO), Cyprus (UNFICYP), Kosovo (UNMIK), Middle East (UNTSO), Central African Republic (MINUSCA), Darfur (UNAMID), Lebanon (UNIFIL) and South Sudan (UNMISS). 


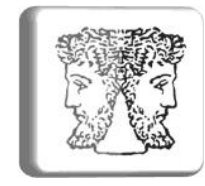

UN's peace work, bringing peacekeeping operations to a broader level with high impact and long-term return.

After the Agenda, other documents and ideas followed and contributed to the updating of UN action in conflicting territories and their missions, namely the Brahimi Report (2000), Capstone Doctrine (2008), or the New Horizon Process (2009).

In an effort to take stock of the then six decades of missions and to present written guidelines for action in complex crises, the United Nation Peacekeeping Operations Principles and Guidelines, also known as the Capstone Doctrine ${ }^{7}$, was published in 2008. In 100 pages, the biggest challenges for UN operations are exposed, as well as the relevance of the ongoing dialogue between the various actors involved in the mission scenarios for adjustments whenever situations require it. Thus, the Capstone Doctrine systematizes seemingly obvious elements, such as the normative framework within which UN peacekeeping operations are supported, while exposing strategic and operational elements, such as deployment and placement phases, or hand over and withdrawal periods.

The New Horizon process, which began in 2009 and aimed at developing a forwardlooking agenda for partnership-based, broad dialogue-based UN peacekeeping operations, benefited from the launch of an internal document entitled $A$ New Partnership Agenda: Charting a New Horizon for UN Peacekeeping ${ }^{8}$, which has been shared with Member States and other partners.

In this set of initiatives leading to as effective as possible peace missions, it is also relevant to mention the UN High-Level Independent Panel on Peace Operations, created in October 2014 during Ban Ki-moon's mandate, composed of 16 individuals (including José Ramos Horta of Timor-Leste, who chaired the meeting). The purpose of this Panel was not only to conduct a comprehensive assessment of peace operations, but also to assess future needs and the role of the UN, following the changes and developments in the conflicts themselves. The report was finalized in June 2015 and was delivered to both the General Assembly and the Security Council, which have attempted to assimilate and accommodate the 166 recommendations covering nine strategic areas.

In order to demonstrate the contribution of the UN Missions and the steps to effect a peacebuilding process, which was already implicit in the (now expanded) peacekeeping operations, we would like to present the case study of East Timor.

\section{The case of East Timor}

The UN has a long-term involvement in East Timor. However, we will narrow the analysis of this work to the period after 1999 and include Indonesia, as the internal situation in this country had significant repercussions on East Timor. The 1997 Asian financial crisis that affected Indonesia, among other countries, was so serious that it involved the intervention of the International Monetary Fund with a $\$ 11.4$ billion aid package for a three-year period (International Monetary Fund, 2000).

\footnotetext{
7 United Nations (2008). United Nation Peacekeeping Operations - Principles and Guidelines, Department of Peacekeeping Operations and Department of Field Support, New York.

8 United Nations (2009). A New Partnership Agenda: Charting a New Horizon for UN Peacekeeping, Department of Peacekeeping Operations and Department of Field Support, New York.
} 


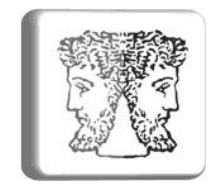

The internal situation worsened and General Shuarto left the scene after three decades in power, giving way in 1998 to a new President, General Habibie, who embarked on a set of political reforms, including a change of attitude regarding Timor. Indeed, on 5 May 1999, an agreement was reached in New York between Portugal and Indonesia with a view to (i) holding a popular consultation with the Timorese people under the aegis of the UN, and (ii) establishing Indonesia's responsibility for peace and safety in East Timor, to ensure consultation in a peaceful environment free from pressure or intimidation. However, even before the popular consultation, there were episodes of great violence, codenamed Operasi Sapu Jagad, deliberately led by militias of the East Timorese and Indonesian military of the TNI (Tentarra Nasional Indonesia/Indonesian Armed Forces).

The UN has kept a close eye on developments, and in order for this consultation to take place without interference, the Security Council approved the establishment of a mission to organize and conduct the process of consultation with the population in East Timor, UNAMET (United Nations Mission East Timor) through Resolution 1246 of 11 June 1999 and with a mandate from June to October 1999. The popular consultation took place on 30 August of that same year and had significant independence-friendly results $(78.5 \%$ of the votes), which surprised the Indonesian power (which considered that the option of special autonomy within Indonesia would be the most voted) and which led to an unprecedented wave of violence by the integrationist militias.

As UNAMET was a political mission and the occurrence of violence multiplied, the Security Council, through Resolution 1264 of 15 September 1999, created an international force, the International Force in East Timor (INTERFET), to restore the law and order in the country, to protect and support UNAMET and to facilitate humanitarian assistance. On 20 September, INTERFET, under Australian command and with Indonesian consent, started its command in Dili with a military force of approximately 7,500 men from 12 countries.

An important step in the construction of this new country was taken by Indonesia when it revoked the annexation of the 27th Province, East Timor, on 19 October 1999. A few days later, on 25 October, the Security Council established, by Resolution 1272, the UNTAET (United Nations Transitional Administration in East Timor) as a multidimensional peacekeeping operation, whose mandate ranged from October 1999 to May 2002. The central objective of peacekeeping operations was to create conditions for the stability of a country, in such a way that it was possible, in a peaceful environment, to invest in human resources training and institutional development, thus contributing to the legitimacy of the (new) state. Indeed, UNTAET was active on three fronts: a transitional UN administration of East Timorese territory, with powers to exercise all legislative and executive functions, including the administration of justice and public order with the police forces; security functions and maintenance of military order; and the coordination of humanitarian assistance.

East Timor became an independent country on 20 May 2002, when UNTAET was replaced by UNMISET ((The United Nations Mission of Support in East Timor) by Resolution 1410 of 17 May 2002. This new peacekeeping mission had an initial mandate of one year and was committed to ensuring the security and stability of East Timor, notably in assisting administrative structures critical to the political viability and stability of the country; supporting public security and police development; and maintaining East Timor's external security. UNMISET has had its mandate renewed until 20 May 2005 as a means of securing and consolidating the achievements of UNTAET and until the Timorese authorities assumed their responsibilities autonomously. 
In May 2005, with the end of UNMISET's term of office, a political mission, called the United Nations Office in Timor-Leste (UNOTIL), was created to assist in the development of basic Timorese state institutions, including police forces, and to provide training in democratic governance and human rights. With an expected duration of one year (until May 2006), the UNOTIL delegation was on the ground until August of that year due to the worsening of the political, humanitarian and security situation. The conditions worsened to the extent that on 11 June 2006, the country's highest political authorities, namely the President of the Republic, the President of Parliament and the Prime Minister, sent a letter to the UN Secretary-General requesting him to propose to the Security Council the establishment of a United Nations police force in East Timor to maintain order until the reorganization of the national police. Indeed, the Secretary-General recommended a multidimensional and integrated UN mission to support the Timorese government in various aspects, namely national reconciliation, electoral processes for president and parliament, security and institutional capacity building in the region, and monitoring the promotion and protection of human rights.

The last United Nations peacekeeping mission in East Timor, the United Nations Integrated Mission in Timor-Leste (UNMIT), was established by Resolution 1704 of 25 August 2006 and had its mandate extended until 31 December 2012. During this period, it was important to consolidate what had been achieved and to ensure stability, democratic governance and political dialogue between the various actors of Timorese society for a process of national reconciliation and solid national cohesion. This mission was ground-breaking and consisted of the creation of a joint plan between the government and UNMIT (Joint Transition Plan) outlining 129 activities that met the priorities and objectives for the transitional period from September 2011 to the end of the UNMIT mandate in December 2012.

Table 1 summarizes the missions referred to in the paragraphs above, as well as their mandates.

Table 1. UN Missions in East Timor

\begin{tabular}{|c|c|}
\hline Mission & Mandate \\
\hline $\begin{array}{l}\text { UNAMET } \\
\text { United Nations } \\
\text { Mission in East } \\
\text { Timor }\end{array}$ & $\begin{array}{l}\text { - Security Council Resolution } 1246 \text { of } 11 \text { June } 1999 \text { established UNAMET until } 31 \\
\text { August } 1999 \text { to organize and conduct the popular consultation scheduled for } 8 \\
\text { August } 1999 \text {. } \\
\text { - Resolution } 1257 \text { extended the mission to } 30 \text { September } 1999 \text {. }\end{array}$ \\
\hline $\begin{array}{c}\text { UNTAET } \\
\text { United Nations } \\
\text { Transitional } \\
\text { Administration } \\
\text { in East Timor }\end{array}$ & $\begin{array}{l}\text { - Security Council Resolution } 1271 \text { of } 25 \text { October } 1999 \text { established UNTAET with } \\
\text { the responsibility to administer East Timor, having executive and legislative } \\
\text { authority, including the administration of justice. } \\
\text { - UNTAET was in operation from } 25 \text { October } 1999 \text { to } 20 \text { May } 2002 \text {. } \\
\text { - Total human resources: } 9,150 \text { military personnel; } 1,640 \text { police officers; and more } \\
\text { than } 2,000 \text { civilians (international and local). } \\
\text { - There were a total of } 17 \text { human casualties ( } 15 \text { military personnel, one police } \\
\text { officer and one military observer) }\end{array}$ \\
\hline $\begin{array}{l}\text { UNMISET } \\
\text { The United } \\
\text { Nations } \\
\text { Mission of } \\
\text { Support in } \\
\text { East Timor }\end{array}$ & $\begin{array}{l}\text { - Security Council resolution of } 17 \text { May established UNMISET with the mission of } \\
\text { providing assistance in administrative areas vital to East Timor's political viability } \\
\text { and stability, as well as security. } \\
\text { - The mandate of UNMISET was effective form } 20 \text { May } 2002 \text { to } 20 \text { May } 2005 \text {. } \\
\text { - Initially, the human resources dimension foresaw about 5,000 military personnel; } \\
1,250 \text { police officers; about } 1800 \text { civilians (including international staff, local staff } \\
\text { and volunteers). } \\
\text { - In terms of fatalities of these human resources, there were } 21 \text { casualties. }\end{array}$ \\
\hline
\end{tabular}




\begin{tabular}{|c|c|}
\hline $\begin{array}{c}\text { UNOTIL } \\
\text { United Nations } \\
\text { Office in } \\
\text { Timor-Leste }\end{array}$ & $\begin{array}{l}\text { - Security Council Resolution } 1599 \text { of } 28 \text { April } 2005 \text { established UNOTIL with a } \\
\text { mandate of one year (until } 20 \text { May 2006). It consisted of a special political mission } \\
\text { to accompany and support the development of state institutions in the areas of } \\
\text { police training, border patrol, military advice, human rights, and democratic } \\
\text { governance. }\end{array}$ \\
\hline $\begin{array}{l}\text { UNMIT } \\
\text { United Nations } \\
\text { Integrated } \\
\text { Mission in } \\
\text { Timor-Leste }\end{array}$ & $\begin{array}{l}\text { - Security Council Resolution } 1704 \text { of } 25 \text { August } 2006 \text { established UNMIT with an } \\
\text { initial term of six months, renewable for equal periods, with a sphere of action in } \\
\text { support of government and institutions relevant to the consolidation of stability, } \\
\text { strengthening the culture of democratic governance and facilitating political } \\
\text { dialogue between Timorese actors in their efforts for national reconciliation and } \\
\text { social cohesion, as well as supporting the } 2007 \text { (presidential and parliamentary) } \\
\text { electoral processes. } \\
\text { - The authorized force comprised } 1,608 \text { police officers, } 34 \text { military liaison officers } \\
\text { and civilians. Since } 2006,5,119 \text { police officers, } 262 \text { military personnel and around } \\
3,000 \text { civilians and volunteers have taken over the mission. } \\
\text { - There were a total of } 17 \text { casualties ( } 9 \text { police officers, } 4 \text { local civilians and } 4 \\
\text { international civilians). }\end{array}$ \\
\hline
\end{tabular}

Source: Authors' own based on the aforementioned Resolutions.

The efforts made by the UN and summarized here constitute, in our view, a very important factor not only for the pacification of East Timor, but also for its development and gradual but nevertheless increasing prosperity. Different reports and international rankings prove the improvement of living conditions, as well as an increase of freedom. The Global Peace Index places East Timor at the 53rd place (out of 163) in 2018. According to the Freedom House's assessment of the "state of freedom" in each country, East Timor has improved its position from "partially free" to "free" last year, which seems to us a very positive development.

\section{Conclusion}

The presence of the UN in East Timor was a set of essential elements to lead the country to a peaceful environment, namely commitment and monitoring of situations. This small country that was asserting itself in the international community was testament to the success of the United Nations, which contributed substantially to the rehabilitation of public infrastructure, the restoration of social harmony, administrative and community structures, and the establishment of democratic governance. In addition, the Timorese case virtually integrates all types of operations of the Agenda for Peace, inasmuch as the intervention started with peace enforcement, under Chapter 7, with INTERFET; it was followed by a multidimensional peacekeeping/peacebuilding operation ${ }^{9}$; and culminated in the country's own appropriation of competences for its normal and expected development. Indeed, there has been a transformation of the conflict, typical of peace operations, into a structured product of various interventions undertaken by official and unofficial actors working at all levels of society - and with society. During the UN missions, the integrated military component made a decisive contribution to global stability and a

9 Peacebuilding, either post-violence, post-settlement (comprehensive settlement) or as an effort to prevent reemergence from conflict, depends on the ability to transform the conflicting situation of potential/current mass violence into a peaceful and cooperative relationship capable of promoting reconciliation and reconstruction and sustainable development over time. Peacekeeping is a conflict management tool to contain violence, while peacebuilding is the means to establish viable and inclusive democratic governance in a post-conflict society, usually through free and fair elections, independent legislative and judicial functions, responsible transparency and governance, access to political and economic opportunities, and equitable sharing of wealth. 
secure environment within the territory, particularly in border areas. However, in addition to the indispensable presence of the military, which ensures the security environment and is fundamental to the development and well-being of the population, the post-conflict peace building operations enabled thinking and finding broader (and more effective) responses to the challenges that the new conflicts pose not just for a community but for an entire region. It will therefore be in the ability of the UN to adjust to the changing conflicts in a globalized world, and in its courage to continue and extend its missions, that the key to win peace again and day after day, lies.

\section{References}

Boutros-Ghali, Boutros (1996) "Challenges of Preventive Diplomacy: The Role of the ONU and Its Secretary-General", in Cahill, Kevin M. (ed.), Stopping Wars before they Start: Preventive Diplomacy, New York: Basic Books.

Branco, Carlos M. (2004). "A ONU e o processo de resolução de conflitos: Potencialidades e limitações", Relações Internacionais, no 4: 105-125.

Security Council, Resolution 1704 (2006). United Nations Organization. [8 October 2018]. Available at: https://undocs.org/S/RES/1704(2006).

Security Council, Resolution 1257 (1999). United Nations Organization. [8 October 2018]. Available

at: http://www.un.org/ga/search/view_doc.asp?symbol=S/RES/1257(1999)

Security Council, Resolution 1246 (1999. United Nations. [8 October 2018]. Available at: http://unscr.com/files/1999/01246.pdf

Creveld, Martin Van (1991). The Transformation of War, New York: Simon \& Schuster.

Dietrich, Wolfgang (1997). A Call for Many Peaces, Peace Center Burg Schlaining.

Doyle, Michael e Sambanis, Nicholas. (2006). Making War \& Building Peace. United Nations Peace Operations. Princeton: Princeton University Press.

Duffield, Mark (2001), Global Governance and the New Wars. London: Zed Books.

Elias, Norbert (1994). The Civilizing Process. Malden: Blackwell

International Monetary Fund (2000). Recovery from the Asian Crisis and the Role of the IMF. [12 October 2018]. Available at: https://www.imf.org/external/np/exr/ib/2000/062300.htm\#box3

Kaldor, Mary (2001). New and Old Wars: Organized Violence in a Global Era, Stanford: Stanford University Press.

Kalyvas, Stathis N., Ian Saphiro et. al. (ed.) (2008). Order, Conflict \& Violence, Cambridge: Cambridge University Press.

Keegan, John (1993). A History of Warfare, Vintage.

Manwaring, Max G. (2005). "Street Gangs: The New Urban Insurgency", Strategic Studies Institute, U.S. Army War College, (http://www.carlisle.army.mil/ssi/pdffiles/ PUB597.pdf)

Münkler, Herfried (2005). The New Wars, London: Polity. 
Lederach, John Paul and Jenner, Janice Moomaw (2002). A Handbook of International Peacebuilding: Into The Eye Of The Storm, San Francisco: Jossey-Bass.

United Nations (2015). Report of the High-Level Independent Panel on United Nations Peace Operations, UN Doc. A/70/95-S/2015/446, 17 June 2015.

United Nations (2009). A New Partnership Agenda: Charting a New Horizon for UN Peacekeeping, Department of Peacekeeping Operations and Department of Field Support, New York.

United Nations (2008). United Nation Peacekeeping Operations - Principles and Guidelines, Department of Peacekeeping Operations and Department of Field Support, New York.

United Nations (1992). An Agenda for Peace. Preventive Diplomacy, Peacemaking and Peace-Keeping. [8 October 2018]. Available at: http://www.un-documents.net/a47277.htm

United Nations Peacekeeping, United Nations Integrated Mission in Timor Leste. [9 October 2018]. Available at:

https://peacekeeping.un.org/mission/past/unmit/index.shtml

United Nations Peacekeeping, United Nations Integrated Mission in Timor-Leste completes its mandate - Fact Sheet. [9 October 2018]. Available at:

https://peacekeeping.un.org/sites/default/files/past/unmit/documents/unmit_fact_shee t_11dec2012_2.pdf

United Nations Peacekeeping, United Nations Mission of Support in East Timor. [10 October 2018]. Available at: https://peacekeeping.un.org/mission/past/unmiset/

United Nations Peacekeeping, United Nations Transitional Administration in East Timor. [10 October 2018]. Available at: https://peacekeeping.un.org/mission/past/etimor/etimor.htm

United Nations Peacekeeping, East Timor - UNTAET Fact and figures. [9 October 2018]. Available at: https://peacekeeping.un.org/mission/past/etimor/UntaetF.htm 


\title{
OPPORTUNITIES FOR CONFLICT PREVENTION. LESSONS FROM THE ECONOMIC COMMUNITY OF WEST AFRICAN STATES (ECOWAS)
}

\author{
Jara Cuadrado \\ jaracb.4488@gmail.com \\ PhD in International Security (Universidad Nacional de Educación a Distancia). Postdoctoral \\ Researcher at Instituto Universitario General Gutiérrez Mellado (Spain). She is integrated \\ Researcher at OBSERVARE, Observatory of Foreign Relations, Universidade Autónoma de Lisboa.
}

\section{Abstract}

Conflict prevention has become an important doctrine within conflict management policies in international and regional organizations, especially since the end of the Cold War. There has been an evolution in the last three decades in the context of peace and security that has made conflict prevention gains relevance. In the current context, with the arrival of António Guterres to the Secretary General of the United Nations (UN), conflict prevention doctrine could be encouraged, since he has pointed out that it should be the priority of the organization.

Conflict prevention offers several advantages to face crisis contexts, since it works on avoiding violence situations escalating towards armed conflicts and helping to control the spread of security threats. By using preventive measures, the structural causes of conflicts can be dealt with in the most durable and efficient manner since the final goal of preventive actions is to transform actually or potentially violent conflict into non-violent processes of social and political change.

While conflict prevention has gained greater importance, another trend has been promoted; security regionalization. Since the mid-nineties, there has been a transition in international peacekeeping missions, aimed to warrant peace and security all over the world that has focused on regional actors. This practice has been particularly welcomed in Africa.

Both trends -conflict prevention and security regionalization- will be the object of study in this article, using as a practical scenario the region of West Africa. It is a geographic area where a series of cross-border threats are concentrated, hence becoming a zone of international concern. Moreover, the experience on conflict prevention of the regional organization, the Economic Community of West African States (ECOWAS) is interesting. Indeed, ECOWAS has carried out a significant activity regarding preventive diplomacy and mediation in conflicts.

Thus, the objectives of this research are: (1) to study the evolution of conflict prevention doctrine; (2) to assess the link between conflict prevention policies and security regionalization; and (3) to use the case of ECOWAS as an illustration, since the organization is at the forefront of conflict prevention iniciatives in the African continent.

\section{Keywords}

Conflict prevention, diplomacy, regionalization of security, West Africa, ECOWAS.

\section{How to cite this article}

Cuadrado, Jara (2019). "Opportunities for conflict prevention. Lessons from the Economic Community of West African States (ECOWAS)". JANUS.NET e-journal of International Relations, Vol. 10, N.0 2, November 2019-April 2020. Consulted [online] on the date of the last visit, https://doi.org/10.26619/1647-7251.10.2.2 


\title{
OPPORTUNITIES FOR CONFLICT PREVENTION. LESSONS FROM THE ECONOMIC COMMUNITY OF WEST AFRICAN STATES (ECOWAS) ${ }^{1}$
}

\author{
Jara Cuadrado
}

\section{Introduction}

The dynamics of the armed conflicts that have taken place since the decade of the nineties have forced the development of different measures capable of addressing the challenges that arise in the international scenario. Thus, the advances made in conflict management respond to the changes in the normative and conceptual framework, marked by the need to solve a series of increasingly complex contexts.

In this sense, policies aiming at prevention are an indispensable tool for the management of armed conflicts, since they can help to control the spread of security threats. This set of measures works on preventing situations of violence and insecurity that can lead to an armed conflict as well as transforming those situations in which there are factors that threaten the safety of people and turning them into peaceful and stable processes (García Izquierdo, 2002).

Despite the advantages offered by this type of measures, as it is the "most pragmatic and cost-effective option" (United Nations, 2015, p.4), it has not received much attention, overshadowed by others measures that focus on more direct actions, such as peacekeeping missions. However, this doctrine could acquire more interest in the future from the UN, especially since the arrival of the new Secretary General, António Guterres, on 1 January 2017, who proposes to return to the origins of the organization, which was founded with the objective of taking "effective collective measures for the prevention and removal of threats to the peace" (Charter of the United Nations, 1945, article 1).

In this context, the article tries to emphasize, firstly, the need to assess prevention as one of the priorities in the field of security and peace, since it offers important advantages for the management of situations of violence and conflict. Secondly, it also aims to highlight an aspect considered essential for the progress of prevention policies: the promotion of the regionalization of security. In the nineties, with the end of the Cold War, theories about regional security began to emerge, since new actors appeared in the international scene that presented a "challenge to international relations (IR) theory" and

Special issue of articles presented at the 1st International Conference on Conflict Resolution and Peace Studies that took place at UAL on the $29^{\text {th }}$ and $30^{\text {th }}$ of November 2018. 

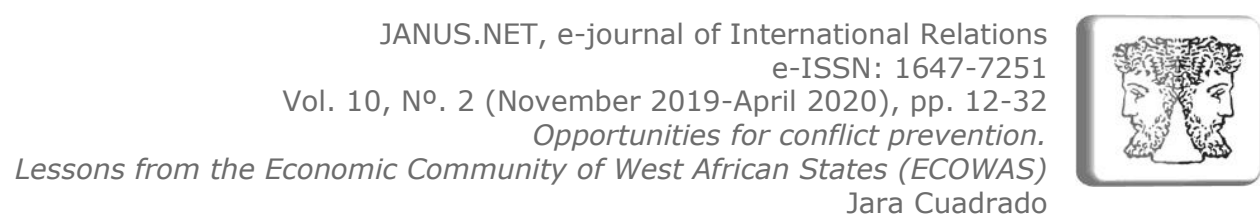

that "revolves around the autonomy of a regional level of analysis between the state and the globe" (Kelly, 2007, p.197).

Thus, this article tries to answer the question of wether regional actors can play a fundamental role in the prevention of conflicts within their regional security complexes (Buzan, Wæver \& Wilde, 1998) and how they do it. For this purpose, the case of ECOWAS is analysed, as a regional organization with experience in conflict prevention.

The paper is structured in four sections. Firstly, it defines the concept of conflict prevention and examines its evolution in the last three decades. Secondly, the phenomenon of security regionalization is studied, with special attention to the African continent. Thirdly, the article will focus on the case of ECOWAS and its experience in conflict prevention. Finally, some of the conclusions of the research on conflict prevention are presented.

\section{The (re)emergence of a culture of prevention?}

\section{What is conflict prevention?}

In this article, the concept of conflict prevention is understood as the set of measures that are destined to: avoid the triggering of violence; avoid an active conflict worsens; and that works over contexts before tensions arise. It pursues, as the ultimate goal, the transformation of "real or potentially violent conflicts into peaceful processes of political and social change" (Ramsbotham, Miall \& Woodhouse, 2011, p.113).

Although conflict prevention is especially applied at the beginning of the conflict, when tensions and disputes are escalating into violent conflict (graphic 1), it must be present throughout the crisis. The efforts should be focus not only on trying to contain or stop a situation of armed violence, but also on resolving the factors that lead to that situation.

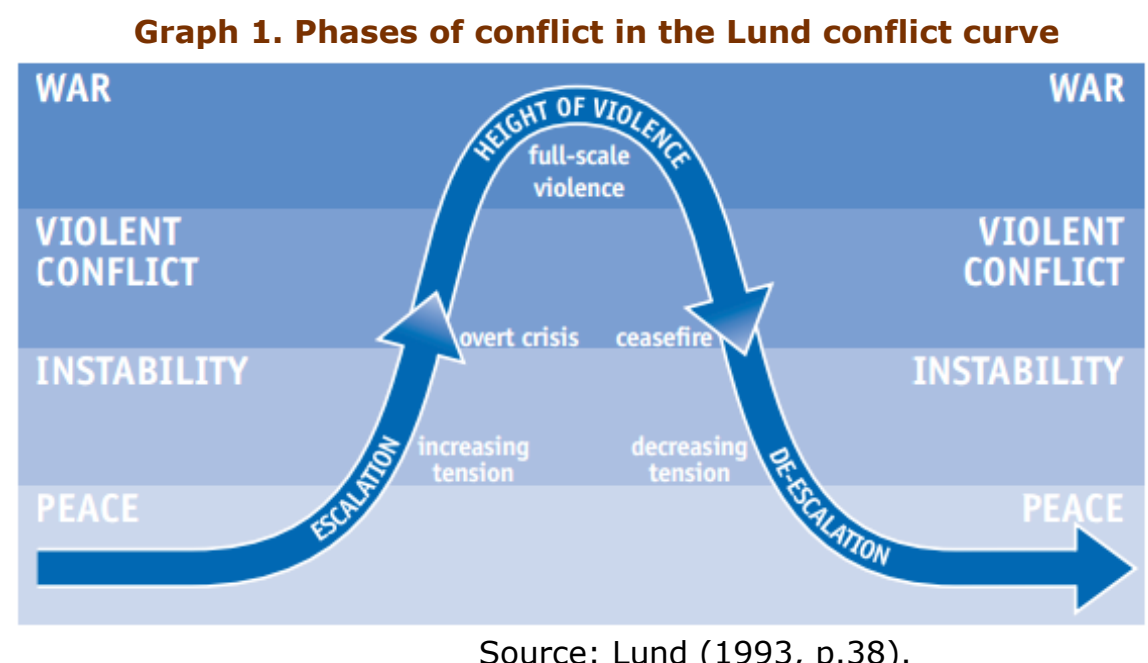

Preventive policies are developed from different areas (from the community, from the local level, from national governments or from international spheres), so there is a wide range of possibilities to used them. From tools such as preventive diplomacy, good offices and mediation as preventive instruments in situations of war, it has been an evolution 

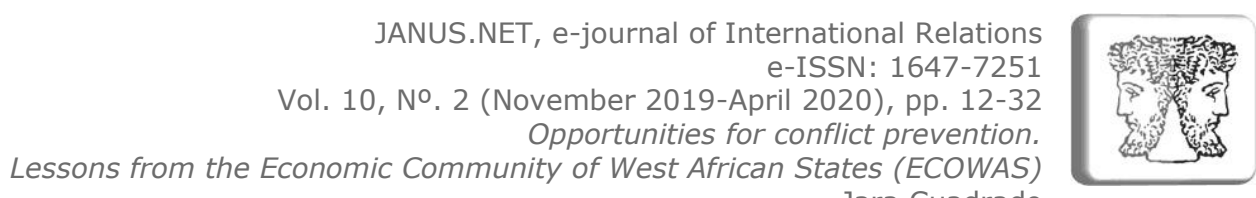
Jara Cuadrado

into another type of more complete actions, adapted to the complexity of the current contexts.

This is how they were classified ${ }^{2}$ in the Final Report of the Carnegie Commission on Preventing Deadly Conflicts, entitled Preventing Deadly Conflict (Carnegie Corporation of New York, 1997) -a document of reference-, which distinguished between:

Operational measures, which are launched in the face of an impending crisis. They act against risk factors and are direct and short-term measures.

Structural measures, which address the sources of conflicts, the underlying causes, and involve broad and long-term change processes. These are measures for economic, social and political stability.

This is the categorization used by most studies, but the concept of conflict prevention as well as its scope of action have generated an intense and interesting debate -which is not the object of study of this article-, giving rise to different interpretations on what is and is not the prevention of conflicts (Menkhaus, 2004; Lund, 2009, p.289; Igaripé Institute, 2018).

Preventive measures, both operational and structural, represent an interesting field of action in the management of troubled contexts and they can be employed simultaneously throughout the conflict cycle. This is the case of preventive diplomacy, which took up an important place in the UN's agenda in the nineties. This concept is living a resurgence in the present, (United Nations, 2017a). Preventive diplomacy is very useful at the first stage of the conflict cycle, since it works before violence erupts through good offices and negotiations, when a third party assists to parties in conflict to solve their problems. In these cases, the role played by highly respected personalities in the international political sphere is key. For instance, one of the main organs within ECOWAS peace and security architecture is the Council of the Wise, made up of eminent personalities who act as mediators (El Abdellaoui, 2009). Preventive diplomacy has been a very common practice in conflictual electoral contexts -with more or less success-; such as in some cases in West Africa, such as Côte d'Ivoire (2011), Senegal (2012), Nigeria (2015) or Gambia (2017). Preventive diplomacy has also been used after coups d'États, like in Mali 2012.

As a kind of coercitive diplomatic measure, economic sanctions -authorized by the Article 41 of the UN Charter- are used when tensions have arisen and there is an overt crisis. They are used when mediation do not work and before considering a military intervention. They have been used at different types of conflicts, from Liberia, to Sierra Leone, Côte d'Ivoire, Guinea-Bissau or Mali.

When conflict is imminent, preventive deployment becomes a useful tool as a dissuasive measure. There has been much discussion regarding the maintenance of a rapiddeployment peacekeeping force in different international and regional organizations (Darkwa, 2017; Lotze, 2015; Rappa, 2017). In West Africa there is the ECOWAS Standby Force that it is part of the African Union Standby Force (ASF), which is "a multidisciplinary, continental peacekeeping force comprised of military, police and civilian components, which are on standby in their regions of origin and available to the African

2 This classification is then adopted by other institutions like the UN, the European Union (EU) or the African Union (AU). 

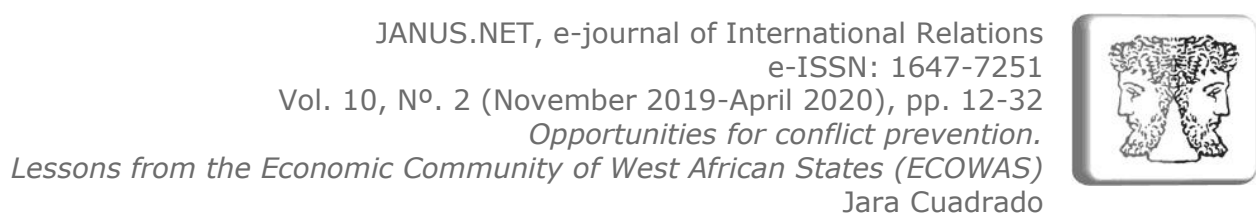

Union for deployment in times of crisis" (Institute for Security Studies, 2015). This option was used in Gambia, for example, through the deployment of the Economic Community of West African States Military Intervention in Gambia (ECOMIG) to enforce the election results in 2017, with a positive impact (Hartmann, 2017).

This type of measures, applied before the armed conflict breaks out, are operational and direct; however, it is even more important to develop structural measures at the first signs of tensions as well as throughout the entire cycle of the conflict. Actions focus on the underlying factors of tensions are critical in contexts of political violence. These are measures aimed at economic, political and social stability, whose development entails longer-term plans than operational measures, and they focus on aspects like governance, development and human rights (De Carvalho, 2017). However, in this article the focus is on the operational measures.

\section{Evolution and future}

Until recently, preventive policies have been relegated to a second place on the agendas of international and regional organizations, where attention has been directed predominantly towards the contexts of active civil wars as well as to the activities of postconflict reconstruction.

However, since the end of the Cold War, conflict prevention has begun gaining a greater role in the conflict management policies of international and regional organizations (Cuadrado, 2018; Ramsbotham, Miall \& Woodhouse, 2011), as evidenced by the more often reference to it in the official documents ${ }^{3}$. Thus, regional organizations -such as ECOWAS- have made conflict prevention one of their priorities.

Studies on the prevention of armed conflicts have proliferated in the last three decades, marked by the failure of the UN in the nineties to anticipate and respond effectively to contexts such as Somalia, Bosnia or Rwanda (United Nations, 2014a). These humanitarian catastrophes showed the importance of prevention and the need to overcome a culture of reaction, where actions take place after the violence has broken out, which has featured the history of the UN (Dorn \& Matloff, 2000).

Since the former Secretary-General of the UN, Kofi Annan, adopted the concept of 'culture of prevention' in his report entitled Prevention of Armed Conflict, of June 2001, where he already talked about passing 'culture of reaction' and advancing to a 'culture of prevention', there has been an evolution. Conflict prevention has lived different stages, ups and downs.

Currently, it can be said that there is a new enthusiasm for prevention. In the agenda of the present Secretary General, António Guterres, prevention occupies a high priority (Leone, 2017). As the Secretary General has reflected, "the world spends much more

\footnotetext{
3 For example, the Report of the Secretary General entitled Armed Conflict Prevention of 2001, where a classification of the type of preventive measures is made, Security Council Resolution 1366 of August 30, 2001 on the role of the Council in the prevention of armed conflicts, the Report of the General Assembly (A / RES / $57 / 337$ ) of July 18,2003 on the prevention of armed conflicts, or the Secretary-General's Report on the implementation of the Security Council resolution 1625 (2005) on the prevention of conflicts, in particular in Africa, of 2008.
} 

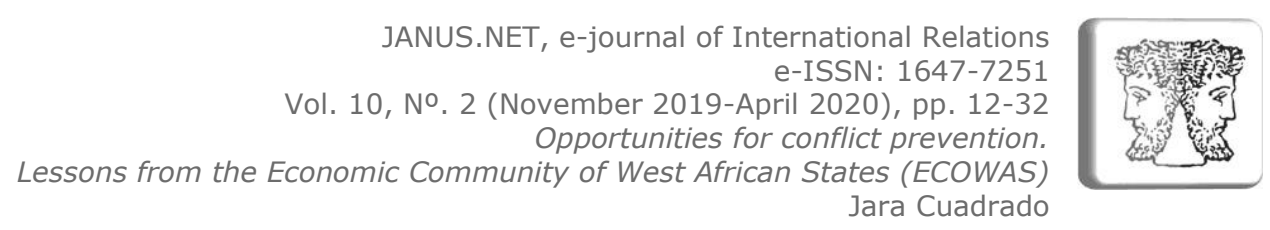

energy and resources managing crises than preventing them. Thus the UN must uphold a strategic commitment to a 'culture of prevention'"' (United Nations, 2016, p.3).

In spite of this new enthusiasm that seems to exist within the UN for the prevention of conflicts, there are important barriers that can hinder its success and that must be overcome in the future. The reality is that "the Security Council's agenda is already overburdened by managing ongoing conflicts [which] makes [...] difficult [...] to devote time to crises bubbling below the surface" (Roberts, 2017).

Traditionally, the attention has been put on the management of immediate crises and large-scale conflicts (United Nations, 2018). The efforts that active conflicts require in all senses decreases the possibilities of focusing on prevention, even though these efforts could be reduced if they were "able to focus on prevention" (Roberts, 2017).

The tipycal dynamics of international power relations can also influence the success or failure of prevention. Thus, for example, it is important to take into account the reluctance of some countries concerning the limits of sovereignty or that the Council Security's "interest in acting in a preventive capacity [is] already limited in cases when a powerful member was involved in a looming conflict" (Roberts, 2017). Other aspects have to do with "the difficulty in [...] demonstrating that a given action resulted in conflict not taking place" (United Nations, 2018, p.1).

Thus, as Stephanie Sugars (2017) points out, so that the enthusiasm that Guterres is demonstrating translates into success, it is necessary "a fundamental break with the UN's current approach, not to mention sizeable reforms to address the body's its sluggish response time to conflicts [or] its burgeoning bureaucracy".

Added to this, it is the lack of political will to deploy measures that respond early to alerts. Several authors (Stanton, 2005; Wulf \& Debiel, 2009; Evans, 2016) have indicated that political will is the key, either for the time to develop an accurate analysis, for not being aware of the type of skills needed to handle the problem, or for the lack of interest in specific topics or regions.

These obstacles, which make it difficult to carry out measures with a preventive effect, could be overcome or reduced, to some extent, if the prevention of conflicts is further promoted by regional organizations.

\section{Regionalization as an opportunity: taking advantage of local actors to promote prevention}

The regionalization of security, a trend that has gained importance in the last three decades (Berman, 2002; Francis, 2006; Moller, 2009), could help to encourage conflict prevention. It is increasingly common for regional bodies, as ECOWAS, to assume the management of their peace and security problems, through the development of new policies and mechanisms (Tavares, 2009). The region of West Africa encompasses a series of security threats that can have a destabilization effect throughout the region as it occurs with terrorism and organized crime, or with climate change and violence related to resource scarcity. This produces a security interdependence, since national security concerns of West African states are very similar and are so close that they can not be addressed indpendently (Persson, 2012). Thus, regional problems are managed 
JANUS.NET, e-journal of International Relations e-ISSN: $1647-7251$ Vol. 10, No. 2 (November 2019-April 2020), pp. 12-32 Opportunities for conflict prevention.

from a regional co-operation (Buzan, Waever \& Wilder, 2003) under the ECOWAS architecture.

The involvement of regional organizations in security issues has significant advantages, such as a better knowledge of the context and of the causes of conflict. They are actors who know the terrain better so they understand the situation from another perspective and have a direct interest in the repercussions and solutions of the conflict. Moreover, "regional political actors [...] have both greater legitimacy and a much greater political stake in taking a diplomatic lead" (Gowan, 2017, p.6).

Consequently, regional and local actors, with the support of the international community, play a leading role in conflict prevention. As Guterres has outlined, regional organizations are essential actors in conflict prevention and resolution, in peace operations and promotion of development and human rights (United Nations, 2016, p.4).

However, this option is not always the best. One of the problem is the competition between some regional actors that can affect prevention success. For instance, the traditional rivalry of Nigeria and South Africa "have prevented consensus within the AU on key preventive diplomacy efforts" (Hara, 2011). The leadership role developed by Nigeria has awakened mistrust in other ECOWAS members at different conflictual situations, like the civil wars of Liberia and Sierra Leone (Adebajo, 2002), which has made difficult to come to an agreement within the regional organization.

Furthermore, personal ties between political leaders determinate the position that governments adopt in the face of a crisis, therefore there is not impartiality. This has occured in several ocassions within ECOWAS. While overwhelming measures were taken after the coups d'État in Guinea in 2008 or in the Gambian context in 2017, a weaker attitude has been shown during the recent crisis in Togo (RFI Afrique, 2017) ${ }^{4}$. Different reactions are explained by the individual interests of each Member State, which have diverse strategic views that hinder a common decision-making and effective responses. Thus, this clash of interests can be detrimental to the advance of the empowerment of regional organizations in sensitive issues like security.

Moreover, regional actors like ECOWAS have shortage of material, financial and human resources, showing a dependence on external actors that limits the success of security regionalization. In this sense, the African continent is one of the priorities for the UN. The organization is aware of the need to cooperate with Africa's regional organizations for the promotion of preventive measures; this cooperation is essential to overcome the lack of resources. Accordingly, the UN "reaffirms its intention to consider further steps to promote closer and more operational cooperation between the United Nations and regional and subregional organizations in the fields of early warning, conflict prevention, peacekeeping and peacebuilding" (United Nations, 2014b). In 2002 the Ad hoc Working Group on Conflict Prevention and Resolution in Africa was created (United Nations, 2002). More recently, it was established a Cluster on Conflict Prevention and Crisis Management by the UN Office for the African Union (UNOAU), which is a strategic partnership in conflict prevention and mediation, working "throughout all phases of the conflict cycle", between the UN and the AU (United Nations Office to the African Union, n.d.).

Cooperation between different actors in the field of peace and security has been a trend that has evolved and grown. That implies sometines an "institutional overlap of actors"

${ }^{4}$ These cases will be addresseed in a later section. 

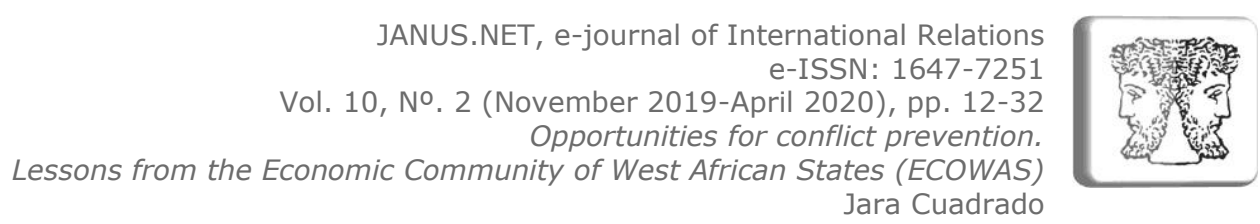

which "operate and intervene in the same geographical area [...] in the same crisis at the same time or replacing each other" (Sousa, 2017, p.572). Thus, a lack of alignment is frequent as well as a tendency for divergence, contradictions and duplicity of efforts and resources. Africa has been setting of disputes between the UN, the $A U$, and the regional organizations (Nathan, 2017, p.151).

Operations launched by regional organizations need authorization by the Security Council prior to deployment (UN Charter, Chapter VIII, Art. 53), causing in many ocassions "disagreements [...] at various levels of decision-making" between the UN and the AU (Desmidt \& Hauck, 2017, p.15), but also with ECOWAS, which does "not explicitly acknowledge the supremacy of the UNSC [the United Nations Security Council] if it comes to peace and security" (Jetschke \& Schlipphak, 2019, p.4). As Williams has highlighted (2017, p.129), it is necessary that "the UN develops appropriate support mechanisms" for regional organizations in Africa, especially because of the lack of "predictable, sustainable, and flexible funding" they have (Williams, 2017, p.129).

At the same time, divergence appears between the $A U$ and the regional organizations, like ECOWAS, where a "lack of clarity on subsidiarity and division of labor [...] often lead to ad-hoc and pragmatic solutions" (Desmidt, 2019, p.2), affecting the deployment of preventive measures. From the AU, the concept of primacy is standed up (Desmidt, 2019, p.4), however, the principle of subsidiarity "states that responses to conflict should be formulated by organizations with closest proximity" (Desmidt, 2019, p.12); thus, as Nathan (2017, p.157) has highlighted, policy documents "are ambiguous or contradictory" when tackling crisis management.

On the whole, although security regionalization offers a great opportunity to encourage conflict prevention policies, there is still a dependence on external actors. This has caused an overlap and confusion between all stakeholders that intervene in a crisis, difficulting the capacity of action to intervene or act preventively.

\section{The experience of ECOWAS in conflict prevention}

The West African region is a great example to analyse these issues, since it has experienced an interesting process of security regionalization and has also lived interventions from different actors.

This region has attracted a great interest and concern, due to the number of conflicts that have been in the area. For this reason, in 2000, a regional conflict resolution office was established in Senegal, currently the United Nations Office for West Africa and the Sahel (UNOWAS ${ }^{5}$ ), whose objectives are to develop regional diplomacy to manage political instability within the region (Gowan, 2017, p.9). UNOWAS has developed activities coordinated with ECOWAS, specially in the field of conflict prevention. This collaborative work had had great results in the cases of Guinea or Burkina Faso, for example.

The area of West Africa has also been selected because interesting lessons can be obtained from the activities related to conflict prevention of its regional organization. Undoubtedly, the model developed by ECOWAS is the most interesting example in the

\footnotetext{
${ }^{5}$ Before known as the United Nations Office for West Africa (UNOWA).
} 
continent (Wulf \& Debiel, 2009).

At the end of 1990, the organization adopted the Protocol Relating to the Mechanism for Conflict Prevention, Management, Resolution, Peacekeeping and Security (The Mechanism), agreed on the Lome Summit on 10 December 1999, which is "the most important legal and normative instrument for ECOWAS in all matters relating to peace and security" (ECOWAS, 2018, p.16).

This legal instrument demonstrates that the prevention of conflicts acquires a great importance for the organization, since among the objectives of the Mechanism are the prevention of: internal and inter-State conflicts; serious and massive violations of human rights; or an overthrow or attempted overthrow of a democratically elected government.

A next step was the approval of the Protocol on Democracy and Good Governance adopted on 21 December 2001 and signed in Dakar, with the goal of incorporating provisions regarding topics such as prevention of internal crises (United Nations, n.d.).

The most recent agreement on preventive policies has been the ECOWAS Conflict Prevention Framework (ECPF), adopted by the Mediation and Security Council (the central organ of the Mechanism) on January 16 2008, in Ouagadougou. The ECPF sought to be the definitive impulse for the prevention of conflicts, acting as an strategic framework for conflict prevention and human security and looking for a more pro-active and operational conflict prevention posture from Member States (ECOWAS, 2008, p.12).

Finally, as a result of the agreements reached after the launch of the ECPF, in 2015 the ECOWAS Mediation Facilitation Division (MFD) was established under the Directorate of Political Affairs, with the aim of promoting preventive diplomacy in the region (ECOWAS, 2018).

This legal framework places ECOWAS as one of the most advanced regional organizations of Africa in conflict prevention. However, more than a decade after the ECPF was adopted, there are important constraints that limit its potential on the ground. The ECPF is an structure that is still in the course of being implemented and needs a long process of operationalization. One of the main challenges is the lack of funding, which depends on Member States ("Peace building experts, others, urge ECOWAS to animate the implementation of its Conflict Prevention Framework", 2019). The limited human and financial resources affect the development of the framework and makes the regional organization has to select in what contexts or in what situations intervene. Thus, in a region where there are significant challenges to peace and security, the lack of resources makes some risk factors do not get enough attention and that the actions focus on the most immediate threats (Yabi, 2010, p.55).

Together with resources constraints, there are other obstacles that conditionate the implementation of conflict prevention in the region, which will be analyse in the next section.

\section{Prevention on the ground}

Under this normative framework that has evolved and adapted to the changes and needs of the region's security scenario, ECOWAS has developed an important activity in preventive diplomacy and mediation in different contexts. With the objective of illustrating the conflict prevention policies of ECOWAS, somes cases of study have been 
selected (Table 1), analysing factors like the different contexts in which preventive measures were developed, the actors who participated together with ECOWAS or the type of actions that those actors carried out.

Table 1. Case studies of ECOWAS conflict prevention measures

\begin{tabular}{|c|c|c|}
\hline Cases $^{6}$ & Type of conflict & Preventive measures \\
\hline Liberia (1989) & Escalation to civil war & $\begin{array}{c}\text { Diplomatic and mediation } \\
\text { efforts } \\
\text { Military intervention }\end{array}$ \\
\hline Côte d'Ivoire (2010) & Electoral violence & $\begin{array}{c}\text { Institutional incentives } \\
\text { Imposition of sanctions } \\
\text { Suspension of Guinea as a } \\
\text { member of ECOWAS }\end{array}$ \\
\hline Burkina Faso (2014) & Public demostrations & $\begin{array}{c}\text { Suspension of Côte d'Ivoire } \\
\text { as a member of ECOWAS } \\
\text { Imposition of sanctions } \\
\text { Sent of diplomatic } \\
\text { delegations } \\
\text { Threat of use of force }\end{array}$ \\
\hline The Gambia (2016) & Electoral violence & $\begin{array}{c}\text { Imposition of sanctions } \\
\text { Arms embargo } \\
\text { Early warning mission }\end{array}$ \\
\hline Togo (2017) & Public demonstrations & $\begin{array}{c}\text { Diplond mediation } \\
\text { efforts } \\
\text { Preventive deployment }\end{array}$ \\
\hline Monitoring activities \\
\hline
\end{tabular}

Source: author's elaboration

Due to the theoretical framework that has been established to analyze the evolution of conflict prevention doctrine in this article begins with the end of the Cold War, the first selected case of analysis is Liberia (1989). It is, moreover, the first civil war in the region that test the ECOWAS crisis management capacities.

The first Liberian civil war began when rebels led by Charles Taylor crossed the border from Côte d'Ivoire to fight against Samuel Doe's government. At that time, the legal instruments ${ }^{7}$ used by ECOWAS did not contemplate the prevention of internal conflicts, but rather between States. Some of the first steps made by the regional organization were focus on diplomatic attempts, creating the Standing Committee on Mediation in May 1990 (Suifon, n.d., p.3). However, those efforts failed and ECOWAS decided to act because the crisis was considered a regional problem (Human Rights Watch, 1993).

Despite the fact that ECOWAS intervention occured once the war has broken out -that is why the intervention was considered "largely reactive" (ECOWAS, 2018, p.35)- it was the only actor who adopted an active attitude in the conflict and, as some authors have pointed out, the military intervention was successful "at lease for a short period, preventing the situation from degenerating into genocidal proportions" like that of

${ }^{6}$ The dates that are included in parentheses reflect the year in which the violence begins.

7 At that time only existed the Protocol on Non-Aggression of 1978 and the Protocol on Mutual Assistance on Defense of 1981. 
Rwanda (Draman \& Carment, 2003, p.17).

Another example is the crisis opened in Guinea with the Lansana Conté's succession. After his death, in December 2008, Captain Moussa Dadis Camara and fellow military officers led a coup d'État. The situation started worsening when he decided to present himself to next presidential election, an announcement that provoked strong protests in September 2009 that culminated with the massacre occured at the National Stadium of Conakry, committed by soldiers under the command of the military junta (Human Rights Watch, 2009). The government received "pressure and incentives [by ECOWAS] to allow elections to take place and to enable an international investigation into the massacre (Day \& Pichler Fong, 2017, p.8).

Both ECOWAS and the AU used coercitive tools, such as the imposition of sanctions and the suspension of Guinea as member of the regional organization. Moreover, there was an important external pressure and preventive measures like threats of prosecution by the International Criminal Court were used (Day \& Pichler Fong, 2017, p.7). This had an effective effect on some fellows of Camara, who suffered an assassination attempt that forced his leave, facilitating the transition to civilian rule.

The UN also took a preventive attitude in this crisis through its regional office, UNOWAS (then the United Nations Office for West Africa -UNOWA), and the Regional Coordinator, who developed "intensive preventive diplomacy efforts" (Von Einsiedel et al., 2018, p.15), acting as mediator with different stakeholders. Moreover, UNOWA provided logistical and technical support to ECOWAS, that had the real leadership as mediator, and more particularly, one of its Member States, Burkina Faso, whose president convinced the transitional goverment to organize elections. Thus, "the engagement of ECOWAS [...] was largely considered a successful effort to avert further violence or escalation to civil war" (Hara, 2011).

Another interesting experience for the regional organization was the civil war that arises in Côte d'Ivoire after the 2010's presidential elections. While the Electoral Commission, as well as the international community, declared Alassane Ouattara the winner, Laurent Gbagbo refused to accept the result as the Constitutional Council announced that he was the real victor because he had obtained a larger percentage than his rival (Cook, 2011). Given this scenario, ECOWAS asked the parties to respect the results and to celebrate an extraordinary meeting, although they clearly showed their support for Ouattara.

Some of the first steps taken by the regional organization were the suspension of Côte d'Ivoire as a member at the beginning of December, in addition to the UA, forcing Gbagbo to accept the results (Cook, 2011) and the imposition of sanctions, following article 45 of the Protocol on Democracy and Good Governance. Both organizations sent diplomatic delegations, such as the one led by the former president of South Africa, Thabo Mbeki, who traveled to the country to make a generic call for peace and democracy, but without issuing an important statement (Al Jazeera, 2010).

In the absence of action of the UN -that received a lot of criticism from different organizations for its indifference- ECOWAS decided to take action. At the end of December 2010, ECOWAS gave an ultimatum to Gbagbo, using the threat of the use of force, that was ignored it, for which the organization found itself without options, and had to contemplate other measures, including the use of force (Cook, 2011). On December 31, a Nigerian defense spokesman announced that ECOWAS military chiefs from several member countries had "prepared plans to 'forcefully take over power' from 

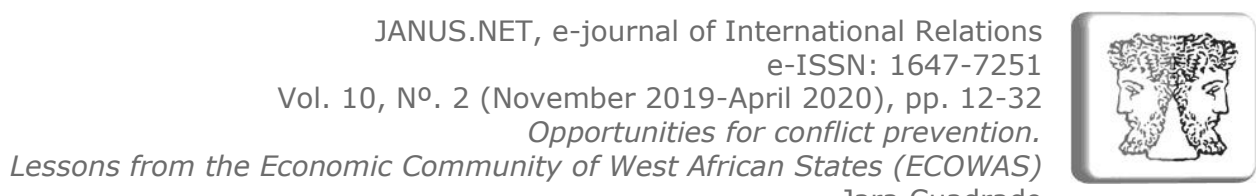
Jara Cuadrado

Gbagbo using a grouping of troops called the ECOWAS standby force [...] if diplomatic efforts to pressure him to cede the presidency fail" (Cook, 2011, p.39). However, military intervention was finally conducted "by French, UN and pro-Ouattara 'Republican' forces" (Yabi, 2012, p.3).

Despite the slowness with which preventive measures were carried out and despite the external dependence to act, as some studies point out, it is interesting to highlight that the second civil war in the Côte d'Ivoire would be one of the clearest examples in which ECOWAS made use of preventive diplomacy (Kwabena, 2015).

The following example is found in Burkina Faso, which in 2014 experienced a stage of public opposition due to President's intentions to extend his term limit. This provoked mass demonstrations that led to the resignation of then-President Blaise Compaoré (Taoko, Cowell \& Callimachi, 2014). Subsequently there was an attempted coup d'État against the transition authorities.

There were important preventive measures, such as the imposition of sanctions asked by ECOWAS to the AU ("UNOWA head Mohammed Ibn Chambas to brief on Burkina Faso", 2015), who also "decided to suspend the participation of Burkina Faso from all AU activities" (Desmidt, 2019, p.12). As some studies have pointed out (Day \& Pichler Fong, 2017, p.7), these pressures were one of the key factors for "averting further chaos and a high risk of violence". ECOWAS decided to impose an arms embargo in September ("ECOWAS arms embargo on Guinea", n.d.).

Moreover, civil society organizations played an important preventive role in the crisis, since they organized several workshops throughout the previous year of the elections on monitoring and preventing violence, in which politicians and media were involved.

Despite these preventive measures, Compaoré refused to leave the power, and ECOWAS decided to intervene together with UNOWA and deployed a joint early warning mission with the aim of promoting a national dialogue between national political actors and civil society. However, the president kept strong while tensions continued rising. This provoked a new intervention of both actors to which the AU decided to join.

Finally, joint efforts resulted in "a new Constitution and a one-year civilian-led transition that would culminate with general elections in November 2015" (United Nations, 2018, p.6). The support of ECOWAS and its mediation efforts during the transition period were key for the successful of the national dialogue. Equally important was the collaborations with UNOWA, that gave its support to the regional organization, and with the AU, since in spite of initial disagreements, in the end there was a collaborative work.

The same circumstances occured in The Gambia at the end of 2016, when President Yahya Jammeh refused to accept his defeat in the December elections. This provoked a climate of tension in the country that led ECOWAS to get involved, initiating diplomatic and mediation work with President Jammeh to accept the results of the elections (ECOWAS, 2017). There were several occasions in which the leaders of the region met with both Jammeh and the elected president, Adama Barrow (Alfa Shaban, 2017).

Before considering a preventive deployment, ECOWAS' Members developed mediation efforts through high-level delegation visits in December 2016 (Desmidt, 2019, p.7). Finally, ECOWAS decided to intervene on January 192017 according with the Article 25 of the ECOWAS Mechanism and with the support of the UN and the AU (Day \& Pichler Fong, 2017). The deployment of the ECOMIG would be applauded by the international 


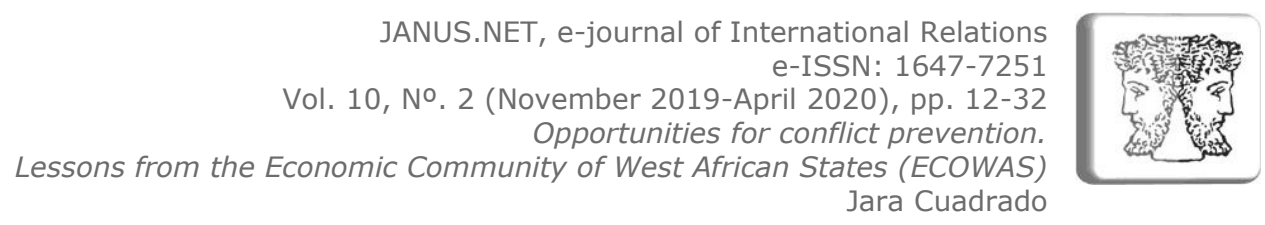

community (Alfa Shaban, 2017). The good coordination between the UN and ECOWAS was reflected by the role played by UNOWAS, that held "meetings with representatives of the government, opposition parties, civil society and women and youth organizations" ("Peaceful and credible elections: A case of UNOWAS' holistic coordination", 2017, p.7).

The Gambia has been an example of the success of ECOWAS preventive policies and could be highlighted as a paradigm for future crises in the region; this preventive deployment has served to prevent a post-electoral context of tension leading to an escalation of violence.

Anti-government protests were also echoed in another country of the region, Togo, where at the end of August 2017 a wave of demonstrations demanding constitutional reforms and the resignation of the President Faure Gnassingbé Eyadéma ${ }^{8}$ broken out, which were harshly repressed (RFI Afrique, 2017). The regional organization called then for peace "upon all political stakeholders and the people of Togo to exercise restraint and refrain from violence, and dialogue in order to preserve peace" (RFI Afrique, 2017).

ECOWAS' countries intervened, beginning a dialogue process between the ruling party and the opposition that was initiated with the Presidents of Ghana and Guinea as the lead mediators (United Nations, 2017b). Within ECOWAS, there was satisfaction for the preventive efforts made by these two leaders ("ECOWAS hails Akufo-Addo, Alpha Condé over Togo intervention", 2018). The regional organization set the celebration of parliamentary elections on December 2018. For that purpose, the "organization urged the Togolese government to proceed with the complete revision of the electoral roll prior to these legislative" (Gbenyedji, 2018). Parliamentary elections were finally celebrated on December 20, with a victory of the ruling party, who ignored the recommendations from the regional organization.

\section{Conclusiones}

These contexts of political and social instability are some examples in which the preventive tools of ECOWAS and its coordination with other actors have been tested as well as they have served to improve the management of its security challenges. Through the study of these cases, it has been possible to see some of the tools the organization can use to prevent conflicts, such as preventive diplomacy -through mediation and dialogue between the parties-, the imposition of sanctions, the suspension from membership of a Member State, or the threat of the use of force as a deterrent. The analysis of these experiences showed that ECOWAS has had an important activity on conflict prevention.

But these experiences have also revealed the main challenges that the organization face in terms of prevention. Crises such as the one currently taking place in Togo or past cases like Côte d'Ivoire have revealed the vulnerabilities of its policies.

Some of the main obstacles detected in the ECOWAS conflict prevention policies can be summarised as follows. Firstly, there is a group of factors related to aspects like the fight for political power, the personal relationships, or typical dynamics of power structures. Within this group is the divergence of stakeholder's interests. As it has been observed, the agents involved in those scenarios maintained different attitudes to the crises. This

\footnotetext{
${ }^{8}$ His family is the longest in a West African government.
} 


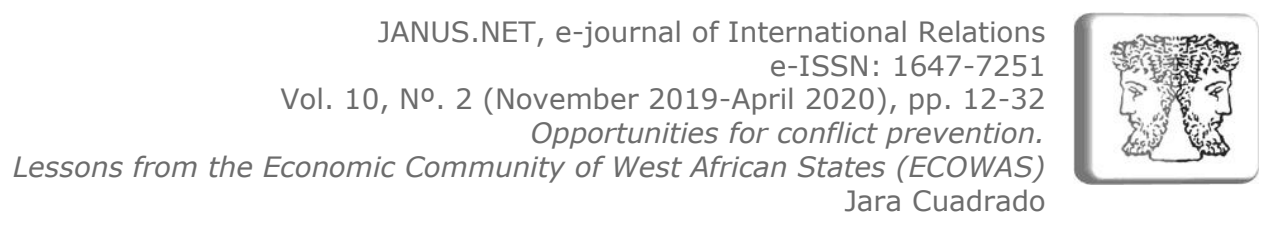

lack of agreement or understanding among crucial actors explains the slowness with which the measures were applied once the early warnings were identified.

The clash of interest between ECOWAS Member States was present during the First Liberian War. Nigeria wanted to play a leadership role while the government of Burkina Faso had personal interest in the crisis due to his ties with Liberian dissidents (Murison, 2004, 603), which affected the decision-making.

There have also been clashes of interests between the regional organization and the continental organization, the $A U$, which had repercussions on the ground, turning the decision-making about the management of crises difficult. During the previous context of the Liberian civil war, for example, the countries of the Organization of African Unity $(O A U)$, predecessor of the $A U$, showed a different position than the one that ECOWAS had. The OAU was opposed to a military intervention in Liberia, especially those countries that supported Charles Taylor, the rebel leader (Wippman, 1993, p.165). This lack of a common action between the two organizations was also present in the Côte d'Ivoire's electoral crisis of 2010, since within the AU there were disparity of positions on the support to the two political leaders, Ouattara and Gbagbo, ECOWAS kept a posture of unity.

Moreover, partiality was present in some cases. Some of the Member States of ECOWAS had significant influence in the political context of Côte d'Ivoire, such as the president of Burkina Faso, Blaise Compaoré, who could have put more pressure on the parties. The role played by his government was seen as not neutral by other ECOWAS Member States, since he "has been strongly identified as an ally of Ouattara and accused of being a key mover behind the initial insurgency in [Côte d'Ivoire] in September 2002" (The Guardian, 2011). This lack of impartiality existed also in Togo. One of the main obstacles for the dialogue experts saw (RFI Afrique, 2017) was that the presdient of Togo had been chairman of ECOWAS for one-year, until June 2018. This is an important factor to consider, since the regional organization was not revealing a neutral position to this crisis and there was a certain lack of political will to act. As some organizations have described, there was abuse of power and dictatorial measures during the electoral contexts (Bailey, 2019), but both ECOWAS and the AU have call the elections as "free and transparent" ("Togo President's Party Wins Majority in Parliament", 2018).

Added to this, it is the lack of political will to deploy measures. A clear example is Guinea, since despite the successul final result, with a pacific transitional government, it is necessary to highlight that the crisis and specially the deaths of civilians could have been prevented if stakeholders, mainly ECOWAS, had reacted more immediately to the coup d'État. Thus, between the coup d'État and the massacre of September 2009 some other measures could have been used, such as imposition of sanctions and an arms embargo, which were launched immediately after the high death of civilians.

In addition, contradictions often occur in the approaches and functions to be performed when collaborating with the AU. Strong disagreements between both organizations were presented during the crisis in Burkina Faso. However, there are some examples in which the cooperation between them had positive impacts on the ground, like in Guinea o The Gambia (Kreß \& Nußberger, 2017).

Secondly, it is neccessary to have in mind a group of factors related to more operational or logistic aspects that are present in organizations like ECOWAS, like the complex bureaucracy, which makes decision-making difficult, and prolongs the time that elapses 

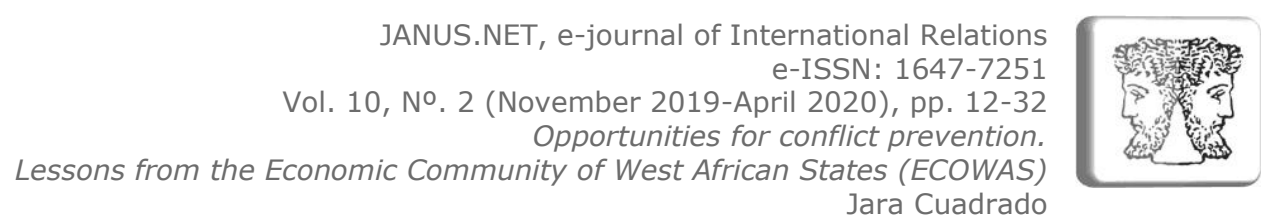

from the decision to implement a preventive measure up to the application of that measure. In addition, this sometimes makes it difficult to design a strategic approach (Yabi, 2010, p.13), as it occured, for example, in the case of Côte d'Ivoire. At the end of 2010, when the electoral crisis was driving to an escalation of violence, ECOWAS threated with the use of force, but in January the mission had not been yet launched, so the suspicion was confirmed that an intervention by force would be difficult to deploy since it lacked a plan and it would require additional resources (Kwabena, 2015, p.32).

This last aspect is a very important constraint that has been present in all the cases analysed in this article. The lack of human and financial resources in ECOWAS makes it has dependency on the external ators to be able to intervene preventively.

Finally, it is important to highlight the need to incorporate the work of civil society organizations (CSO), as it has been underlined in recent political meetings ("Peace building experts, others, urge ECOWAS to animate the implementation of its Conflict Prevention Framework", 2019). Collaboration between ECOWAS and CSO has proved to be very useful in contextst such as Burkina Faso (Somé, 2014).

In conclusion, the organization still has a long way to go to become an effective actor, given the complexity of the challenges it faces, many of which do not only have an internal character, but also feed on external factors. Currently, it seems that regional political actors in West Africa have a commitment to implement the organization's framework of action in conflict prevention (African Media Agency, 2019; "Peace building experts, others, urge ECOWAS to animate the implementation of its Conflict Prevention Framework", 2019). Thanks to the management developed in cases such as The Gambia, ECOWAS has received the applause from the international community. This regional actor plays undoubtedly a key role in implementing conflict prevention and among its priorities it is to continue developing and improving preventive policies ("ECOWAS launches Plans of Action for its Conflict Prevention Framework", 2019). The history of this regional organization offers interesting lessons on the importance that the regionalization of security has for the African continent, where conflict prevention could become the main challenge.

\section{References}

Adebajo, A. (2002). Building Peace in West Africa: Liberia, Sierra Leone, and GuineaBissau. Boulder: Lynne Rienner Publishers.

African Media Agency (2019, May 23). ECOWAS is marking a decade of the operationalisation of the ECOWAS Conflict Prevention Framework. Retrieved from: http://amediaagency.com/ecowas-is-marking-a-decade-of-the-operationalisation-ofthe-ecowas-conflict-prevention-framework/

Alfa Shaban, A. R. (2017, September 15). ECOWAS' mediation headache: The Gambia unlike Togo, Africanews.com. Retrieved from: http://www.africanews.com/2017/09/15/ecowas-mediation-headache-the-gambiaunlike-togo/

Al Jazeera (2010, September 7). Mbeki fails to end Ivorian crisis. Retrieved from: https://www.aljazeera.com/news/africa/2010/12/2010126203135142778.html 

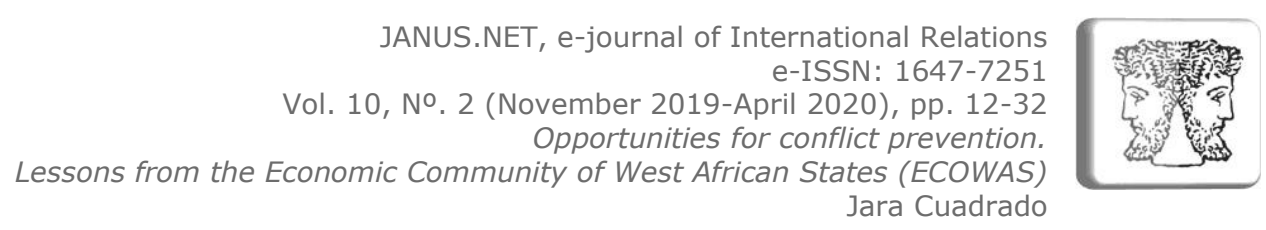

Bailey, N. (2019, January 28). Elections in Togo: What Happens When the World Isn't Watching. Freedom House. Retrieved from: https://freedomhouse.org/blog/electionstogo-what-happens-when-world-isn-t-watching

Berman, E. G. (2002). African Regional Organisation' Peace Operations. Developments and Challenges, African Security Review, 11 (4), 33-44.

Buzan, B., Wæver, O., \& Wilde, J. (1998). Security: A new framework for analysis. Boulder, Colo: Lynne Rienner Pub.

Buzan, B., Wæver, O., \& Wilde, J. (2003). Regions and Powers: The Structure of International Society. Cambridge: Cambridge University Press.

Carnegie Corporation of New York (1997). Preventing Deadly Conflict. Final Report. Nueva York: Carnegie Commission on Preventing Deadly Conflicts.

Cook, N. (2011). Côte d'Ivoire Post-Gbagbo: Crisis Recovery. Washington: Congressional Research Service.

Cuadrado, J. (2018). Las Naciones Unidas y los sistemas de alerta temprana: lecciones desde el escenario de África Occidental. Revista Española de Ciencia Política, 46, 175198. Retrieved from: https://recyt.fecyt.es/index.php/recp/article/view/59079

Darkwa (2017). The African Standby Force: The African Union's tool for the maintenance of peace and security. Contemporary Security Policy, 38(3), 471-482. Retrieved from: https://www.tandfonline.com/doi/full/10.1080/13523260.2017.1342478?scroll=top\&ne edAccess $=$ true

Day, A. \& Pichler Fong, A. (2017). Diplomacy and Good Offices in the Prevention of Conflict A Thematic Paper for the United Nations - World Bank Study on Conflict Prevention. United Nations University Centre for Policy Research Conflict Prevention Series, $3 . \quad$ Retrieved from: https://reliefweb.int/sites/reliefweb.int/files/resources/DiplomacyGoodOfficesinPreventi onofConflict-Aug-2017.pdf

De Carvalho, G. (2017). Conflict prevention: what's in it for the AU?, Institute for Security Studies, Policy Brief 103. Retrieved from: https://css.ethz.ch/content/dam/ethz/specialinterest/gess/cis/center-for-securities-studies/resources/docs/ISS_Africapolicybrief103.pdf

Desmidt, S. (2019). Conflict management and prevention under the African Peace and Security Architecture (APSA) of the African Union. Africa Journal of Management. African Journal of Management, 5(1), 79-97. Retrieved from: https://www.tandfonline.com/doi/abs/10.1080/23322373.2018.1563465?af=R\&journal Code $=$ rajm 20

Desmidt, S. \& Hauck, V. (2017). Conflict management under the African Peace and Security Architecture (APSA). Analysis of conflict prevention and conflict resolution interventions by the African Union and Regional Economic Communities in violent conflicts in Africa for the years 2013-2015. European Centre for Development Policy Management, Discussion Paper 211. Retrieved from: https://ecdpm.org/publications/conflict-management-under-the-apsa/

Dorn, A. \& Matloff, J. (2000). Preventing the Bloodbath: Could the UN have Predicted and Prevented the Rwandan Genocide? Journal of Conflict Studies, 20 (1). 
JANUS.NET, e-journal of International Relations e-ISSN: $1647-7251$

Vol. 10, No. 2 (November 2019-April 2020), pp. 12-32 Opportunities for conflict prevention.

Draman, R. \& Carment, D. (2003). Managing Chaos in the West African Sub-Region: Assessing the Role of ECOMOG in Liberia. Journal of Military and Strategic Studies, 6, (2).

"ECOWAS arms embargo on Guinea" (n.d.). Stockholm International Peace Research Institute (SIPRI). Retrieved from: https://www.sipri.org/databases/embargoes/eu_arms_embargoes/Guinea/ECOWAS_e mbargo_on_Guinea

"ECOWAS hails Akufo-Addo, Alpha Condé over Togo intervention" (2018, December 24). GhanaWeb. Retrieved from: https://www.ghanaweb.com/GhanaHomePage/NewsArchive/ECOWAS-hails-AkufoAddo-Alpha-Cond-over-Togo-intervention-711004\#).

"ECOWAS launches Plans of Action for its Conflict Prevention Framework" (2019, January 25). ECOWAS Info. Retrieved from: https://www.ecowas.int/ecowas-launches-plans-ofaction-for-its-conflict-prevention-framework/

"Peace building experts, others, urge ECOWAS to animate the implementation of its Conflict Prevention Framework" (2019, May 26). ECOWAS Info. Retrieved from: https://www.ecowas.int/peace-building-experts-others-urge-ecowas-to-animate-theimplementation-of-its-conflict-prevention-framework/

ECOWAS (2008). The ECOWAS Conflict Prevention Framework. Retrieved from: https://www.lawschool.cornell.edu/womenandjustice/upload/ECOWAS-Conflict-

Prevention-Framework.pdf

ECOWAS (2017). ECOWAS Authority Chair, President Sirleaf Comments on ECOWAS Mediation Intervention in the Gambia. ECOWAS Info. Retrieved from: http://www.ecowas.int/ecowas-authority-chair-president-sirleaf-comments-on- ecowasmediation-intervention-in-the-gambia/

ECOWAS (2018). ECOWAS Mediation Guideline. Abuja: ECOWAS Commission.

El Abdellaoui, J. (2009). Th e Panel of the Wise A comprehensive introduction to a critical pillar of the African Peace and Security Architecture, Institute for Security Studies, ISS Paper 199. Retrieved from: https://www.files.ethz.ch/isn/105916/PAPER193.pdf

Evans, G. (2016). "Preventing and Resolving Deadly Conflict: What Have We Learned?", in Khouri, R., Makdisi, K. \& Wählisch, M. (eds.), Interventions in Conflict. International Peacekeeping in the Middle East. New York: Palgrave McMillan.

Francis, D. J. (2006). Linking peace, security and developmental regionalism: Regional economic and security integration in Africa. Journal of Peacebuilding \& Development, 2(3), 7-20.

García Izquierdo, B. (2002). Una nueva oportunidad para la prevención de conflictos: análisis comparativo de las políticas de Estados Unidos y de la Unión Europea sobre la prevención de conflictos violentos. Deusto: Universidad de Deusto.

Gbenyedji, C. (2018, August 1). Political crisis in Togo : ECOWAS has given its verdict! Grand Mag Afrique. Retrieved from: http://grandmagafrique.com/en/2018/08/01/crisepolitique-au-togo-la-cedeao-a-rendu-son-verdict/ 

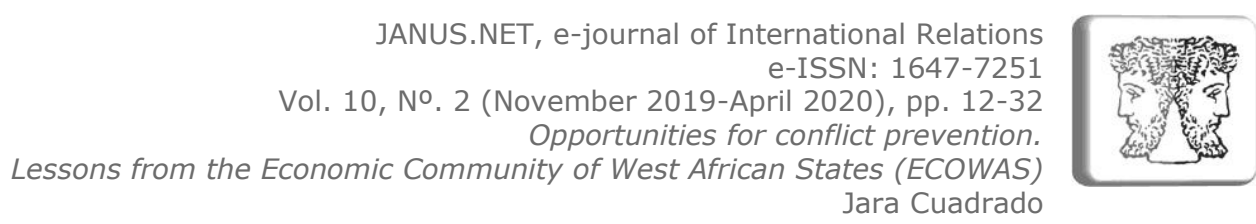
Jara Cuadrado

Gowan, R. (2017). Bordering on Crisis: Europe, Africa, and a New Approach to Crisis Management. European Council on Foreign Relations, Policy Brief April 2017. Retrieved from: https://www.ecfr.eu/page/-/Bordering on crisis02.pdf

Hara, F. (2011, December 31). Preventive Diplomacy in Africa: Adapting to New Realities. International Crisis Group. Retrieved from: https://www.crisisgroup.org/africa/preventive-diplomacy-africa-adapting-new-realities

Hartmann, C. (2017). ECOWAS and the Restoration of Democracy in the Gambia, Africa Spectrum, vol. 52(1): 85-99.

Human Rights Watch (1993). Waging War to Keep the Peace: The ECOMOG Intervention and Human Rights, 5 (6). Retrieved from: https://www.hrw.org/reports/1993/liberia/

Human Rights Watch (2009, December 17). Guinea: Stadium Massacre, Rape Likely Crimes Against Humanity. Retrieved from: https://www.hrw.org/news/2009/12/17/guinea-stadium-massacre-rape-likely-crimesagainst-humanity

Igaripé Institute (2018). The Handbook of Conflict Prevention. Retrieved from: https://igarape.org.br/wp-content/uploads/2018/12/The-Handbook-of-ConflictPrevention.pdf

Institute for Security Studies (2015, November 4). Understanding the African Standby Force, rapid deployment and Amani Africa II, ISS Media Toolkit. Retrieved from: https://issafrica.s3.amazonaws.com/site/uploads/4-11-2016-ASF-Amani-MediaToolkit1.pdf

Jetschke, A. \& Schlipphak, B. (2019). MILINDA: A new dataset on United Nations-led and non-united Nations-led peace operations, Conflict Management and Peace Science, pp. $1-25$.

Kelly, R. (2007). Security Theory in the "New Regionalism". International Studies Review, 9, (2), 197-229.

Kreß, C. \& Nußberger, B. (2017). Pro-democratic intervention in current international law: the case of The Gambia in January 2017. Journal on the Use of Force and International Law, 4(2), 239-252. Retrieved from: https://www.tandfonline.com/doi/pdf/10.1080/20531702.2017.1338466?needAccess=t rue

Kwabena, A. A. (2015). An Examination of the Mechanism of Preventive Diplomacy in Conflict Resolution in Africa: The Case of Cote d'Ivoire. Doctoral dissertation, University of Ghana.

Leone, F. (2017). Conflict Prevention is 'The Priority' says UN Secretary-General.

SDG Knowledge Hub. Retrieved from: http://sdg.iisd.org/news/conflict-preventionis-the-priority-says-un-secretary-general/.

Lotze, W. (2015). The Future of African Peace Operations: Time to Adjust the Operational Design. Center for International Peace Operations, Policy Briefing May 2015. Retrieved from:

https://www.zifberlin.org/fileadmin/uploads/analyse/dokumente/veroeffentlichungen/ZIF_Policy_Briefi ng_Walter_Lotze_Future_African_Peace_Operations_May_2015.pdf 
JANUS.NET, e-journal of International Relations e-ISSN: $1647-7251$

Vol. 10, No. 2 (November 2019-April 2020), pp. 12-32 Opportunities for conflict prevention.

Lund, M. (1993). Preventing violent conflict a strategy for preventive diplomacy. Washington: USIP.

Lund, M. (2009). Conflict Prevention: Theory in Pursuit of Policy and Practice. In Bercovitch, J., Kremenyuk, V. \& Zartman, I. W. (eds.), The Sage Handbook of Conflict Resolution. New York: SAGE Publications Ltd.

Menkhaus, K. (2004). Conflict prevention and human security: issues and challenges, Conflict, Security \& Development, vol. 4(3): 419-463.

Moller, B. (2009). The African Union as Security Actor: African Solutions to African Problems. Crisis State Research Centre, Working Paper 2.

Murison, K. (2004). Africa South of the Sahara 2004. London: Europa Publications.

Nathan, L. (2017). How to Manage Interorganizational Disputesover Mediation in Africa.

Global Governance 23, 151-162. Retrieved from: https://www.researchgate.net/publication/316797148_How_to_Manage_Interorganizati onal_Disputes_over_Mediation_in_Africa

"Peaceful and credible elections: A case of UNOWAS' holistic coordination" (2017). UNOWAS e-magazine issue 5. Retrieved from: https://unowas.unmissions.org/unowase-magazine-issue-5-free-credible-elections-major-tool-consolidating-democracy-anddevelopment

Persson, J. (2012). Regions as Security Providers The Evolution of the West African Regional Security Complex. PhD dissertation, Lund University. Retrieved from: https://pdfs.semanticscholar.org/cae5/663f43e48a7899b2f04c9e2ec56a60bb6aca.pdf

Ramsbotham, O., Miall T. \& Woodhouse, H. (2011). Resolución de conflictos. La prevención, gestión y transformación de conflictos letales. Barcelona: Bellaterra.

Rappa, R. (2016, September 7). The Challenges of Full Deployment on UN Peace Operations. Global Peace Operations Review. Retrieved from: https://peaceoperationsreview.org/thematic-essays/the-challenges-of-full-deploymenton-un-peace-operations/

RFI Afrique (2017, August 2018). Togo: climat de peur et de tension après les manifestations réprimées. Retrieved from: http://www.rfi.fr/afrique/20170820-togopeur-tension-Iome-anie-kara-sokode-manifestations-pnp-reprimees-deux-morts

Roberts, M. (2017, March 3). Prevention Could Be Cure for a UN in Flux. International Peace Institute Global Observatory. Retrieved from: https://theglobalobservatory.org/2017/03/prevention-united-nations-guterres-syria/

Somé, B. (2014, November 24). Back to the future in Burkina Faso, Peace Insight. Retrieved from: https://www.peaceinsight.org/es/blog/2014/11/back-future-burkinafaso/?en $=1$

Sousa, R. (2017). United Nations Security Council primacy over military interventions in Africa and the African Peace and Security Architecture (APSA). In Moita, L. \& Pinto, L. V. (Coord.), Espaços económicos e espaços de segurança (pp. 519-572). Lisboa: UAL \& OBSERVARE 
JANUS.NET, e-journal of International Relations e-ISSN: 1647-7251

Vol. 10, No. 2 (November 2019-April 2020), pp. 12-32 Opportunities for conflict prevention.

Stanton, G. (2005). The 12 Ways to Deny a Genocide, Genocide Emergency: Darfur, Sudan. Genocide Watch. Retrieved from: http://www.genocidewatch.org/aboutgenocide/12waystodenygenocide.html

Sugars, S. (2017, September 18). Conflict prevention: will the United Nations return to its roots? Open Democracy. Retrieved from: https://www.opendemocracy.net/5050/stephanie-sugars/united-nations-reformconflict-prevention

Suifon, T. Z. (n.d.). ECOWAS' Sub-regional Peacekeeping: Learning through Experience. WANEP. Retrieved from: http://www.wanep.org/wanep/attachments/article/101/tp ecowas subregional peacek eeping.pdf

Taoko, H., Cowell, A. \& Callimachi, R. (2014, October 30). Violent Protests Topple Government in Burkina Faso. The New York Times. Retrieved from: https://www.nytimes.com/2014/10/31/world/africa/burkina-faso-protests-blaisecompaore.html

Tavares, R. (2009). Regional Security: The Capacity of International Organizations. London: Routledge.

The Guardian (2011, January 11). West African leaders search for a regional solution in Ivory Coast. Retrieved from: https://www.theguardian.com/globaldevelopment/2011/jan/11/ivory-coast-gbagbo-ecowas-diplomacy-military

"Togo President's Party Wins Majority in Parliament" (2018, December 24). Voa News. Retrieved from: https://www.voanews.com/a/togo-president-s-party-wins-majority-inparliament/4713975.html

United Nations (n.d.). Protocol on Democracy and Good Governance (A/SP1/12/01). Retrieved from: https://www.ohchr.org/EN/Issues/RuleOfLaw/CompilationDemocracy/Pages/ECOWASPr otocol.aspx

United Nations (1945). Charter of the United Nations. Retrieved from: http://www.un.org/en/charter-united-nations/

United Nations (2002). Statement by the President of the Security Council, S/PRST/2002/2, 31 January 2002.

United Nations (2014a). 15 de enero). World must heed early warning signs to prevent genocide, UN is told, UN News Centre. Retrieved from: http://www.un.org/apps/news/story.asp?NewsID=46936\#.WRxoBoVOKU

United Nations (2014b). Security Council Resolution 2167, Security Council S/RES/2167 (2014), July 28, 2014.

United Nations (2015). Report of the Secretary-General on the United Nations and conflict prevention: a collective recommitment, September 2015. Retrieved from: https://undocs.org/S/2015/730

United Nations (2016). Letter from António Gutteres to President of the United Nations General Assembly, 4 April 2016. Retrieved from: https://www.un.org/pga/70/wpcontent/uploads/sites/10/2016/01/4-April_Secretary-General-Election-Vision-

Statement_Portugal-4-April-20161.pdf 
JANUS.NET, e-journal of International Relations e-ISSN: 1647-7251

Vol. 10, No. 2 (November 2019-April 2020), pp. 12-32 Opportunities for conflict prevention. Jara Cuadrado

United Nations (2017a). Podcast special: We need "a surge in diplomacy for peace" Guterres, UN News, 8 September 2017. Retrieved from: https://news.un.org/en/audio/2017/09/632842

United Nations (2017b). Joint UNDP-DPA Programme on Building National Capacities for Conflict Prevention. Annual Report 2017. Retrieved from: http://www.undp.org/content/dam/undp/library/Democratic\%20Governance/Conflict\% 20Prevention/UNDP-DPA_JointProgramme_AnnualReport_2017.pdf

United Nations (2018). United Nations Conflict Prevention and Preventive Diplomacy In Action, Department of Political Affairs. Retrieved from: https://www.un.org/undpa/sites/www.un.org.undpa/files/Booklet_200618_fin_scrn.pdf

United Nations Office to the African Union (n.d.). Conflict prevention, including early warning and mediation. Retrieved from: https://unoau.unmissions.org/conflictprevention-including-early-warning-and-mediation

UNOWA head Mohammed Ibn Chambas to brief on Burkina Faso (2015, October 5). What's in Blue. Retrieved from: https://www.whatsinblue.org/2015/10/unowa-headmohammed-ibn-chambas-to-brief-on-burkina-faso.php

Von Einsiedel, S., Kaye, J., Salih, C., MacClinchy,W. \& Galtieri, F. (2018). What Works in UN Resident Coordinator-led Conflict Prevention: Lessons from the Field. United Nations University Centre for Policy Research. Retrieved from: http://collections.unu.edu/eserv/UNU:6547/RC-Project-Book-Upd-29JUN18.pdf

Williams, P. (2017). Global and Regional Peacekeepers: Trends, Opportunities, Risks and a Way Ahead, Global Policy, vol. 8(1): 124-129.

Wippman, D. (1993). Enforcing the Peace: ECOWAS and the Liberian Civil War. In Damrosch, L. F. (ed.), Enforcing Restraint. New York: Council on Foreign Relations.

Wulf, H. \& Debiel, T. (2009). Conflict early warning and response mechanisms: tools for enhancing the effectiveness of regional organisations? A comparative study of the AU, ECOWAS, IGAD, ASEAN/ARF and PIF. Crisis States Research Centre working papers series 2, 49, Crisis States Research Centre, London School of Economics and Political Science. Retrieved from: http://eprints.Ise.ac.uk/28495/1/WP49.2.pdf

Yabi, G. (2010). The Role of ECOWAS in Managing Political Crisis and Conflict: The Cases of Guinea and Guinea-Bissau. Abuja: Friedrich-Ebert-Stiftung.

Yabi, G. (2012). Keeping the Peace in Electoral Conflicts: The Role of ECOWAS, UNOCI and the Inter national Community in Côte d'Ivoire, Center for International Peace Operations, Policy Briefing. Retrieved from: https://www.zifberlin.org/fileadmin/uploads/analyse/dokumente/veroeffentlichungen/ZIF_Policy_Briefi ng_Gilles_Yabi_Oct_2012.pdf 


\title{
THE INFLUENCE OF CLIMATE CHANGE ON THE ESCALATING COMMUNAL CONFLICT BETWEEN HERDSMEN AND FARMERS: THE CASE OF THE FULANI ETHNIC GROUP IN NIGERIA
}

\begin{abstract}
Gustavo Furini
gustavofurini@gmail.com

Ph.D. student in International Relations: Geopolitics and Geoeconomics at Universidade Autónoma de Lisboa - UAL (Portugal). Holder of a master degree in Natural Resource Management and Local Development in the Amazon from UFPA (Brazil) and of a bachelor degree in Geography from UFRGS (Brazil). Has been working in the area of climate change since 2005, with experience in the public and private sectors.
\end{abstract}

\section{Abstract}

Current scientific evidence shows that human activities are causing interference at different levels in the global climate and availability of natural resources, and many authors already relate water scarcity to the increased risk of violent conflict, particularly in rural societies on the African continent. Climate disruptions caused by climate change are reflected on a regional and local scale, and the greatest impacts are already being felt in the poorest areas of the planet. Nigeria, Africa's most populous country, has been facing environmental problems in its territory that can be associated with climate change, such as rising temperatures, reduced rainfall and advancing desertification. Considering that all these phenomena have been worsening since the early twentieth century in Nigeria and, due to the escalating of violent conflicts since the beginning of the current century, the objective of this paper is to analyse how climate change can interfere in the conflict between herdsmen and farmers, as well as the possible impact of seasonal variation in rainfall on the dynamics of these communal conflicts. The study focused on literature review and the case study took place in four Nigerian states (Plateau, Benue, Taraba and Nasarawa) for the period 2010-2017, focusing on the communal conflict involving the Fulani ethnic group. The approach adopted was the inductive method in which the behaviour of rainfall in the study area was compared with the number of deaths resulting from the conflict, in addition to using geo-processing software to understand the spatial and temporal distribution of casualties. The theoretical framework used was that proposed by Thomas Homer-Dixon (1994) and the information was collected from primary sources, with consultation of qualitative and quantitative data, and from secondary sources through book reviews, publications and papers in scientific journals. While it is not yet possible to establish a direct and linear relationship between climate change and violent conflict, the revised literature indicates that competition for water and other natural resources in certain parts of Nigeria is increasing, and that the violent conflicts between Fulani herdsmen and farmers are increasing due to the dispute over access to water sources and grazing lands. Data analysis shows that in the study area there are $46.4 \%$ more deaths in the dry season (November to April) than in the rainy season (May to October). While there are still not enough elements to conclude that climate change is the primary cause of the conflict, the analysis reinforces the need, in certain contexts, particularly in developing countries with populations highly dependent on the primary sector of the economy, for the impacts of climate change to be seriously considered as a risk to human security.

\section{Keywords}

Climate change; Communal conflict; Nigeria; Fulani; Water.

\section{How to cite this article}

Furini, Gustavo (2019). "The influence of climate change on the escalating communal conflict between herdsmen and farmers: the case of the Fulani ethnic group in Nigeria". JANUS.NET e-journal of International Relations, Vol. 10, N.0 2, November 2019-April 2020. Consulted [online] on the date of the last visit, https://doi.org/10.26619/1647-7251.10.2.3 


\title{
THE INFLUENCE OF CLIMATE CHANGE ON THE ESCALATING COMMUNAL CONFLICT BETWEEN HERDSMEN AND FARMERS: THE CASE OF THE FULANI ETHNIC GROUP IN NIGERIA ${ }^{12}$
}

\author{
Gustavo Furini
}

\section{Introduction}

With the end of the Cold War, the definition of the concept of security came to have a broader understanding, incorporating new dimensions that surpassed the exclusively state bias (Tomé, 2012). In addition to military issues, social, economic, and environmental factors have incorporated the list of elements necessary to ensure world peace and security since the 1990s (Dannreuther, 2013; Sheehan, 2005; UNSC, 1992). In this context of broadening the understanding of security, the challenges posed by the scarcity of natural resources ${ }^{3}$ have also been considered (Homer-Dixon, 1994), in view of the recognition that the tensions generated around access and use of natural resources have the ability to unleash violent conflicts ${ }^{4}$ between different actors and groups, especially on an intrastate scale (Conca \& Wallace, 2012).

The challenges posed by environmental risks $^{5}$ stem mainly from society's misuse of natural resources, which has led to problems such as depletion of arable land, irreversible loss of biodiversity, pollution of soil, water and air (Dannreuther, 2013; Sheehan, 2005). Among the various negative impacts caused to the environment, we highlight climate change, which according to scientific evidence, results from the constant and growing emission of greenhouse gases into the atmosphere, especially due to the burning of fossil fuels (IPCC, 2013). Climate change has the capacity to widen social disparities through

1 The translation of this article was co-funded by Instituto Camões in the framework of the 1st International Conference on Conflict Resolution and Peace Studies. Text translated by Carolina Peralta.

2 Special issue of articles presented at the 1st International Conference on Conflict Resolution and Peace Studies that took place at UAL on the $29^{\text {th }}$ and $30^{\text {th }}$ of November 2018.

3 Natural or environmental resources are stocks of materials that exist in the natural environment, renewable and non-renewable, which, depending on their use, can be considered common goods or have economic value (WTO, 2010).

4 The understanding of violent conflict provided by The African Centre for the Constructive Resolution of Disputes (ACCORD, 2012) is used here, where lethal violence is used by the parties in the conflict to obtain the disputed resource, such as land or power.

5 The negative effects of climate change are normally taken as security "threats", however, it was decided to use the understanding given by SIPRI (2016) which considers that climatic changes are associated to "risks", since the climate crisis is a direct consequence of anthropogenic action. In addition, the challenges posed to mankind due to man-made actions on the environment over the last couple of centuries, as the case of climate change, fit the understanding of "Risk Society" proposed by Ulrich Beck (2016). According to the author, the processes of industrialization and modernization of the society have promoted environment imbalances, and the responses created by the environment seeking for a new momentum of balance have brought risks for social dynamics in general, including those related to security issues (Beck, 2017). 
worsening poverty, hunger, forced human mobility and greater difficulty in accessing natural resources, especially in developing countries, historically responsible for the lowest greenhouse gas contributions, but in contrast, those that are most vulnerable to climate change (IPPC, 2014).

Analyses of data collected from the atmosphere, land and ocean confirm that phenomena arising from climate change are already occurring, to a greater or lesser extent, throughout the planet, and such changes are associated with a major threat to social and economic stability of societies (IPCC, 2013). Observations and studies indicate that the western Sahel band, a region that includes the northern part of Nigeria, has been experiencing declining rainfall levels with longer drought periods and rising temperatures over the last decades (Assibong et al., 2017). This water variability has a negative impact on the availability of resources for people using the land as their livelihood, a scenario aggravated by the increasing pressure exerted by population growth in Nigeria ${ }^{6}$ (Eze, 2018).

The number of researchers examining the possible relationships between climate factors and non-state conflicts is growing (FOI, 2010), so there is a convergence that, in certain situations, the variation in water availability in primary sector dependent economies may influence violent conflicts, particularly in rural and pastoral societies in the African continent (IPCC, 2013; ACCORD, 2012). Given this, climate change has the ability to interfere, even indirectly, on the dynamics of violent conflicts, especially intra-state conflicts, since they can intensify poverty and aggravate economic crises, events that are already well documented as factors that directly influence the conflicts (IPCC, 2014).

And this is precisely what is happening in the central-eastern and northern regions of Nigeria, where it is possible to verify a gradual reduction in the availability of certain natural resources, especially water and arable land, which has been linked to records of rising temperatures and lower rainfall (Idowu, 2017; Okoli \& Atelhe, 2014; CCASTR, 2011). Such diminished access to natural resources is seen as a major cause of the escalation of non-state conflicts between herdsmen and farmers in central-eastern and northern parts of the country (Uze, 2018; Freeman, 2017).

In this context, this paper focuses on two objectives: i) initially, we sought to analyse based on the theory on the subject how the growing scarcity of natural resources, especially the scarcity of water, which has being aggravated by climate change according to scientific observation, applies to communal conflicts involving the Fulani ethnicity, especially in rural areas in the northern and central-eastern parts of Nigeria; and secondly, ii) it was verified how the seasonal variation in water availability, analysed from the rainfall index data in the rainy season (May-Oct) and the dry season (Nov-Apr), from 2010 to 2017, relates to the dynamics of communal conflicts involving the Fulani ethnicity in four Nigerian states (Plateau, Benue, Taraba and Nasarawa) located in the centraleastern zone of the country.

After revision of the theory, it was decided to take the approach proposed by Thomas Homer-Dixon (1994), which connects environmental scarcity to violent conflicts, especially those of ethnic origin at intrastate level. The work was carried out based on the case study analysis and information collected from primary sources (conflict database

6 According to World Bank data, the total population of Nigeria in 2018 was estimated at about 196 million. Available at: https://data.worldbank.org/country/nigeria. Accessed on 20/06/2019. 
provided by the $\mathrm{UCDP}^{7}$ ), and from the review of secondary sources (books, publications and papers in scientific journals).

Besides this introduction, the paper has four sections. The first part addresses the inclusion of environmental factors, especially climate change, in the broader understanding of post-Cold War security. The next section discusses the nexus between climate change and violent conflict, and examines how climate change can negatively affect the availability of natural resources, which in turn generates or exacerbates conflict. The third section addresses the communal conflict in Nigeria between Fulani farmers and herdsmen, with a view to identifying the influence of climate change on this conflict by reducing the availability of natural resources, especially water. The fourth part of this paper presents the case study that the interference of rain in violent, with fatal attacks involving the Fulani ethnic group in four Nigerian states. At the end of the document, the conclusion and references used are presented.

\section{The inclusion of climate change in the understanding of security}

Environmental issues have been formally on the international agenda since the late $1960 \mathrm{~s}$ and early 1970s, culminating in the Stockholm Conference in 1972, however, at that time central security issues were determined by the Cold War (Sheehan, 2005). The notion that humanity was causing irreparable damage to the environment and the fear of nuclear catastrophe were the main concerns of the environmental agenda at the time (ibid.). During the Cold War period, security concerns were directly related to state military action and thus, there was no room for discussion of issues such as environmental security (Dannreuther, 2013). Moreover, such a classic concept of state protection security lasted for more than three centuries, from the creation of Weber's notion of the state until the early 1990s (FOI, 2010).

However, the global changes and challenges that emerged on the international scene at the end of the last century have brought with it the need to include topics such as economics, demographics and the environment in order to have a better understanding of the new directions of security (Mathews, 1989). The exclusivism of the state-centric bias that had guided security institutions so far was not adequate to cope with the new challenges ahead (ibid.). Thus, the end of the Cold War allowed the emergence of interpretations other than those that favoured only the state approach, which enabled a broader understanding of security (Tomé, 2010). Such understanding has come to depend on the interaction between various factors and, in this list of new dimensions, the environmental issue and related themes, such as climate change, are included (ibid). As evidence of the change in the international scene, in January 1992 the United Nations Security Council presidency issued a note emphasizing that the end of wars and armed conflicts between states alone were not sufficient to ensure international security, admitting that social, economic, humanitarian and ecological issues have become potential sources of instability for security and peace (UNSC, 1992).

Faced with this scenario of transformation between the late 1980s and the early 1990s, the environmental theme became part of security studies, and exposed the need to formulate and develop theories and concepts with a view to delimiting the object of study (Sheehan, 2005). From this perspective, it is possible to highlight the concept of

7 Uppsala Conflict Data Programme (UCDP). 
environmental security, which, although its definition still causes heated debate until today (Soromenho-Marques, 2015), has been used to address the environmental risks that emerge from natural systems due to human interference (Dannreuther, 2013). Examples include misuse of natural resources, deforestation, disorderly land use, contamination of water and atmosphere, and climate change (Sheehan, 2005; HomerDixon, 1994). Anthropic activities began to interfere in natural processes in such a way that the "Risk Society" began to suffer from the consequences dictated by itself (Beck, 2016), strengthening the understanding that we are living in the Anthropocene ${ }^{8}$ period. Addressing the issue of environmental security raises the concatenation of methodological precepts of the environmental sphere with disciplines that traditionally address security issues, such as strategy and international relations (SoromenhoMarques, 2015).

Moreover, the discourses that address climate change tend to adopt the concept of "human security" whose origin is attributed to the Human Development Report, published by the UNDP in 1994 (FOI, 2010). The paper proposes an integrative concept and involves seven different dimensions of security: economic, personal, community, political, food, health and environmental (UNDP, 1994). This concept embraces a wide range of factors based on the understanding that conflicts will become more intense within nations, and not between them, mainly due to the lack of access to resources and socioeconomic disparities (ibid). In addition, as the concept evolves and consolidates, the fifth report of the Intergovernmental Panel on Climate Change (IPCC) has devoted an exclusive chapter to human security, addressing the risks posed by climate change, including an increased likelihood of violent conflict in areas with high levels of economic, social and environmental vulnerability (IPCC, 2013).

Acute insecurity situations such as hunger, conflict and socio-political instability almost always emerge from the interaction of multiple factors (Burke et al., 2015). However, there is growing scientific recognition that climate change could undermine human security as it undermines people's livelihoods, especially through diminishing reserves and access to natural resources, and can trigger violent conflict both locally and regionally (Raimi \& Jack, 2017). The consequences of climate change must be treated as an additional environmental element for human security, from the point of view of the state to the scale of the individual (ibid.), although there are few cases in the literature that explicitly address the relationship between climate change and security, these studies indicate the existence of a nexus (IPCC, 2013). However, it is crucial to note that the academics point out that the relationship between climate change and human security is mostly indirect, and consider that climate change has a catalytic effect in certain contexts of violent conflict (Penny, 2018; Raimi \& Jack, 2017; Buhaug, 2016; Uexkull et al., 2016; Burke et al., 2015; Salehyan, 2014; UNGA, 2009).

\section{Climate change, scarcity of natural resources and violent conflict}

In the 1990s, Thomas Homer-Dixon was one of the pioneers to relate problems of access to natural resources to security and violent conflict (Dannreuther, 2013). The author assumed that changes in the environment caused by humans, which have the ability to

8 The Anthropocene marks a time when the magnitude of human interference in the environment is such that society can be characterized as a geophysical force of global influence, capable of having negative impacts in various areas, including in terms of security (Dalby, 2017). 
directly affect not only the quality but also the quantity of natural resources, together with population growth and the unequal geographical distribution of natural resources, constitute the tripod of environmental scarcity (Homer-Dixon, 1994). The author argues that environmental scarcity can, under certain circumstances, disrupt security due to its ability to interfere with social, political and economic processes, and in weakened states, the rise in social tension caused by the scarcity of natural resources may culminate in escalating levels of intra-state violence (ibid.).

Although case studies have been able to document and link the degradation or unavailability of natural resources to the occurrence of violent conflict, the theory has been questioned on the basis of weaknesses in establishing a causal relationship (Dannreuther, 2013). The many variables in the social context, especially in economic and political terms, make it difficult to identify a causal link between variations in environmental availability and violent conflict (SIDA, 2018; SIPRI, 2016; Conca \& Wallace, 2012). However, the lack of quantitative studies that are statistically robust to confirm the direct link between environmental causes such as climate and violent conflict alone cannot be taken as a parameter to completely rule out any kind of influence (Burke et al., 2015; UNGA, 2009).

Moreover, the scientific community has recognized that environmental factors have the ability to exacerbate conflict indirectly through multiple forms, as they aggravate existing social, political and economic tensions (Penny, 2018; Freeman, 2017; IPCC, 2013; ACCORD, 2012; FOI, 2010; UNGA, 2009). It should also be considered that the difficulty encountered in demonstrating the existence of a direct and linear relationship between environmental issues and violent conflicts reinforces the idea that responsibility rarely falls under a single factor, but rather results from a succession of interconnected events (Raimi \& Jack, 2017; FOI, 2010). In terms of climate change, the difficulty in establishing this direct relationship is mainly due to the low probability of groups deciding to conflict simply because the heat has intensified or due to the decrease in the amount of rain, however, negative impacts from climate change such as drought and desertification can lead to violent conflict (Buhaug, 2016).

Each society's social and environmental vulnerability will determine whether the negative impacts of climate change will lead to conflict (Buhaug, 2016; Scheffran et al., 2012). In this regard, communities highly dependent on agriculture and livestock, located in poor countries with low climate response capacity, may be in conflict over the use of natural resources that have become scarce due to the effects of rising temperatures or falling rain levels (Buhaug, 2016; Theisen et al., 2011). On the other hand, a society located in a rich country whose resilience is based on technological development to adapt to change, as well as on the responsiveness of its public and private institutions, would hardly have to deal with violent conflict due to the negative effects of climate change (Salehyan, 2014; Theisen et al., 2011).

The question that must to be asked is not "whether" climate change influences violent conflict, but "when" and "how" it happens (Salehyan, 2014). In order to establish any link, the analysis should take into account three dimensions, namely: i) the geographical location at which the impact of climate change occurs (spatial dimension); ii) the period in which it takes place (temporal dimension) and; iii) the responsiveness of the population and institutions to cope with the situation of environmental stress (social dimension) (ibid.). All of these dimensions are interconnected and, in order to have a concrete interpretation of a specific situation in which these dimensions are acting together, the 
analysis must be focused on an individualized scenario, avoiding generalizations and the search for standards, reinforcing, once again, the importance of context analysis (ibid.).

Changes in the environment caused by climate change can undermine human security by reducing access to certain natural resources indispensable for the livelihoods of many societies, particularly in Africa (Raimi \& Jack, 2017; FOI, 2010; UNGA, 2009). The scarcity of natural resources and the dispute over their use, such as water, could trigger violent conflicts (ACCORD, 2012), therefore variations in rainfall rates, either with increasing or decreasing rainfall, will be responsible for increasing the risk of violent conflict in highly resource-dependent economies, particularly in rural societies in Africa (IPCC, 2014). Access to water is a serious problem for many African countries, both in quantity and quality (IPCC, 2013), hence, one of the challenges in climate change studies is to predict how the behaviour of rain and temperature rise patterns will occur, since, depending on these factors, there may be additional pressure on water sources and fertile land (FOI, 2010).

It should be noted that there is debate among those who argue that there is an increasing potential risk of conflict due to water scarcity, while others use statistical data to show that tensions around the availability of this natural resource usually end with negotiation and diplomacy, especially in cross-border disputes (ibid.). However, most studies emphasize that this agreements' scenario may not be the focus in the future, particularly in intra-state terms, as climate change can aggravate water scarcity in regions with fragile governments and without the institutional capacity to manage this type of dispute between local communities (SIPRI, 2016).

Figure 1. Relationship between drought (Palmer Drought Severity Index, from 2005 to 2014) and violent conflict (UCDP, from 1995 to 2014) in part of the African continent, with focus to Nigeria inner the red circle

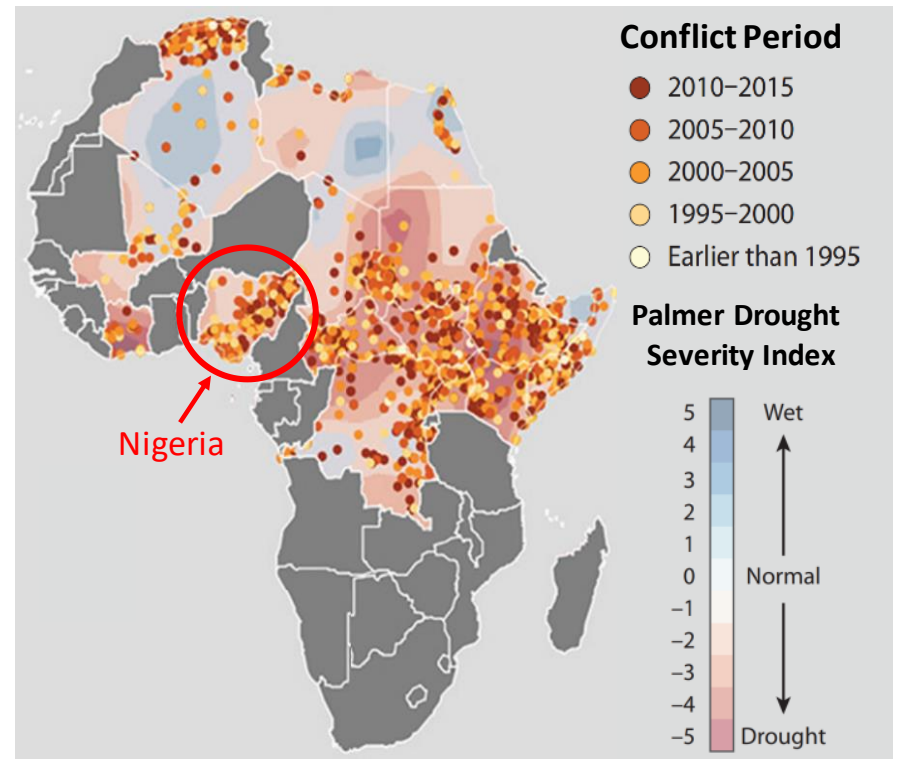

Source: Adapted from the original proposed by Koubi (2019)

Rising global temperatures are expected to induce and prolong periods of drought in many regions, particularly those already vulnerable to water scarcity, such as the African 
continent, which may influence intrastate conflicts (Koubi, 2019; Penny, 2018). Koubi's study (2019) related the drought indexes from 2005 to 2014, obtained through the Palmer Drought Severity Index (PDSI) ${ }^{9}$ method, with the data of conflicts in the African continent from 1995 to 2015 provided by the UCDP since 1995, as shown in Figure 1. Although conflict data have started a decade earlier than the drought index covers (PSDI), there is a strong concentration of violent conflict in drought-intensifying places, especially in sub-Saharan African countries, which also applies to Nigeria.

There is some consensus that climate variability on the African continent may lead to higher natural resource scarcity rates, which are the main livelihoods for a large part of the population (ACCORD, 2012). Increasing unavailability of natural resources essential for sustaining livelihoods will have a negative impact on human security, and the most devastating effects are projected for economies that are less able to adapt to such changes, which is essentially the case in developing countries (Uexkull et al., 2016). Regardless of the ongoing debate on the causal link between climate change and violent conflict, given the imminent threat to human security, it would make sense for the UN Security Council to take a more proactive stance on the matter (Scott \& Ku, 2018; Penny, 2018).

Given the Council's primary responsibility for maintaining peace and security globally, it does not seem coherent for the body to be oblivious to the discussion or to take a neutral stance in view of the extension of the phenomenon (ibid). The Security Council shows that its involvement is reactive and based on protocols on climate change issues, most likely due to resistance from some of its key members (Penny, 2018). Even in the face of this Security Council's weak participatory scenario, it is important to underline the position adopted by the Security Council with Resolution S/RES/2349/2017, in which it recognized, in a new way, climate change as a factor of instability regarding security, mainly due to interference with the availability of natural resources in Africa (UNSC, 2017). The Resolution addresses the conflicting situation that exists in the area of the Lake Chad Basin, the region in which northeast Nigeria is situated, and in its paragraph 26 recognizes that:

\begin{abstract}
"... the adverse effects of climate change and ecological changes among other factors on the stability of the Region, including through water scarcity, drought, desertification, land degradation, and food insecurity, and emphasises the need for adequate risk assessments and risk management strategies by governments and the United Nations relating to these factors... (UNSC, 2017:7)".
\end{abstract}

Thus, the absence of quantitative and statistical elements that prove the direct and linear relationship of the influence of environmental factors on violent conflicts cannot continue to serve as a pretext to play down their potential participation (Salehyan, 2014). And this appeal is even more relevant given the risks to human security caused by climate change in the least developed countries (IPCC, 2013). In light of the foregoing, the next

9 The PDSI was developed in the 1960 s and has been used to identify droughts from monthly temperature and precipitation data, as well as information on soil water retention capacity. It considers both the moisture received (precipitation) and the moisture stored in the soil, thus representing the potential moisture loss due to the influence of temperature (WMO \& GWP, 2016). 
section will address the role climate change plays in environmental scarcity in Africa, as well as its contribution to the worsening conflict between herdsmen and farmers in Nigeria who are highly dependent on the primary sector of the economy.

\section{Climate change, environmental scarcity and communal conflict in Nigeria: farmers vs. herdsmen}

Based on the concept of environmental scarcity proposed by Homer-Dixon (Figure 2), the perspective that the decrease in the quality and quantity of natural resources, aggravated by climate change, participates in the chain of events that may influence communal ${ }^{10}$ conflicts between herdsmen and farmers is used here. Such conflicts occur in several sub-Saharan African countries, presenting themselves as a challenge on a national and regional scale (Gbaka, 2014), therefore, the impact of Fulani action in Nigeria will be analysed in more detail.

Figure 2. Influence of climate change on natural resource scarcity and its relationship to communal conflicts

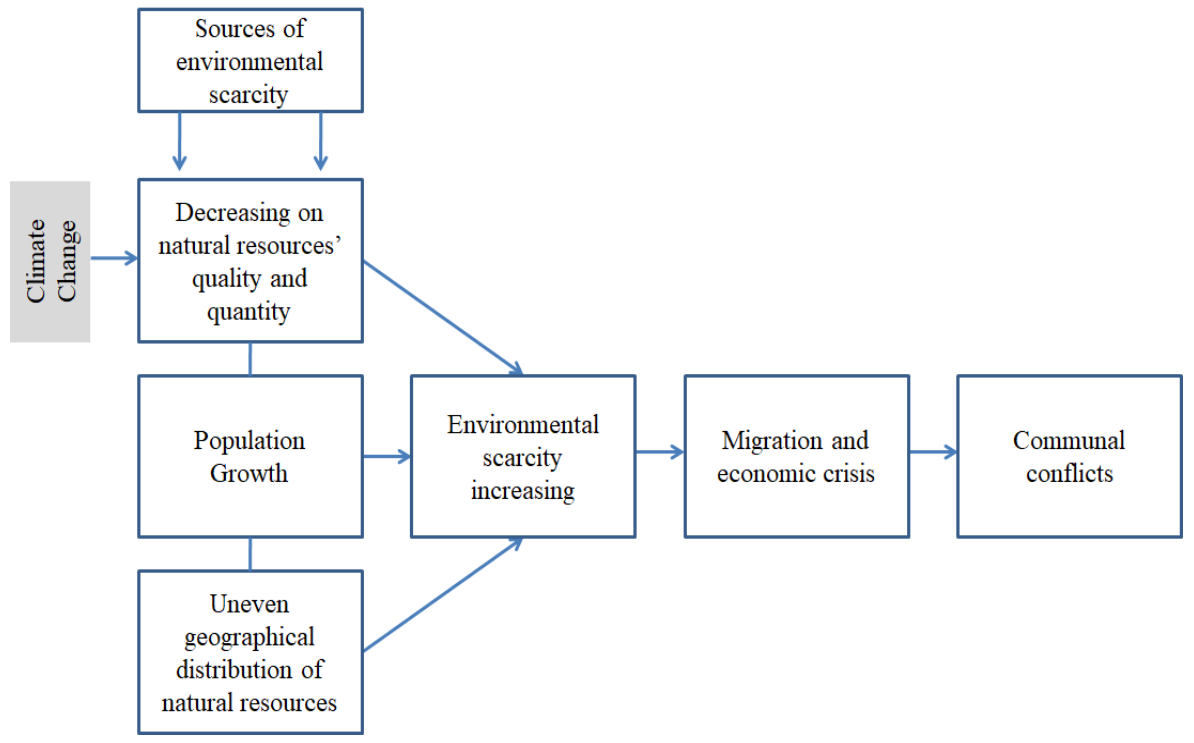

Source: Adapted from the original scheme proposed by Homer-Dixon (1994).

Africa is currently facing a series of problems arising from environmental degradation, and in the Sahel-influenced regions the greatest adversities are related to water availability, which is most visibly manifested by drought and desertification, and the negative effects are accentuated by climate change (IPCC, 2013). In addition, countries on the African continent are especially vulnerable to climate change because of their low

10 As defined by the UCDP (2016), communal conflicts are non-state and occur between groups that share lines of identity such as religion, ethnicity or belonging to the same clan or tribe. They are not permanently structured groups for combat, but sometimes they organize themselves to engage in violent conflict, and their scope tends to be intrastate. However, asserting that communal identity refers only to ethnic or religious identity may give the term a less flexible character, so ACCORD (2012) stresses that the main identification may be based on livelihood disputes, hence, communal conflicts also involve those that occur between herdsmen and farmers. 
adaptive capacity and projected negative impacts (ibid). The scarcity of natural resources has caused, for example, a series of disputes between farmers and herdsmen, as the maintenance of rural communities' livelihoods depends directly on access to such resources (Ahmadu, 2018). Central to these communal conflicts is the search for the defence of material resources, a struggle that is most evident from the scarcity of water, which is reflected, among other forms, through desertification (ibid.).

The insecurity of the natural resources necessary for the livelihoods of rural populations is pressing in Nigeria (CCASTR, 2011). It has been proved that the average temperature in Nigeria has increased $1.1^{\circ} \mathrm{C}$ since 1900 to today, and the world average temperature has risen $0.74{ }^{\circ} \mathrm{C}$ from 1860 to the present day (Akpodiogaga-a \& Odjugo, 2010). In addition, studies in the mid-1980s already pointed to a drought trend in Nigeria as a result of decreasing rainfall in the central-eastern and northern part of the country (Adefolalu, 1986). Currently, areas located in northern Nigeria have undergone a profound desertification process (Ahmadu, 2018; Nwokeoma \& Chinedu, 2017; Assibong et al., 2017), and livestock-dependent populations are directly affected, so there is an increase in population flows, especially livestock farmers, towards the centre of the country (Freeman, 2017).

West Africa, in particular Nigeria, has experienced a considerable increase in intrastate conflicts since the early 1990s, and they have been particularly worrying since the $2000 \mathrm{~s}$ with the intensification of clashes between farmers and herdsmen over natural resources, whose scarcity tends to increase, aggravated by climate change (Okoli \& Atelhe, 2014). Conflicts between farmers and herdsmen are common in almost all parts of Nigeria, and overcoming them is a major challenge for economic development, food security and the sustainability of agrarian communities (Ukamana et al., 2017). As stated earlier, the likelihood that climate effects will lead to violent conflict depends on the context, as well as on the likelihood that communal conflicts will occur in areas of natural resource scarcity (Vestby, 2018). This situation is particularly worrisome in regions where the government is not present, such as in areas where conflicts between farmers and herdsmen are triggered in the lands of central and northern Nigeria (ibid.). Tracing causality lines between climate change and conflict requires caution, as it cannot be gauged indistinctly that citizens begin to fight automatically over simple temperature increases (Buhaug, 2016; Odoh \& Chigozie, 2012).

The literature shows that the conflict between farmers and herdsmen is recurrent in Nigeria and the interaction between both dates back to ancient times, especially the Fulani group of herdsmen, whose entry into the areas that currently form the Nigerian territory dates back to the fourteenth century (Ahmadu \& Ayuba, 2018). Both the religious and ethnic biases of tensions between mostly Muslim Fulani herdsmen and predominantly Christian farmers are important in determining this communal conflict, exacerbated by scarcity of natural resources and desertification (IEP, 2017). Nigeria is can be considered a divided country and intra-state violent conflicts can quickly lead to communal conflict of an ethnic-religious dimension, as ethnic groups usually support their "lineage" in violent struggle, on the premise that group rights to which they belong should prevail (Akov, 2017).

The Fulani are a livestock raising nomadic ethnic group of about 20 million people scattered throughout West and Central Africa (Bamidele, 2018), but only a small part is involved in violent attacks in Nigeria (IEP, 2017). The Fulani ethnic group owns $90 \%$ of the country's herd, with livestock accounting for a third of the primary sector's GDP 
(Bamidele, 2018; Abbass, 2012). Problems related to water scarcity and desertification in the Sahel caused a change in the behaviour of Nigerian herdsmen, who began to look for alternatives to maintain their lifestyle in more central areas of the country (Abugu \& Onuba, 2015). The alarming desertification situation across the Sahel region has forced Fulani herders to drive their cattle to pastures located in the central and central-eastern parts of the country, also known as the Middle Belt (ibid). Fulani herdsmen have transformed the central regions of the country into permanent residence and no longer temporary residence, as was common during travels between the northern and southern extremes of Nigeria, which contributes to exacerbating the conflicts with the farmers (Akov, 2017; Abugu \& Onuba, 2015; Okoli \& Atelhe, 2014).

Conflicts between these two groups stem from competition and a desperate struggle for survival and livelihood in an environment marked by insecurity and scarcity of natural resources, a situation exacerbated by climate change (Okoli \& Atelhe, 2014; Odoh \& Chigozie, 2012; Abbass, 2012). The study by Okoli \& Atelhe (2014) identified that climate change aggravates the scenarios of water availability (desertification and drought), and, as a result, increases the migratory flow of herdsmen across Nigerian territory. The high levels of violence that has involved the Fulani ethnic group since the end of the last decade must be highlighted, and UCDP data show that this ethnic group was involved in hundreds of conflicts in Nigeria from January 2010 to December 2017, with 3,334 casualties. Most of the attacks took place in inland villages, particularly in four centrally located states (Benue, Plateau, Taraba and Nasarawa), where there were 3,085 deaths. Specifically in these four states, the Fulani came into violent conflict with groups of different ethnicities, namely: Birom, Tiv, Agatu, Eggon, Tarok, Jukun, Irigwe, Mambila, Atakar, and Bwatiye.

However, it is important to point out that in relation to the significant number of cases of fatal victims by violent attacks perpetrated by the Fulani, these acts may have a very different origin and nature, so although the dispute over natural resources is of great importance today, it should not be taken as a single factor (Chinwokwu, 2017). Criminal activities are diverse and may involve armed robbery, murder, looting, kidnapping, and destruction of communities and churches (ibid.). Most episodes involving criminal acts perpetrated by the Fulani, especially the heinous ones, are not even investigated by the government security agencies of Nigeria (ibid.). Moreover, herdsmen hardly ask permission to move or stay in any community, which in local culture is seen as sufficient affront to generate serious conflict (Bamidele, 2018). Sectors of Nigerian society criticize the actions of President Muhammadu Buhari, who, because of his belonging to the Fulani ethnic group, seems to act in a conniving manner regarding the criminal acts performed by the ethnic group to which he belongs (ibid.).

\section{Influence of the rain regime on the dynamics of the communal conflict involving the Fulani ethnicity}

In this section is presented, from a case study, how water availability, strongly marked by seasons, can be related to death events in the communal conflict between herdsmen and farmers in four Nigerian states (Benue, Plateau, Taraba and Nasarawa) in the period from January 2010 to December 2017. In these states, located in the central-eastern part of the country, the rainfall regime is marked by the presence of two distinct and well-defined seasons, rainy (May to October) and drought (November to March). 


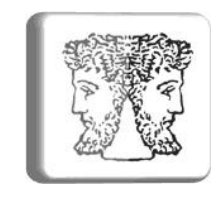

\subsection{Methodology used}

As a way of approaching the problem, the hypothetical-deductive method was adopted from a case study, which took as premise temporal and spatial criteria for the collection, processing and analysis of information. The database on violent attacks on the African continent provided by the Uppsala Conflict Data Program (UCDP), specifically Georeferenced Event Dataset (GED) Global Version 19.1 ${ }^{11}$ was used. For the purpose of meeting the proposed objectives, only information on violent conflicts with deaths in Nigeria involving the Fulani ethnicity was selected.

Regarding the time frame, the period from January 2010 to December 2017 was determined according to the escalation of events with deaths from 2010. However, it is important to highlight that the UCDP database shows sparse violent events involving the Fulani ethnicity in Nigeria since the 1990s, with a progressive increase in their frequency from the early years of this century. Thus, the data indicate that the conflict has not only been consolidated, but that they have also spread geographically from 2010 onwards. As for the number of deaths, these were based on the best estimate ${ }^{12}$ according to the UCDP categorization.

Regarding the spatial area, were analysed the events that occurred in four states in the central-eastern region of Nigeria (Plateau, Benue, Taraba and Nasarawa), the "study area" of this paper, a choice that is justified given that $92.5 \%$ of fatalities were concentrated in the period (Jan-2010 to Dec-2017), or 3,085 deaths out of a total of 3,334 fatalities (Figure 3). Moreover, the concentration of violent attacks in this part of the country corroborates the information collected in the literature, thus identifying a trend of migration from the north towards the central-eastern region of the country in search of places with greater availability of water and grassland. Events with fatalities were located on the map from the latitude and longitude information provided by the UCDP database. It should be noted that there were cases where different events involving deaths occurred in the same locality at different dates over the analysed period, in which cases the locations of the events overlapped on the map, which in these cases were identified by a single point.

In order to verify the existence of a relationship between fatalities and the occurrence of rainfall, since the variation in precipitation levels has the ability to contribute to greater or lesser water scarcity, monthly data of accumulated rainfall in millimetres were used in 15 locations ${ }^{13}$, as shown in Figure 4. With the accumulated rainfall data per location, monthly rainfall was averaged for each of the four Nigerian states from January 2010 to December 2017, for a total of 96 months. Finally, a graph was generated combining the information of the monthly rainfall index with the month of the occurrence of fatalities, according to Figures 6 to 9 .

${ }^{11}$ Available for downloading at https://ucdp.uu.se/downloads/. Accessed on 20/05/2019.

12 According to the UCDP Georeferenced Event Dataset Codebook Version 19.1, available for downloading at https://ucdp.uu.se/downloads/ged/ged191.pdf. Accessed on 20/05/2019.

13 Rainfall data used available for downloading at https://www.worldweatheronline.com. Accessed on $15 / 05 / 2019$. 
Figure 3. Area of study and location of conflict with fatalities

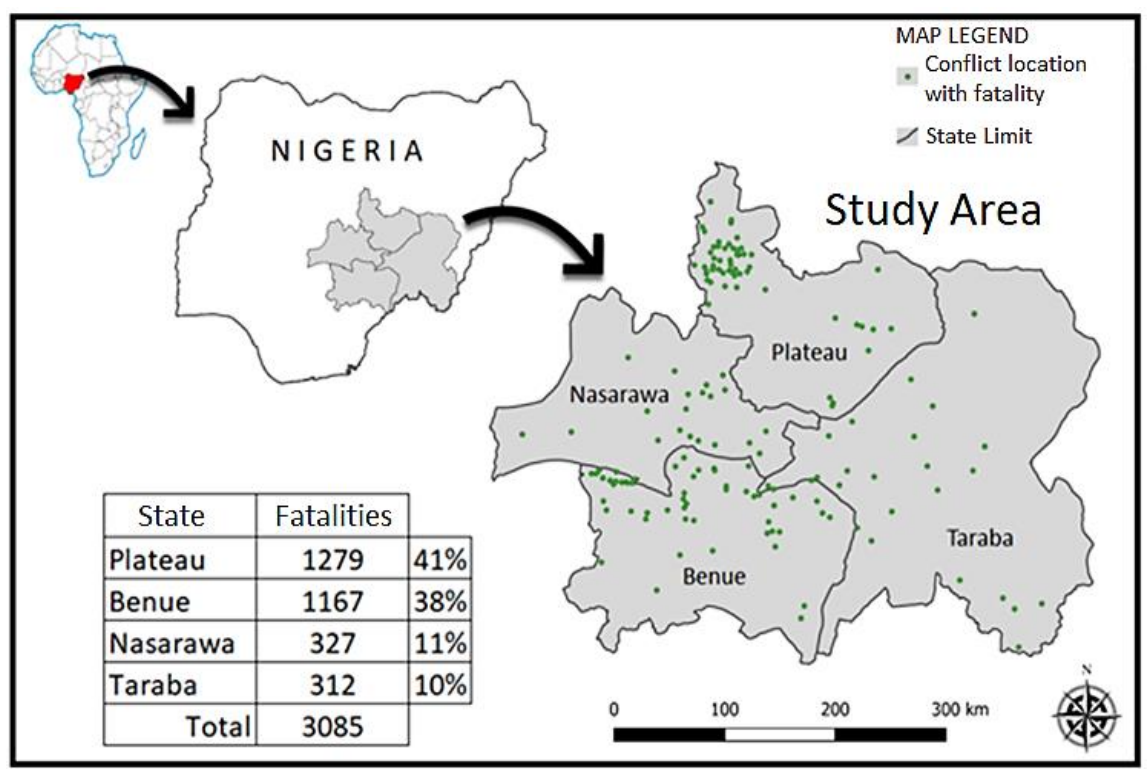

Source: Author

Regarding the tools used to verify data and generate products, spreadsheet analysis and editing software were used, also to make graphs and tables. Software was also used in GIS platform (Geographic Information System) for spatial data analysis and map production.

Figure 4. Location of rainfall data collection points in the Study Area

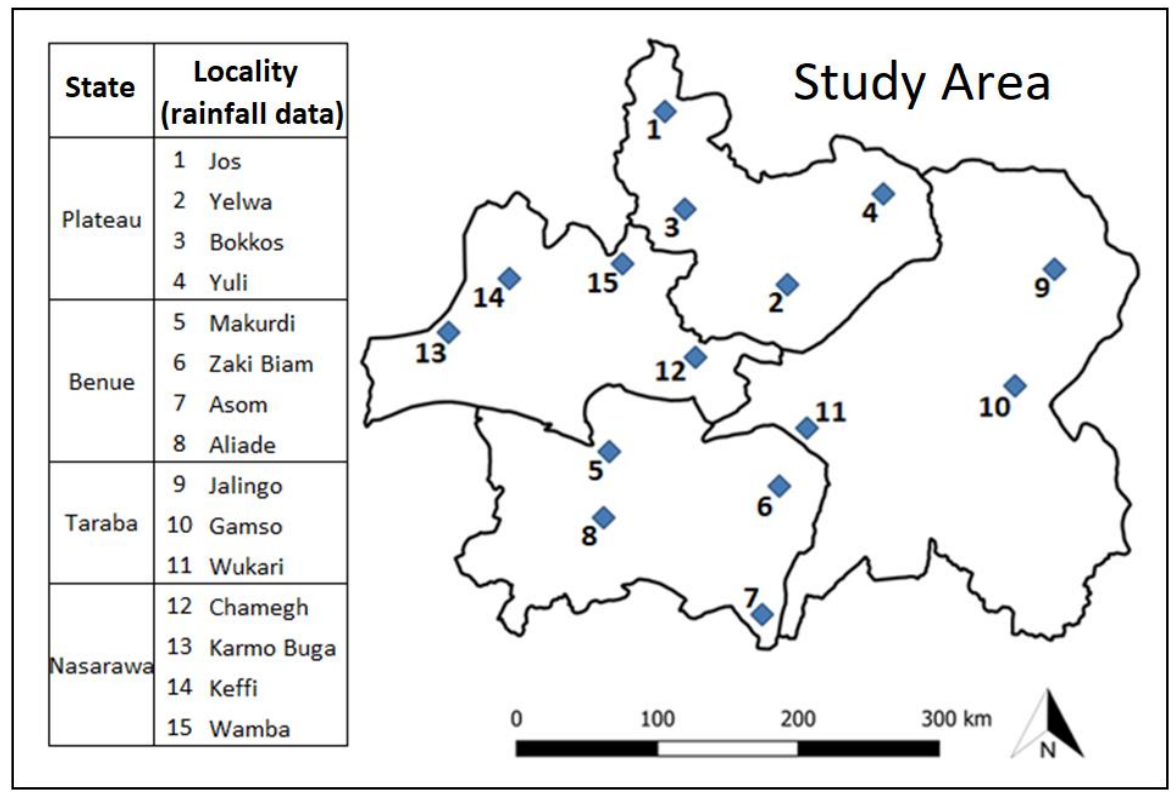

Source: Author 


\subsection{Results}

The analysis of the data shows, in the study area, that $46.4 \%$ more deaths in communal conflicts involving the Fulani ethnicity occurred in the dry season (November to April) than in the rainy season (May to October), as shown in Figure 5.

Figure 5. Distribution of deaths by time of year in the study area

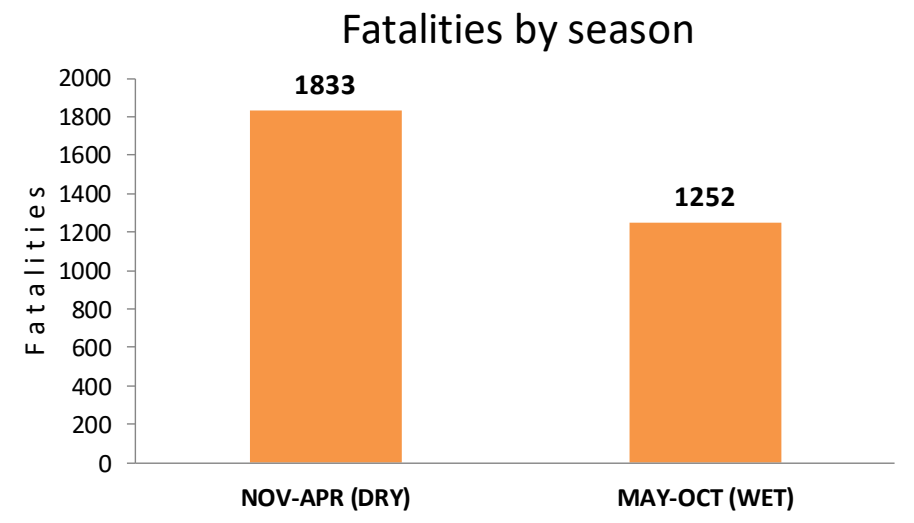

Source: Author

Regarding the distribution of deaths over the months from January 2010 to December 2017, we sought to verify the existence of a relationship between higher or lower precipitation rate with higher or lower number of fatalities. Figures 6 to 9 graphically represent the monthly average rainfall distribution with the number of deaths over the entire period analysed in each state of the study area.

Figure 6. Relationship between fatalities and rainfall (Plateau)

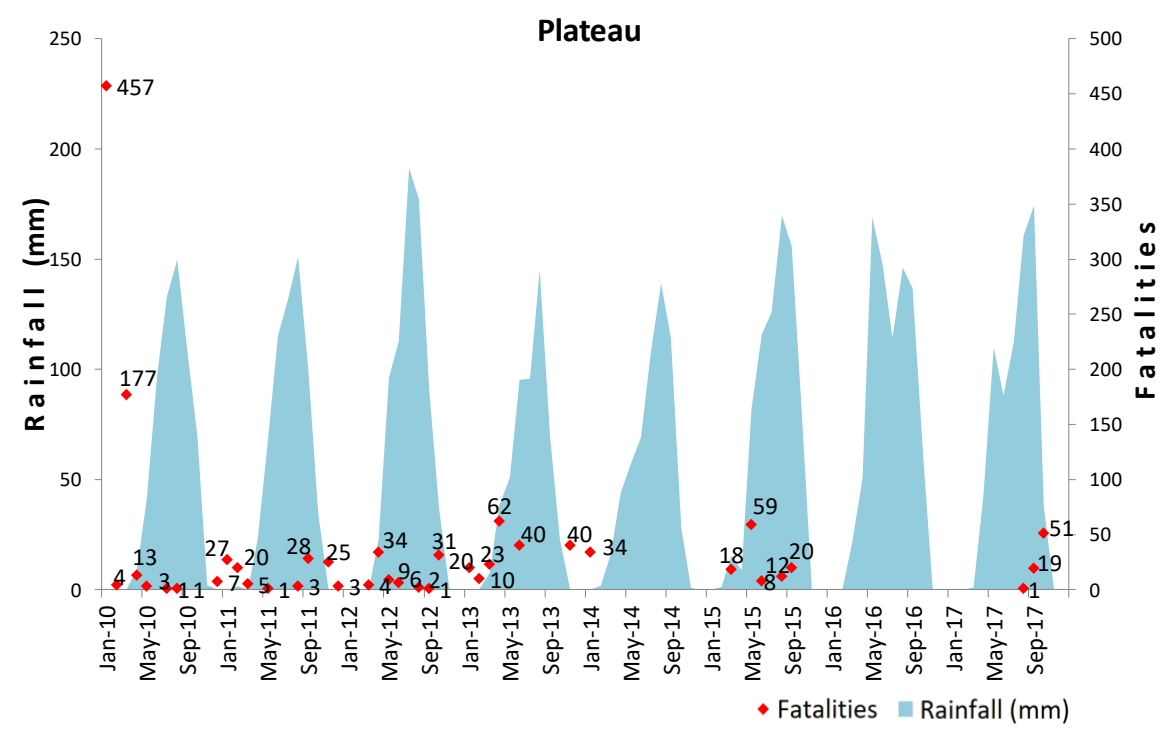

Source: Author 
Figure 7. Relationship between fatalities and rainfall (Benue)

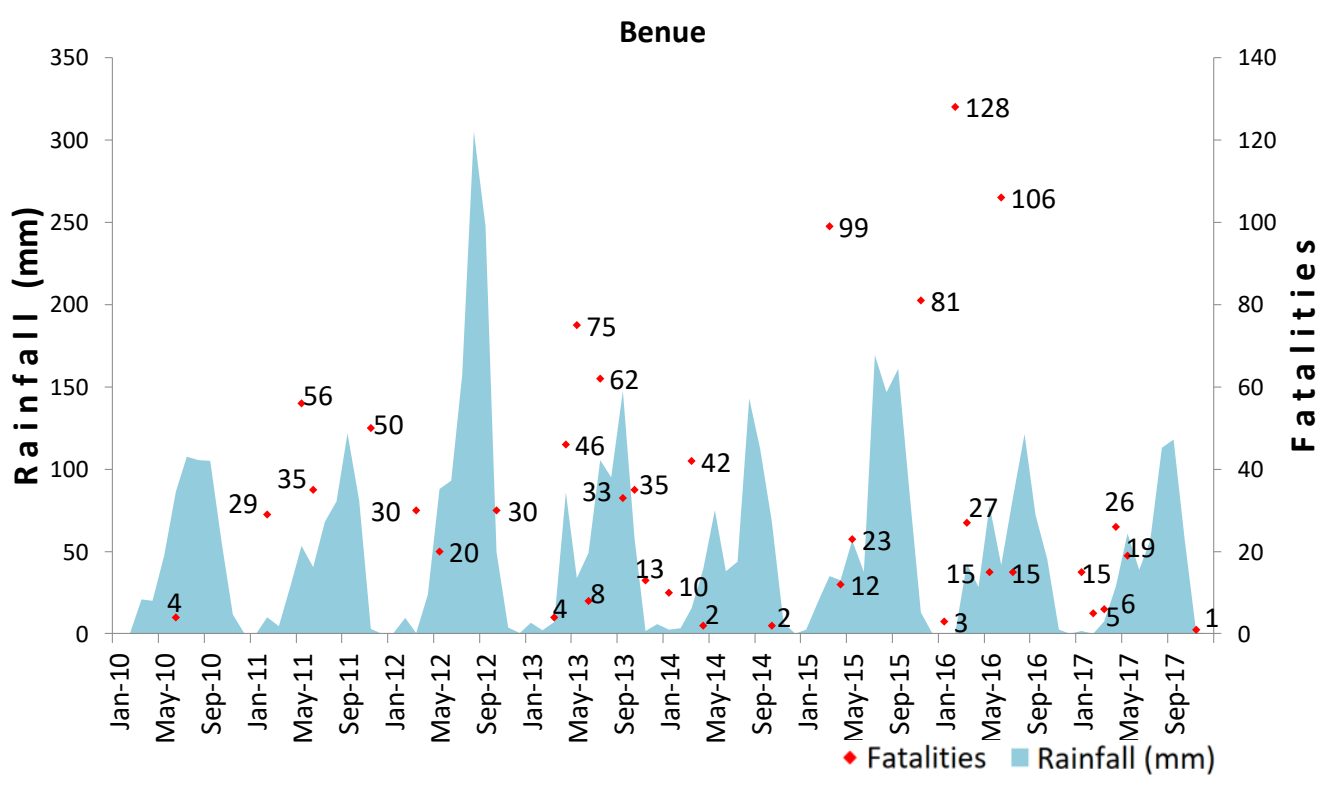

Source: Author

Figure 8. Relationship between fatalities and rainfall (Nasarawa)

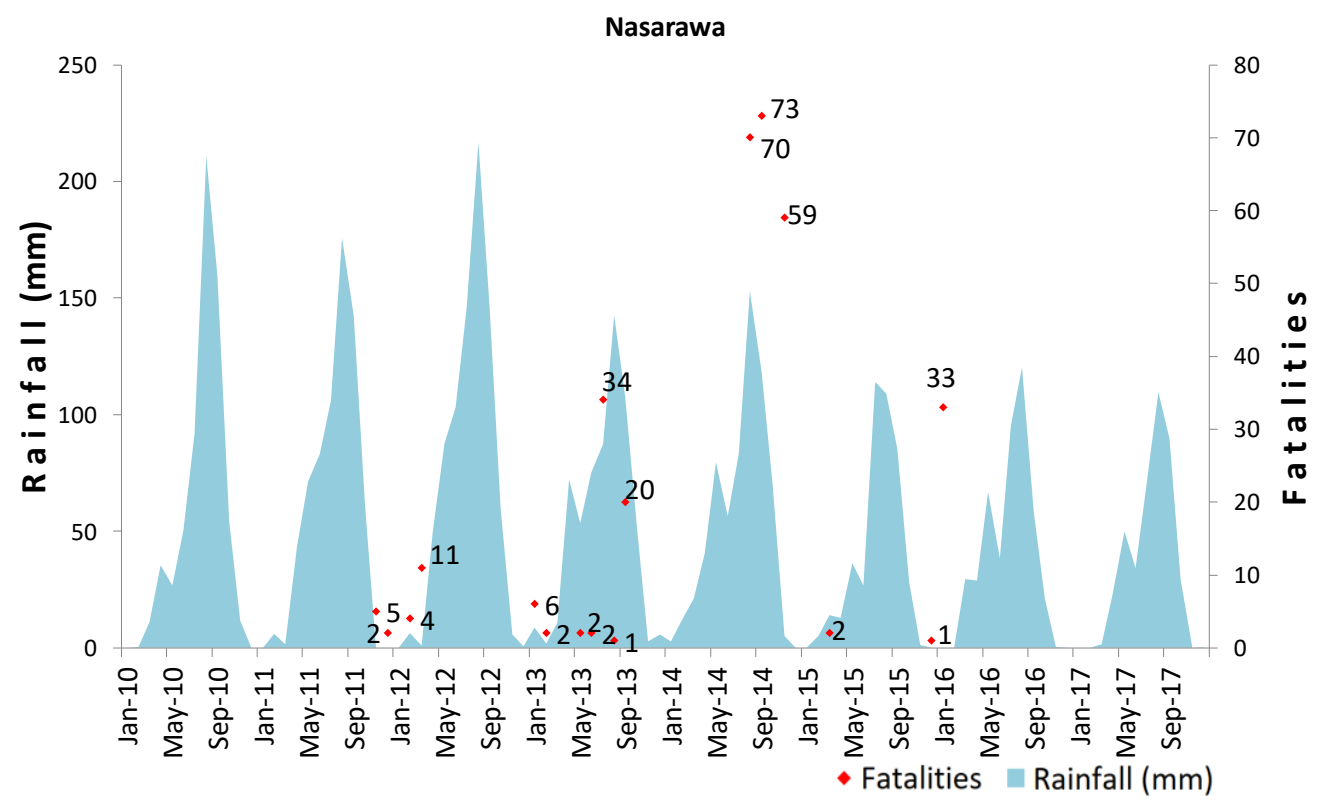

Source: Author 
Figure 9. Relationship between fatalities and rainfall (Taraba)

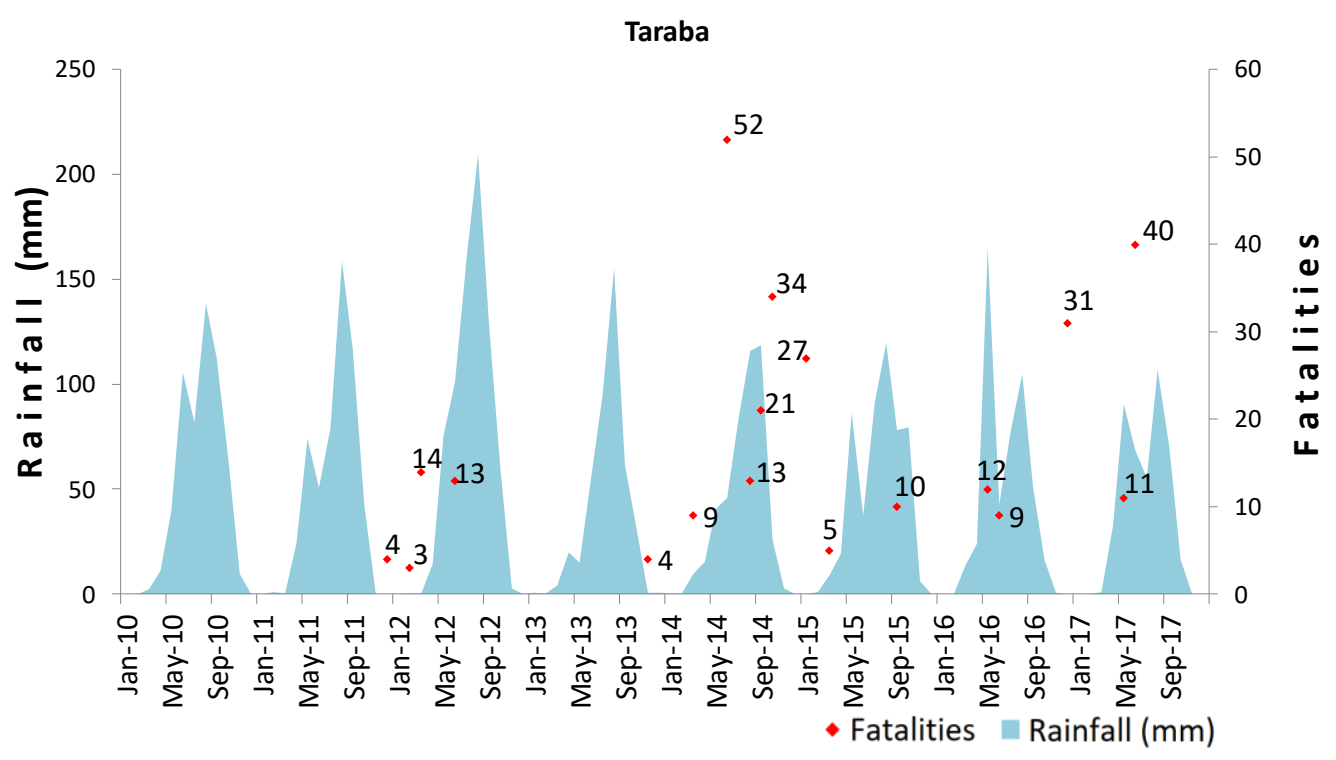

Source: Author

Although there is a higher propensity (46.4\%) of conflict with deaths occurring during the dry season (November to April), it is not possible to establish a cause-effect relationship between less rainfall and fatalities, nor to state that these attacks occurred exclusively due to the dispute over natural resources. However, it is important to highlight that the study area is comprised in the region of Nigeria where Adefolalu (1986) had already identified a lower tendency for precipitation in the dry months, especially in the central regions of the country, comprised by the parallels $7 \mathrm{~N}$ to $9 \mathrm{~N}$. Analysis of the rainfall data over the 8 years of the series (Jan 2010/Dec 2017) shows that from December to February there is virtually no rainfall, and the average annual rainfall was always below 1,000 mm, which was expected in this part of Nigeria.

\section{Conclusions}

To explain the reason behind communal conflicts, it is necessary to know the context of the object of study as broadly as possible, and then to draw conclusions, even if succinct at first, since conflicts are usually surrounded by a complex network of events. In the present case, the literature review allowed us to identify, from several studies in different sources, that the availability of natural resources, especially water and farmland, is worsening in regions of Nigeria. Scientific studies have shown that climate change plays an important role in worsening drought and desertification, which contributes to the forced displacement of rural populations from the north to the central-eastern region expecting to find natural resources to maintain their lifestyles. Therefore, although climate change cannot be considered, so far, as an element that acts directly and linearly in the origin of conflicts, its impact is relevant and its interference should be considered in communal conflicts, such as between the Fulani herders and the farmers in Nigeria. 
Therefore, it is possible to conclude that Homer-Dixon's (1994) chosen theoretical approach adequately and satisfactorily applies to the reality of the researched context.

Based on the analysis carried out in the study area during the last section of this paper, even though it was not possible to draw a dependence relationship between the higher occurrence or absence of rain with deaths caused by violent conflicts, it is possible to infer that there is a $46.4 \%$ higher probability of fatalities occurring in the drought-marked period of the year (November to May). Therefore, the causes of this greater propensity for fatal victims to occur in violent conflicts involving the Fulani in the months with or without rainfall can be worsened by the decrease in water availability due to global climate change, which is a topic for further research.

Finally, in an attempt to contribute to the resolution of the communal conflict discussed here, it is proposed that once it is understood and internalized that the impacts of climate change are a risk to human security in the country, Nigerian policy makers should strongly consider all climate change adaptation alternatives available beyond what is already underway. This is true not only for locally funded initiatives, but above all, more support and resources should be sought from more developed countries to expand investment in adaptation projects.

Not only Nigeria, but other countries located in sub-Saharan Africa should raise their demands during multilateral climate rounds, in particular under the United Nations Framework Convention on Climate Change (UNFCCC). This is because the Green Climate Fund, approved by all Parties to the Convention, should receive from developed countries $\$ 100$ billion in annual funding to finance adaptation and mitigation projects in poor countries. However, so far less than $2 \%$ of the total that should have been deposited over this decade has reached the Fund's coffers.

\section{References}

Abbass, I. M. (2012). No retreat no surrender conflict for survival between Fulani pastoralists and farmers in northern Nigeria. In European Scientific Journal. Vol. 8, no. 1.

Abugu, S. O.; Onuba, C. O. (2015). Climate change and pastoral conflicts in the middle belt and south-east Nigeria: implication on human resource of the regions. In Global Journal of Human Resource Management. Vol. 3, no. 5.

ACCORD, The African Centre for the Constructive Resolution of Disputes (2012). Climate change and conflict: Conflict-sensitive climate change adaptation in Africa.

Adefolalu, D. O. (1986). Rainfall Trends in Nigeria. In Theoretical and Applied Climatology. Vol. 37.

Ahmadu, H. J. (2018). Analysis on Some Causes and Consequences of North-South Migration of Fulani Pastoralists in Nigeria. In International Journal of Innovative Research \& Development. Vol. 7, no. 3.

Ahmadu, H. J. \& Ayuba, H. (2018). The role of group solidarity in conflict between farmers and Fulani pastoralists: A case study of Northern Nigeria. In African Journal of Political Science and International Relations. Vol. 12, no. 3. 
Akov, E. T. (2017). The resource-conflict debate revisited: Untangling the case of farmerherdsman clashes in the North Central region of Nigeria. In African Security Review. Vol. 26, no. 3 .

Akpodiogaga-a, P.; Odjugo, O. (2010). General Overview of Climate Change Impacts in Nigeria. In Journal of Human Ecology. Vol. 29, no. 1.

Assibong, P. A.; Chidozie, F.; Bakare, J. (2017). The politico-socio-economic consequences of climate change in Nigeria. In Covenant University Conference on eGovernance in Nigeria (CUCEN2017).

Bamidele, S. (2018). 'Bandidos de Terras' ou 'Grileiros': conflitos sangrentos e incessantes entre pastores Fulani e fazendeiros locais na Nigéria. In Revista Brasileira de Estudos Africanos. Vol. 3, no. 6.

Beck, U. (2016). A sociedade de risco mundial: em busca da segurança perdida. Edições 70: Lisbon.

Beck, U. (2017). A metamorfose do mundo. Edições 70: Lisbon.

Buhaug, H. (2016). Climate Change and Conflict: Taking Stock. Peace Economics. In Peace Science and Public Policy. no. 22 (4).

Burke, M.; Hsiang, S. M.; Miguel, E. (2015). Climate and Conflict. In Annual Review of Economics. no.7.

CCASTR, Climate Change Adaptation Strategy Technical Reports (2011). Building Nigeria's Response to Climate Change (BNRCC) Project.

Chinwokwu, E. C. (2017). Glamorization of Fulani herdsmen's criminality and its implications on national security in Nigeria. In Online Journal of Arts, Management and Social Sciences (OJAMSS). Vol.2, no. 2.

Conca, K. \& Wallace, J. (2012). Environment and peacebuilding in war-torn societies: Lessons from the UN Environment Programme's experience with post-conflict assessment. In Assessing and Restoring Natural Resources in Post-Conflict Peacebuilding. Jensen, D. \& Lonergan, S. (Ed.). London: Earthscan.

Dalby, S. (2017). Anthropocene Formations: Environmental Security, Geopolitics and Disaster. In Theory, Culture \& Society. Vol. 34 (2-3).

Dannreuther, R. (2013). International Security: the contemporary agenda. $2^{\text {nd }}$ Ed. Cambridge: Polity Press.

FOI, Swedish Defence Research Agency (2010). On Connecting Climate Change with Security and Armed Conflict. Department of Defence Analysis. Stockholm.

Freeman, L. (2017). Environmental change, migration, and conflict in Africa: A critical examination of the interconnection. In Journal of Environment and Development. Sage Publications.

Gbaka, E. (2014). Managing Conflict Between Farmers and Pastoralists in Benue State, Nigeria. In Peace Trends. Vol. 2, no.3.

Homer-Dixon, T. F. (1994). Environmental Scarcities and Violent Conflict: Evidence from cases. In International Security, Vol. 19, no. 1. 
Idowu, D. L. (2017). Causes, consequences and resolution of environmental conflict in Nigeria. In International Journal of Social Science and Economic Research. Vol. 02, no. 01.

IEP, Institute for Economics \& Peace (2017). Global Terrorism Index.

IPCC, Intergovernmental Panel on Climate Change (2013). The Physical Science Basis. Fifth Assessment Report.

IPCC, Intergovernmental Panel on Climate Change (2014). Climate Change 2014: Impacts, Adaptation, and Vulnerability. IPPC Working Group II.

Koubi, V. (2019). Climate Change and Conflict. In Annual Review of Political Science. Vol. 22.

Mathews, J. T. (1989). Redefining Security. In Foreign Affairs. Spring 1989.

Nwokeoma, B. N. \& Chinedu, A. K. (2017). Climate Variability and Consequences for Crime, Insurgency in North East Nigeria. In Mediterranean Journal of Social Sciences. Vol. 8, no.3.

Odoh, S.I. \& Chigozie, C. F. (2012). Climate change and conflict in Nigeria: a theoretical and empirical examination of the worsening incidence of conflict between Fulani herdsmen and farmers in northern Nigeria. Arabian Journal of Business and Management Review (OMAN Chapter). Vol. 2, no.1.

Okoli, A. C. \& Atelhe, G. A. (2014). Nomads against Natives: A Political Ecology of Herder/Farmer Conflicts in the Nasarawa State, Nigeria. In American International Journal of Contemporary Research. Vol. 4, no. 2.

Penny, C. K. (2018). Climate change as a 'threat to international peace and security'. In Climate Change and the UN Security Council. Scott, S. V. \& Ku, C. (Ed.). Cheltenham: Edward Elgar Publishing.

Raimi, L. \& Jack, J. T. C. B. (2017). How does climate change pose human security risks in the Niger delta? Implication for policy makers. In Maiduguri Journal of Arts \& Social Sciences. Vol. 14.

Salehyan, I. (2014). Climate change and conflict: Making sense of disparate findings. In Political Geography.

Scheffran, J.; Brzoska, M.; Kominek, J.; P. Link, M.; Schilling, J. (2012). Climate change and violent conflict. In Science. Vol. 336.

Scott, S. V. \& Ku, C. (2018). The UN Security Council and global action on climate change. In Climate Change and the UN Security Council. Scott, S. V. \& Ku, C. (Ed.). Cheltenham: Edward Elgar Publishing.

Sheehan, M. (2005). International Security: An analytical survey. Boulder: Lynne Rienner Publishers.

SIPRI, Stockholm International Peace Research Institute (2016). Climate-related security risks: towards an integrated approach. Stockholm.

Soromenho-Marques, V. (2015). Segurança Ambiental. In Enciclopédia de Direito e Segurança. Bacelar Gouveia, J. \& Santos, S. Coimbra: Almedina. 
Theisen, O. M.; Holtermann, H.; Buhaug, H. (2011). Climate Wars? In International Security. Vol. 36, no. 3.

Tomé, L. (2010). Security and security complex: operational concepts. In JANUS.NET ejournal of International Relations, No. 1, Autumn.

UCDP, The Uppsala Conflict Data Program (2016). Non-State Conflict Codebook. Version 2.5 .

Uexkull, N. V.; Croicu, M., Fjelde, H.; Buhaug, H. (2016). Civil conflict sensitivity to growing-season drought. Proceedings of the National Academy of Sciences of the United States of America - PNAS. no. 113 (44).

Ukamana, D. M. et al. (2017). Livelihood issues in herdsmen-farmers' conflict among farming communities in Kogi State, Nigeria. In African Journal of Agricultural Research. Vol. 12, no. 24.

UNDP, United Nations Development Programme (1994). Human Development Report 1994. New York: Oxford University Press.

UNGA, United Nations General Assembly (2009). Climate change and its possible security implications, Report of the Secretary-General. Sixty-fourth session. A/64/350.

UNSC, United Nations Security Council. (1992). S/23500. Note by the President of the Security Council. New York.

UNSC, United Nations Security Council. (2017). Resolution 2349. Adopted by the Security Council at its 7911th meeting, on 31 March 2017. New York.

Vestby, J. (2018). Climate, development, and conflict: Learning from the past and mapping uncertainties of the future. Ph.D. thesis. Department of Political Sciences, Faculty of Social Sciences, University of Oslo.

WMO, World Meteorological Organization \& GWP, Global Water Partnership (2016). Handbook of Drought Indicators and Indices. Geneva.

WTO, World Trade Organization (2010). World Trade Report 2010: Trade in Natural Resources. Geneva. 


\section{EUROPEAN UNION, RUSSIA AND THE MH17 CASE: STRATEGIC NARRATIVES' ANALYSIS (2014-2019)}

Paulo Ramos

paulocamoesramos@gmail.com

Master degree student in International Relations at the School of Economics and Management, University of Minho, Braga, Portugal and holder of a Bachelor Degree in Communication Sciences from the University of Porto. His research interests include EU-NATO relations with Eastern European countries, including Russia.

Alena Vieira d4215@eeg.uminho.pt

Integrated member of the Research Centre in Political Science (CICP) and Professor of the Department of International Relations and Public Administration, School of Economics and Management, University of Minho, Portugal. She has a Ph.D. in Political Science from the University of Erlangen-Nuremberg (Germany) and was Visiting Researcher at the Finnish Institute of International Affairs, at the Institute for Strategic and International Studies (Lisbon), and at the Catholic University of Leuven. She received scholarships and research grants from the Chair Inbev-Baillet Latour; Hanns-Seidel-Stiftung; Haniel-Stiftung; Compania di San Paulo, Riksbanken Jubileumsfond and Volkswagen-Stiftung foundations, as well as from the Foundation for Science and Technology. Her book 'Russland, Belarus und die EU-Osterweiterung' was published by Ibidem-Verlag, and her articles were published in the Europe-Asia Studies, Post-Soviet Affairs, EIOP Cambridge Review of International Affairs, and International Spectator journals, among others. Alena Vieira has also published several briefing papers and reports for EU institutions and think-tanks (orcid: 0000-0002-5643-0398).

\section{Abstract}

The armed conflict that has erupted in Ukraine in 2014 has been affecting the way the states involved interact and how they seek to implement certain narratives in a new regional political context. While Russia has taken a more assertive stance in its neighbourhood through a narrative that seeks to contradict Western values promoted by the European Union (EU), the latter has shown some difficulty in presenting a coherent narrative in the face of developments over the past five years.

In this sense, this article proposes to analyse the EU-Russia interaction, using as a case study the incident involving the crash of the Malaysia Airlines civil aircraft MH17. The analytical perspective combines elements of Role Theory - which here focuses on the interaction of states on the basis of certain expectations regarding their internal (national) and external (regional/international) roles - and Strategic Narratives. The differences between issue narratives (including regarding the Bellingcat Investigation Team narrative), system narratives and identity narratives are explored. The argument presented here is that the externalization of the EU issue narrative has emerged in two distinct ways - one more moderate in its official stance as an institution; another more assertive from the point of view of the work done by the East Stratcom Task Force (EATF). This ends up creating some dissonance in the way the European Union designs its narrative, and misalignment with the EU's narrative identity as a role state.

\section{Keywords}

MH-17, Role Theory; Strategic Narratives; Ukraine; European Union; Russia

\section{How to cite this article}

Ramos, Paulo; Vieira, Alena (2019). "European Union, Russia and the MH17 case: strategic narratives' analysis (2014-2019)". JANUS. NET e-journal of International Relations, Vol. 10, N.0 2, November 2019-April 2020. Consulted [online] on the date of the last visit, https://doi.org/10.26619/1647-7251.10.2.4 


\title{
EUROPEAN UNION, RUSSIA AND THE MH17 CASE: STRATEGIC NARRATIVES' ANALYSIS (2014-2019) ${ }^{12}$
}

\author{
Paulo Ramos
}

Alena Vieira

\section{Introduction}

The armed conflict in Ukraine in the Donbass region gained renewed momentum with the crash of the Malaysia Airlines plane on the route between Amsterdam and Kuala Lumpur on 17 July 2014 as it flew over the conflict zone in Eastern Ukraine. The death of almost 300 people, the vast majority European, has led EU countries to take a more assertive joint stance in seeking a resolution of the armed conflict in that region. The EU's stance stood out for greater unity, paving the way for broader sanctions against Russia, targeting key sectors of the Russian economy, including the financial, arms and energy sectors. However, the Minsk Protocol signed in September 2014 under the auspices of the OSCE failed to achieve the ceasefire proposed in the document. The same happened with Minsk II, signed by the Ukraine, Russia, France and Germany in February 2015, which unsuccessfully sought to resolve the shortcomings of the first agreement.

Petro Poroshenko, who in 2014 became the new President of Ukraine, since the beginning was determined to regain institutional ties with the EU, while Russia has sought to implement new ways of destabilizing the country and fostering its own narrative about the events in Ukraine. His successor, Volodymyr Zelensky, elected in 2019, is in the same position and has the same aspirations. Thus, having at its doorstep a conflict which, according to the UN, has already led to the deaths of 13,000 people, of whom over 3,000 civilians (Office of the United Nations High Commissioner for Human Rights, 2019) means that the EU's foreign policy has come under heavy media pressure in recent years, which further increases its responsibility in this process.

Through the analysis of various secondary and primary sources, this paper aims to analyse the evolution of the narratives of Russia and the EU in relation to the fall of the MH17, which serves as the main case study in this context.

The translation of this article was co-funded by Instituto Camões in the framework of the 1st International Conference on Conflict Resolution and Peace Studies. Text translated by Carolina Peralta.

2 Special issue of articles presented at the 1st International Conference on Conflict Resolution and Peace Studies that took place at UAL on the $29^{\text {th }}$ and $30^{\text {th }}$ of November 2018. 


\section{Theoretical framework}

The theoretical framework of this article will be based on the concept of Role Theory. Developed in the field of sociology and psychology, this theoretical framework has been adapted to international relations since the 1970s (Harnisch, 2011, p.7; see Walker 1987). The roles played by certain actors are defined as "social positions" influenced by internal and external expectations regarding their purpose (Thies, 2010b, p. 6336; Andrews, 1975, p. 529; quoted in Harnisch, 2011, p.8).

According to Sebastian Harnisch, role expectations and role conceptions arise internally (ego) and externally (alter), and can be challenged, as the role of a particular actor can collide with that of another. According to Stephan Klose (2018, p. 6), for example, "the ability of an international actor to fulfil his or her representative aspirations in society depends as much on his/her creativity and resources as on the social expectations of others".

In this sense, post-Soviet states have different perceptions of the EU's role in the region, and only a few see the institution as a normative power (Nitoiu, 2018, p. 704). This brief explanation is relevant in the context of this article, as the perception and expectations of the EU's role as an international actor are not uniform, within the EU or outside the institution - notably in Russia, with whom it often collides, as the conflict in Ukraine exemplifies (Ademmer et al., 2016; Chaban and Holland, 2014; Delcour and Wolczuk, 2018; Lucarelli, 2014).

Dirk Nabers (2011, p. 82) presents two distinct ways in which the roles played by different actors relate to their identities. On the one hand, the role of a particular actor represents the limit of his actions, which in turn defines his identity. On the other hand, the actor's representation can also be influenced by his identity, and the former can serve as a reference or framework for the latter (Nabers, 2011, p. 83). This is important in the context of the EU, particularly in the case of the conflict in Ukraine, due to what several authors identify as an imbalance between what is perceived as "European identity" and what is done in foreign policy matters.

In addition to the support provided by Role Theory as a theoretical approach, this paper will also use Strategic Narratives, a concept developed by Alister Miskimmon, Ben O'Loughlin and Laura Roselle (2013). This choice is because it allows us to better understand how communication (political and not only) affects relations between states, something that may also help to understand whether this narrative fits in with the identity and role of the EU.

The armed conflict in Ukraine is particularly highlighted by the confrontation of interests, discourses and identities between the actors involved, whether they stand closer to the EU narrative or to the Russian narrative. For this reason, it is crucial to understand how these dynamics evolve and affect the actors involved, especially at a time when Russia seeks to assert itself as a true global actor, and in a context where the EU suffers the consequences of migration-related problems, Brexit or the US administration led by Donald Trump.

\section{EU - Ukraine - Russia - An Imperfect Triangle}


The armed conflict in Ukraine has attracted academic attention in recent years as it has become a stage for combat, not only in military terms but above all in political communication. However, empirical applications of the Strategic Narratives concept in this context are not often found. Moreover, the work that has been developed focuses mainly on the impact of the Russian narrative, as exemplified by the contributions of Joanna Szostek $(2017 ; 2018)$ or Irina Khaldarova (2016). It is, therefore, important to understand how this dynamic has been built on the EU side, and what influence it has had on consolidating the role of the organization as an international actor.

Some authors defend that the EU behaved like any other actor under the circumstances, and noted that the reaction was quick on several levels (Karolewski and Cross, 2017, p.138). Michal Natorski and Karolina Pomorska (2017, p.66) also agree with this idea, saying that the armed conflict in Ukraine has even led to increased confidence among EU members in the face of growing discomfort in relations with Russia. The cleavage between the EU and Russia is, moreover, one of the most important aspects of this conflict because of the consequences it has not only for Ukraine but also for the first two. Regarding this difference, Svante Cornell argues as follows:

\begin{abstract}
"(...) the Russian sphere of influence is incompatible not only with the form of European integration envisaged by the EaP, but at a more fundamental level with the type of countries that the EU's instruments would help to create. Where European leaders want a stable neighbourhood, Russia seeks an unstable one; where Europe seeks to develop accountability, Russia undermines it. Thus, the competition between Russia and Europe is not only geopolitical; it is fundamentally ideological." (Cornell, 2014, p.119)
\end{abstract}

Allister Miskimmon (2017, p.164) states that the incongruity of the EU narrative in relation to Ukraine has affected the institution's international credibility and hampered the process of affirmation as an international actor in foreign policy. Although the argument does not refer directly to the MH17 issue, it demonstrates the EU's difficulty in creating a narrative that can be receptive not only to the Ukrainian community, but also within the institution; Ukraine thus represents "a test for its identity narrative as a regional peacemaker and defender of universal values" (Miskimmon (2017, p.161).

The idea that the EU has played a limited role in the face of the Ukrainian conflict is supported by other authors. Taras Kuzio, for example, presents three factors to support this argument: the inability to exert an assertive influence on internal reforms in Ukraine, given the lack of a prospect of integration of the country into the EU; the difficulty in understanding the motivations of Ukrainian elites; and the difficulty in understanding Russia's foreign policy dynamics in thinking that enlargement to eastern countries would have no repercussions (Kuzio, 2017, pp.116-117).

The difficulties experienced in dealing with the Ukraine stem in part from a relationship with various ups and downs over the last two decades. This link between the two parties is described as an "ambiguous partnership, founded on a complex legal and institutional design" (Ferreira-Pereira and Vieira, 2014, p.12). Apart from this institutional difficulty, Ukraine's rapprochement with the EU has also been affected by internal problems such 
as corruption or lack of stable democratic institutions. Indeed, "the willingness of the elites to exploit energy dependence for their own benefit" is seen as one of the main reasons for the high Ukrainian dependency vis-à-vis Russia (Dragneva and Wolczuk, 2016, p.694). This makes "the obstacles that Ukraine faces on its 'path to Europe' formidable" (Wolczuk, 2017, p.287). The same author, in another article, highlights the irony that, "after decades of marginalization, Ukraine has become crucial to debates about the future of Europe" (Wolczuk, 2016, p.70).

This somewhat tumultuous relationship is exacerbated, as it turns out, by Russia's growing detachment from the EU, and vice versa. Relations within this triangle, at least until the beginning of the conflict, are described by Vsevolod Samokhvalov (2015, p.1372) as "a more or less homogeneous complex of zero-sum dynamics". The author lists four key arguments in the development of this process, which should be noted carefully: firstly, each of the actors (EU and Russia) seeks to introduce into Ukraine political practices in line with their own values and interests; secondly, at economic level, each actor has sought to open the Ukrainian market to its own markets in order to create a transnational dynamic; thirdly, both sides have sought to lure Ukraine into their security projects in the region, a scenario in which NATO also appears as a central actor; finally, each side has attempted to introduce an ideology and perception of history closer to its interests (Samokhvalov, 2015, pp.1372-1373).

All this leads to the belief that the EU has indeed had several difficulties in assuming a coherent role vis-à-vis Russia and Ukraine. Moreover, the role it plays is not always viewed positively (by other actors). According to Bengtsson and Elgstrom (2011, p.129), this is a consequence of inconsistent performance and contradictory elements in the development - and the current result - of European integration.

\section{Strategic Narratives in the Context of Armed Conflict in Ukraine}

Given the scenario described above, it is important to explore more carefully the Strategic Narratives concept. According to Miskimmon, O'Loughlin and Roselle, they are "representations of a sequence of events and identities, a communicative tool through which political actors - usually elites - try to attribute a particular meaning to the past, present and future in order achieve political goals" (Miskimmon et al., 2013, p.5).

The focus on these narratives as vehicles for the transmission of ideas or identities is important because it allows "to connect the space between the concepts of hard and soft power" (Roselle et al., 2014, p.75), because the narrative of a particular actor may, for example, include the use of military resources, so the study of communication and narratives makes it possible to bridge the gap between these two concepts and to realize that boundaries are not always easily discernible.

An important aspect of Strategic Narratives, especially in the context of the work conducted here, is its division into three distinct forms: issue narratives; identity narratives; and system narratives (Miskimmon, 2017, p. 155). In the case of the first, the author explains that they refer to how a particular narrative suits a policy, particular action or event. Identity narratives are related to the identity that a given actor attributes to himself, and that ends up influencing his narrative and how to act in the international arena. Finally, system narratives refer to how these same actors view the modern 
international system, which in turn influences the way narratives are created and projected.

Some authors use the Strategic Narratives concept as part of an analysis of the spread of fake news during the armed conflict in Ukraine (Khaldarova and Pantti, 2016). The authors conclude that fabricated news and reports are part of a pre-established strategy to "elicit an affection response from the public" (Khaldarova and Pantti, 2016, p.899). This means that strategic narratives can, in certain contexts, take on a destabilizing role, as has been seen in relation to Russia's position in the conflict with Ukraine.

One of the main catalysts of this informative "anarchy" characteristic of modern conflicts was the emergence of new communicative tools, namely social media. One of the great innovations of this technology was that it "provides users with the ability to search for information and share their own content within their own networks" (Zeitzoff, 2017, p.1972). This ultimately creates a more chaotic environment where information can be reproduced and shared by anyone with access to these tools, thus increasing the possibility of fake news spreading - extremely common in the context of the $\mathrm{MH} 17$ incident, as we will see later. In the case of the conflict between Russia and Ukraine, this can be seen as a case where the Internet has increased the power of the actors involved to produce disinformation (Mejias and Vokuev, 2017, p.1027).

This new communicative environment is often described as the post-truth regime, that is, a world in which facts are less important in shaping public opinion than appeals to personal emotions and beliefs. This aspect becomes increasingly important considering that the identity of populations is a central factor in the perception of certain narratives. In the case of Ukraine, for example, Joanna Szostek (2018, p.129) states that "it should not be surprising that people negotiate the meaning of news with reference to their values and experiences". This idea is present in another article by the same author:

\footnotetext{
"A state may spend any amount of money on disseminating messages about itself and the world, but the results will ultimately still hinge on factors that are largely beyond its control - including the attributes of (multiple, diverse) receiving audiences and the discursive context." (Szostek, 2017: p.380).
}

If narratives are produced by actors in order to achieve certain goals, those same narratives are susceptible to manipulation by the actors involved. In this sense, it is important to frame the concept of disinformation. This can be understood as "intentional lies spread as simulated news or documentary formats to achieve political ends" (Bennett and Livingston, 2018, p.124). The ease with which this type of malicious information circulates among the various media makes it increasingly difficult to distinguish the true information from the one that merely intends to lie or mislead.

Some authors place the responsibility of this process in the strengthening of social networks as a vehicle of communication (Hannan, 2018). This makes it critical to analyse the evolution of this procedure on social networks, where the spread of fake news is considerably easier and more effective. 
In the case of Ukraine and the conflict that started in 2014, one of the existing arguments is that "the use of social media has weakened the power of civil society by allowing the rampant diffusion of disinformation" (Mejias and Vokuev, 2017, p. .1028). Associated with what is considered to be a "breach of trust in democratic press and political institutions" (Bennett and Livingston, 2018, p.127), the sheer amount of information sources in today's communication landscape makes disinformation an increasingly viable tool. Let us look at the words of Bennett and Livingston for an idea of this context:

\begin{abstract}
"Compared to the mass media era, the current age displays a kaleidoscopic mediascape of television networks, newspapers and magazines (both online and print), YouTube, WikiLeak, and LiveLeak content, Astroturf think tanks, radical websites spreading disinformation using journalistic formats, Twitter and Facebook among other social media, troll factories, bots, and 4chan discussion threads, among others." (Bennett e Livingston, 2018, p.129)
\end{abstract}

This helps to create a more chaotic information environment, a kind of "far-west communication" (Hannan, 2018, p.11). In turn, this factor increases the possibility of "information wars", as has been the case in Ukraine, where different positions seek to dilute the importance of the adversary's narrative. In one of her studies of the Ukrainian population, Joanna Szostek demonstrates how most people who participated in the study looked at the general media with a high level of distrust (Szostek, 2018, p.124).

This type of hybrid combat methods (using not only traditional military means but also information warfare systems) has been a major concern for the EU, especially given Russia's recent external action (Wagnsson and Hellman, 2018). These authors propose a normative stance that favours support to secondary actors who can challenge attitudes they identify as incorrect, without seeking to ridicule "the other" (Wagnsson and Hellman, 2018, p.12). This difficulty within the EU to find a proper stance towards what is generally understood as Russia's escalation in hybrid warfare demonstrates the importance of using the concept of Strategic Narratives. By understanding how this process is assembled and propagated, it will be easier in the future to find ways to deal with it.

On the other hand, the literature on this subject has focused, as previously mentioned, on the impact of Russian narratives during the armed conflict in Ukraine (Khaldarova and Pantii, 2016; Mejias and Vokuev, 2017; Szostek, 2017; Szostek, 2018). One of the shortcomings this article intends to fill is precisely to explain the EU's role in this process, and to understand how the European narrative has evolved over the last few years.

\title{
MH-17 and the Clash of Narratives
}

The crash of the MH17 plane in July 2014 was a pivotal moment with regard to the evolution of the narratives of the actors involved regarding the conflict in Ukraine. On 
the one hand, the EU has had the opportunity to strengthen its role as a relevant player on the ground, as two of its members (the Netherlands and Belgium) have been directly affected, and have been involved in the Joint Investigation Team (JIT) ${ }^{3}$, the team responsible for analysing the MH17 case. On the other hand, Russia has sought to use the incident as evidence that the West continues to push the country away from the centre of decisions, in particular because of its refusal to participate in the JIT (see Table 1). However, Russia's stance was not oriented towards cooperation; instead, a context has been created in which the JIT has been constantly confronted with new versions of the events leading up to the MH17 tragedy. In this section, we look at some important turning points in the development of the MH17-related process.

On 18 July 2014, a day after the MH17 crash, Ukrainian authorities revealed several tapes of conversations between Ukrainian separatists and Russian military officials about the crash (BBC, 2014). Although it was not possible to confirm their veracity, the suspicions raised from the first hour centred Russia's participation in the crash of the aircraft. This prompted a rapid reaction from the Russian government, which immediately took an accusatory stance on Ukraine's role in the case. In an official statement made on the same day, the Russian Ministry of Defence asserted that Russian air defence systems did not operate in that area on the day of the crash, implying that there would be Ukrainian forces with access to equal air defence units in the region, the same as those used to shoot down the plane, the BUK-TELAR (Russian Ministry of Defence, 2014).

On 21 July, the same ministry held a press conference where it directly accused Ukraine of the disaster, notably through a model Su-25 Ukrainian fighter plane, allegedly sighted near the MH17 before the crash. According to the Bellingcat group, all hypotheses raised by Moscow "have been refuted by multiple sources, sometimes even by the evidence provided by the Russian government itself" (Toler, 2018). For several months after the disaster, the Russian narrative of events alternated mainly between these two versions: on the one hand, that the plane had been shot down by a Ukrainian army-controlled BUK system; On the other hand, the theory that it was a Ukrainian fighter plane to cause the fall of the $\mathrm{MH} 17$.

As early as June 2015, an analysis by Russian state-owned armament company AlmazAntey claimed that the 9M38M1 missile, used to shoot down the MH17, had not been used by Russian forces since 1999 (Russia Today, 2015). This information came in line with the theory that the missile was operated by Ukrainian forces without Russian military personnel being involved in the process. Once again, the Bellingcat research group contested this information, bringing together a set of images showing how the Russian military continued to use the same type of missile (Higgins, 2015). In October of the same year, the Dutch Safety Board's (DSB) ${ }^{4}$ final report concluded that the MH17 was indeed shot down by a Russian-made BUK system, even though it had no definitive conclusions as to who was responsible for shooting it (Dutch Safety Board, 2015). These results, though not definitive, again put the Russian government under fire. Once again, the Moscow narrative was one of denial, trying to convey the message that the West was trying to incriminate Russia without sufficient evidence (see Table 1).

3 The Joint Investigation Team was created after the fall of the MH17 in August 2014 to lead the criminal investigation of the case. The group is made up of police and judicial forces from the Netherlands, Ukraine, Belgium, Malaysia and Australia.

4 The Dutch Safety Board was invited to participate in the MH17 criminal investigation by the National Bureau of Air Accidents Investigation of Ukraine. 
In this context, the years following the incident were marked by a narrative battle in which the results raised by the DSB or JIT were quickly refuted by Russian officials, who sought to feed various theories about the plane crash, particularly the two referred to above. In September 2016, for example, the Russian Ministry of Defence presented radar images showing the alleged presence of Ukrainian air defence systems in the region where the $\mathrm{MH} 17$ had crashed, but without reference to the presence of Ukrainian military aircraft near the $\mathrm{MH} 17$, in contradiction to what had been said two years earlier at the press conference on 21 July 2014 (Higgins, 2016).

It appears, therefore, that Russia's attitude throughout the process has varied, demonstrating a serious inconsistency in its issue narrative dimension - notably as regards its concern with the issue of the BUK missile that shot down the MH17 and the details that involved its production process and transportation to Ukrainian territory. Moreover, in the identity narrative dimension, we can frame the Russian stance, in the context of Role Theory, as an ego state - especially in the context of its contesting stance on the work of the JIT, the attribution of responsibility to Ukraine, and the criticism of the EU as well as of the West for unconditional support for Ukraine (Telegraph 2014, see Table 1).

Although the case has lost some media attention since then, the May 2018 JIT report has once again focused attention on Russia's alleged role. Let us look at one of the main conclusions:

\footnotetext{
"Today, the JIT has concluded that the BUK-TELAR which was used to shoot down flight MH17 originated from the 53rd Anti-Aircraft Missile Brigade of the Russian armed forces. This observation raises questions, such as the question whether the Brigade itself was actively involved in the downing of flight MH17 on 17 July 2014. An important question, which the JIT is still investigating." (Joint Investigation Team, 2018)
}

According to the argument put forward, the Russian military would have been directly involved in transporting the system used to shoot down the MH17, a narrative corroborated by the Bellingcat team. The Russian narrative, on the other hand, remains to be one of denial of any involvement in the case, reinforcing (recently) the accusatory stance towards Ukraine. In September 2018, the Russian army announced that the missile used to shoot down $\mathrm{MH} 17$ belonged to the Ukrainian military, having left Russian territory in 1986 (Vasilyeva, 2018).

On 19 June 2019, the JIT announced that criminal proceedings will be initiated in the Netherlands against four persons responsible for the MH17 flight tragedy.

\section{The East Stratcom Task Force and the EU's Response}

The traditional EU's difficulty to act with one voice towards Ukraine has increased in recent years by the growing campaigns of discrediting and disinformation promoted largely in the context of conflict by Russian-influenced media or the Kremlin itself. This is particularly relevant given the EU's inability to prevent its members from sometimes 
having different or even contradictory positions (Karolewski and Cross, 2017, p. 148). Nevertheless, the fall of the MH17 initially boosted the EU's stance towards Russia, particularly through the tightening of sanctions imposed on Moscow and the assertiveness of some previously reluctant actors to harass Russia, with particular emphasis on the case of Germany. This change, brought about by the deaths of European citizens, has allowed the EU to attribute itself its own narrative as a prominent actor in the region, whose role is central to the resolution of the conflict, assuming its position as role state in the face of Russian involvement. The EU's strategic narrative stands out for its recognition that Russia is involved in the armed conflict in Ukraine, and calls on Russia to assume its responsibility for the MH17 tragedy (e.g. High Representative, 2018, 2019).

However, particularly at the outset, the EU sought to move away from the 'narrative war' on the course of events leading to the fall of the $\mathrm{MH} 17$, without following the changes in the Russian narrative, or to highlight the serious inconsistency of this narrative in its official discourse. Eventually, this made the Russian strategic narrative maintain its projection, which was further reinforced by the surprising position of Mahathir Mohamad, Prime Minister of Malaysia, who in June 2019, contrary to the previous government's position, challenged the JIT conclusions by stating that the latter had no evidence of Russian involvement in the tragedy.

The EU's stance - which focused on supporting the work of the EIC/JIT, considered 'essential' and conducted 'with independence, professionalism and impartiality' (High Representative, 2018) - went no further than this, ultimately weakening the issue narrative dimension of the EU'S strategic narrative, creating a misalignment with its narrative identity of an actor invested in the promotion and defence of human rights, values, and able to contribute to the resolution of an armed conflict, in line with the action of a role state (see Table 1 ).

The main way the EU found to counter Russian disinformation campaigns was the establishment in 2015 of the East Stratcom Task Force (ESTF), a team to monitor and document disinformation narratives that are somehow linked to Russia or related media groups operating in the Eastern European region. In its conclusions of March 2015, the European Council reiterated the "need to address continuing Russian disinformation campaigns" (European Council, 2015), which led to the writing of an Action Plan presented in June of that year. The importance the EU attaches to the ESTF is appreciated by its assessment of the systematization of 4500 cases of Russian disinformation by the Council in 2018 and the tripling of the ESTF budget in 2019 compared to that in 2018 (EEAS 2018). However, the ESTF position "cannot be considered the official position of the EU" (EEAS 2018).

Through a weekly publication entitled Disinformation Review and its EUvsDisinfo website, the ESTF seeks to analyse fake or biased news in favour of the Kremlin's official position. Unlike the EU, the ESTF takes a much more critical stance on Russia's role in the armed conflict in Ukraine. In the case of the MH17, the work conducted resulted in the publication of several articles that generally point to Russia as responsible for covering up the true cause and those responsible for the crash of the plane, with 'nine waves' of Russian disinformation directed at the $\mathrm{MH} 17$ case to be listed in one of the analysed examples (EUvsDisinfo 2017).

In another article on the subject, the team argues that "the Russian authorities have been conducting, together with the media, a disinformation campaign that they directly 
and indirectly control in order to cover up the truth about who shot down the MH17 flight of the Malaysian Airlines in Eastern Ukraine" (EUvsDisinfo, 2018). A more recent article presents a chronological analysis of what is defined as "five years of pro-Kremlin disinformation campaigns" (EuvsDisinfo2019). This shows that the ESTF sees Russia not only as an "enemy" of MH17 research, but also as an obstacle to the EU's own values.

If we compare this position with that of a certain official withdrawal from the EU regarding these disinformation campaigns, we find that there is a dissonance in the EU's strategic narrative, with a more thoughtful position and seeking to maintain an open line of dialogue with Russia; and another more assertive, which clearly identifies Russia as an antagonistic actor - the position of the ESTF. The latter better aligns the EU issue narrative and identity narrative as a normative actor in line with a role state, but is not accepted as an official EU strategic narrative.

\section{Conclusions}

The armed conflict that started in Ukraine in 2014 has proved to be a difficult obstacle for the EU in terms of foreign policy and international projection. The $\mathrm{MH} 17$ flight tragedy serves as the clearest example of this conflict as a combat stage, not only in military terms, but above all in political communication.

In the case of Russia, the response to the incident has ranged from a focus on issue narrative - notably as regards its concern with the issue of the BUK missile that shot down the $\mathrm{MH} 17$ and the details that involved its production process and transport to Ukrainian territory; and on a narrative identity that we can frame, in the context of the Role Theory, as an ego state - especially in the context of its stance on the JIT's work. The narrative dimensions presented turn out to be inconsistent and misaligned, but ultimately create a serious challenge for the projection of the EU's own narrative, which initially sought to move away from this war of narratives.

Table 1. Russian and EU strategic narratives regarding the MH 17: identity, system, issue

\begin{tabular}{|c|c|c|c|}
\hline & Identity & System & Issue (MH17) \\
\hline Russia & $\begin{array}{l}\text { - Narrative of an ego state } \\
\text { - Western attempts to } \\
\text { represent Russia as 'guilty' } \\
\text { and 'enemy' - exclusion of } \\
\text { Russia by the West/EU and } \\
\text { non-acceptance of Russia } \\
\text { as a Global Actor; }\end{array}$ & $\begin{array}{l}\text { - Confrontation between } \\
\text { Russia and the West in } \\
\text { Europe } \\
\text { - EU / West should } \\
\text { accept Russia as ego } \\
\text { state for the sake of } \\
\text { regional stability }\end{array}$ & $\begin{array}{l}\text { - Responsibility for the } \\
\text { tragedy: Ukrainian; } \\
\text { - Criticism of unconditional } \\
\text { Western support for Ukraine, } \\
\text { both regarding MH17 and } \\
\text { armed conflict }\end{array}$ \\
\hline EU & $\begin{array}{l}\text { - Narrative of a role state } \\
\text { - Actor aspiring to find } \\
\text { solution to regional } \\
\text { conflicts } \\
\text { - Governance based on the } \\
\text { principles of democracy and } \\
\text { human rights The power of } \\
\text { the EU example (despite } \\
\text { Brexit) }\end{array}$ & $\begin{array}{l}\text { - Principles of } \\
\text { Democracy and } \\
\text { Human Rights } \\
\text { - Principled pragmatism }\end{array}$ & $\begin{array}{l}\text { - Responsibility for the } \\
\text { tragedy: Russian, must be } \\
\text { assumed by Russia } \\
\text { - Russia's involvement in the } \\
\text { armed conflict in Ukraine: } \\
\text { Russia as a Problem and not } \\
\text { as a Strategic Partner } \\
\text { *** - STRATCOM: Russia as } \\
\text { responsible actor for } \\
\text { purposeful disinformation } \\
\text { and challenging EU values }\end{array}$ \\
\hline
\end{tabular}

Source: Table prepared by the authors, based on Miskimmon's contribution (2017). 
Following the analysis presented here, we find that this withdrawal made it difficult to project a more assertive narrative, officially, a kind of "outsourcing" of the response to the Member States and the JIT taking place. The clearest answer comes as a result of the work of the ESTF and the "EU v. Disinfo", although it is rarely incorporated into the EU's position as an institution. The dissonance that results from this EU position ultimately weakens the issue narrative dimension of its strategic narrative, further creating incongruity with its narrative identity as an actor invested in the promotion and defence of human rights, values, and able to contribute to the peace in the region. We can conclude that the EU, while seeking to maintain its narrative identity as a role state in the region, has had difficulty fighting Russia's constant disinformation campaigns in the context of the fall of the MH17.

The aspiration to maintain its narrative identity did not result in the institution projecting a consistent and strong enough narrative, but it served as a kind of "testing ground" for the projection of new disinformation campaigns.

\section{References}

Ademmer, E., Delcour, L. and Wolczuk, K. (2016) 'Beyond geopolitics: exploring the impact of the EU and Russia in the 'contested neighborhood" Eurasian Geography and Economics 57(1): pp. 1-18.

High Representative of the EU (2018). Statement by High Representative Federica Mogherini on behalf of the EU on the third anniversary of the shooting of the Malaysian Airlines flight MH17. Available at: https://www.consilium.europa.eu/pt/press/pressreleases/2018/07/17/declaration-by-the-high-representative-on-behalf-of-theeuropean-union-on-the-occasion-of-the-fourth-anniversary-of-the-downing-ofmalaysian-airlines-flight-mh17/ (retrieved on: 21 August 2019).

BBC (2014) 'MH17 crash: Ukraine releases alleged intercepts', British Broadcasting Corporation, 18 July. Available at: https://www.bbc.com/news/world-asia-28362872 (retrieved on: 12 October 2018).

Bengtsson, R. and Elgstrom, O. (2011) 'Reconsidering the European Union's roles in international relations' in Harnisch, S., Frank, C. e Maull, $\mathrm{H}$. (eds) Role Theory in International Relations: Approaches and Analyses. Oxford: Routledge, pp. 113-129.

Bennett, W. L. and Livingston, S. (2018) 'The disinformation order: Disruptive communication and the decline of democratic institutions' European Journal of Communication 33(2): pp. 122-139.

Chaban, N. and Holland, M. (2014) 'Introduction: The Evolution of EU Perceptions: From Single Studies to Systematic Research' in Chaban, N. and Holland, M. (eds) Communicating Europe in Times of Crisis: External Perceptions of the European Union. Palgrave Macmillan, UK, pp. 1-23.

Cornell, S. E. (2014) 'Underestimating yourself: the EU and the political realities of the eastern neighbourhood' European View 13: pp. 115-123. 
Delcour, L. and Wolczuk, K. (2018) 'Well-Meaning but Ineffective? Perceptions of the EU's Role as a Security Actor in the South Caucasus' European Foreign Affairs Review 23(1): pp. 41-60.

Dragneva, R. and Wolczuk, K. (2016) 'Between Independence and Integration: Ukraine's Relations with Russia' Europe-Asia Studies 68(4): pp. 678-698.

Dutch Safety Board (2015) 'Crash of Malaysia Airlines flight MH17', October 2015, Haia. Available at: https://www.onderzoeksraad.nl/en/page/3546/crash-mh17-17-july-2014 (retrieved on: 14 October 2018).

Office of the United Nations High Commissioner for Human Rights (2019). Report on the human rights situation in Ukraine 16 November 2018 to 15 February 2019. Available at: https://www.ohchr.org/Documents/Countries/

UA/ReportUkraine16Nov2018-15Feb2019.pdf (retrieved on: 21 July 2019).

EUvsDisinfo (2017). Time for the ninth MH17 disinformation round. Available at: https://euvsdisinfo.eu/time-for-the-ninth-mh17-disinformation-round/( retrieved on: 14 August 2019).

EuvsDisinfo (2018). MH17: Time is running out for disinformation. Available at: https://euvsdisinfo.eu/mh17-time-is-running-out-for-disinformation/ (retrieved on: 21 July 2019).

EUvsDisinfo (2019). Tracing Five Years of Pro-Kremlin Disinformation about MH17. Available at: https://euvsdisinfo.eu/tracing-five-years-of-pro-kremlin-disinformationabout-mh17/ (retrieved on: 21 August 2019).

Ferreira-Pereira, Laura C., and Alena Vieira (2015) 'Ukraine in the European Union's Partnership Policy: A Case of Institutionalized Ambiguity' European Politics and Society 16(2): pp. 143-158.

Hannan, J. (2018) 'Trolling ourselves to death? Social media and post-truth politics' European Journal of Communication 33(2): pp. 1-13.

Harnisch, S. (2011) 'Role Theory: Operationalization of key concepts' in Harnisch, S., Frank, C. and Maull, H. (eds) Role Theory in International Relations: Approaches and Analyses. Oxford: Routledge, pp. 7-15.

Higgins, E. (2015) 'Evidence the Russian Military Supplied the Type of Missile Used to Shoot Down MH17', Bellingcat, 3 June. Available at: https://www.bellingcat.com/news/uk-and-europe/2015/06/03/evidence-the-russianmilitary-supplied-the-type-of-missile-used-to-shoot-down-mh17/comment-page-1/ (retrieved on: 13 October 2018).

Higgins, E. (2016) 'The Russian Defense Ministry Presents Evidence They Faked Their Previous MH17 Evidence', Bellingcat, 26 September. Available at: https://www.bellingcat.com/news/uk-and-europe/2016/09/26/russian-defenceministry-presents-evidence-faked-previous-mh17-evidence/ (retrieved on: 13 October 2018)

Joint Investigation Team (2018) 'JIT MH17 Press Meeting', 24 May, Utrecht. Available at: https://www.om.nl/onderwerpen/mh17-vliegramp/

persbijeenkomst-24/narrative-conference/ (retrieved on: 14 October 2018). 
Karolewski, I. P.and Cross, M. K. (2017) 'The EU's Power in the Russia-Ukraine Crisis: Enabled or Constrained?' JCMS 55(1): pp. 137-152.

Khaldarova, I. (2016) 'Strategic Narratives of the Ukraine Conflict Projected for Domestic and International Audiences by Russian TV Channels" in Pantti, M. (Ed.). Media and the Ukraine Crisis: Hybrid Practices and Narratives of Conflict. New York: Peter Lang, 124138.

Khaldarova, I. and Pantti, M. (2016) 'Fake News: The narrative battle over the Ukrainian conflict' Journalism Practice 10(7): pp. 981-901.

Klose, S. (2018) 'The emergence and evolution of an external actor's regional role: An interactionist role theory perspective' Cooperation and Conflict: pp. 1-16.

Kuzio, T. (2017) 'Ukraine between a Constrained EU and Assertive Russia' JCMS 55(1): pp. 103-120.

Lucarelli, S. (2014) 'The EU's Leadership in Global Governance: Perceptions from the others' in Chaban, N. e Holland, M. (eds) Communicating Europe in Times of Crisis: External Perceptions of the European Union. Palgrave Macmillan, UK, pp. 45-64.

Mejias, U. A. and Vokuev, N. E. (2017) 'Disinformation and the media: the case of Russia and Ukraine' Media, Culture \& Society 39(7): pp. 1027-1043.

Russian Ministry of Defence (2014) 'Official statement from the Russian Defence Ministry in connection with Boeing 777 crash', 18 July, Moscow. Available at: https://www.globalresearch.ca/mh-17-crash-in-ukraine-official-statement-fromrussian-defense-ministry/5392000 (retrieved on: 12 October 2018).

Miskimmon, A., O'Loughlin, B. and Roselle, L. (2013) Strategic Narratives: Communication Power and the New World Order. New York, Routledge.

Miskimmon, A. (2017) 'Strategic narratives of EU foreign policy and the European Neighbourhood Policy' in Schumacher, T., Marchetti, A. and Demmelhuber, T. (eds) The Routledge Handbook on the European Neighbourhood Policy. Oxford: Routledge, and New York: Routledge, pp. 153-166.

Nabers, D. (2011) 'Identity and role change in international politics' in Chaban, N. and Holland, M. (eds) Communicating Europe in Times of Crisis: External Perceptions of the European Union. Palgrave Macmillan, UK, pp. 74-92.

Natorski, M. and Pomorska, K. (2017) 'Trust and Decision-making in Times of Crisis: The EU's Response to the Events in Ukraine' JCMS 55(1): pp. 54-70.

Nitoiu, C. (2018) 'The European Union's 'Ideal Self' in the Post-Soviet Space' Europe-Asia Studies 70(5): pp. 692-710.

Roselle, L., Miskimmon, A. and O'Loughlin, B. (2014) 'Strategic Narrative: A New Means to Understand Soft Power' Media, War \& Conflict 7 (1): pp. 70-84.

Samokhvalov, V. (2015) 'Ukraine between Russia and the European Union: Triangle Revisited' Europe-Asia Studies 67(9): pp. 1371-1393.

Swimelar, S. (2017) 'Deploying images of enemy bodies: US image warfare and strategic narratives' Media, War \& Conflict 11(2): pp. 179-203. 
Szostek, J. (2017) 'The Power and Limits of Russia's Strategic Narrative in Ukraine: The Role of Linkage' Perspectives on Politics 15(2): pp. 379-395.

Szostek, J. (2018) 'Nothing is True? The credibility of News and Conflicting Narratives during 'Information War' in Ukraine' The International Journal of Press/Politics 23(1): pp. 116-135.

Telegraph (2014) MH17 plane crash: Russia's UN ambassador accuses the world of taking Ukraine's side, Available at: https://www.telegraph.co.uk/ news/worldnews/europe/russia/10977407/MH17-plane-crash-Russias-UN-ambassadoraccuses-the-world-of-taking-Ukraines-side.htm (retrieved on: 21 August 2018).

Russia Today (2015) 'MH17 likely downed by old BUK-M1 missile system not used by Russia - manufacturer', Russia Today, 3 June. Available at: https://www.rt.com/news/264421-buk-missile-manufacturer-investigation/ (retrieved on: 13 October 2018).

Toler, A. (2018) 'The Kremlin's Shifting, Self-Contradicting Narratives on MH17', Bellingcat, 5 January. Available at: https://www.bellingcat.com/news/uk-andeurope/2018/01/05/kremlins-shifting-self-contradicting-narratives-mh17/ (retrieved on: 13 October 2018).

Wagnsson, C. and Hellman, M. (2018) 'Normative Power Europe Caving In 'EU under Pressure of Russian Information Warfare' JCMS 56(5): pp. 1161-1177.

Walker, S. G. "Role Theory and the Origins of Foreign Policy." In New Directions in the Study of Foreign Policy. Edited by Charles F. Hermann, Charles W. Kegley, and James N. Rosenau, 269-284. London: Harper Collins, 1987.

Wolczuk, K. (2016). 'Ukraine and Europe: Reshuffling the borders of order' Thesis Eleven 136(1): pp. 54-73.

Wolzcuk, K. (2017) 'Ukraine in the European Neighbourhood Policy' in Schumacher, T., Marchetti, A. and Demmelhuber, T. (eds) The Routledge Handbook on the European Neighbourhood Policy. Oxford: Routledge, and New York: Routledge, pp. 279-288.

Vasilyeva, N. (2018) 'Russia: Missile that shot down flight MH17 was Ukrainian', Associated Press, 17 September. Available at: https://www.apnews.com/f53b42ce3aab44308730eb2d89c9e545 (retrieved on: 13 October 2018).

Zeitzoff, T. (2017) 'How Social Media is Changing Conflict' Journal of Conflict Resolution 61(9): pp. 1970-1991. 


\section{GLOBAL SECURITY ASSEMBLAGES: MAPPING THE FIELD}

\section{Jovana Jezdimirovic Ranito}

jovanaranito@gmail.com

Post-Doctoral Researcher at the University of Porto and External Examiner for Diploma Program in Global Politics at the International Baccalaureate Organization. She holds PhD in international politics and conflict resolution from the University of Coimbra. Her area of expertise includes private security governance, regulation of private security contractors, and dynamics between public and private security/military forces. Her most recent publication is Regulating US Private Security Contractors, published in 2019 by Palgrave Macmillan

\section{Abstract}

Global security assemblages' concept, in a decade of its existence, has been a useful tool to explain a lot of atypical security collaboration between private and public entities. It has greatly improved understanding of collaboration between public and private security forces, which, until then, mostly ha0s been seen through the civil-military paradigm. Through the expansion of scenarios where private security forces have been observed (to include environments not considered either at war or in peace, but somewhere in between) global security assemblages demonstrated, on numerous occasions, examples that cooperation between private and public forces may contribute to the improvement of the global security environment.

Hence, how far can we stretch this concept? Private entities operate at numerous places and contexts and the concept may be a limited tool to understand their input in achieving a more stable environment. It has been set to apply in peaceful settings, but would it be possible to extend its application in unstable environments, within unpredictable security settings? This paper looks at how the concept has been used and applied so far, the scope where it can and has been applied, and draw the limitations to its use.

\section{Keywords}

Global security assemblages; private security; conflict; civil-military relations; public-private relations

\section{How to cite this article}

Ranito, Jovana Jezdimirovic (2019). "Global Security Assemblages: mapping the field". JANUS.NET e-journal of International Relations, Vol. 10, N.o 2, November 2019-April 2020. Consulted [online] on the date of the last visit, https://doi.org/10.26619/1647-7251.10.2.5 


\title{
GLOBAL SECURITY ASSEMBLAGES: MAPPING THE FIELD ${ }^{1}$
}

\author{
Jovana Jezdimirovic Ranito
}

Global security assemblages' concept arose as a response to the long quest for a suitable framework under which cooperation and dynamics between private and public actors providing security can be studied. Strong reintroduction of use of private security in mainstream policies by states since the beginning of the century, aside from their evergrowing use by the private sector, caused serious difficulties in studying dynamics between new actors and their interactions with state forces and/or institutions. The first wave of literature sought historical references on how to address these new actors, and found fertile ground in comparison to mercenaries, after some of the more serious incidents caused by those forces under government contracts (Fidler, 2007; Pelton, 2007; Singer, 2004). The mostly unknown mode (to the general public) in which they are employed, rules of their engagement, and limited institutional and legal frameworks under which these new actors would be categorized, caused hitches in their better understanding (Silverstein, 1997; Brooks, 2000; Singer, 2003; Kinsey, 2005; Krahmann, 2005a). The misunderstanding of the evolution of the private security industry - and the perception by the general public that they are mercenaries - was the principal challenge faced in the early years. On the one hand, Silverstein (1997), Brooks (2000) and Singer (2003) contributed by shedding a light on the industry and the new contexts within which they are employed. On the other hand, Kinsey (2005) and Krahmann (2005a) highlighted the inadequate legal framework to deal with the private security industry, instead of mercenaries.

Security governance literature has addressed aspects of the inclusion of non-state actors (and particularly private security companies) in the institutional framework (Bryden \& Caparini, 2006; Bures \& Carrapico, 2017; Krahmann, 2010). However, few options were available to observe everyday dynamics between state and private security actors. Certainly, the most problematic issue for academics was the approach used to accomplish it; namely, after the expansion of the use of private security to stability operations and post-conflict setting. Avant $(2004,2005)$ addressed the power exchange issue by looking at how effectively on the ground and in the decision-making process power related to security decisions previously monopolized by states has been influenced by the private security companies working for them. She acknowledged difficulties in applying any IR approaches to issues associated with private security companies, since those actors and interactions represent new realities that we have not seen before (Avant, 2006). Another commonly used approach to address cooperation between private security forces and state institutions is through civil-military relations/cooperation. From looking how these

1 Special issue of articles presented at the 1st International Conference on Conflict Resolution and Peace Studies that took place at UAL on the $29^{\text {th }}$ and $30^{\text {th }}$ of November 2018. 
work together on the ground and problems they face from diverse cultures they have (Bruneau, 2011; Herbst, 2007; Holmqvist, 2005), to observing it as a governance matter (Krahmann, 2005b), to seeking answers within network theories (Avant, 2016; Krahmann, 2016), academics have struggled to apply knowledge from the ground to existent frameworks.

In such settings, there was a need for another approach that would facilitate the study of not only the military outsourced security (by some states), but also to expand analysis on commercial security services provided globally that linked state institutions and private actors. In 2009, Abrahamsen and Williams proposed a new tool to study the impact of and relations between private security companies and state actors, related to commercial use of security. Global security assemblages proposed to look at how, in practice, private security companies may affect security settings on the ground. The greatest innovation was the possibility to observe dynamics closely between private and public actors and to focus on the empirical data.

A decade has passed since its first introduction and here the focus is given to the utility of this concept so far. The contribution I seek to make is to present a balanced overview of the last decade, examining this concept through a literature review focusing on how the realities have become ever more complex and are not explicable by utilizing other approaches, such as security governance of actor-network theories. I shall attempt to demonstrate that it has gained ground on its own merit, although it has served as an inspiration to other concepts that have derived from it. Finally, this paper will explore the challenges that the global security assemblages concept is now facing with the growing complexity of security environments, namely the analysis of the inclusion of new actors like terrorists, rebels and various criminal groups.

To accomplish it, I address where this concept has been applied so far and with what purpose. Then I draw on its limitations that have been recognized and question its relevance a decade after being introduced. I make a critical analysis of the most important literature published in a decade of its existence and I seek to include the wide range of issues that have been explored. The article is divided into four parts, as follows: In continuation, I address the concept itself and explain its main features and aims. Then, I look at where geographically, thematically, and by which disciplines it has been used so far. Then, I draw the limitations of the concept. Finally, I conclude that even though there are a lot of benefits in using this approach, there are certain restrictions as well, and recommend new research areas.

\section{Global security assemblages concept - what it is and why we are using it?}

The concept of assemblages is not new and has been used in various disciplines through previous decades. Originally, concept and theory of assemblages were introduced by French philosophers Deleuze and Guattari (1987), and, after them, it has been widely used and developed within sociology and political science. Deleuze's contributions to assemblage thinking have been widely accepted, but it's rudimentary and rather scattered thoughts rather than articulated theory have been recognized as well (DeLanda, 2006, p. 3). Deleuze and Guattari established the concept of assemblages, still primordial in articulation but containing three essential elements: abstract machine, concrete element, and personae. As Nail (2017: 23-24) stressed, for Deleuze and 
Guattari assemblages are like abstract machines as they a) do not exist as a thing/object in the world but are rather a set of external relations that surround elements and agencies, and b) are networks of specific external relations defined by composition, mixture, and aggregation. Assemblages also need to have a concrete element, an existing embodiment of assemblages, as a skeletal frame or archipelago (Nail, 2017: 26). Finally, the personae of the assemblages are agents that cannot be observed and studied independently, as they are mobile operators that connect concrete elements together according to their abstract relations. Deleuze and Guattari give examples of a runner or an intercessor, stating that "persona is needed to relate concepts on the plane, just as the plane itself needs to be laid out" (Deleuze \& Guattari, 1996: 73-76).

In 2006, DeLanda presented what he considered to be an improved version of assemblage theory, which he considered to be version 2.0 of Deleuze's or, as he called it, "neo-assemblage theory" (DeLanda, 2006: 4). His drive was to set assemblages theory free of the micro-macro divide and to allow a cross-level analysis of sociological entities and processes. The difference from the isolated concepts mentioned by Deleuze is in collecting certain elements of assemblage thinking and making analytical sense of them. For instance, he departed from Deleuze and Guattari's social ontology (individuals, groups and the social field), which he considered to be primitive, and extended it to international organizations and interpersonal networks. Also, he advances further by showing that assemblages must be fully "independent from our minds", calling on them to be autonomous, mind-independent agents. He departed from the recognition that exteriority of relations is an important assumption of assemblages. That implies assemblages are not firm and static formation; they may be separated in functional parts that interact with the other actors, but still, when they interact among themselves, their interactions may result in synthesis (DeLanda, 2006: 11). Moreover, he analyzes binomial relations between territorialization and deterritorialization and uses coding to analyze each element of interaction among those parts that form assemblage. DeLanda dedicated every chapter to a different kind of assemblage, to express the range of forms they may take: social (chapter 1), linguistic (chapter 2), martial (chapter 3), scientific practices (chapter 4), a diagrammatic of the actual and virtual (chapter 5), atomic, genetic and chemical (chapter 6) and scientific and mathematical solutions (chapter 7).

Through time, academics have been leaving their own mark on the concept of assemblages by extending its use and proposing new directions. The main advance from DeLanda's theorization is the assumption that assemblages should not be limited to theory, but rather considered as a way of thinking. As Acuto and Curtis (2014: 3) explained, applying a thinking tool to assemblages is "a feature that makes this approach less of a theory and more of a repository of methods and ontological stances towards the social". Others have begun introducing new aspects and theories to supplement assemblages thinking: Legg (2011) in conjunction with Foucault, Haraway with a feminist approach (Feigenbaum, 2015), and McCann and Ward (2012) with an application to study of policy. Even though each application has its own idiosyncrasies, assemblages thinking would have some core characteristics, like embracement of multiplicity, focus on practices of relation and ordering, a mixture of material and symbolic expressivity, and simultaneity of territorialization and de-territorialization (Bureš, 2015a: 17-18). Other common characteristics of all assemblage thinking are methods applied to accomplish it: ethnography, interviews, participant observation, and discourse analysis (Lisle, 2014: 70). 


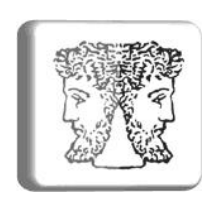

Global security assemblages is a concept drawn by Rita Abrahamsen and Michael Williams (2009b) with an aim to provide a framework to learn from the practices the impact private security companies have on security context where they operate. They departed from the Sassen (2008) notion of state disassembly that assumed reconfiguration of the state as we knew it before, in the western style democracies, and integration of non-state actors as active participants. The contribution of Sassen is not solely a recognition of the existence of non-state actors, as this had previously been done decades ago; however, she is the first to explain that the system founded on traditional agents needs to be disassembled and reassembled to bring in non-state actors as equal and active participants in governance structures. From there, Abrahamsen and Williams proposed a reassembly of how the security provision is perceived nowadays and include private security providers as an integral part of it.

Such an approach brought into the center of analysis, when it comes to private security, an important element that previously has been left aside: ethnography. Not limiting the descriptive nature of the ethnographic method, but using it as a departing point of analysis, global security assemblages' concept focuses on the integration of data collected from practices and its interpretation through two important - and up to then separate - paradigms: private/public and local/global. By using Bourdieu's concept of field ${ }^{2}$, Abrahamsen and Williams (Abrahamsen \& Williams, 2010) work on reassembly of our perceptions of where the public sphere terminates and where the private begins. They used the concept as an analytical liberation from heavy theoretical constraints and assume that the concept is constructive and deeply interconnected with empirical findings (2014a: 27). It steps up from the linear understanding of the place and role of actors involved in the informal security governance (setup) in certain places, as in Africa, where western conceptualization of how things occur is not applicable (Abrahamsen, 2017). They made a huge step by setting aside, up to then, used network theories to explain how security actors cooperate and work at the same place. Their conceptual set up is leaning on Bourdieu's concepts of capital and power, allowed both solidification of theoretical ground and setting some conceptual boundaries, and in the same time openness to adapt it to be applicable in the realities that are not western democracies. Even though they admit slippages between Bourdieu's field theory and assemblages, it is clear that Bourdieu's field theory is not applicable in its entirety here (Abrahamsen \& Williams, 2014b: 27). Concept of field simply is not extendable to a global scale and, therefore, significant adjustments were necessary. However, it permitted freedom to set non-linear, non-network sets of actors, and to admit transformational nature and characteristics when it comes to the power they hold and capital they have.

The reassembly of our security perception extends to a distinction between a local and global, and public and private, and the crucial point is that the traditional western-centric definition of the state and institutions run by it have a very different version in the nonwestern world; and those concepts will not do justice to analysis that is done, simply because they are not reflecting requirements that those concepts hold in western

2 The field represents a social space that goes beyond locating objects of analysis within historical, spatial (local, national, international), and relational context, and includes comprehension of how previous knowledge was generated, by whom, and whose interests were served by those practices (Bourdieu, 2000a, 2000 b). The analogy sometimes is given to a certain sports game field: they are shaped according to the game that is played; it has its own rules, its own star players, histories, legends, and lore (Thompson, 2014: 67). Agents do share more than one field simultaneously, varying in generality and scope, and include both professional and private spheres of life. 


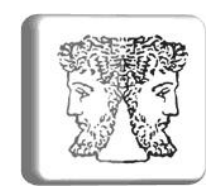

tradition (Abrahamsen, 2017). Their examples through Africa demonstrate blurring lines among benefits in security, considering the action of private companies and "public" forces (Abrahamsen \& Williams, 2010). The same way, those public entities are considered local, but with input and cooperation with global security companies, the security outputs may not be constricted on the action of either separately (Williams, 2016).

\section{Where and how it has been employed so far?}

This approach has been embraced by the academic community globally as it opened up a space for a study of the commercial private security companies beyond conflict zones, still in a context of public-private security provision and use as military support. Private companies and NGOs globally have been using private security companies to secure their operations and assets in remote and challenging environments (Avant, 2007: 457; Omeje, 2017). The mining and gas exploration companies have been heavily using these agents since the early 1990 s and their use has exponentially grown (Börzel \& Hönke, 2010; Ferguson, 2005; Kirshner \& Power, 2015). The most notable outcome was an acknowledgment that private security providers have caused some positive impact in the communities where they conduct their operations. They introduced higher operational standards, approximated human rights respect in local communities, and overall increased the perception by the local population of a more secure environment (Abrahamsen \& Williams, 2007; Campbell, 2006). This was accomplished, for instance, by providing training to local security groups (either formal or informal), transcending the security efforts to the local community (from solely on the grounds of the contracting company) or offering workshops to the local population on conflict resolution techniques. The main benefit has been the ability to look at the everyday practices and dynamics that occur between private security providers and state forces. Such benefit may be seen in the research both in developing and developed countries, even though the concept was set having in mind countries where western concepts were not fully applicable. As Abrahamsen and Williams (2014a) explained, the western concepts and attempts to apply them to underdeveloped settings have severely failed. Global security assemblages allowed the perception of how the security sector is established and running in Africa. In a sense, they opened up vocabulary and offered tools for western society to research and get a grasp of workings of the security sector in Africa.

To follow the geographical focused on Africa used by Abrahamsen and Williams, the concept was also used to demonstrate practices in Tanzania (Abrahamsen \& Williams, 2017), Liberia (Abrahamsen and Williams, 2009a; Mohlin, 2017), Somalia (Cunha, 2017; Reno, 2017; Sandor, 2016), Democratic Republic of Congo (Schouten, 2011, 2017), Nigeria, and South Africa (Abrahamsen \& Williams, 2010). Those works delved deeply into how these interactions between private security companies and non-state local agents serve as a substitute/supplement for public service and how they effectively contribute to the improvement of the local security environment.

Besides across Africa, the concept has been used to study the Middle East and Europe as well. For instance, Tholens (2017) approached how global security assemblages have been constituted in the post-2011 the Middle East. And, Hazbun (2016) looked at the Lebanese reality and used it to contextualize the state of the security sector in this country. In the European settings, Bures (2015a) used it to dismantle and reassemble 
operations of the private security industry in the Czech Republic. He analyzed various assemblages - private and public, and all in between - and shed light on the complex world of the private security industry in a social context within one country. More recently, Borrajo Valiña (2018) explored emergence of the European Union comprehensive approach, based on global security assemblages, to address recent external conflicts and crisis. Before them, Berndtsson and Stern (2011) applied it in analysis of the operations of Stockholm airport security. Van Steden and De Waard (2013) applied it to what they called McDonaldization of private security industry across Europe, where commercial private security with neoliberal doctrine has been expanded to cover the areas that state would not.

With regards to the sectorial approach, in addition to being used as it was originally intended and imagined within the 'Peace' and 'Conflict' audience - to explain the dynamics between untraditional private-public and local-global actors in the developing world - several other approaches and disciplines have also found this concept to be useful. The range goes from the feminist perspective, over sociology, to criminology. For instance, in the feminist perspective, research looked at how global security assemblages affect contractors' households (Chisholm \& Eichler, 2018) and how gender is affected by private security in global politics (Eichler, 2015). Within the sociology approach, Bongiovi (2016) used global security assemblages to demonstrate the setup and operations of the 2012 Olympic Games in London. In criminology, it has been used to explore various aspects of policing (Abrahamsen \& Williams, 2007; Albrecht, 2017; Diphoorn, 2015).

The range of issues that are explored by this approach is wide: from looking over border control and protection of drug trafficking (Sandor, 2016), to its application to extractive industries (Abrahamsen \& Williams, 2017), to its significance to larger security governance around the globe (Bureš, 2015b; Cunha, 2017; Hazbun, 2016; Hönke \& Müller, 2012) or policing (Abrahamsen \& Williams, 2007; Albrecht, 2017; Diphoorn, 2015), and it will be certainly expanded further.

Moreover, Abrahamsen and Williams's concept served as an inspiration for others who adjusted it and used it in their own research within the field of security governance and beyond. Within security governance research - while Abrahamsen and Williams established the global security concept as a tool to distance from agent-network theories - it is interesting to watch how Schouten (2014) departs from it to look at global security assemblages' broader impacts on security governance and suggests that the agentnetwork theory widens the scope of what security assemblages are. Within security studies, Collier (2018) departed from the philosophy behind the concept and adjusted it to address cybersecurity reality. Mary Kaldor (2018) took a more sociological turn and used it as a departure for establishing the global security culture concept.

As we could see, this concept is transversal from the point of view of disciplines, geographical areas, and topics where it has been useful and applied. From IR, sociology, and criminology; to overlooking Africa, Middle East and Europe; to security governance, policing, border control, and extractive industry, the scope of the concept is wide. We could also see that it has inspired others to adapt it and apply the same philosophy to other areas, as in the case of cybersecurity and security cultures.

However, when working with this concept, academics recognized some constraints and limitations to apply the concept, particularly when trying to expand on the areas that are not security stable. 


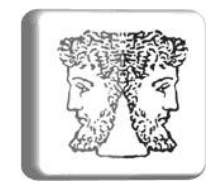

\section{Limitations and constraints of the concept}

The last decade demonstrated that there was a dire need for a concept that will allow looking at dynamics between private and public forces beyond beholding over power relations but at how they impact security environments on the ground. It brought significant empirical data to the surface and produced practical knowledge about how those assemblages work in various points of the globe. However, some constraints of the concept, as proposed by Abrahamsen and Williams, are becoming more visible. The use of the concept has been stretched to accommodate diverse scenarios worldwide, as we previously saw. The fact is that the world is more complex than it was a decade ago when the concept was introduced. Those complexities, because of the concepts of global security assemblages, are now more visible than they used to be. While before there was more accent on public-private and global-local divisions, this concept allowed observing everyday practices that show blurred lines between them. That permitted seeing more in detail actors involved in assuring security in local communities, for example the local private security group Sungusungu in Sierra Leone, which assumed responsibility for the resolution of over $90 \%$ of local disputes because their coverage of local areas is much greater than that of the public forces (Albrecht, 2017). Also, it exposed an increasing range of actors to be considered in such assemblages, as well as complex circumstances where there are actors in the same space providing different dynamics at different times, as was the case of the rebel group in Kenya that originally contributed to making the environment more volatile, but then turned into a legitimate political force who eventually contributed to the stabilization and expanding of the security situation (Rasmussen, 2017).

Nowadays, there are many scenarios where we cannot make a simple distinction between the commercial use of private security and military use, as a decade ago it was. In that sense, even though Abrahamsen and Williams (2014b, p. 26) claim the concept to be more of a descriptive term than it carries on theoretical baggage, it crosses with many challenges to apply in more complex settings, where security may be evaluated to be between war and peace. As the departing assumption of the concept is that public and private local and global actors do work together (intentionally and coordinated, or not) with an aim to accomplish more stable security environment, particularly in the challenging place like many given examples across Africa. Hence, there are other actors (global, local, public, and private) who might not work in such linear mode, who might gain more from destabilization of the region that contributing to its stabilization.

That is the situation that Didier Bigo (2014: 208) identified as "messiness of the world" and called on impossibilities to establish clear and absolute boundaries. He insists on the claim that divisions as war and crime, violence, and security not only are not helpful for the understanding of the current practices that occur around the globe, but they are, in fact, harmful. Division of the agents and their role to a certain scenario, i.e., the police is dealing with internal treats vs army that deals with threats across the border are refuted by practices as invalid. Moreover, the gains and risk that certain agents represent in the broader understanding of security in certain regions may be misleading if the risk assessment does not include crime and corruption as well. While Abrahamsen and Williams looked exactly in overcoming some divisions (public-private and global-local), 


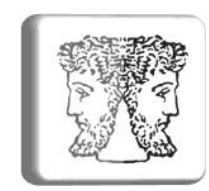

their focus was on how those dynamics work with the final aim to see benefits for a local security context.

In a line with Bigo's concerns, Doucet (2016) recognizes the merits of the global security concept but demonstrates that such a concept is limited in the analysis of more complex realities, such as modern-day interventions. Because of the multiplication of the agents (both commercial and military use) involved and trying to use the concept in the areas where stability is still volatile (as post-conflict or stability operations), the concept has been stretched to its limits. It was not drawn to cover those circumstances, yet its core philosophy would be adequate for thinking about how those assemblages do work.

Even when considering somewhat stable environments, there are new hybrid forms of assemblages that go beyond private companies and public institutions and call on the importance of traditional leaders or locally organized security groups, considered nonstate actors, as the crucial part of the local security dynamics in the developing world. Peter Albrecht (2017) demonstrated the weight such non-state actors carried in the Sierra Leone where the private security actor Sungusungu assumed informal responsibility for the resolution of community conflicts where there was an absence of public forces. Those actors, by being involved in such hybrid assemblages, may gain the political significance they previously did not possess, as happened in Kenya where the rebel group evolved into a legitimate political force (Rasmussen, 2017).

There is a growing literature on the other actors - such as terrorists, rebels, warlords, and other criminal groups - that turn security analysis even more complex (Varin \& Abubakar, 2017). The exclusion of the terror-crime nexus when analyzing security assemblage at certain locations can cause significant alteration of the results and limit understanding of dynamics and actors relevant in certain security contexts. For instance, Frowd and Sandor (2018) demonstrated this to be relevant in the Sahel case, but certainly, this is applicable in many others. As mentioned above, expansion of what is considered a relevant private actor (i.e., commercial private security company) a decade ago, is much wider now when there are, besides local groups and traditional leaders, also other groups that contribute - positively and/or negatively - to the security environment locally. There are global actors, such as radicalized and extremist groups that contribute to alterations in security dynamics in certain regions that cannot/should not be dismissed. Difficulties to include such groups within analysis provided by global security assemblages is noticed (Ismail, 2013).

Finally, the dificulty of the global security assemblages' concept is in considering all these dynamics and acknowledging the complexity of the input of various actors involved. Some of those actors may contribute positively at one time, while negatively at other. Also, there may exist a number of positive and negative inputs at the same time that would not necessarily result in a stable local security environment.

\section{Conclusions}

This article presented a literature review of a global security concept. After explaining its origins and aims, it explored its space within various disciplines, from political science, over sociology, to criminology. The use of the concept has been diverse, both from the point of the view of the topics and geographically. It has been employed to address issues 
so distinct as policing, border control, extractive industry, gender roles, and security governance. Geographically, it covered Africa, Europe, and the Middle East.

We presented the benefits of using this approach as an alternative to actor-network theories and security governance approaches that have dominated academic literature concerning the analysis of private security actors. It provided the openness to study dynamics of private and public actors and their practices, to learn from empirical data, and to go beyond power relations analysis and set aside private-public and global-local divisions, just some to name. In a decade of its use, it is a valuable tool academics use to think about relations of private security at places that defy previously established concepts and dichotomies.

The concept as a thinking tool has been useful as an inspiration to others to set their own adaptations, like Kaldor's global security cultures or Collier's global cyber security assemblages.

Hence, there are some challenges it has come across, as every growing complexity of actors, dynamics, and settings in which we can observe security assemblages, such as more hybrid forms, which include other non-state actors, the change of dynamics within and between them, as well as more volatile settings are just some of them. Those challenges represent a window of opportunity to explore further options as an inspiration to others to look at it as a departing thinking tool to form perhaps the possibility to study those adding complexities in the future.

\section{References}

Abrahamsen, R. (2017). Africa and international relations: Assembling Africa, studying the world. African Affairs, 116(462): 125-139.

Abrahamsen, R., \& Williams, M. C. (2007). Securing the city: private security companies and non-state authority in global governance. International Relations, 21(2), 237-253.

Abrahamsen, R., \& Williams, M. (2009a). Security Beyond the State: Global Security Assemblages In International Politics. International Political Sociology, 3: 1-17.

Abrahamsen, R., \& Williams, M. C. (2009b). Security beyond the state: Global security Assemblages in international politics. International Political Sociology, 3(1), 1-17.

Abrahamsen, R., \& Williams, M. C. (2010). Security Beyond the State: Private Security in International Politics. Cambridge: Cambridge University Press.

Abrahamsen, R., \& Williams, M. (2014). Tracing Global Assemblages, Bringing Bourdieu to the Field. In Reassembling International Theory. Springer: 25-31.

Abrahamsen, R., \& Williams, M. (2017). Golden Assemblages: security and development in Tanzania's gold mines. In P. Higate \& M. Utas (Eds.), Private security in Africa: from the global assemblage to the everyday. London: Zed Books. Londres: Zed Books: 1531.

Acuto, M., \& Curtis, S. (2014). Assemblage Thinking and International Relations. In M. Acuto, M. \& Curtis, S. (Eds.), Reassembling International Theory. Basingstoke: Palgrave Macmillan: 1-14. 
Albrecht, P. (2017). Private Security beyond private sector: community policing and secret societies in Sierra Leone. In P. Higate \& M. Utas (Eds.), Private Security in Africa: From Global Assemblage to the Everyday. Londres: Zed Books: 52-69.

Avant, D. (2004). The Privatization of Security and Change in the Control of Force. International Studies Perspectives, 5(2): 153-157.

Avant, D. (2005). The Market for Force: The Consequences of Privatizing Security. Cambridge: Cambridge University Press.

Avant, D. (2006). The Implications of Marketized Security for IR Theory: The Democratic Peace, Late State Building, and the Nature and Frequency of Conflict. Perspectives on Politics, 4(3): 507-528.

Avant, D. (2007). Contracting for Services in U.S. Military Operations. PS: Political Science \& Politics, 40(3): 457-460.

Avant, D. (2016). Pragmatic Networks and Transnational Governance of Private Military and Security Services. International Studies Quarterly, sqv018.

Berndtsson, J., \& Stern, M. (2011). Private security and the public-private divide: Contested lines of distinction and modes of governance in the Stockholm-Arlanda security assemblage. International Political Sociology, 5(4): 408-425.

Bigo, D. (2014). War and crime, military and police: the assemblage of violence by security? In J. Bachmann, C. Bell, \& C. Holmqvist (Eds.), War, Police and Assemblages of Intervention. Routledge: 204-213.

Bongiovi, J. R. (2016). Public-Private Global Security Assemblages (Londres 2012). In V. Bajc (Ed.), Surveilling and Securing the Olympics:359-380.

Borrajo Valiña, D. (2018). European governance and global security Assemblages: the emergence of the European Union's comprehensive approach to external conflicts and crises (2009-2017) (Tese de Doutoramento). http://hdl.handle.net/10810/24433

Börzel, T., \& Hönke, J. (2010). From compliance to practice: mining companies and the voluntary principles on security and human rights in the Democratic Republic of Congo.

Bourdieu, P. (2000a). Pascalian Meditations. Londres: Polity.

Bourdieu, P. (2000b). Propos sur le champ politique. Lyon: Presses Universitaires de Lyon.

Brooks, D. (2000). Messiahs or mercenaries? The future of international private military services. International Peacekeeping, 7(4): 129-144.

Bruneau, T. (2011). Patriots for Profit: Contractors and the military in the US national security. Stanford, CA: Stanford University Press.

Bryden, A., \& Caparini, M. (2006). Private Actors and Security Governance. Genebra: DCAF.

Bureš, O. (2015a). Global Security Assemblages: Enhancing Assemblage Thinking with Bourdieu's Sociology. In Private Security Companies. Springer: 13-34.

Bureš, O. (2015b). Private Security Companies: Transforming Politics and Security in the Czech Republic. Springer. 
Bures, O., \& Carrapico, H. (2017). Security Privatization: How Non-security-related Private Businesses Shape Security Governance. Springer.

Campbell, B. (2006). Good governance, security and mining in Africa. Minerals \& EnergyRaw Materials Report, 21(1): 31-44.

Chisholm, A., \& Eichler, M. (2018). Reproductions of Global Security: Accounting for the Private Security Household. International Feminist Journal of Politics.

Collier, J. (2018). Cyber Security Assemblages: A Framework for Understanding the Dynamic and Contested Nature of Security Provision. Politics and Governance, 6(2): 1321.

Cunha, P. B. (2017). Somalia as a Market for Private Military and Security Companies: definitions, agents and services. In A. Magnólia Dias (Ed.), State and Societal Challenges in the Horn of Africa: Conflict and processes of state formation, reconfiguration and disintegration: 78-89.

DeLanda, M. (2006). A new philosophy of society: Assemblage theory and social complexity. A\&C Black.

Deleuze, G., \& Guattari, F. (1987). A thousand plateaus: Capitalism and schizophrenia. Minneapolis: University of Minneapolis Press.

Deleuze, G., \& Guattari, F. (1996). What Is Philosophy? Columbia University Press.

Diphoorn, T. G. (2015). Twilight policing: private security practices in South Africa. British Journal of Criminology, 56(2): 313-331.

Doucet, M. G. (2016). Global Assemblages of Security Governance and Contemporary International Intervention. Journal of Intervention \& Statebuilding, 10(1): 116.

Eichler, M. (Ed.). (2015). Gender and Private Security in Global Politics (1 a edição). Nova Iorque: Oxford University Press.

Feigenbaum, A. (2015). From cyborg feminism to drone feminism: Remembering women's anti-nuclear activisms. Feminist Theory, 16(3): 265-288.

Ferguson, J. (2005). Seeing like an oil company: space, security, and global capital in neoliberal Africa. American Anthropologist, 107(3): 377-382.

Fidler, S. (2007, January 10). Civilian workers could face court martial. Financial Times.

Frowd, P. M., \& Sandor, A. J. (2018). Militarism and its limits: Sociological insights on security Assemblages in the Sahel. Security Dialogue, 0967010617739534.

Hazbun, W. (2016). Assembling security in a 'weak state: 'the contentious politics of plural governance in Lebanon since 2005. Third World Quarterly, 37(6): 1053-1070.

Herbst, K. (2007). Private Security Companies and Civil-Military Cooperation. In T. Jager \& G. Kummel (Eds.), Private Military and Security Companies: Chances, Problems, Pitfalls and Prospects: 273-291.

Holmqvist, C. (2005). Engaging Armed Non-State Actors in Post-Conflict Settings. In A. Bryden \& H. Hänggi, Security Governance in Post-Conflict Peacebuilding. Munster: Lit Verlag: 45-68. 
Hönke, J., \& Müller, M.-M. (2012). Governing (in) security in a postcolonial world: Transnational entanglements and the worldliness of 'local'practice. Security Dialogue, 43(5): 383-401.

Ismail, O. (2013). Radicalisation and violent extremism in West Africa: implications for African and international security. Conflict, Security \& Development, 13(2): 209-230.

Kaldor, M. (2018). Global security cultures. John Wiley \& Sons.

Kinsey, C. (2005). Challenging international law: a dilemma of private security companies. Conflict, Security \& Development, 5(3): 269-293.

Kirshner, J., \& Power, M. (2015). Mining and extractive urbanism: Postdevelopment in a Mozambican boomtown. Geoforum, 61: 67-78.

Krahmann, E. (2005a). New threats and new actors in international security. Nova Iorque: Palgrave Macmillan.

Krahmann, E. (2005b). Security governance and the private military industry in Europe and North America. Conflict, Security \& Development, 5(2): 247-268.

Krahmann, E. (2010). States, Citizens and the Privatisation of Security. Cambridge: Cambridge University Press.

Krahmann, E. (2016). NATO contracting in Afghanistan: the problem of principal-agent networks. International Affairs, 92(6): 1401-1426.

Legg, S. (2011). Assemblage/apparatus: using Deleuze and Foucault. Area, 43(2): 128133.

Lisle, D. (2014). Energizing the international. In Michele Acuto \& S. Curtis (Eds.), Reassembling international theory. Springer: 67-74.

McCann, E., \& Ward, K. (2012). Policy Assemblages, mobilities and mutations: Toward a multidisciplinary conversation. Political Studies Review, 10(3): 325-332.

Mohlin, M. (2017). Security Sector Reform as Trojan Horse? The new security Assemblages of privatized military training in Liberia. In P. Higate \& M. Utas (Eds.), Private Security in Africa: From Global Assemblage to the Everyday. Londres: Zed Books: 107-119.

Nail, T. (2017). What is an Assemblage? SubStance, 46(1): 21-37.

Omeje, K. (2017). High Stakes and Stakeholders: Oil Conflict and Security in Nigeria.

Pelton, R. Y. (2007). Licensed to Kill: Hired Guns in the War on Terror. Nova Iorque: Broadway Books.

Rasmussen, J. (2017). Political becoming and non-state emergence in Kenya's security sector: Mungiki as security operator. In P. Higate \& M. Utas (Eds.), Private Security in Africa: From the Global Assemblage to the Everyday. Londres: Zed Books: 120-141.

Reno, W. (2017). Failed, Weak or Fake State? The role of private security in Somalia. In P. Higate \& M. Utas (Eds.), Private Security in Africa: From the Global Assemblage to the Everyday. Londres: Zed Books Ltd.

Sandor, A. (2016). Border Security and Drug Trafficking in Senegal: AIRCOP and global security Assemblages. Journal of Intervention and Statebuilding, 10(4): 490-512. 
Sassen, S. (2008). Territory, authority, rights: From medieval to global Assemblages. Princeton University Press.

Schouten, P. (2011). Political topographies of private security in Sub-Saharan Africa. In African Engagements. Brill: 56-83.

Schouten, P. (2014). Security in action: How John Dewey can help us follow the production of security Assemblages. In Reassembling International Theory. Springer: 8390.

Schouten, P. (2017). Parapluies politiques: The everyday politics of private security in the Democratic Republic of Congo. In P. Higate \& M. Utas (Eds.), Private Security in Africa: From the Global Assemblage to the Everyday. Londres: Zed Books Ltd.

Silverstein, K. (1997, July 28). Privatizing war: How Affairs of State are Outsourced to Corporations beyond Public Control. The Nation.

Singer, P. (2004, April 15). Warriors for hire in Iraq. Salon. Disponível em: http://www.salon.com/2004/04/15/warriors/

Singer, P. W. (2003). Corporate warriors: the rise of the privatized military industry. Nova Iorque: Cornell University Press.

Tholens, S. (2017). Border management in an era of 'statebuilding lite': security assistance and Lebanon's hybrid sovereignty. International Affairs, 93(4): 865-882.

Thompson, P. (2014). Field. In Pierre Bourdieu: Key Concepts (pp. 65-80). Oxon; Nova Iorque: Routledge.

Van Steden, R., \& De Waard, J. (2013). 'Acting like chameleons': On the McDonaldization of private security. Security Journal, 26(3): 294-309.

Varin, C., \& Abubakar, D. (Eds.). (2017). Violent Non-State Actors in Africa: Terrorists, Rebels and Warlords (1st ed. 2017 edition). Nova Iorque, NY: Palgrave Macmillan.

Williams, M. C. (2016). Global Security Assemblages. In R. Abrahamsen \& A. Leander (Eds.), Routledge Handbook of Private Security Studies (p. section 13). Oxon; Nova Iorque: Routledge 


\title{
WHY IS IT IMPORTANT TO USE REGIONAL LENSES WHEN WE LOOK INTO CIVIL CONFLICTS IN THE MENA?
}

\begin{abstract}
Samer Hamati
Samerhamati@yahoo.com

$\mathrm{PhD}$ in Economics, School of Economics and Management, University of Minho (Portugal). He was Visiting Researcher in the Department of Political and Economic Studies, University of Helsinki. Expert of Social Capital Rebuilding in Syria, Training and Research Institute of Romania. Senior Researcher of Poverty and Inequality in a UNDP project of Establishing the National Social Welfare Fund in Syria, United Natons Development Programme Projects, Damascus, Syria. External Consultant of set the Food Security Strategy of Syria, Natonal Agricultural Policy Center, Syria. He got a Congratulation Notification approved unanimously from the Portuguese Parliament since he was the firts Syrian students obtaining PhD from Portugal. He has voluntary work experience.
\end{abstract}

\section{Abstract}

Investigating different political and social variables in the Middle East and North Africa (MENA) is receiving more attention between social scientists, particularly in the peace and conflict institutes. This is due to the uniqueness of the region and to the violent conflicts it has witnessed for the last decades. These conflicts become intrastate but transitional, hence transfer into internationalized civil conflicts, and have large externalities exceeding the region borders. These conflicts show the high connectedness between the MENA countries, and recently the Arab Spring affirms the 'contagion effect' of upheavals in the region. Following multidisciplinary approach, this research note is a try to explain how much important it is to study the MENA conflicts from a regional perspective and to present the factors proving the contagion effects there. We hope that when reading this note, the reader will sufficiently understand the regional aspects of the MENA conflicts.

\section{Keywords}

MENA; Contagion Effect; Civil Conflicts

\section{How to cite this article}

Hamati, Samer (2019). "Why is it important to use regional lenses when we look into civil conflicts in the MENA". JANUS.NET e-journal of International Relations, Vol. 10, N.0 2, November 2019-April 2020. Consulted [online] on the date of the last visit, https://doi.org/10.26619/1647-7251.10.2.6 


\title{
WHY IS IT IMPORTANT TO USE REGIONAL LENSES WHEN WE LOOK INTO CIVIL CONFLICTS IN THE MENA?
}

\author{
Samer Hamati
}

\section{Introduction}

For decades the MENA region at large has suffered from violence and experienced civil conflicts leading to a permanent atmosphere of instability. This violence became a normal way of ruling and transferring power since the modern political foundation of the MENA by the end of WWI. Skimming the modern MENA history, one can easily notice that there are shared historical characteristics where conflict trajectories have been similar between the countries. These shared characteristics extend to the political, social, and economic lives, establishing authoritarian and paternalistic regimes in the region and posing particular challenges for transitions and development process. Above all, these characteristics strengthen the links within this region and bring large interventions between the newly established states there. Understanding these interventions is key when studying peace and conflict in the MENA region.

Similar to the global trends, the number of conflicts in the MENA decreased significantly at the beginning of nineties and the region became stable after Kuwait's Liberation Process in 1991. This is clear when skimming the UCDP/PRIO Armed Conflict Database (Uppsala University, 2015). However, the number of conflicts jumps in the new Millennium, mainly due to the occurrence of civil conflicts. More specifically, anti-colonial and interstate conflicts have almost disappeared, and almost all of today's wars are interstate ones but with large international interventions, making them 'internationalized civil wars'. Moreover, these conflicts have been proxy-wars (Marshall, 2016). Pre-1990 conflicts were part of the Cold War with factions receiving support from their allies in Moscow or Washington. Starting from the end of Nineties, the competitors became regional and a cycle of regional proxy warfare, especially between Saudi Arabia and Iran, emerged (Nerguizian and Kasting, 2013). Conflicts in Syria, Iraq, Yemen, Bahrain, and Lebanon are clear examples.

The new waves of post-Arab Spring violence raise the awareness of civil conflicts exploding in the MENA region. It becomes clear that these conflicts are not purely 'civil'; besides, their consequences have gone beyond the MENA borders. Ross et al. (2011) argue that the Arab Spring affirms the 'contagion effect' of upheavals in the region. Based on reviewing the literature, the current note discusses the factors proving this contagion and emphasizing the regional perspective when investigating the civil conflicts in the MENA. We first briefly discuss this term, the MENA, and then we explain some 
characteristics of the MENA civil conflicts that make studying them key to support global peace and prosperity. We later clarify why it is better to look at these conflicts from a regional window. To do so, we follow multidisciplinary approach of analysis using brief social, economic, cultural, familial and historical anecdotal evidence. The note closes with two important notices.

\section{What do we mean by the MENA?}

The term the Middle East appeared centuries after the western concern of this region had increased. Since the Crusades, East, Orient, was identified with Islam and West, Occident, became identical with Christianity. The regions were thus symbolically divided according to two belief systems. Later, in the last quarter of the Eighteenth Century, Europeans referred to the territories controlled by the Islamic Ottoman Empire as the Near East, while Mahan and Chirol used the term the Middle East to call the Gulf of Aden and India in separate articles published in 1902 (Davison, 1960). Due to the political changes after WWI, a need to change the definition of the geographical area referred to as the Middle East appeared, and in March 1921, Winston Churchill, with the help of the Royal Geographical Society, was re-mapping the Middle East from the Bosporus to the western borders of India (Özalp, 2011). Later, this term appeared frequently in international literature.

However, notwithstanding the adoption of the term the Middle East in the international literature, there is no a common agreement on the extension of the geographical areas and the Middle East countries (Johannsen, 2009). Scholars have included different countries, although overlapped, when using this phrase. Many consider it the countries that were occupied by the Ottoman Empire (Tunçdilek, 1971; Brown, 1984; Tibi, 1989), others referred to it as the Islamic countries (Steinbach, 1979), some consider it as limited to the Arabic countries (Hudson, 1976), and a few have included more African countries such as Ethiopia (Davison, 1960). The major part of the recent literature define the MENA region as being made up of the Arabic countries, i.e., the twenty-two countries members of the Arab League, in addition to three non-Arabic countries whose actions contribute to the political and security situations in the MENA region: Turkey, Iran, and Israel, even though these states followed a somewhat different historical trajectory from the Arab states and have different economic structures that in the Arab countries (Owen, 2013).

\section{What does make civil conflicts in The MENA globally important?}

Not only just one factor makes civil conflicts in the MENA with global attention. Conflicts there last and their consequences are large and tragic. Nevertheless, the MENA position is the major reason for this global attention. Due to its strategic geographical position, the MENA region has witnessed many events whose causes and consequences have gone beyond its borders. Barakat (1993: 31) stated that "The centrality of the Arab World in ancient and modern times has qualified it to serve as an important nodal point in human history. It has acted as a passage connecting Asia, Africa, and Europe. It has produced some of the most important intellectual, cultural, and religious contributions of recorded history. It is this position at human and geographic crossroads, and not merely its oil and other resources that makes the Arab World so strategically significant". As a consequence 
of this central geographical position, conflicts have been frequent and characterized by attributes that make them distinctive from those occurring in other regions: sustainability, bloodiness, tragic consequences, and externalities.

Civil conflicts are sustainable in the MENA region. Parallel to internal conflict occurrence, a phenomenon referred to as the 'conflict trap' became more dominant. This trap refers to a situation when a post-civil conflict country falls again in another civil war. Walter (2015) finds strong evidence of a 'conflict trap'; 57\% of all countries that suffered from one civil war during the 1945-2009 period experienced at least one conflict thereafter. Furthermore, she points out that by the 2000s, $90 \%$ of all civil wars were repeated civil wars. Moreover, Collier (2007) shows that the risk of further conflict in countries emerging from civil war is almost twice as high as it was on the eve of that conflict. Further, Cevik and Rahmati (2015) find that this trap in tighter in the MENA region since countries in the Middle East appear to suffer from a high risk of conflict recurrence without much decline over subsequent years, leading to a sustainable sense of violence and insecurity there. This sustainability is one reason that increases the costs of MENA conflicts.

Civil conflicts in the MENA are costly in both terms: blood and money. The Syrian crisis, which is considered the "worst man-made disaster the world has seen since World War II", according to a UN officer (Al-Hussein, 2017), is recent top evidence for these costs; around $11.5 \%$ of the population were killed or injured in less than five years of conflict (SCPR, 2016). Besides, the region accounts for $40 \%$ of the estimated global total of battle-related deaths since 1946, according to the Uppsala Conflict Data Program. Regarding the high economic costs, Rother et al. (2016) argue that three years of conflicts following the Arabic Spring led to GDP losses of 6 to 15 percentage points in the MENA conflict countries compared with 4 to 9 percentage points worldwide.

These costs, furthermore, are not limited to the region, and other international costs appear. Indeed, the MENA conflicts generate large externalities represented by refugee outflows and energy-price fluctuations. Around two-thirds of current refugees worldwide come from the MENA. ${ }^{1}$ Refugees are not simply the unfortunate by-products of war, but may cause interstate conflicts (Posen, 1996). Salehyan (2008) claims that refugee flows between states increase the likelihood of militarized interstate disputes (MIDs) through two channels: Refugee-receiving states are more likely to initiate MIDs as they intervene to prevent further externalities, and refugee-sending states initiate MIDs as they violate borders in pursuit of dissidents.

Above all, energy-price instabilities are still the clearest externality caused by conflicts occurring in the MENA. This region owns $55 \%$ of global oil reserves (Guidolin and La Ferrara, 2010); and therefore any sort of tension there affects prices, output, employment, and economic growth worldwide. Two abnormal shocks in global economic graphs are strongly distinctive: one appeared in 1973-1974, and the other arose in 19791980. These shocks stemmed from two events occurring in the MENA region: the 1973's October (Yom Kippur) War and the 1979's Iranian Revolution. Using event study methodology to analyze the impact of conflict on a selection asset markets, Guidolin and La Ferrara (2010) find that the Middle East is very important for commodity indices including oil prices as $73 \%$ of conflicts occurring in this region have an impact on oil futures, and this impact is distinguishable from zero.

1 UNHCR. (2018, May 25). Figures at a Glance. Retrieved from: http://www.unhcr.org/figures-at-aglance.html 


\section{Why Is It Important to Study Civil Conflicts through Regional Context?}

The MENA countries are connected geographically, economically, and culturally showing a strong tendency for connectedness and contagion. The famous words of Elias Hrawi, the former President of Lebanon, when describing the civil conflicts in his home: "it was not our conflict, but others' in our land," attest to this (Atallah, 2008: 217). Therefore, one cannot investigate any civil conflict there in isolation from the regional context. This political and security interference is not just because of the common borders, but also because of the strong connections of their people where the majority hold similar beliefs, culture, and religion and share the same history.

The historical and cultural roots of connectedness are too deep and long. During the thirteen centuries preceding WWI, the majority of the region's territories were controlled by different powers that ruled through one ideology, Islam. The Ottoman Empire was the last great state controlling the region. Its fall finished the Caliphate and paved the way to construct modern artificial countries that host people sharing a common history, culture, alphabet, feelings and demographical connections including tribal relationships. Heydemann, as quoted in Yousef (2004: 95), points out that, "the region's exceptionalism is a recent phenomenon and in no sense a cultural one derived from intrinsic beliefs, values and norms in Arab-Muslim societies." These sharing values and senses prevent the creation of different identities in new-born societies, hence they validate Anderson's theory of 'imagined communities' (Anderson, 2006); communities within the Middle East are similarly produced, and engineer similar power hierarchies between them, leading to a strong collective imagining.

The establishment of the MENA modern states by the end of WWI explains the main part of this connectedness. The Allies, who won WWI, including Britain and France, divided the Arabic territories formerly occupied by the Ottoman Empire. Later, these colonial powers would create the key structures and the public management of the new states. Owen (2013: 9) discusses this development:

\footnotetext{
"As far as the Middle East was concerned, it was generally the dominant colonial power that first created the essential features of a modern state, by giving it a centralized administration, a legal system, a flag and internationally recognized boundaries. In some cases this was done on the basis of some pre-existing administrative entity, as in Algeria; in others it involved either detaching a part of a former Ottoman province (for example, Trans-Jordan) or, more usually, adding several provinces together (for example, Syria and Iraq). This gave many of the new states a somewhat artificial appearance, with their new names, their new capitals, their lack of ethnic homogeneity and their dead-straight boundaries that were so obviously the work of a British or French colonial official using a ruler."
}

These new states, with ill-defined nature (Milton-Edwards and Hinchcliffe, 2007), host people that belong to different ethnic, linguistic, and religious groups. Barakat said that 
"[c]ertain communities were imposed on others within the same country" (1993: 6). One year after the civil conflict erupted in Lebanon, Anne Sinai and Chaim Waxman argued in the introduction to the Middle East Review (1976: 5):

\begin{abstract}
"[T]he current civil war in Lebanon is but the latest and most publicized in a broad range of events and situations which belie the contention that the Middle East is a unitary world of Arabs with a common background, culture, language and identity. The Middle East in fact consists of an intricate mosaic of different peoples... There are Shi'ites... Alawites, Druze, Yazidis, Isma'ilies and followers of various other Muslim denominations, who cling determinedly to their own style of faith and their own set of beliefs. They are not even necessarily ethnically 'Arab,' being the descendants of many different peoples conquered and converted by the Islamic armies... The first of the three great monotheistic religions, Judaism, and the people with whom it is identical, have been part of the Middle East mosaic from their beginning... There are, in addition... other small religious groupings, each clinging to its own distinctive identity. No Arab state, thus, can claim societal homogeneity and all consist of major and minor religious, linguistic and ethnic groupings."
\end{abstract}

This heterogeneity created socially and culturally incomplete entities where ethnic and religious groups, as well as tribes and families, were divided between adjacent countries. Religious heterogeneity dominates other types of heterogeneity in the region. This heterogeneity has been coupled with discriminative procedures towards minorities. Fox (2013) finds that almost all the religious minorities in 17 Middle Eastern Muslim majority states experience religious discrimination. The literature shows that this discrimination, as well as other sorts of persecutions, can provoke surrounding countries to intervene in other countries to protect their ethnic kin (Saideman, 2001; Trumbore, 2003; Woodwell, 2004). Svensson (2013) finds a massive shift from nonreligious to religious conflict in the MENA region, making it the world region where religious armed conflict is most prominent. Svensson (2013) also argues that religious conflict in the MENA is long and transitional.

Furthermore, current economic ties, especially employment, support the social and cultural roots and make people of different MENA countries more connected. Millions of the migrant MENA labor force work in the rich Gulf countries, and their remittances support their families and their governments in their homelands. These remittances are not only financial but also social, meaning that migrants transfer new ideas, values, and behavior to their home countries (Levitt, 1998) having an influence on political attitudes and behavior of families staying in the homelands. Investigating the diffusion of political Salafism among Egyptians working in Saudi Arabia, Karakoç et al. (2017) find that the 
strongest support for the Nour Salafism Party came from individuals whose family members had immigrated to Saudi Arabia. ${ }^{2}$

Intra-trade and investment flows are other economic ties supporting Arabic connectedness. According to reports published by the Arab Monetary Fund (2017), many Arabic countries heavily rely on trading with other Arabic countries. Somalia, Djibouti, Jordan, Lebanon, Syria, Egypt, and Sudan export 91\%, 85\%, 50\%, 45\%, 40\%, 32\%, and $30 \%$ of their total exports respectively to other Arabic countries, while the intra-Arab investments jumped from 3\% to $15 \%$ of the total Arabic GDP between 2000 and 2008 due to oil-price booms.

Historical evidence confirms how much strong is the links between MENA countries, in particular, the Levante. We depict these strong connections by presenting two assassination murders happened in Summer 1951. On July 17, Riad Al-Solh, the first Prime Minister of Lebanon after independence, was assassinated in Amman, the capital of Jordan, by Micheal El-Deek, a Syrian person. Three days later, King Abdullah I, the first Jordanian King, was assassinated in Jerusalem by a Palestinian tailor. King Abdullah might have not been killed had he become a King of Iraq, as it was supposed. This point brings us to another important scope that confirms the strong regional links in the MENA. It is about tracing the lineages between elite families.

Genealogy is important between Arab tribes. Thus, it is key to understand the kinship between royal families in the region. Hussein bin Ali, Sharif of Mecca and the leader of Hashemites, allied with the British and rebelled against Ottomans. Two of his sons became kings: Faisal for Syria, and then Iraq, and Abdullah for Jordan. Another son, Ali, was the last King of Hejaz before he was defeated by his Ibn Saud, the founder of the Kingdom of Saudi Arabia.

We find a similar kinship but between Arabic political parties. Pan-Arabic nationalism parties have emerged during the last century, and many of them believes in the unity of Arabic countries. Take for example, Ba'ath Party in Syria and Iraq; Arab Socialist Union in Egypt; Popular Conference Party in Libya; and Socialist Party in South Yemen. All of these parties have been in power in their countries for years. Some had a friendly relation with others, and some were bad enemies. Ba'ath was the ruling parties in both Syria and Iraq, but the two factions were under strong conflict for decades.

Combined with soft budget constraints in the oil-exporting countries, these strong interconnections facilitate inter-country interventions. Above all, the military rule, common in most of the MENA countries, intensifies this trend. The domination of military rule over national political system in the region can be proved by the large number of military coups and revolutions. Milton-Edwards and Hinchcliffe (2007: 4) point that this "militaristic nature of the state in the region has a direct cause-and-effect relationship on the political processes of countries" there, and Picard (1993) argues that the statist preferences, mass politics, and anti-colonial struggles which existed in the post-Ottoman Middle East, lead to strong involvement of the military in politics. Those military governments appear to operate according to a logic of expansion and hence intervene in the political life of neighboring states.

2 Nour Salafism Party, which means Party of The Light, is one of the political parties created in Egypt after the 2011 Egyptian Uprising. It has an ultra conservative Islamist ideology, which believes in implementing strict Sharia law. 


\section{Final Remarks}

Watching daily news, the western observer is becoming aware of the violence appeared in the MENA region. Indeed, Karl Remarks' statement: "and then God created the Middle East and said, let there be breaking news and analysis", which became the title of his recent book published in 2018, attests to this. However, the western observer might be confused by the high degree of connectedness between these violent events. The current note, therefore, tries to shed light on the reasons behind this connectedness. It followed a multidisciplinary approach to explain why the domino effect has appeared in the region and why we should look at conflicts there, including civil wars, from a regional perspective.

It is important, before closing this note, to mention two important points. First, although unique as discussed in this note, the MENA region is a part of the Third World, hence it is subject to the same universal process of underdevelopment as other Third World countries, and one should put that in his mind when investigating conflicts there. In the preface of his book, Owen warns researchers not to explain everything happening in the MENA "by the fact that the majority of its people are Arab or Muslims who, until becoming rich from oil, lived as tribes in deserts" (2013: xii). Looking deeply at other conflicts in other regions of the world, for example, Sub-Saharan Africa, South Asia, the Balkans, and Latin America, many similarities can be seen within the reasons and consequences of civil conflicts.

Secondly, scholars should not ignore the specific characteristics of individual MENA countries. These countries are heterogeneous in terms of both economic and institutional development. One can easily notice this by skimming the economic figures and, more importantly, the human development index (UNDP, 2018). While all GCC countries are classified as very highly developed, Syria, Sudan, Yemen, Djibouti, Somalia, and Mauritania are classified in the lowest rank.

\section{References}

Al-Hussein. Z., R., (2017, March 14). A statement by the UN High Commissioner for Human Rights, Zeid Ra'ad Al Hussein. Retrieved from: https://news.un.org/en/story/2017/03/553252-syria-worst-man-made-disaster-worldwar-ii-un-rights-chief

Anderson, B. (2006). Imagined communities: Reflections on the origin and spread of nationalism. Verso Books.

Arab Monetary Fund. (2017). Statistics of inter and intra Arab trade competitiveness. Abu Dhabi. Retrieved from: http://www.amf.org.ae/en/page/statistics-inter-and-intraarab-trade-competitiveness

Atallah, S. (2008), Makal Al-Arbe'a: Mokhtarat etebaran men al-am alfeen [Wednesday Article: Selections since 2000]. Dar Al-Saki, Beirut. ISBAN: 1855169789.

Barakat, H. (1993). The Arab world: Society, culture, and state. University of California Press.

Brown, L. C. (1984). International politics and the Middle East: Old rules, dangerous 
game. IB Tauris.

Cevik, S., and Rahmati, M. (2015). Breaking the curse of Sisyphus: an empirical analysis of post-conflict economic transitions. Comparative Economic Studies, 57(4), 569-597.

Collier, P. (2007). The Bottom Billion: Why the poorest countries are failing and what can be done about it: Oxford University Press.

Davison, R. H. (1960). Where is the Middle East? Foreign Affairs, 38(4), 665-675.

Fox, J. (2013). Religious discrimination against religious minorities in Middle Eastern Muslim states. Civil Wars, 15(4), 454-470.

Guidolin, M., and La Ferrara, E. (2010). The economic effects of violent conflict: Evidence from asset market reactions. Journal of Peace Research, 47(6), 671-684.

Hudson, M. (1976). The Middle East. In J. Rosenau (Ed.), World Politics (pp. 476-500). New York: Free Press.

Johannsen, M. (2009). Der Nahost-Konflikt [The Middle East Conflict]. VS Verlag für Sozialwissenschaften.

Karakoç, E., Köse, T., and Özcan, M. (2017). Emigration and the diffusion of political Salafism: Religious remittances and support for Salafi parties in Egypt during the Arab Spring. Party Politics, 23(6), 731-745.

Levitt, P. (1998). Social remittances: Migration driven local-level forms of cultural diffusion. International Migration Review, 32(4), 926-948.

Marshall, A. (2016). From civil war to proxy war: past history and current dilemmas. Small Wars \& Insurgencies, 27(2), 183-195.

Milton-Edwards, B., and Hinchcliffe, P. (2007). Conflicts in the Middle East since 1945. Routledge.

Nerguizian, A., and Kasting, N. (2013). US-Iranian Competition in the Levant-II. Washington DC: Center for Strategic and International Studies.

Owen, R. (2013). State, power and politics in the making of the modern Middle East. Routledge.

Özalp, O. N. (2011). Where is the Middle East? The Definition and Classification Problem of the Middle East as a Regional Subsystem in International Relations. Turkish Journal of Politics, 2(2), 5-21.

Picard, E. (1993). La nouvelle dynamique au Moyen-Orient: les relations entre l'Orient arabe et la Turquie [The new dynamic in the Middle East: relations between the Arab East and Turkey]. Editions L'Harmattan.

Posen, B. R. (1996). Military responses to refugee disasters. International Security, 21(1), 72-111.

Ross, M., Kaiser, K., and Mazaheri, N. (2011). The resource curse in MENA? political transitions, resource wealth, economic shocks, and conflict risk. The World Bank.

Rother, M. B., Pierre, M. G., Lombardo, D., Herrala, R., Toffano, M. P., Roos, M. E., and Manasseh, M. K. (2016). The Economic Impact of Conflicts and the Refugee Crisis in the Middle East and North Africa. IMF Staff Discussion Note No. 16/08. The International Monetary Fund. 
Saideman, S. M. (2001). The ties that divide: Ethnic politics, foreign policy, and international conflict. Columbia University Press.

Salehyan, Idean. (2008). The externalities of civil strife: Refugees as a source of international conflict. American Journal of Political Science, 52(4), 787-801.

SCPR. (2016). Confronting Fragmentation. Syrian Center for Policy Research, Beirut. Retrieved from: http://scpr-syria.org/publications/confronting-fragmentation/

Sinai, A., and Waxman, C. (1976). Middle East Review, 9(1), 5.

Steinbach, U. (1979). Politisches Lexikon Nahost [Political lexicon Middle East]. München: Beck.

Svensson, I. (2013). One God, many wars: Religious dimensions of armed conflict in the Middle East and North Africa. Civil Wars, 15(4), 411-430.

Tibi, B. (1989). Konfliktregion Naher Osten. Regionale Eigendynamik und Großmachtinteressen [Conflict region Middle East. Regional momentum and major interests]. München: Beck.

Trumbore, P. F. (2003). Victims or Aggressors? Ethno-Political Rebellion and Use of Force in Militarized Interstate Disputes. International Studies Quarterly, 47(2), 183-201.

Tunçdilek, N. (1971). Güneybatı Asya. [Southwest Asia]. İstanbul: İstanbul University. Yay.

UNDP. (2014). Human development report 2016: Human Development for Everyone. United Nations Development Programme.

UNHCR. (2018, May 25). Figures at a Glance. Retrieved from: http://www.unhcr.org/figures-at-a-glance.html

Uppsala University. (2015). UCDP/PRIO Armed Conflict Database Version 4, 2015 UCDP. Uppsala, Sweden: Department of Peace and Conflict Research.

Walter, B. F. (2015). Why bad governance leads to repeat civil war. Journal of Conflict Resolution, 59(7), 1242-1272.

Woodwell, D. (2004). Unwelcome neighbors: shared ethnicity and international conflict during the Cold War. International Studies Quarterly, 48(1), 197-223.

Yousef, T. M. (2004). Development, growth and policy reform in the Middle East and North Africa since 1950. The Journal of Economic Perspectives, 18(3), 91-115. 


\title{
CHINA'S COOPERATION IN AFRICA IN THE AREA OF PHYSICAL CONNECTIVITY INFRASTRUCTURE. THE CASE OF THE MOMBASA-NAIROBI RAILWAY LINE
}

\begin{abstract}
María Noel Dussort
maria.dussort@fcpolit.unr.edu.ar $\mathrm{PhD}$ in International Relations at the National University of Rosario (UNR). Postdoctoral Fellow of the National Council of Scientific and Technical Research (CONICET, Argentina). Professor at the Faculty of Political Science and International Relations of the UNR and Coordinator of the Study Group on India and Southeast Asia of Rosario (GEIRSA). Researcher of the Studies Program on South-South Relations and Cooperation (PRECSUR) of the UNR. Research line: Energy security emerging powers, Brazil, India and China - oil producing countries of sub-Saharan Africa.
\end{abstract}

Agustina Marchetti

agustina.marchetti@fcpolit.unr.edu.ar PhD in International Relations from the National University of Rosario (UNR). Doctoral Fellow of the National Council of Scientific and Technical Research (CONICET, Argentina). Professor at the Faculty of Political Science and International Relations of the UNR and Coordinator of the Study Group on Latin America and Africa (PEALA). Researcher of the Studies Program on South-South

Relations and Cooperation (PRECSUR) of the UNR. Research line: China - Africa - South-South cooperation.

\section{Abstract}

In the 21st century, China proposes a cooperation scheme with its own characteristics. In relation to the cooperation projects that China has been carrying out in the African continent, an exponential growth of infrastructure works was observed that has contributed to the improvement of the socio-economic conditions of Africa. In this context, it is worth asking, what distinctive characteristics does Chinese cooperation in infrastructure have that makes it so attractive to African countries?

For the purpose of answering this question, we propose to analyse the link that Beijing has established with the African countries, specifying the characteristics its cooperation scheme presents. Likewise, the priority areas around which cooperation projects are directed and their financing modality are investigated. Secondly, we consider the construction of one of the sections of the railway in Kenya (Mombasa-Nairobi project) under the Belt and Road Initiative (BRI) as a typical case of China's infrastructure cooperation in an African country.

\section{Keywords}

China, cooperation, infrastructure, BRI, Kenya

\section{How to cite this article}

Dussort, María Noel; Marchetti, Agustina (2019). "China's cooperation in Africa in the area of physical connectivity infrastructure. The case of the Mombasa-Nairobi railway line". JANUS.NET e-journal of International Relations, Vol. 10, N.0 2, November 2019-April 2020. Consulted [online] on the date of the last visit, https://doi.org/10.26619/1647-7251.10.2.7

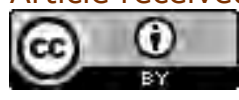




\title{
CHINA'S COOPERATION IN AFRICA IN THE AREA OF PHYSICAL CONNECTIVITY INFRASTRUCTURE. THE CASE OF THE MOMBASA-NAIROBI RAILWAY LINE ${ }^{1}$
}

\author{
María Noel Dussort
}

Agustina Marchetti

\section{Introduction}

Since the end of the nineties, it has been observed that China has displayed great international activism in all regions of the world and in most thematic areas, which have allowed it to gain greater prominence in the international system. In this sense, although the countries of Africa are not crucial in their expansion strategy 'outside borders', the truth is that they have gained priority in the design of their foreign policy.

Simultaneously to its internal modernization process, since 1999 the construction sector in China has grown by $20 \%$ annually, making this country the largest infrastructure market in the global economy. While Africa shows an unsatisfied demand in this regard as well as in the financing to undertake the necessary works, Beijing has not only accumulated substantial financial reserves but has become a global leader in construction services, with great experience in civil infrastructure development (Johnston, 2016). In other words, the complementarity is evident.

On the other hand, it should be considered that China's infrastructure cooperation in Africa is presented as an alternative to Official Development Assistance (ODA) provided by traditional powers, discursively governed under the Principles of Peaceful Coexistence ${ }^{2}$. However, in practice the "mutual benefits" are not tangible enough. It becomes questionable that the Asian country, being the second most important economy worldwide, claims to cooperate "on parity of conditions" with African countries by recognizing itself as a developing country.

In the new century there was a strong advance of Chinese state-owned companies in different infrastructure construction projects in the African continent. To some extent, this involvement of China in cooperation projects has contributed to the improvement of the economic and social conditions of African countries. Given this scenario, it is worth

\footnotetext{
1 The translation of this article was funded by national funds through FCT - Fundação para a Ciência e a Tecnologia - as part of OBSERVARE project with the reference UID/CPO/04155/2019, with the aim of publishing Janus.net. Text translated by Cláudia Tavares.

2 They are analysed on the following pages.
} 
Vol. 10, No. 2 (November 2019-April 2020), pp. 92-109

asking: What distinctive characteristics does Chinese cooperation have that makes it so attractive to African countries? What are the priority areas to which cooperation funds are directed? What interests are seen in infrastructure cooperation projects for African countries, particularly sub-Saharan Africa? And finally, infrastructure works, who really benefits?

In order to answer these questions, we intend to analyse, at first, the characteristics that the cooperation between China and Africa presents, investigating the priority areas around which the cooperation projects are directed and the modality of financing of those projects. In a second moment, we consider the construction of one of the sections of the railway in Kenya (Mombasa-Nairobi project ${ }^{3}$ ) within the framework of the Belt and Road Initiative (hereinafter BRI) as a typical case of China's infrastructure cooperation in an African country.

It is important to note that the academy is divided among those who consider China as an emerging power (Stuenkel, 2018; Ikenberry and Lim, 2017; Xing and Shaw, 2016; Zeng and Breslin, 2016; etc.) and those who claim that it has already become an emerged power in the current international order (Oviedo, 2019; Muñoz, 2019; Borella, 2019). Consequently, it is based on the presumption that as China transforms form "emerging to emerged", its infrastructure projects conceived as part of the conceptual umbrella of South-South Cooperation (CSS) are losing the solidarity character, to form a global strategy that bears similarities with British Pax ${ }^{4}$. In this sense, the cooperation that China makes in the countries of Africa has changed depending on the evolution and deepening of the development model that is going through its economy, characterized by being a fundamentally financial cooperation - expressed in loans (concessional and nonconcessional), foreign direct investment, subsidies, etc.

On the other hand, these infrastructure projects have been framed in the BRI, being erected as a megaproject of interstate connectivity that aims, on the one hand, to stimulate trade and, on the other hand, to boost Chinese productive capacity abroad; objectives backed by large financial capital.

It is worth noting that, for the development of this work, a qualitative methodology using the technique of triangulation of statistical data issued by various international organizations (World Bank, OECD, Infrastructure Consortium for Africa) was applied and by the national governments worked here (Kenya, Exim Bank of China, White Papers de China, African Policy Paper de China). The temporary cut focuses on the period from 2000 to 2017, focusing on the coming to power of Xi Jinping and with it, a more assertive action in Chinese foreign policy. In this regard, it is worth noting two events that illustrate this, such as the launch of the BRI in 2013 and the achievement of the "Forum a Strip and a Route for international cooperation" in 2017.

3 It is important to clarify that in the present work we opted for the definition of Mombasa-Nairobi as a way of designating the railway project, which coincides with that adopted by Kenya. This decision is due to geographical orientation, when going from the coast of the Indian Ocean to the interior of the continent.

4 British Pax refers to the historical period in which the British Empire extended its dominance worldwide, characterized by control of maritime trade and the extension of rail networks in its colonial territories and priority trading partners (such as Argentina). 


\section{Africa in China's foreign policy: a look at the political and economic dimensions}

Since the mid-1990s, the People's Republic of China began a process of intensifying ties maintained with African countries, guided by fundamentally economic interests. In this sense, the attention given to the Chinese presence in African countries from the beginning of the 21st century is directly related to the qualitative leap of this relationship in the world economy, becoming a cause for concern (and criticism) for the interests of traditional powers (Visentini, 2013). However, it should not be forgotten that the extension of its diplomatic relations in the continent is functional to its objective of isolating Taiwan internationally, by imposing its "one China only" policy."

Under this repertoire, the foreign policy of the People's Republic adopted the principle of "towards all directions", which theoretically does not imply differentiation between geographical regions or continents. Likewise, China's speech as a developing country, the foundational basis of its foreign policy, intensified. While in practice the great powers and their regional environment are crucial in the design of the external agenda ${ }^{6}$, Africa has kept some priority (Yun, 2014: 13).

In the new century, the diplomatic activity of the Chinese government towards Africa has been intense and high-level, both bilaterally and multilaterally. In chronological terms it is necessary to mention as a first step the launch of the China-Africa Cooperation Forum (FOCAC) in October $2000^{7}$, initial framework that channelled and gave impetus to the actions of the People's Republic of China. Two legal instruments emanated from that first multilateral meeting, the Beijing Declaration and the Program for Sino-African Cooperation for Economic and Social Development, which became the political axes that guided Chinese intentionality ( $L i$ et al, 2012).

The Beijing Declaration (2000) stated that the forum was a framework for collective dialogue on the pillars of equality and mutual benefit, recognizing themselves as developing countries. In addition, the Five Principles of Peaceful Coexistence were mentioned as well as the principles of the UN and AU Charter. In the attached program, the areas of cooperation were detailed, including: trade and investment; infrastructure projects; financial cooperation; debt relief; tourism; migration; agricultural cooperation; exploration and use of natural resources and energy; cultural cooperation; scientific and technological, public health, education and human resources development; environmental and biodiversity management and arms control. Subsequently, at the second FOCAC ministerial meeting in $2003^{8}$ in Addis Ababa (Ethiopia) a new Action Plan for the period 2004-2006 was adopted, which sought to improve the implementation of the previous documents.

5 This principle of Chinese foreign policy implies that those countries that recognize Taiwan must break diplomatic relations in order to establish them with the People's Republic of China.

6 For illustration, China's main trading partners in the world are the United States, the European Union, the Association of Southeast Asian Nations (ASEAN), Japan and Hong Kong (Information taken from https://oec.world/en/profile/country/chn/ - Consulted on 27-09-2019).

7 The first ministerial summit was held in Beijing and was attended by 44 ministries of African countries (ministries of foreign affairs and trade) and officials from 80 Chinese ministries. The first leaders of Togo, Algeria, Zambia, Tanzania and the Secretary General of the African Union also attended. Information extracted from Ministry of Affairs, China https://www.fmprc.gov.cn/zflt/eng/gylt/dyjbzhy/t157577.htm [Consulted on 05-09-2018].

8 On this occasion, 44 African countries participated again. 
The actions mentioned in the previous paragraph are important as they were the guide of Chinese actions towards African countries until 2006, the year in which the first policy paper on Africa was published. That report and the holding of the third ministerial conference of FOCAC ${ }^{9}$ led to classify it as the "Year of Africa" for China. With this, the continuity granted to the treatment of the African theme can be observed. Also, in 2010 a White paper entitled "China-Africa Economic and Commercial Cooperation" was released, which was followed by a second edition in 2013, already under the change of administration in the hands of Xi Jinping. On the other hand, between 2003 and 2014, two other White papers were issued on "Chinese foreign aid" in 2011 and 2014 respectively, where the privileged place of African countries was explained in Beijing's South-South cooperation policy (detailed below).

The transfer of the government of $\mathrm{Hu}$ Jintao to $\mathrm{Xi}$ Jinping kept the Chinese policy for Africa unchanged. For $\mathrm{Xi}$, the consolidation of friendship with African countries reinforces the Chinese identity of a developing country and its goal in achieving the democratization of international relations and a new international order (Yun, 2014: 13). In 2015, the second policy paper on the Chinese position in Africa came to light, repeating the principles and areas of cooperation established in 2000. It only innovated by boosting the category of comprehensive strategic partnership between the actors involved (The People's Republic of China, China's second Africa policy paper, 2015).

In this regard, Beijing has a hierarchical gradation by which, as ties intensify, the relationship is scaled to a greater position. In this sense, the links start from the lowest gradation to the highest. Comprehensive strategic partnership, then, is the highest condition that a relationship can achieve (Malena, 2015). However, the Asian country has also deepened the link with certain African countries officially ${ }^{10}$.

As for the commercial exchange, China advanced steadily from 2000 onwards, consolidating itself as the main trading partner of the continent in 2009 (The People's Republic of China, 2013). More specifically, in 2013 China became the first export destination of the Sub-Saharan Africa region, surpassing the European Union and the United States - traditional partners of African countries - who went on to take second and third place (Pigato and Tang, 2015: 6). In 2017, the total China-Africa trade volume reached 139 billion dollars (World Integrated Trade Solution, World Bank online). The main destinations for Chinese goods were South Africa and Nigeria, while the largest exporters were Angola, South Africa and Sudan (China Africa Research Initiative online; MOFCOM, The People's Republic of China online).

When analysing the composition of trade, it is observed that it is based on the import of raw materials from African countries and the export of high value-added products. China's imports from sub-Saharan Africa are concentrated in extractive resources such as the crude oil that tops the list. Simultaneously, the People's Republic exported to this region a most diversified production. The highest percentage was met by capital goods (machinery, transport equipment), followed by textiles. The transition to the purchase of

9 As of the third ministerial conference of the FOCAC, the action plans included specific actions rather than a score of intentions. That is why, from 2006 onwards they will be worked on in chapter VI, corresponding to cooperation.

10 Beijing has signed, then, "Comprehensive strategic cooperative partnership" with the Republic of Congo; "Comprehensive strategic partnership" with South Africa, Algeria and Egypt; "Strategic partnership" with Nigeria, Angola, Sudan and the African Union; "Comprehensive cooperative partnership", With Ethiopia, Gabon and Tanzania and finally, "Long term friendship and cooperative partnership", with Senegal (Li and Ye, 2019). 
Vol. 10, No. 2 (November 2019-April 2020), pp. 92-109 China's cooperation in Africa in the area of physical connectivity infrastructure. The case of the Mombasa-Nairobi railway line María Noel Dussort, Agustina Marchetti

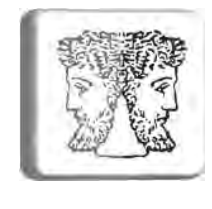

this type of products - which previously came from the United States or the European Union - is because they are more accessible in terms of costs, making them more attractive.

China's Foreign Direct Investment (FDI) in Africa has increased substantially since 2003, reaching a peak in 2008 , then declining as a result of the international financial crisis. FDI is distributed in all sectors of the economy, within which infrastructure has been increasing exponentially. Regarding sector distribution, although Chinese capitals have varied destinations, the extractive industries were the predominant ones at first, exceeding $30 \%$ of the total, followed by construction and the financial and manufacturing sectors (The People's Republic of China, 2010 and 2013; Pigato and Tang, 2015: 11).

FDI in the Asian country has grown from 1.000 million dollars since 2004 to 35.000 million in 2015, representing an average annual growth rate of $40 \%$ (Sun et al., 2017: 20). In the region, the main recipient countries have been Angola, Kenya, Congo (DRC), South Africa and Zambia. In 2017, Chinese investment in Africa reached 4,100 million dollars, which meant a year-on-year increase of $70.8 \%$ but representing only $2.6 \%$ of China's total FDI flows in the world. That said and considering that Asia accounted for $69.5 \%$, Europe $11.7 \%$ and Latin America $8.9 \%$, there should not be an overvaluation of the place that Africa occupies in the distribution of FDI from China at the level global (Ministry of Commerce, The People's Republic of China, 2017: 96).

Beijing has a battery of government tools to deploy its economic interests in the countries of Africa, many of which were specified or proposed in the framework of the China-Africa Cooperation Forum (FOCAC). Among them, bilateral investment treaties with 32 African countries, zero tariff agreements on some exports with the Least Developed Countries and debt relief. Second, in 2006 and as part of one of the commitments established in the FOCAC, the China-Africa Development Fund was inaugurated, created by Chinese financial organizations to provide special support to national companies interested in investing in Africa. Finally, it is interesting to announce that China has promoted the installation of "special economic zones" in African territory - formulating the experience in its own country - in which Chinese companies take over the infrastructure. Finally, it is important to mention the Chinese financial institutions from which most of the loans emanate: China Development Bank, Export-Import Bank of China, Industrial and Commercial Bank of China, Bank of China and China Construction Bank (The People's Republic of China, 2010 y 2013).

In other words, China has been deploying a multidimensional strategy in Africa in the 21st century. Here is noted, in particular, the type of cooperation that Beijing directed to African countries in order to demonstrate the crucial interest it has had in the development of infrastructure works.

\section{China's cooperation in Africa: large infrastructure works at the centre of the scene}

The character of the Chinese CSS evolved along with its own internal dynamics and based on its external insertion needs. The political objective of strengthening and developing friendly cooperation with all developing countries, including especially African countries, has been an important component of China's foreign policy for long (Shelton, 2006). To understand the CSS of China in the 21st century, it becomes necessary to take a brief 
tour to the recent past of the link established with Africa.

Specifically, at the dawn of the People's Republic, solidarity action responded to the need to obtain recognition from the international community as the legitimate government of all of China, and in turn, it was an ideological tool to internationalize communism in the world. So much so that this country began transferring grain, cotton or industrial materials to countries of the socialist orbit (North Korea and North Vietnam) in 1950. That is why the conception of Chinese cooperation arose closely linked to the relationship that the Asian country had with Third World countries, mainly with Africans.

The 1955 Bandung Conference - an event that marked the emergence of the countries of the South in a rigid bipolar order - and the Principles of Peaceful Coexistence ${ }^{11}$ that emanated from it, helped to inform and give confidence to the relations that Beijing was trying to establish with those Afro-Asian nations. Taking advantage of the spirit of Bandung that gave impetus to the first links of communist China with African countries, Prime Minister Zhou Enlai in 1963 enunciated in Sub-Saharan Africa "The Eight Principles for Economic Aid and Technical Cooperation for other countries", which have guided Chinese cooperation to the present. In other words, "the philosophy of Chinese aid" can be summed up in four keywords: self-sufficiency, non-interference, infrastructure works and mutual benefit (Shimomura and Ohashi, 2013: 220). The most striking example that has transcended relations between China and the African countries was the construction of the railway between Tanzania and Zambia (TAZARA) during 1967 and $1975^{12}$.

Given the period of introspection that China started going through in the eighties due to the process of economic reforms implemented by Deng Xiaoping, the motivation to maintain or increase the CSS decreased. The following decade is known as the return of China to the countries of the Global South as part of its international reintegration strategy post Tiananmen massacre, a return enthroned by Jiang Zemin's visit in 1996 to six African countries ${ }^{13}$ where the principles of Sino-African cooperation were highlighted again, guidelines that would lay the foundations of the China-Africa Cooperation Forum (FOCAC) established in the year 2000, as previously mentioned.

During the first decade of the 21st century, there was a resurgence of the CSS that was due to the new impulse granted by emerging powers such as China. According to the analysis of the two White papers on Chinese foreign aid, from 2011 and 2014 respectively, a series of issues related to our analysis theme emerge.

In semantic terms, the 2011 document emphasizes the category of "Chinese foreign aid" as a concept that synthesizes the different forms of cooperation carried out by the Asian country; which is why it can be considered that there is no longer such a resounding rejection of the word "help" (aid) in government circles (Grimm et al, 2011: 4). Such rejection was due to the fact that developed countries had appropriated the concept

11 The five principles of "mutual respect for sovereignty and territorial integrity, mutual non-aggression, noninterference in the internal affairs of other countries, equality and mutual benefit and peaceful coexistence" were brought to the conference by China and India. It is worth mentioning that although a proposal of ten principles emanated from the Bandung Conference, the Five Principles of Peaceful Coexistence are those recognized by China as the cornerstone of its foreign policy. Information taken from the website of the Embassy of the People's Republic of China in Costa Rica http://cr.chineseembassy.org/esp/xwdt/t1173044.htm [Consulted on 31-03-2019].

12 The case of TAZARA is discussed in more detail in the following pages.

13 Kenya, Egypt, Ethiopia, Mali, Namibia and Zimbabwe. Information taken from the website of the Ministry of Foreign Affairs of the People's Republic of China http://www.fmprc.gov.cn/mfa eng/ziliao 665539/3602 665543/3604 665547/t18001.shtml [Consulted on 24-03-2019]. 


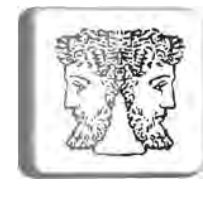

Official Development Assistance (ODA). According to the excerpt: "As development remains an arduous and long-standing task, China's foreign aid falls into the category of South-South cooperation and is mutual help between developing countries" (The People's Republic of China, 2011: 3). From then on, the foreign aid provided by Beijing entered into the CSS category, as an umbrella and generic concept that would contemplate various forms of cooperation among developing countries. Likewise, there was a crucial difference between the first and the second White Paper: while the former referred to the "foreign aid", the second is positioned in the term "foreign assistance", restricting the term "aid" only when it is linked to "humanitarian aid" (emergency humanitarian aid) (Lechini and Dussort, 2016).

Regarding the modalities acquired by the cooperation offered ${ }^{14}$, since 2000 , the most commonly used have been the so-called "complete projects", destined mainly to the sectors of economic infrastructure (transport, electrical energy and telecommunications), industrial and energy (petroleum, metallurgical and coal production industry). By the way, the second White paper clarified that while $72.4 \%$ of the funds between 2010 and 2013 were absorbed by infrastructure projects, $5.8 \%$ were directed to technical cooperation and cooperation for human resources development (The People's Republic of China, 2011 and 2014).

Regarding the institutional architecture in charge of international cooperation, historically the general direction of development assistance policy depended on the Chinese Communist Party Leading Grouping for Foreign Affairs. The latter and the State Council [State Council Leading Group for Foreign Affairs] are the highest level administrative bodies that regulated the agencies responsible for administering cooperation projects: MOFCOM (which had an Aid department for foreign countries); the Ministry of Foreign Affairs (MFA); a series of specialized ministries (Ministry of Science and Technology, Ministry of Agriculture, Ministry of Education, Ministry of Health and Ministry of Communications) and the International Liaison Office of the Central Committee of the Communist Party (Chin and Frolic, 2007).

According to Huang and Wei (2015), the Ministry of Foreign Affairs and the Ministry of Finance had the greatest influence on the foreign assistance policy. But the Ministry of Commerce was the most important government agency in the execution of Chinese assistance since 2003. While the Ministry of Finance established the budgetary funds for aid programs, the Ministry of Commerce was responsible for analysing their viability, coordinating the process of their implementation through the ministries and carrying out their review. From the beginning, the Ministry of Commerce nucleated the total administration of the financial funds. With the creation of EXIM Bank in 1994, this institution began managing soft loans and the Ministry of Commerce to manage subsidies and tax-free loans. The Chinese Development Bank, also founded in 1994, provided financial support to the investments of Chinese companies in developing countries. By positioning external aid within MOFCOM, the strong economic motivation behind each project awarded is demonstrated.

Recently, there was an intense academic debate in China in order to provide institutional alternatives that nucleate cooperation programs. Finally, in 2018 the Xi Jinping

14 From the beginning, they were classified in technical cooperation, human resources training, aid for humanitarian emergencies, complete projects, materials and goods, medical equipment, volunteer programs and debt forgiveness. The first three are supported by subsidies, that is, no payment is expected in return from receiving countries (Mthembu, 2018). 


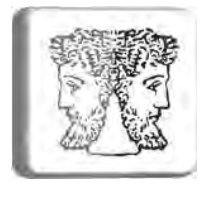

government inaugurated the Chinese Agency for International Development Cooperation (CIDCA) (Huang and Wei, 2015).

Due to the above, it can be understood that historically the financial resources that have sustained the Chinese SSC have been divided into three types: subsidies (financial extension without repayment agreement by the beneficiary), loans at zero interest rate (with a term of 20 years) and soft loans (with a term of 15-20 years and an annual interest rate of $2-3 \%$ ). The fact that from 2000 onwards the soft credits have increased, and the subsidies decreased, also sees the intent of Chinese cooperation.

In geographical terms, the largest recipients of external aid have been the countries of Africa and Asia, and to a lesser extent, Latin America and the Caribbean, Oceania and Eastern Europe. However, since 2010 Africa has accounted for $50 \%$ of all aid (The People's Republic of China, 2011 and 2014).

Simultaneously, it is interesting to compare the above with the analysis made on the state of infrastructure situation in Africa of other international organizations and think tanks (Foster et al, 2009; Gutman et al, 2015; The Infrastructure Consortium for Africa ${ }^{15}$ -ICA-, 2017). According to the 2009 World Bank report (Foster et al, 2009), it was announced that between 2000-2007 the two sectors mostly benefited by Chinese capitals were energy, gathering 33.4\% (particularly hydroelectric power) and transport, with $33.2 \%$ (especially railways). Beijing's financing commitments remained at an average of 5.000 million dollars between those years, focusing on $70 \%$ in Nigeria, Angola, Ethiopia and Sudan. However, from 2007 to 2012 a certain change in the destiny of Chinese financing was demonstrated, from countries rich in strategic natural resources - such as the four previously indicated - to countries that are not. Such is the case that Ghana and Ethiopia were the largest recipients, followed by Cameroon, Zambia and Nigeria (Gutman et al., 2015).

Based on the latest ICA report (2017: 16), Chinese investment commitments in infrastructure works in Africa peaked in 2013, demonstrating that the Asian country collected the highest percentage of financing for the continent (66\% of the total), surpassing international financial organizations and traditional powers. Within this framework, the almost 4 billion dollars allocated to the Mombasa-Nairobi railway section in Kenya were included, the case study that will be addressed below. It should also be mentioned that the amounts for the analysed sector continued in crescendo, reaching a value close to 20,000 million dollars in 2017.

In short, of what transpired in the preceding pages, we can say that China's cooperation was born and developed simultaneously with the relations that the People's Republic maintained with the developing countries, mainly African. Although initially such an action was aimed at spreading the Maoist revolution in the Third World, it was transformed as domestic changes occurred in that country. In this way, Beijing (and its state-owned companies as executing arms), has become the promoter, financier and executor of many of the infrastructure projects that African countries need today.

Departing from the assumption of Xi Jinping in 2012, signs of a global foreign policy are being given, following the launch of initiatives such as the BRI, which gave a central role

15 The ICA is made up of multilateral development banks and regional development banks such as the African Development Bank (AfDB), the South African Development Bank (DBSA), the European Commission, the European Investment Bank (EIB), the countries that make up the G8, the Republic of South Africa and the World Bank Group. 
to interconnectivity and with it, the extension of the works for that purpose. In the following pages, the inclusion of the African continent in the initiative and, in this context, the intensification of the role of China as a state supplier of public goods. Likewise, progress is being made on the Mombasa-Nairobi project, in an attempt to delve into the cost / benefit binomial of Chinese development cooperation in Kenya.

\section{Interconnectivity, focus of the Belt and Road Initiative}

In 2013, Chinese President Xi Jinping during his visit to Kazakhstan announced the economic belt of the Silk Road ("The One Belt"). The same year and in similar circumstances in Indonesia he announced the Maritime Silk Road ("One Road"). Both form what was initially known as the initiative "One Belt, One Road" (OBOR), which is currently defined as "Belt and Road Initiative". The economic belt of the Silk Road aims to link China with Europe through Central Asia and Russia; with the Middle East through Central Asia and unite China and Southeast Asia, southern Asia and the Indian Ocean. On the other hand, the Maritime Silk Road focuses on the use of Chinese coastal ports to link China with Europe through the South China Sea and the Indian Ocean. Africa enters the scene on the sea route. Although, initially, their participation in official terms was not entirely clear, in fact some African countries are part of the initiative. However, "only African countries considered strategic for OBOR, especially those vital to establish and secure commercial links, would be prioritized by the Chinese government" (Bagwandeen, 2017: 2).

The BRI stands as one of the most ambitious and important programs of the 21st century, which aims to achieve an integrated economic architecture (Concatti, 2017). Therefore, it is fundamental for the Chinese government to improve physical connectivity between the countries involved as a first step. Consequently, a succession of projects aimed at narrowing the "infrastructure gap has already been launched.".

With China's global strategy in mind, numerous projects focused on transport infrastructure were initiated in several African states with the backing of Beijing. In 2009, the East Africa Railway Master Plan Study (EARMP) was published, in which a report on the status of the railroads in East Africa was made. EARMP issued a proposal to optimize their use and increase the volume of tons transported, projecting an increase from 3,700 million in 2007 to 16 million in 2030 (CPCS, 2009). In the updated version of that report, published by the East Africa Community (EAC) In 2017, the Asian country appeared as the key actor in the completion of the railway master project.

Beijing promised to lead the formation of Chinese group for Sino-Africa cooperation in railway and high-speed railway ${ }^{16}$ in that region of Africa, which would integrate resources from financing institutions, railway construction companies and railway operations management companies. In this way, it can be seen that the Asian giant has been advancing steadily in the railway sector of the region ${ }^{17}$.

16 For more information see press report of the African Union. Available at: https://au.int/en/pressreleases/20161010-2

17 At the continental level, progress was made in infrastructure cooperation through the Memorandum of Understanding between China and the African Union signed on January 25, 2015, which consolidated China's plans for Africa with the aim of promoting railroad cooperation, roads, regional aviation networks and industrialization fields. On October 5, 2016, a Five-Year Action Plan was signed at the UA headquarters, between the African Union Commission (AUC) whose presidency was in charge of Dr. Nkosazana Dlamini 
Four years after the launching of the initiative, China convened the first Belt and Road Forum for international cooperation -Belt and Road Forum (BRF)- in May 2017 in Beijing, under the motto "Work Together to Build the Silk Road Economic Belt and The 21st Century Maritime Silk Road", in which government representatives from more than one hundred countries participated. In the opening address, President Xi Jinping emphasized that the initiative is based on the principles of peaceful cooperation, openness and inclusion, learning and mutual benefits. He also stressed that there are four major priority areas of cooperation, all crossed by the principle of "interconnectivity": infrastructure, commerce, finance and contact between people (people to people connectivity). In this regard, it is highlighted that the initiative strives to increase cooperation and exchange in fields such as technology, natural resources, tourism, environmental protection and NGOs. Within the infrastructure cooperation, the emphasis was on railroads, roads, air routes, telecommunications, pipelines and gas pipelines and ports (XinhuaNet, 2017).

From the African continent, four countries participated in the event, namely: Egypt, Tunisia, Ethiopia and Kenya (The Diplomat, 2017). It is no accident that two of them are part of the East African region, with its shores in the Indian Ocean, becoming key places in the Chinese initiative. In fact, the port of Nairobi is marked on the maps that show the route of the sea route ${ }^{18}$.

As mentioned in previous paragraphs, initially African participation in the BRI appeared with a question mark. However, at present, the interest and impulse of African countries to extend it to their territories can be affirmed. Such is the case, that some authors already classify it as "a second belt" (Breuer, 2017). The truth is that in the framework of the 2018 FOCAC summit in Johannesburg, China included the BRI at the conclusion of the signing of memoranda of understanding (MoUs) bilaterally with thirty-seven African countries and the African Union ${ }^{19}$, where they expressed the political will for the joint development of the initiative (Xinhuanet, 2018). It should be noted that Kenya is among the signatory countries (Mbogo, 2018), reaffirming the geostrategic relevance it has for its spatial location.

\subsection{Kenya, another gateway to Africa: the Mombasa-Nairobi railway}

As it became known, China's participation in railway infrastructure projects in Africa dates back to last century. It is necessary to remember that already in the sixties Beijing was the key player in the construction of the TAZARA ${ }^{20}$, binational railroad jointly owned by

Zuma and the representative of the government of the People's Republic of China, Mr. Xu Shaoshi, Minister of National Development and Reform Commission (NDRC). Within the framework of the Action Plan several milestones were proposed to be developed during the period in question, such as: the agreement on relevant laws and regulations on railway cooperation; the establishment of a Project Implementation Unit (PEU) by the AUC; collaboration and simplification between African and Chinese companies; technology transfer, education and capacity building for manufacturing locally-owned goods (African Union, 2016).

18 See maps of the following sites: Xinhua; World Economic Forum; The Economist, Kenyan Wall street.

19 According to Belt and Road Investment Index Report 2018, prepared by the Shangai Municipal Commission of Commerce, the countries that are part of the initiative are South Africa, Kenya, Morocco, Ghana, Tanzania, Nigeria, Ethiopia, Egypt, Madagascar, Algeria, Tunisia, Sudan, Congo and Angola. Anyway, it is important to consider that all the projects previously agreed between an African government and China -after signing the MoUs for which they have been called "BRI countries" - have been incorporated into the initiative.

20 In the sixties, the governments of Tanzania and Zambia were working on the design, but they knew that this gigantic project required large amounts of funds to take off. At first, they contacted Western countries to get help to build the line, but those rejected the idea and insisted that "the project was not economically viable". It was there that the government of the People's Republic of China, under the direction of Mao quickly accepted and offered to finance it as a turnkey project. It was then that on September 5, 1967, an 
Vol. 10, No. 2 (November 2019-April 2020), pp. 92-109 China's cooperation in Africa in the area of physical connectivity infrastructure. The case of the Mombasa-Nairobi railway line María Noel Dussort, Agustina Marchetti

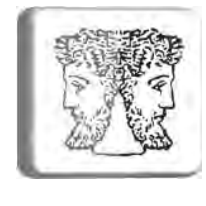

the governments of the United Republic of Tanzania and the Republic of Zambia. In terms of interconnectivity, TAZARA linked Zambia with the seaport of Dar es Salaam in Tanzania and provided roads and railways. In essence, it was a backbone communication network for the East African Community. This project has become a symbol of China's solidarity cooperation in Africa, which persists to the present. It realizes that in July 2018, a meeting was held between the Minister of the Central Committee of the International Department of the Communist Party of China (PCCh), Mr. Song Tao, and the authorities of TAZARA, to whom he has requested the advancement of the "Spirit of TAZARA" as a symbol of friendship, committing himself to the modernization of it (TAZARA, 2018) ${ }^{21}$.

In this context, China and the African Union signed a MoU in 2015 with the objective of connecting their capitals and important cities with an integrated high-speed rail network, an emblematic project of the 2063 Africa Continental Agenda. Meanwhile, the Chinese project of modernization and railway construction of the Mombasa-Nairobi section in Kenya is also part of the East African Railway Master Plan - which aims to extend throughout Tanzania, Kenya, Uganda, Rwanda, Burundi, South Sudan and Ethiopia.

The case of the Mombasa-Nairobi (or Madaraka Express) railway section is of particular interest since it runs parallel to the Uganda Railway (known as "Lunatic Express"), built by Great Britain at the end of the 19th century, when these territories were under British rule (Duell, 2017). The lack of maintenance of these communication channels generated a significant deterioration in transport capacity 22 .

Consequently, the SGR project, funded mostly by China, was designed in two large corridors: Northern corridor and Lapsset corridor ${ }^{23}$, which cover different sections of the railway. The Northern Corridor It consists of two phases: the first of $472 \mathrm{~km}$ from Mombasa to Nairobi, which is completed and was inaugurated on May 31, 2017. The second phase, of $490 \mathrm{~km}$ total completing the Nairobi - Kisumu - Malaba route, is in turn made up of 3 subphases of which only the first one is underway.

The main actors involved in the design, construction and execution of the MombasaNairobi section were mainly two large Chinese companies. On the one hand, the China Road and Bridge Corporation (CRBC) ${ }^{24}$ which was hired by Kenya Railways (KR) to carry out the first phase of the Northern Corridor and also two commercial contracts were signed, namely: one related to the construction of civil works under the turnkey modality and another for the supply, purchase and installation of locomotives and rolling stock. On the other hand, KR and China Communications Construction Company (CCCC) have signed four commercial contracts for the development and execution of the second phase

agreement was concluded for the construction of TAZARA in Beijing, between the governments of China, Tanzania and Zambia. The Chinese financed the project, provided support for construction, experience and equipment, including buildings, workshops, training schools and related infrastructure. The initial idea was for the rail line to start from Kidatu in Tanzania to Kampoyo in Zambia. In 1970, China agreed to grant Tanzania and Zambia an interest-free loan repayable in thirty for a total of 988 million yuan- to cover the costs of construction of the line and the supporting infrastructure of the stations and the training school, as well as the supply of motor energy and rolling stock.

21 For more information about this project you can read: "Freedom Railway. The unexpected successes of a Cold War development Project". Available: http://bostonreview.net/jamie-monson-freedom-railway-tazaratanzania

22 The Uganda Railway is a railway that connects Lake Victoria to the port of Mombasa. In the eighties its transport capacity was 4.8 million tons and in 20121.5 million (Mugwe, 2018).

23 For more information about this corridor visit: http://www.lapsset.go.ke/projects/railway/. It consists of two large sections: the first Lamu - Isiolo - Nakdok that will cover 1,350 km; and the second Nairobi - Isiolo - Moyale over $700 \mathrm{~km}$.

24 It is a subsidiary of the China Communications Construction Company (CCCC). 
Vol. 10, No. 2 (November 2019-April 2020), pp. 92-109

of the Nairobi-Malaba section of the project. With regard to construction supervision, it is the responsibility of the China Railway Development Company, Apec Consortium Limited and Edon Consultants International (CRDC/APEC/EDON Consortium) who are responsible for the review and supervision of design and construction to ensure that quality standards are met.

The cost of the first phase Mombasa-Nairobi amounted to 3,223 million dollars, which made it the most expensive infrastructure projected in Kenya since its independence and equivalent to $20 \%$ of its national budget (Changfeng \& Ziro Mwatela, 2016). The financing was provided by $90 \%$ of the Exim Bank of China through the granting of a loan to the Kenyan government. The remaining $10 \%$ was financed by the African country who did so through a Railroad Development Fund, anchored in a 1.5\% tax on the cost of overseas imports transported in Madaraka Express (Kenya Railways, 2019; Railway Gazzette, 2017).

To summarize we can see that according to the above detailed, China is concerned not only with the financing, construction and execution, but also with the provision of materials and project supervision. What can be seen is that the Madaraka Express meant advances and improvements reflected, on the one hand, in the increase in volumes transported to and from the port; and on the other hand, the reduction of costs and travel time, the promotion of investments and an improvement in the competitiveness of markets.

To account for this, the National Statistics Office of Kenya (KNBS) reported that the rail service transported 699,055 passengers between June and December 2017, a number that increased to just over 1.5 million in 2018. In addition, the SGR freight service transported 5 million tons of merchandise in 2018, with a total revenue of 863,177 million dollars (Xinhua News Agency, 2019). Regarding the reduction of transport time, while the "Lunatic Express" takes about 12 hours to make Mombasa-Nairobi, the Madaraka Express completes the section between 4 and 5 hours. As far as employment is concerned, the project has created at least 19,400 direct jobs and 6,000 employees by subcontractors (Breuer, 2017).

Once the project is fully completed, further decongestion in the Port of Mombasa and an exponential increase in cargo volumes transported to and from the port are expected. Another advantage will be reflected in the even greater decrease in production costs, making the region a competitive and attractive destination for foreign investments that will help in the export of various resources stranded in the region. Finally, it is argued that road wear will be reduced, so maintenance costs will also be reduced (Kenya Railways, 2019).

However, despite the great contribution that the railway project has achieved, there are also two major challenges that the Kenyan government must face as a side effect of its realization. First, as of 2013, the trade balance deficit between Kenya and the Asian country deepened, amounting to 3,681 million dollars in 2017. This is due to the substantial increase in imports of Kenya from China equivalent to 5,000 million dollars mostly of consumer, capital and intermediate goods. (World Integrated Trade solution, World Bank, 2019).

Second, the environmental issue is another of the problematic axes of the project. Although the first section crossed "Tsavo National Park", bridges, underground passages and pens were built to provide the animals with alternative passageways. However, the 
second phase was stopped because the project implied that it crossed the "Nairobi National Park", to which were opposed self-proclaimed conservation sectors of the society (Breuer, 2017). In order to overcome this obstacle, the government undertook to reduce the carbon footprint of the trains involved in the project in order to reduce the environmental degradation of its territory (Kenya Railways, 2019).

In summary, from the above, we can affirm that although the railway project is a work that contributes in the short and medium term to the growth of Kenya, its government must face an ever deeper external debt, with China being the main creditor accounting for $66 \%$ (Anzetse Were, 2018). In the same way, a viable path to deal with the debt with the People's Republic cannot be observed in the near future. So much so, that Kenya had to borrow from third countries (such as Japan, France, Germany, etc.) in order to support it. In other words, the African country is trapped in a vicious circle that assimilates a new dependence, but with Chinese characteristics, known as 'debt trap'.

\section{Conclusions}

After having approached infrastructure cooperation in Africa, particularly the case of the Mombasa-Nairobi project, it has allowed us to make the following final reflections. First, it is important to highlight that the CSS was always present as China's foreign policy tool in the approach to developing countries. Moreover, infrastructure cooperation has emerged as a symbol of development cooperation, mainly towards African countries. It is true that the first example that illustrates such a commitment was the TAZARA, at a historic moment when the Asian country was not the economic power that it has become today. Therefore, beyond the political and ideological interests that went through the realization of such a project in East Africa, it was a solidarity action per se.

However, as China consolidates its internal development model, its foreign policy interests have changed to the extent of its rise in the international order. In this sense, infrastructure cooperation projects are not only of vital importance to stimulate development in African countries, as the Asian giant affirms, but mainly to promote commercial exchange and expand the activities of its state-owned companies. Precisely, the launch of the BRI in 2013 responds to Beijing's global strategy and it is no less than its nerve centre is the construction of civil-type infrastructure works.

Within the framework of the BRI, the efforts of the African countries to incorporate their continent in this initiative should be highlighted. The fact of being part of a strategy that involves half of the globe and that has prospects of becoming global, gives Africa a position of unenforceable geopolitical relevance. However, African countries also compete with each other for more benefits in their relations with China. In this regard, Kenya is perceived and perceives itself as another point of entry (or exit, depending on the point of view) to Sub-Saharan Africa, in addition to the states grouped under this characteristic, namely South Africa or Nigeria. The Mombasa-Nairobi railroad project has granted Kenya a privileged position, because it postulates Mombasa to become the main port of East Africa, in addition to becoming a modern transit route from the Indian Ocean to central Africa.

Lastly, it is interesting to evaluate whether the above-mentioned infrastructure cooperation project effectively allows for a mutually beneficial relationship. As for China, as stated, the gains are evident. On the contrary, for Kenya, from a first approach, the 
project would be very beneficial, although, it is necessary to examine some effects in the short and medium term. Regarding the "pros", this type of works reduces production costs indirectly, by reducing the cost of freight. Consequently, it would increase the competitiveness of Kenyan exports (and those of neighbouring countries) as well as Nairobi would improve tax collection by exploiting this new communication channel.

However, as noted, Kenya's way of paying the Chinese Exim Bank loan is through a lien on the use of the railroad. In addition, while the project is being carried out, China is the one who decides on all phases of implementation. That is, the African country does not have autonomy on the matter in any way. At the same time, Kenya's balance of payments has deteriorated since project implementation, becoming highly deficient. This is because China imports the machinery, goods and services it needs for project execution. Which leads us to affirm that in a short period of four years (2013-2017) Nairobi's economy became very dependent on the relations with Beijing.

It is clear that China gives countries such as Africans the possibility of accessing tangible, necessary, rapid investments without the bureaucracy characteristic of international financial organizations. However, projects that are framed as CSS have many similarities with the attached help (better known as "tied aid") practiced by the traditional powers, when certain conditionalities are established that end up blurring the advocated solidarity horizon.

All of the above leads to reinforcing the idea that China is intensifying its role as a state supplier of world public goods. So, this "hegemon aspirant" seems to be emulating certain characteristics of British Pax on the way to the establishment of its own China Pax.

\section{References}

Africana, U. (2016). Unión Africana. [En línea] Available at: https://au.int/en/pressreleases/20161010-2

Aldekoa, X. (2017). "Un tren chino para la nueva África". In La Vanguardia Internacional, 1 junio.

Anzetse, Were. (2018). "Debt Trap? Chinese Loans and África's development options". In South African Institute of International Affairs. Policy InsightS 66:1-12.

Bagwandeen M. (2017). The African Link in China's OBOR Initiative, Stellenbosch, Sudafrica: Centre for Chinese Studies.

Banco Mundial (2019). Kenya Country Profile [En línea] Available at: http://databank.worldbank.org/data/views/reports/reportwidget.aspx?Report_Name $=\mathrm{C}$ ountryProfile\&Id=b450fd57\&tbar=y\&dd=y\&inf $=n \& z m=n \&$ country $=$ KEN

Borella, G. (2019). "La otra hegemonía global. China aspira al liderazgo tecnológico". In La Nación, 24 marzo.

Brautigam, D. (2009). The Dragon's gift. The real story of China in Africa. London: Oxford University Press.

Breuer, J. (2017). "Two belts, one road? The role of Africa in China's Belt and Road Initiative". In Blickwechsel, pp. 1-7.

C. P. C. S. (2009). East African Railways Master Plan Study Final Report, Bridgetown, 
Barbados: CPCS Transcom.

Changfeng \& ZiroMwatela. (2016). "Africa in China's'One Belt, One Road'Initiative: A Critical Analysis". OSR Journal Of Humanities And Social Science (IOSR-JHSS),21(12), pp. 10-21.

Chin, G. T.; Frolic, B. M. (2007). "Emerging Donors in International Development Assistance: The China Case". In The International Development Research Centre (IDRCCDRI), Ottawa.

China Africa Research Initiative. [En línea] Available at: http://www.sais-cari.org/

Concatti, B. (2017). "Los desafíos de la Nueva Ruta de la Seda para India". In Journal de Ciencias Sociales, 5(9), pp. 178-187.

Denghua, Z. (2014). "China's second White Paper on foreign aid". In The State, Society \& Governance in Melanesia Program (SSGM).

Duell, M. (2017). "Kenya FINALLY replaces the 'Lunatic Line' built by the British more than a century ago where workers faced the perils of hungry lions, malarial swamps and angry tribesmen". In MAIL ONLINE, 31 mayo.

Foster, V., Butterfield, W., Chen, C. \& Pushak, N. (2009). Building bridges China's growing role as infrastructure financier for Sub-Saharan Africa, Washington: World Bank.

Gazzette, R. (2017). "Mombasa - Nairobi Standard Gauge Railway opened". In Railway Gazzette , 31 mayo.

Grimm, S., Rank, R., Mcdonald, M. \& Schickerling, E. (2011). Transparency of Chinese aid. An analysis of the published information on Chinese external financial flows. Stellenbosch: Publish What You Fund; Centre for Chinese Studies.

Gutman, J., Sy, A. \& Chattopadhyay, S. (2015). Financing African infrastructure. Can the world deliver? Washington: Brookings.

Huang, M. \& Wei, X. (2015). "The Chinese foreign aid management system and its reform". In Sidiropoulos, E., Pérez Pineda, J. A., Chaturvedi, S. y Fues, T., Institutional Architecture \& Development. Responses from Emerging Powers, Johannesburg: South African Institute of International Affais (SAIIA).

Ikenberry, G. J. \& Lim, D. J. (2017). China's emerging institutional statecraft. The Asian Infrastructure Investment Bank and the prospects for counter-hegemony. Washington: Brooking.

Johnston, L.A. (2016). "Africa, and China's One Belt, One Road initiative: Why now and what next?". In Bridges Africa, 5(7).

Kenya Railways (2019). Kenya Railways. [En línea] Available at: http://krc.co.ke/?page_id=1382

Lechini, G. \& Dussort, M.N. (2016). "China y la Cooperación Sur-Sur. Una mirada desde Argentina". In Moneta, C. \& Cesarín, S. China y Argentina: la tentación pragmática. Buenos Aires: EDUNTREF. pp.77-112.

Li, A.; Lui, H.; Pan, H., Zeng, A. y He, W. (2012). Focac Twelve Years Later. Achievements, challenges and the Way Forward, Discussion Paper 74, Perking University: [En línea] Available at: https://www.files.ethz.ch/isn/151831/FULLTEXT01-4.pdf 
Vol. 10, No. 2 (November 2019-April 2020), pp. 92-109 China's cooperation in Africa in the area of physical connectivity infrastructure. The case of the Mombasa-Nairobi railway line María Noel Dussort, Agustina Marchetti

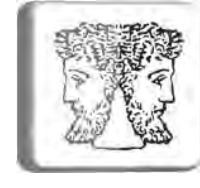

Li, Quan; Ye, Min (2019). "China's Emerging Partnership Network".

Malena, J. (2015). "Análisis del status de 'socio estratégico integral, conferido por la R. P. China a la R. Argentina'", Simposio Electrónico Internacional sobre Política China.

Mbogo, A. (2018). "Kenya Signs Silk Belt \& Road Agreement with China". The Kenian Wall Street, 6 septiembre.

Ministry of Commerce (MOFCOM), The People's Republic of China http://english.mofcom.gov.cn/

Ministry of Commerce, The People's Republic of China (2017). Statistical Bulletin of China's Outward Foreign Direct Investment. National Bureau of Statistics, State Administration of Foreign Exchange.

Mitchell, D. (2007). China and the developing world. The China balance sheet in 2007 and beyond. Washington: Center for Strategic and International Studies.

Mthembu, P. (2018). China and India's Development Cooperation in Africa. The rise of Southern Powers. London: Palgrave Macmillan.

Muñoz, M. (2019). La China del Siglo XXI. Madrid: Coyve SA.

Muwge, D. (2013). "Rail transport makes a comeback". Daily Nation, 19 agosto.

Observatory of Economic Complexity [En línea] Available at: https://oec.world/en/profile/country/chn/

Olguín Vélez, P.M. (2011). "El compromiso de China con el desarrollo del tercer mundo: el caso de Angola". In Estudios de Asia y África, XLVI (3), pp.589-649.

Oviedo E.D. (2019). "América Latina en la mira". In Le monde Diplomatique, febrero, Issue 236, pp. 22-23.

Pigato, M. \& Tang, W. (2015). China and Africa: Expanding Economic Ties in an Evolving Global Context, World Bank. [En línea] Available at: http://www.worldbank.org/content/dam/Worldbank/Event/Africa/Investing\%20in\%20A frica\%20Forum/2015/investing-in-africa-forum-china-and-africa-expanding-economicties-in-an-evolving-global-context.pdf

Sarkar, S. (2017). "China rolls out railways across the continent". In African Bussines Magazine, 11 enero.

Shanghai Municipal Commission of Commerce \& Deloitte. Belt and Road Countries Investment Index Report 2018. [En línea] Available at: https://www2.deloitte.com/content/dam/Deloitte/cn/Documents/ser-soe-br/deloittebri-2018-belt-and-road-countries-investment-index-report-en-190805.pdf

Shaw, T. Xing Li. (2016). "O sonho Chines versus o sonho americanono reordenamento mundial: mesma cama? sonhos distintos?". In J. Vadell, ed. A expansão econômica e geopolítica da China no século XXI. Belo Horizonte: PUC Minas, pp. 43-72.

Shelton, G. (2006). "China, África y Sudáfrica. Avanzando hacia la cooperación Sur-Sur". In Boron, A.A. \& Lechini, G. Política y movimientos sociales en un mundo hegemónico. Lecciones desde África, Asia y América Latina. Buenos Aires: CLACSO. pp.347-84.

Shimomura, Y. \& Ohashi, H. (2013). "Future prospects of China's foreign aid". In Shimomura, Y. \& Ohashi, H. A study of China's foreign aid. An Asian perspective. London: 
Palgrave Macmillan. pp.219-38.

Stuenkel, O. (2018). O mundo pós-Ocidental. Potências emergentes e a nova ordem global. Rio de Janeiro: Zahar.

Sun, I. Y., Jayaram, K., \& Kassiri, O. (2017). Dance of the Lions and Dragons: How are Africa and China engaging, and how will the partnership evolve?. McKinsey \& Company.

TAZARA (2018). TAZARA. [En línea] Available at: https://tazarasite.com/communistparty-china-calls-improvement-tazara

The Diplomat. (2017). Belt and Road Attendees List. s.I.: The Diplomat.

The Infrastructure Consortium for Africa (2017). The infrastructure financing trends in Africa - 2017, Abidjan: The Infrastructure Consortium for Africa; African Development Bank Group.

The People's Republic of China (2006). China's African Policy, Beijing: s.n.

The People's Republic of China (2015). China's second Africa policy paper, Beijing: s.n.

The People's Republic of China, I. O. o. t. S. C. (2011). China's Foreign Aid, Beijing: s.n.

The People's Republic of China, I. O. o. t. S. (2013). China-Africa Economic and Trade Cooperation, Beijing: s.n.

The People's Republic of China, I. O. o. t. S. (2014). China's Foreign Aid, Beijing: s.n.

Visentini, P. F. (2013). África e as Potências Emergentes, Serie Africana, Porto Alegre: Editorial Leitura XXI.

World Bank, World Integrated Trade solution. [En línea] Available at: https://wits.worldbank.org/countrysnapshot/es/KEN

Xi Jinping (2017). Discurso en la ceremonia de apertura del "The Belt and the Road Forum for International cooperation 'Work Together to Build the Silk Road Economic Belt and The 21st Century Maritime Silk Road'". s.I.: XinhuaNet.

Xinhua News Agency. (2019). Belt and Road Portal. [En línea] Available at: https://eng.yidaiyilu.gov.cn/qwyw/rdxw/83313.htm

XinhuaNet (2018). China signs MOUs with 37 African countries, AU on B\&R development. XinhuaNet, 7 septiembre.

Yun, S. (2014). Africa in china's foreign policy, Washington: Brookings.

Zeng, J. \& Breslin, S. (2016). China's 'new type of Great Power relations': a G2 with Chinese characteristics?. International Affairs, Volumen 92, pp. 773-794. 


\title{
THE 3 SEAS INITIATIVE: GEOPOLITICS AND INFRASTRUCTURE
}

\begin{abstract}
Bernardo Calheiros
bernardo.calheiros@gmail.com

Master in Strategy and Under-graduation in International Relations. National Defense Course and Advanced Geopolitics Studies Course. Former Director of Bilateral Relations Services at the Ministry of National Defense (Portugal). Consultant for the companies Gaporsul and Kyron Consultores. He is currently senior technician at the Directorate of International Relations of the General Directorate for National Defense Policy.
\end{abstract}

Abstract

The Three Seas Initiative (I3M) is an ambitious geopolitical project comprising twelve EU Member States located between the Baltic Sea, the Black Sea and the Adriatic Sea: from North to South, a wide range encompassing Estonia, Latvia, Lithuania, Poland, Czech Republic, Slovakia, Hungary, Austria, Romania, Bulgaria, Slovenia and Croatia. It is a region with more than $25 \%$ of the EU's territory and about $22 \%$ of its population, but with a much lower economic representation. I3M aims to promote the development of central European infrastructures with a view to bringing this region closer to the economic development levels of other European countries.

The I3M aimed for development of large projects of regional infrastructure in three major fields: energy, transport (road and rail) and the digital field (communications).

The geopolitical importance of this project is immediately evident from the fact that many of these countries are landlocked states with no access to the sea. These infrastructures will now give them access to three seas and thus contribute to greater independence and room for maneuver in their policies. This region, situated in the center of the European continent, one of the main energy markets of the future, is also the scene of a very strong trade struggle between Russia, with its natural gas supplies, and the US, with its growing production of shale gas.

The projects launched by I3M are therefore of greater economic and geopolitical importance, although they still have to ensure appropriate funding. Although the Three Seas Fund (TSF) was created), with a duration of 30 years and which aims to secure a financing of 100 billion euros (from an initial investment of the Member States in the amount of 5 billion euros), The truth is that much will depend on the support given by the EU and the countries interested in these projects, such as the US and China (link to the silk route).

Some European countries have seen the birth of this Initiative with some suspicion, such as Germany, which has increasingly been focusing on Nordstream II, and Russia, which accuse their promoters of representing US interests on the European continent.

Regardless of the controversies raised, I3M seems to be a form of regional cooperation that makes perfect sense and fully integrates into the spirit of European integration, seeking for its peoples the same development as the other Member States.

\section{Keywords}

Three Seas Initiative, Central Europe, Energy, Infrastructure

\section{How to cite this article}

Calheiros, Bernardo (2019). "The 3 Seas Initiative: Geopolitics and Infrastructure". JANUS.NET e-journal of International Relations, Vol. 10, N.o 2, November 2019-April 2020. Consulted [online] on the date of the last visit, https://doi.org/10.26619/1647-7251.10.2.8 


\section{Bernardo Calheiros}

\section{Introduction}

Gradually, the European Union has been expanding, and increasing the number of its member states. It was also able, in parallel, to launch the single currency - the euro and deepen their degree of integration, even in times of crisis. It was not, however, able to prevent the existence of a multi-speed Europe, generating ideological cleavages and different perceptions of the Union model. Not even able to keep the acquis communautaire intact... and even see its integrity possibly as a large territory, with issues such as Brexit's...

In this process, there are aspects which are crucial for the future of Europe, and especially of Community Europe. First, the definition of its geographical boundaries. The Union has not stopped expanding, including any state that meets the membership criteria, without being careful to clearly define its boundaries. Problems such as those arising from issues such as Turkey's drift, and the Russian Federation-induced fragmentation processes in Ukraine and Georgia thus arise. A geopolitical entity such as the European Union necessarily has to explain its project, its founding idea and what is the space it concerns. A process that, to say the least, seems to be in crisis today.

Enlargement has been fast, but not without tensions, as divisions and regional blocs are emerging between Member States that share common interests and do not see themselves in the Paris-Berlin axis. These divisions are also assuming an ideological feature, with the emergence of alternative proposals, which have even led to attempts to marginalize the countries that propose them. Worse still, some countries are discussing leaving the euro, or even the Union, as is the paradigmatic case of the United Kingdom.

This work focuses specifically on the Central European region - a broad concept of Central Europe, as we will see - and, more specifically, the recent Three Seas Initiative (I3M), which refers to the space between the Baltic, Adriatic and Black Seas and which has been shrouded in some controversy. Central Europe seems to be back, being a region that has common features and problems among its member states, some political identification, a shared past, and the perception of common threats.

The enlargement of the European Communities - and after the European Union - was done, until a certain moment, by integrating countries that had in common the fact that

1 The translation of this article was funded by national funds through FCT - Fundação para a Ciência e a Tecnologia - as part of OBSERVARE project with the reference UID/CPO/04155/2019, with the aim of publishing Janus. net. Text translated by Cláudia Tavares. 
they belonged to the community of democracies in western Europe. It was a set of states, which albeit with different economic developments, had a great homogeneity in political terms and even in recent historical experience, marked by the "security guarantees" given by the Atlantic Alliance, which has enabled them to achieve major economic development based on increasing legal certainty which, although noticeably unevenly, has been establishing there.

With the fall of the Wall and the liberation of the countries of "Eastern Europe", they soon aspired to join the European Union on the one hand, in pursuit of the development they had dreamed of, and on the other hand to NATO, the organization that provided them with such assurances of security and respect for their newly acquired sovereignty.

However, if it is true that most of these countries joined the European Union and the Atlantic Alliance in the early years following the fall of the Wall, it is also true that they were still very suspicious of their eastern neighbor - now the Russian Federation - and also somewhat reluctant to join federalist projects that implied important compromises in terms of national sovereignty. It is therefore not surprising that, in parallel with the process of European integration, if they were drawing up forms of regional cooperation of which the Visegrad Pact is the most visible example - a point we will return to. These did not undermine European integration - far from it - but they emphasized regional specificities, which included not just economic issues (in terms of development, infrastructure needs, energy dependence, etc.), but also political and of security (fear of Russian interventionism, defense of sovereignty, etc.). Their perceptions of security were often not shared by other countries, who did not know what it was like to live under a totalitarian communist regime for almost half a century.

The European Union did not oppose these forms of regional integration and even considered them to have several positive aspects. Thus, these were growing in number and importance, becoming particularly active at the very moment when a President emerged in Russia - Vladimir Putin - who comes to challenge the policies of its predecessors and shelter some revisionist theories that criticized the breakup of the Soviet Union, the loss of territory and NATO's strategic advance towards its borders. Thus, organizations such as the Pact of Visegrad (so-called Visegrad 4, which began with a series of informal meetings to agree positions on their entry into the European Union, and that later has been formalized, recreating itself as a Visegrad Plus, a larger and less formalized entity to include "without identity loss" other adjacent states, such as Georgia) - grouping Poland, the Czech Republic, Slovakia and Hungary -, which had a rather residual activity so far, have strengthened their cooperation and will even arouse the interest of other countries in the region, such as the Baltics and Romania.

While asserting their allegiance to the European Union and the European project, these countries viewed with increasing suspicion the more federalist proposals being put forward by France and other Member States. Their security - this is their belief - is essentially guaranteed by NATO and the United States, with problems that greatly affected the countries of the region and which had economic and security implications, one of the main being energy dependence on Russia. As important a problem as the Kremlin was proven to use it as a geopolitical weapon, as it became evident in the case of Ukraine.

However, it should be noted that this region of Central Europe already had a long tradition of attempts at regional integration, thus having a marked Central European identity, although this concept had no geographical and scientific basis and varied throughout history, to the interest of the powers. Proposals for the creation of a Mitteleuropa, "the territory where Germanic culture constitutes the common denominator" (Joseph Platsch, Mitteleuropa, 1904), added, in a perspective more favorable to the interest of the small powers that composed it, to others more focused on the Slavic states and Hungary, as the the case of the Intermarium (proposal by Marshal Pilsudski, President of Poland in the interwar period), a construct that had the advantage of being a real security glacis 
against Russia. Other views from recent historians and analysts have extended this concept to Romania (Elena Zamfirescu, in her Mapping Central Europe) or even the Balkan countries according to a definition of Central Europe as the space of influence of four great empires: Germanic, Austro-Hungarian, Russian and Turkish (Frédèric Mitterrand, Les Aigles Foudroyées). This broadening of the concept makes sense considering the recent past.

In fact, regardless of whether we call it Central Europe or Central and Eastern Europe (as some argue), there is a range of countries which, due to their recent historical experience and its implications at various levels, feel that they have common problems and challenges that will only gain from being addressed by all together. Even without calling into question other geopolitical commitments arising from its bet on European construction.

As a result of the above characteristics, it will not be strange to note that among these countries, there is a relatively high percentage of conservative "populist" governments contesting the federal model for Europe, immigration policies (likely to pose challenges to its newly acquired identity) and even some of the economic priorities for the European Union.

\section{Central Europe space and historical context}

Although this work is not about the concept of Central Europe, it is considered that given the complexity of the region and the numerous integration proposals put forward over time, there is every convenience that we should look at, however briefly, those, before we study the latest: the Three Seas Initiative.

The complexity of the region is based on several factors, first the multiplicity of small powers that make it up, resulting mostly from the dismemberment of great empires, and the particularity of including all different languages, cultures and ethnicities, and these are rarely confined to just one state. They still have recent borders and, in some cases, much discussed, so it is natural that conflicts, claims and attempts of integration into wider spaces have multiplied, either under the broad concept of Empire or Federation.

These integration initiatives have taken many forms, from mere customs unions to larger federal geopolitical projects involving a larger or smaller number of countries. From more homogeneous designs, spanning only the two empires - the German and the AustroHungarian - to the broader concepts extending to the Baltics, the Balkans and even Italy and neighboring countries, as is the case in Belgium or the Netherlands. Some even propose models that evolve towards integration across the continent.

For this work we will adopt a broader view of Central Europe. This is, by the way, the spirit of I3M, from the Baltic Sea to the Balkans, it also encompasses the riparian states of the Danube, the main central European river, which flows into Germany and flows into Romania's Black Sea coast.

This area is bounded to the north by the Baltic Sea and the great European plain, which runs from the Elbe River to the Gulf of Finland and is a major concern for the safety of Poland. In the center stand out the Czechs mountainous terrain, but also the famous Gate of Moravia, which gives way to several countries and is an important point for projects of I3M. The southernmost Carpathians follow, entering several countries and surrounding the great plain of Pannonia. To the west, the Alps span Austria and Slovenia and to the south the Balkans border the peninsula of the same name. Finally, Transylvania, a plateau region, which was the entry point and historic establishment of German-speaking minorities, still residing in the territory of present-day Romania.

This is a concept that deliberately leaves Germany out, even considering that it was precisely this country that, since Bismarck, but especially since William II, made it 
impossible to integrate the whole region corresponding to the territories of the German Empire and the Austro-Hungarian Monarchy. Moreover, in the specific case of the Three Seas Initiative, Germany, while having observer status, turns out to be "on the other side", in that, with the construction of Nordstream II and the direct supply of Russian gas to Europe through its territory, it is at the center of the threat of energy dependence for all of Central Europe.

Bismarck's option for the creation of the German Empire and thus setting aside the ideal of Grossdeutschland (the union of Germany and Austria), will have a big impact on the hope of setting up a Reich (Empire) capable of assuming itself as a platform for the framing of all these small, mostly Slavic nations that do not see themselves in the dual Austro-Hungarian monarchy. "What they admire in the Reich the supporters of Mitteleuropa, is of being, not a state in the modern sense of the term, but a principle of organization, a supranational notion, a center of attraction for the new states, which adaptive federalism of institutions would allow to integrate" ${ }^{\prime 2}$.

This federal ideal for the organization of central European space was particularly alive among Slav authors, as Jacques Droz points out: "numerous among the Slavs were those who recognized that there would be no other solution to the organization of central Europe than national autonomy within a federation of states" ${ }^{\prime 3}$.

Other integration proposals focused mainly on the economic field, such as that advocated by Frédéric List, as early as 1840, through the creation of "a large economic space", "a vast federal state, constituting a commercial unit, encompassing the small neighboring nations - Denmark, the Netherlands, Belgium, Switzerland - which would see the Danube and the Mediterranean route open via the Habsburg states" ${ }^{\prime 4}$.

Several other proposals - like Gustave Höfken's (1842), Chancellor Schwarzenberg or Baron Karl von Bruck (1848) - defended the creation of a vast Zollverein, a continental customs union stretching from the North Sea to the Adriatic.

These initiatives, which will win numerous supporters, will have a first setback with Bismarck's creation of the Second Reich, which will make it impossible to unite with Austria, defeated in Sadowa. As Jacques Droz points out, "the ideology of Mitteleuropa, that is, the sense of the solidarity interests of the great states of Central Europe, between 1871 and 1914 knows an almost complete eclipse" ${ }^{\prime \prime}$. But in the meantime, the Slavonic nations of the Double Monarchy are stirring under the banner of the principle of nationality.

In 1917, taking advantage of the misfortunes caused by the war, German Friedrich Naumann presented one of the most interesting proposals for integrating Central Europe with his book "Mitteleuropa", which immediately became a bestseller ${ }^{6}$. His proposal was that the German Empire and the Austro-Hungarian Empire should take advantage of the signing of peace to create a union, a Mitteleuropa, which would constitute a large space capable of rivalling other great powers such as Russia and the USA. In a second phase, it would then be possible to accept applications from other European countries. The leadership would be German, but all nationalities would be respected.

However, during World War I, in the interwar period, and especially under the Third Reich, the Pangermanist ideas and the theories of the living space that will make the elites turn their backs on the idea of Mitteleuropa and start thinking more in terms of

2 Droz, Jacques, 1960. L'Europe Centrale. Évolution Historique de l'Idée de «Mitteleuropa», Paris, Payot, page. 26 [Author trad.].

Idem, p. 27.

Idem, p. 54.

Idem, p. 155.

Naumann, Friedrich, 1917. Central Europe, [translation by Christabel M. Meredith], New York, Alfred A. Knopf, (Classical Reprint Series, Forgotten Books, 2012). 
Osteuropa (East Europe) and in the vast spaces to the east, the famous Lebensraum (or "living space") which Hitler aimed at.

An important attempt at regional integration in Central Europe, and with the merit of being born in a non-Germanic country, comes with the 1919 project of Intermarium, proposed by the first President of the Republic of a Poland then reborn, Marshal Józef Pilsudski. It intended to create a federation of states between the Baltic Sea and the Black Sea, namely Poland, the three Baltic States (Estonia, Latvia and Lithuania), Finland, Belarus, Ukraine, Hungary, Romania, Yugoslavia and Czechoslovakia?. This is an important attempt but it will not materialize, so one of his followers, Polish Foreign Minister Józef Beck, will in turn propose the creation of a Central European Union including Poland, Czechoslovakia, Hungary, Scandinavia, the three Baltic States, Italy, Romania, Bulgaria, Yugoslavia and Greece. Another project that is just that.

Winston Churchill still attempts, at the end of World War II, to create a federation of small Central European nations ${ }^{8}$, which would constitute a glacis of security in relation to the Soviet Union. But Moscow strongly opposes. And these projects are not referred to anymore practically until the fall of the wall.

Some exceptions existed, proposals from intellectuals who spread their ideals in samizdat, but which did not have great expression. In 1953, Lieutenant Colonel F.O. Miksche, an exiled Communist Czechoslovak officer in London, vigorously defended the creation of regional federations in Europe, bringing together countries with identical interests, the same culture and economic interdependence. He considered that the Danube Basin could be "the core of future development for all of Central and Eastern Europe in the event of a collapse or diminution of Russian pressure ${ }^{\prime \prime}$. In his work, the author specifies this idea a little better when he states that "the problem of the creation of a Central European Federation can only be overcome in one way, through a limited federation in an area with favourable conditions, and which would constitute a nucleus to which neighbouring nations could later join. The regions inhabited by the Austrians, Czechs, Hungarians and Slovaks, which are geographically, culturally, psychologically and economically complementary, have favourable conditions for the initial federation"10. This is a very limited region, leaving out the Baltics, but also Poland, Romania or the Balkans.

Already at the end of the twentieth century, there were also some proposals for regional co-operation, of which we stand out:

In 1989, four countries launched the Quadragonal project - Italy, Austria, Hungary and Yugoslavia. It was an initiative of the Italian President Gianni De Michelis and sought to counterbalance the growing German influence in the region. The initiative soon expanded to 18 countries, taking the name of the European Central Initiative, but the variety of agendas and the Yugoslavia War ultimately deprived it of any success.

Most important was the creation of the Visegrad Group - with the participation of Poland, Czechoslovakia (later the Czech Republic and Slovakia) and Hungary - which, after a weak start-up phase, began to gain importance after the rise to power in Russia of President Putin.

\footnotetext{
Chodakiewicz, Marek Jan (2016). Intermarium: The Land Between the Black and Baltic Seas", Routledge, $1^{\text {st }}$. ed.

8 Droz, Jacques, op. Cit, page 264.

9 Miksche, F.O. (1953). Danubian Federation. A Study of Past Mistakes and Future Possibilities, England, Kenion Press Ltd., Bucks (introduction by Philip Dunant, viii+38 pags.), pag. 4. [author trad.].

10 Op. Cit., page 33.
} 


\section{The Three Seas Initiative}

The Three Seas Initiative (I3M), an ambitious geopolitical project launched by Poland, was created in August 2016 in Dubrovnik, on the Adriatic coast of Croatia, at the first I3M Summit with twelve Member States: from North to South, a wide range covering Estonia, Latvia, Lithuania, Poland, the Czech Republic, Slovakia, Hungary, Austria, Romania, Bulgaria, Slovenia and Croatia. A range that, while geographically and demographically significant, is not economically significant. We are talking about "a region that represents $28 \%$ of the European Union's territory and $22 \%$ of its population, but only $10 \%$ of its GDP"11. The aim was to promote the development of central European infrastructures, which would allow further economic development and thus bring that region closer to the levels of other European countries.

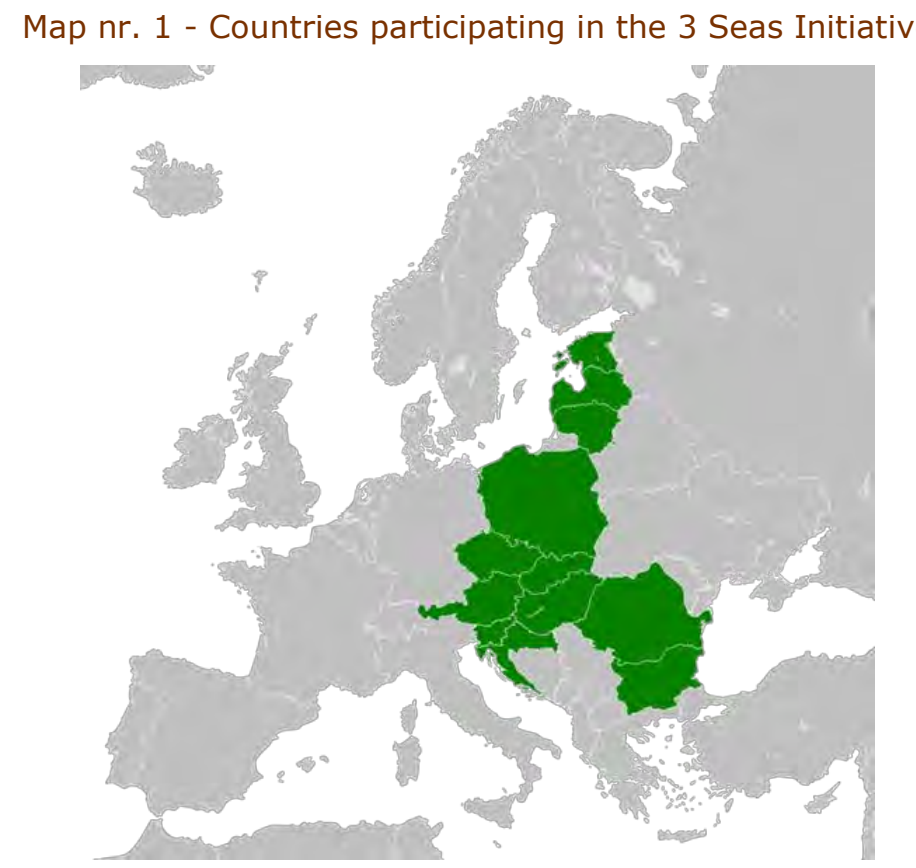

Source: https://es.wikipedia.org/wiki/Iniciativa Tres Mares

In July 2017, the II Summit took place in Warsaw, which was attended by US President Donald Trump, who praised this initiative, while launching harsh attacks on the Nordstream II pipeline and Germany itself for launching this project with Russia while supporting the sanctions policy regarding the conflict with Ukraine.

The Third Summit took place in Bucharest in September 2018 and its main objective was to identify the priority projects to be developed. The meeting was a success and the Business Forum was created ${ }^{12}$ and I3M Network of Chambers of Commerce was established. A Declaration of Intent was also signed for the creation of the Three Seas Investment Fund. But the summit also had a major international impact by counting with the presence of "strategic partners", notably the USA, the EU and Germany, the latter with observer status and invited by Poland ${ }^{13}$.

11 PWC \& Atlantic Council (2017). The Road Ahead - CEE Transport Infrastructure Dynamics (https://www.pwc.pl/pl/pdf/the-roa-ahead-raport-pwc-atlantic-council.pdf).

12 In addition to creating an enabling environment for the implementation of I3M's priority projects, the Business Forum will also have a role in monitoring the progress of projects under implementation.

13 The issue of a possible future inclusion of Germany in I3M as a Member State has been debated in the margins of its meetings as it is a major challenge. While, on the one hand, the resulting potential is evident, 
The Fourth Summit, held on 5 and 6 June 2019 in Slovenia, was intended to make a first progress report on the development of the projects identified in Bucharest. However, their results came to light as the major development turned out to be the effective creation of the Three Seas Fund, which is under the administration of Poland, Romania and the Czech Republic and already has $\mathbf{5 0 0}$ million euros, still a very small amount for the overall needs of this project. The idea that it is time to move from political statements to actions was consensual. However, it is fair to point out that we are beginning to see a change in the perceptions of Germany and the European Union regarding I3M, with the first discussing internally the possibility of accession and with Brussels considering that this Initiative is fully in the spirit of European integration and therefore will be available to support several of its projects.

About the character and objectives of I3M much has been said. Its creators, who refuse any reference to geopolitics, argue that it is merely an initiative aimed at developing regional infrastructure and thus favoring European integration through the convergence of their economies with those of Western Europe ${ }^{14}$. This project will allow this region to take full advantage of its central position in Europe and the fact that it has a good network of contacts with the West and the East. It thus allows the north to be brought closer to the south and to the east to be brought closer to the west, while ending the limitations of some states that had no access to the sea.

Its enemies, however, see it as only a form of US interference intended to sell its shale gas (shale gas) to a continent that, it seems, will be the world's largest gas consumer. Others finally consider that there is also an attempt here to create a region with a different political and economic model than Brussels (although perfectly framed in the EU). The reality will be perhaps different from all these interpretations and perhaps have some of them all.

I3M was officially created as a way of achieving major regional infrastructure projects in three major fields: energy, transport (road and rail) and the digital field (communications), so as to overcome the relative backwardness that these countries still have in these areas. As synthesized by Alexandr Vondra ${ }^{15}$, at the energy level are on the table four major projects:

- "A pipeline connection to two large LNG terminals (liquefied natural gas): Swinoujsce, on the Baltic coast [from Poland], already operational; e Krk, a Croatian island of the Adriatic Sea";

- The "Gas Interconnection Poland-Lithuania (GIPL), integrating isolated gas markets from the Baltic countries into the EU network";

- "The North-South Gas Corridor (BRUA), a two-way pipeline system. In the South it will connect to offshore explorations in the Black and Caspian Seas (via TANAP pipeline in Turkey). In the West, it will integrate the Balkans into the EU network via Baumgarten in Austria";

particularly in terms of financing, it is also clear that problems may arise, especially in the energy sector. Germany, however, has only applied for observer status because it wants to be present - and influence an initiative that brings together neighbouring Central Europe and is the site of global competition between the US, Europe, China and even Turkey (vide Korybko, Andrew (2018). Germany's Request to Partner with the Three Seas Initiative Is a Win for Poland", Global Research, available at https://www.globalresearch.ca/germanys-request-to-partner-with-the-three-seas-initiative-is-a-win-forpoland/5652168.

14 "A citizen of ancient Europe has on average twice as many kilometers of motorway as one in Central Europe", in Patricio de Antonio, 2017. La iniciativa de los Tres Mares que conectará la Vieja y la Nueva Europa, available at https://ideas.pwc.es/archivos/20171013/iniciativa-de-los-tres-mares-conectara-viejay-nueva-europa/.

15 Vondra, Alexandr (2018). Regional Integration at the Three Seas Summit, available at https://emergingeurope.com/voices/regional-integration-at-the-three-seas-summit/. 
- "The pipeline Eastring, which will link existing pipelines in Bulgaria, Romania, Hungary and Slovakia."

With regard to major transport infrastructure projects, according to the same author, the following should be mentioned:

- "Via Carpathia, a motorway linking a Baltic port (Klaipeda, Lithuania) to an Aegean commercial hub (Thessaloniki, Greece);

- Modernization of the north-south motorway along the E65 motorway which will connect the Baltic (from Szczecin, Poland) to the Adriatic Sea (Rijeka, Croatia);

- Rail Baltica, connecting Warsaw, Kaunas (Lithuania), Riga, Tallinn and Helsinki;

- Rail 2 Sea, linking Gdansk, Poland, Constance, a Romanian Black Sea port"16.

The planned digital infrastructures and supported by the EU are as follows ${ }^{17}$ :

- RuNe Project (Rural Networks), a broadband fiber network connecting areas of Slovenia, the Autonomous Region of Friuli-Venezia Giulia (Italy) and the regions of Primorsko-Goranska and Istarska (Croatia);

- Project RO-NET Broadband, creation of broadband infrastructure in less favored areas of Romania.

- However, I3M has also launched a "Digital 3 Seas Initiative" (D3SI), which predicts several areas of cooperation ${ }^{18}$ :

- Cybersecurity;

- 3 Seas Digital Highway, aiming to fill the gaps in terms of communications infrastructure, including fiber optics and 5G technology;

- Launch of joint technology initiatives;

- Implementation of the Industry 4.0 program;

- Strengthen e-commerce networks ${ }^{19}$

This is a very ambitious set of initiatives that will have a major impact on these countries and across Europe. Let's not forget that many of these countries are landlocked states with no access to the sea. These infrastructures will now give them access to three seas and thus greatly contribute to greater independence and room for maneuver in their policies. However, for the implementation of these projects there is a need to secure substantial funding that cannot be guaranteed by Member States alone. Thus, in addition to appeals to the European Union, US investments have already been secured (especially in the field of energy) and Chinese (although these have not yet materialized). It was also decided to create the Three Seas Fund (TSF), with a duration of 30 years and which

16 Op. Cit.

17 European Commission, 2018. The Three Seas Initiative Summit: European Commission Investments in Connectivity Projects Bucharest, Romania.

18 The Kosciuszko Institute, 2018. The Digital 3 Seas Initiative: a call for a cyber upgrade of Regional Cooperation, White Paper, Poland, available https://ik.org.pl/wpcontent/uploads/white_paper_the_digital_3_seas_initiative-1.pdf.

19 Only a selection of the most emblematic projects has been presented here. For a complete list of these projects, see "Priority Interconnection Projects" of the Slovenian Presidency. 
aims to secure a financing of 100 billion euros (from an initial investment of 5 billion euros from Member States). A non-negligible scale.

Given the above, it is easy to see the geopolitical implications of this Initiative. First and foremost, the region is at the center of a titan struggle to supply natural gas to Europe, it being known that this will be one of the largest markets worldwide. On the other hand, there is a growing concern to ensure energy independence for the region that avoids the current over-reliance on supplies from Russia and which will be channeled through Germany (the aforementioned Nordstream II). In fact, Member States ${ }^{20}$ are for the most very distrustful of this German-Russian project and consider it necessary to promote their energy independence by diversifying supplies.

The US has openly spoken out against Nordstream II, with President Donald Trump, at the I3M conference in Warsaw, strongly attacked Germany's energy policy, pointing to the contradiction between, on the one hand, support for the sanctions policy against Russia because of the conflict in Ukraine and, on the other hand, payment of millionaire sums of Russian hydrocarbons, which is a significant help to their economy.

But the implications of this Initiative are broader and in fact include US interests in supplying shale gas to Europe (a growing market), which makes Washington one of its main allies. But for US supplies to come to fruition on the intended scale, there are complex issues that must be resolved before, such as whether the countries of the region will opt for this solution, being the shale gas prices considerably higher than Russian gas, but constituting an instrument for the diversification of energy sources ${ }^{21}$. A first step was taken by Poland, in 2017, when making its first shale gas imports from the US ${ }^{22}$. Polish President Andrzej Duda even stated at the Warsaw Summit his country's intention to conclude long-term contracts with the US for these supplies, although complicated price negotiations have yet to be held, which the US President has said are already likely to increase ${ }^{23}$.

In contrast to Poland's choices, we saw that US Vice President Mike Pence's visit to Hungary in February 2019 was not the success that some had hoped for. The talks were tense and when Mike Pence tried to convince Hungary not to support Russian proposals to extend the Turkish Stream to Central Europe and instead opt for supplies from the US, the response received was at least cold. While the truth is that these US ambitions, for now, are just that, but the Russians can guarantee an immediate continuous supply at much lower prices.

For its part, China also sees I3M with great interest, which could enable it to use this huge infrastructure network (particularly as regards ports, motorways and railways) as part of its project One Belt, One Road. Although cooperation between China and the

20 With particular emphasis on Poland that with the Nordstream II, will lose most of the rights of way of Russian gas through its territory.

21 Although the price issue is of course important, the growing influence of geopolitics on the EU energy market must also be considered.

22 However, it should be noted that Poland aims to become a regional energy hub that could eventually replace Russia in the supply of natural gas to Ukraine and Moldova. It is also making major prospects for local shale gas production and has already drilled several holes.

23 Engdahl, William, 2017. Initiative polonaise des Trois Mers. Quel en est l'enjeu géopolitique?, New Eastern Outlook, available at http://lesakerfrancophone.fr/linitiative-polonaise-des-trois-mers-quel-en-est-lenjeugeopolitique. 
countries of the region is based on the initiative " $16+1 " 24$, Beijing is following with increasing interest the developments of this Initiative ${ }^{25}$.

On another level - more controversial - it is also important to note that among these countries are some of the most conservative states in Europe, such as Hungary, Poland, Austria or Slovakia, which have been challenging some of Brussels' policies, particularly in terms of sovereignty concessions (the federal way), the euro, immigration and defence ${ }^{26}$. Thus, suspicions have been raised that they might be trying to create, within the European Union, an alternative integration model to the Paris-Berlin axis (today increasingly Berlin-Paris), which has always been denied by the promoters of I3M, which have been repeatedly saying that it is part of the EU and is limited to infrastructure cooperation. However, no one is unaware that leaders like Viktor Orban, or Italian Matteo Salvini, now on a desert crossing after the alliance broke that held him in power, have been sponsoring the idea of a reformulation of the European Union in a more egalitarian project, or homogeneous in its distribution of the power of its Member States, and with a different vision of the future.

Growing suspicions of these countries towards Germany have been visible (especially after the announced Nordstream II, accused of being at the bottom and essentially "antiEuropean", because it aims to circumvent Poland by ostensibly passing through the Baltic Sea bottoms, marginalizing it on its way) and the French projects on European defense and a deepening of integration (with the consequent compromise on newly acquired sovereignty). Most of these countries have also been challenging Brussels' migration policies, which they consider to be contrary to European interests having clearly expressed the refusal to accept in their countries the quotas of immigrants which have been assigned to them.

In turn, at the 55th edition of the Munich Security Conference in January 2019, Chancellor Angela Merkel argued that the issue of dependence on Russian gas cannot be reduced to a discussion about whether it is coming from the Ukrainian gas pipeline or the Nordstream II, having been available for an open discussion that also includes the supply of US LNG to Europe. In contrast, at the same conference, US Vice President Mike Pence expressed his country's discomfort over this issue, noting that the US will not be able to guarantee the defense of the West if its allies continue to depend on the East, and has expressed itself as "vigorously against Nordstream II".

This shows, with some sharpness and clarity, the scale of the issues at stake and, contrary to the claims made by its leaders, I3M is clearly an Initiative with the greatest geopolitical relevance.

24 Chinese initiative to deepen cooperation with various European States: Albania, Bosnia and Herzegovina, Bulgaria, Croatia, Czech Republic, Estonia, Hungary, Latvia, Lithuania, Northern Macedonia, Montenegro, Poland, Romania, Serbia, Slovakia and Slovenia. Cooperation focuses on infrastructure, education and culture, with three priority areas: infrastructure, cutting-edge technologies and green technologies.

25 Poland has expressed some distrust of the initiative "16 +1" considering that this has not led to major practical embodiments. It has also been showing some discomfort over the trade imbalance in favour of China.

26 Most of these states continue to consider that NATO is the guarantor of their independence and security and have very strong bilateral cooperation with the US. 


\section{Conclusions}

This initiative, of obvious geopolitical importance, nevertheless presents several important challenges. First, the amount of investment necessary to achieve its various projects, especially those relating to energy and road and rail infrastructure, which can only be guaranteed through external investment. The European Union has already supported some of them (most of which falls, moreover, in larger projects of the European Union intended for all Member States). China, for its part, has not yet achieved anything very significant, with countries already accusing it of being no more than declarations of intent - and the US have only supported projects in which they have a direct interest, such as those in the energy sector. Thus, most of this millionaire investment remains to be secured, and this in a time that, it seems, will cool the economy. The Business Forum, being open to the participation of third countries, could play an important role in this field; hopefully so.

A major challenge for the US will be to convince Member States, once again in a climate of economic uncertainty, to buy shale gas from across the Atlantic, more expensive and more difficult to handle, arguing the need to diversify supplies. At the same time, these countries will have to face both Russian and German pressure. The fact is that natural gas supply needs are large and likely to grow considerably in the future, so the temptation will be to turn to the best-priced suppliers, although the United States will do everything to make their shale gas part of this equation.

Maintaining the cohesion of this set will not be easy either, especially if I3M cannot count on the support of the European Union (it is therefore important not to harass Germany too much). Making the situation more difficult, there is a reference to the existence of different security perceptions, very uneven levels of economic development and differences at the political level.

Finally, while the merits of this Initiative are clear, it does not appear that from the political point of view it will gain susceptible dynamics to be as an alternative to the current model of European integration. There are several reasons for this, but the region's dependence on EU funds for the development of these projects, makes it dangerous to choose to throw political challenges on Brussels orientations or to antagonize the major EU powers.

From an economic point of view, it seems that everyone will win (and not just the Member States) in the development of these infrastructures, capable of creating greater contact and business dynamics in the region.

This leads to the belief that I3M could succeed if it maintains its current orientation to present itself as a regional initiative aimed at developing the region's infrastructure within the EU framework, but without having to be overly dependent on Union mechanisms, always slow and demanding broad consensus difficult to achieve. From the point of view of security, its promoters have always stressed the importance of the transatlantic relationship, specifically in order to serve as a counterweight to the Franco-German or German-French axis, if preferred.

The next summit in Slovenia is expected to be already devoted to the implementation of the projects defined in Bucharest. This is a litmus test for assessing the ability to capture 
the necessary investments and the political will of the states to withstand the aforementioned pressures they have been subject to.

\section{References}

Antonio, Patrício de (2017). "La iniciativa de los Tres Mares que conectará la Vieja y la Nueva Europa", available at https://ideas.pwc.es/archivos/20171013/iniciativa-de-lostres-mares-conectara-vieja-y-nueva-europa/

Calheiros, Bernardo (2002). O fim do bloco de Leste e o renascimento da Europa Central como realidade geopolítica. Lisboa, Tese de Mestrado, Ed. do Autor/ISCSP

Chodakiewicz, Marek Jan (2016). Intermarium: The Land Between the Black and Baltic Seas, Routledge, $1^{\text {st }}$. ed.

Droz, Jacques (1960). L'Europe Centrale. Évolution Historique de l'Idée de «Mitteleuropa». Paris, Payot

Engdahl, William (2017). "L'Initiative polonaise des Trois Mers. Quel en est l'enjeu géopolitique?". In New Eastern Outlook, available at http://lesakerfrancophone.fr/linitiative-polonaise-des-trois-mers-quel-en-est-lenjeugeopolitique

European Commission (2018). The Three Seas Initiative Summit: European Commission Investments in Connectivity Projects. Bucharest, Romania

Guedes, Armando Marques, with Radu Dudau (2012). "European Energy Security: The Geopolitics of Natural Gas Projects, London". In Ruxandra Ivan (org.). New Regionalism or No Regionalism? Emerging Regionalism in the Black Sea Area

Górka, Marek (2018). "The Three Seas Initiative as a Political Challenge for the Countries of Central and Eastern Europe". In Sciendo, Politics in Central Europe, vol. 14, no 3 (ISSN: 1801-3422), available at https://www.researchgate.net/publication/331871310_The_Three_Seas_Initiative_as_a _Political_Challenge_for_the_Countries_of_Central_and_Eastern_Europe

Gvosdev, Nikolas K. (2019). "Why Europe Won't Go for American Natural Gas". In The National Interest, available at https://nationalinterest.org/feature/why-europe-wont-goamerican-natural-gas-45557

Korybko, Andrew (2018). Germany's Request to Partner with the Three Seas Initiative Is a Win for Poland, Global Research, available at https://www.globalresearch.ca/germanys-request-to-partner-with-the-three-seasinitiative-is-a-win-for-poland/5652168

Miksche, F.O. (1953). Danubian Federation. A Study of Past Mistakes and Future Possibilities, England, Kenion Press Ltd., Bucks, (introduction by Philip Dunant, viii +38 págs.)

Nogueira, José Manuel Freire (2008). "Recursos, Energia e Geopolítica". Revista Geopolítica. Lisboa: Centro Português de Geopolítica

Naumann, Friedrich (2012). Central Europe [translation by Christabel M. Meredith]. New York, Alfred A. Knopf (Classical Reprint Series, Forgotten Books). 
PWC \& Atlantic Council (2017). The Road Ahead - CEE Transport Infrastructure Dynamics, available at https://www.pwc.pl/pl/pdf/the-roa-ahead-raport-pwc-atlanticcouncil.pdf

The Kosciuszko Institute (2018). The Digital 3 Seas Initiative: a call for a cyber upgrade of Regional Cooperation, Livro Branco, Polónia, available at https://ik.org.pl/wpcontent/uploads/white_paper_the_digital_3_seas_initiative-1.pdf

The Three Seas Initiative (2019). Priority Interconnection Projects, available at https://irpcdn.multiscreensite.com/1805a6e8/files/uploaded/2018\%20List\%20of\%20Interconnect ion\%20Projects.pdf

Tomé, Luís (2018). Geopolítica da Rússia de Putin: Não é a União Soviética, mas gostava de ser..., available at http://www.scielo.mec.pt/pdf/ri/n60/n60a05.pdf

Vondra, Alexandr (2018). Regional Integration at the Three Seas Summit, available at https://emerging-europe.com/voices/regional-integration-at-the-three-seas-summit/

Zamfirescu, Elena (1996). Mapping Central Europe. Haia: Clingendael Paper 


\title{
RIGHTS OF MIGRANTS: NOTES ON THE JURISPRUDENCE OF THE INTER- AMERICAN COURT OF HUMAN RIGHTS
}

\author{
María Teresa Palacios Sanabria \\ maria.palacios@urosario.edu.co \\ Doctor in Law and holder of a Master degree in Constitutional Law from Universidad de Sevilla, \\ Spain. Associate Professor at the Universidad del Rosario (Colombia) and lawyer of the \\ Universidad del Rosario. Director of the Human Rights Research Group of the Faculty of \\ Jurisprudence of the Universidad del Rosario.
}

\begin{abstract}
The rights of migrants represent a challenge for States, because their guarantee evidences the permanent tension between the sovereignty of the States and the protection of human rights in the international context. This article will analyse if it is really possible to affirm the existence of a true evolutionary development of the jurisprudence of the Inter-American Court of Human Rights in a contentious and consultative way and which, therefore, may contribute to the improvement of the rights of migrants in the IACHR. To this end, the text will address the following parts: I) Regulatory framework oriented to the sovereignty of States; II) The progressive contentious jurisprudence of the Inter-American Court III) The advisory opinions: integrating elements of rights and; IV) Conclusions.
\end{abstract}

\section{Keywords}

Human rights, Inter-American Court of Human Rights, progressive development, interAmerican jurisprudence, international migration

\section{How to cite this article}

Sanabria, María Teresa Palacios (2019). "Rights of migrants: notes on the jurisprudence of the Inter-American Court of Human Rights". JANUS.NET e-journal of International Relations, Vol. 10, N.0 2, November 2019-April 2020. Consulted [online] on the date of the last visit, https://doi.org/10.26619/1647-7251.10.2.9 


\title{
RIGHTS OF MIGRANTS: NOTES ON THE JURISPRUDENCE OF THE INTER- AMERICAN COURT OF HUMAN RIGHTS ${ }^{1}$
}

\author{
María Teresa Palacios Sanabria
}

\section{Introduction}

The human rights recognized in international treaties are predicated by all people and International Human Rights Law (IACHR), under the claim of universality ${ }^{2}$ (UN, 1993: 19), has established the reasons why they cannot have discriminatory treatment. ${ }^{3}$ The Inter-American System for the Protection of Human Rights (SIDH) has not been the exception and, through the evolution that it has had regarding the emergence of its bodies, regulations and jurisprudence, has been concerned with establishing parameters for the protection of human rights in the American region, applicable to all persons subject to the jurisdiction of the member states. Thus, it is evidenced by the treaty establishing the Organization of American States (OAS), by pointing out in Article 3.i that: "The American States proclaim the fundamental rights of the human person without distinction as to race, nationality, creed or sex" (OAS, 1948).

With the creation of the Inter-American Commission on Human Rights (IACHR) in 1959 and subsequently the Inter-American Court (1969), as well as with the adoption of general regional treaties and thematic sectorial treaties, a process of evolutionary development of regional jurisprudence was promoted, which determines the scope of the obligations of the States party to them and accept the jurisdiction of the court for the monitoring of the fulfilment of such commitments.

Thus, it is up to the Inter-American Court, as supreme autonomous and judicial authority of the IACHR, to apply and interpret the provisions contained in the ACHR. Both contentious decisions and the advisory opinions of the Court have dealt with a great diversity of issues and rights and have been described by some doctrine makers as progressive, courageous and committed to the application of the "pro persona" principle, which has implied the extension of the catalogue of rights contained not only in the ACHR,

1 The translation of this article was funded by national funds through FCT - Fundação para a Ciência e a Tecnologia - as part of OBSERVARE project with the reference UID/CPO/04155/2019, with the aim of publishing Janus.net. Text translated by Carolina Peralta.

2 See the Vienna Declaration and Action Programme (article 5, 1993).

3 Universal Declaration of Human Rights, (art. 2, 1948) and the 1966 agreements. See definition of discrimination in the International Convention on the Elimination of All Forms of Racial Discrimination (article $1.1,1965)$. 
but in the other treaties that are part of this regional context (Quispe, 2016: 229) (Núñez, 2017: 80) (Ovalle, 2012: 601).

Although a significant number of rights are recognized to every person, in the case of foreigners, countries can legitimately establish distinctions that are not considered prohibited, which question the principle of equality (Lucas, 2015: 90). Consequently, it is common for their exercise to be restricted to a very limited framework, which is present in migration policies. In parallel, the reality of migration is increasing and according to the OAS, between 2012 and 20167.2 million people left their country in the Americas (OAS, 2017: 4). In this context, it is of interest to analyse how the contentious and advisory jurisprudence of the Inter-American Court has behaved in this area, and identify which are its main contributions in order to demonstrate the beginning of the construction of an emerging normative corpus on the rights of foreigners and migrants, which results in the creation of interpretative parameters for the OAS member states, but which at a comparative level can inspire developments in other regional contexts.

The document is the result of research on a project called "The right to a dignified life in the context of immigration"4, which uses a dogmatic methodology of documentary analysis of primary normative, jurisprudential and doctrinal sources of the IACHR, but which in this case will focus on the activity of the Inter-American Court, although reference to the reports of the IACHR, as well as to other instruments that are part of the IACHR corpus, may be made

\section{A normative framework oriented to the sovereignty of States}

\subsection{American Declaration of $\mathbf{1 9 4 8}$}

In order to refer to the decisions of the Inter-American Court of Human Rights, it is necessary to review some regional norms such as the American Declaration of Rights and Duties of Man of 1948 (DADH) $)^{5}$ since it provides that the (...) the American States have recognized that the essential rights of man do not arise from the fact of being a national of a certain State but are based on the attributes of the human person" (OAS, 1948 A: 1).

This leads to reflection on the true notion of equality between people, in which the value of individuals prevails without taking into account any legal-political considerations with the territories for the allocation of rights. However, this ideal is diluted as in the operative part of the American Declaration of the Rights and Duties of Man DADH, art. II, the nationals of the States are only recognized the right to select their residence and to move freely through the territory, and allusion to the right of entry is omitted. For its part, the Universal Declaration of Human Rights ${ }^{6}$ (UDHR) does expressly recognize in Article 13 the right of entry, without this being replicated in subsequent regulatory developments. ${ }^{7}$ This may be due to the entrenched concept of sovereignty of the States that translates

The aforementioned project is part of the doctoral work conducted at the University of Seville, which ended in 2012, but continues to generate products given the author's interest in the theme.

5 Signed in Bogotá in 1948 and amended by the Protocol of Buenos Aires in 1967, by the Protocol of Cartagena de Indias in 1985, by the Protocol of Washington in 1992, and by the Protocol of Managua in 1993.

6 Adopted by the General Assembly of the United Nations on 10 December 1948, by resolution 217 A (III).

7 The right of entry is not recognized in the ICCPR or in the regional treaties. 
into the design of immigration policy through visas, entry controls and permanence of foreigners. ${ }^{8}$

\subsection{Some applicable treaties}

The normative omission of the right of entry is evidenced in the American Convention on Human Rights (ACHR) ${ }^{9}$ in Article 22, which states that: "Everyone who is legally in the territory of a State has the right to move through it and to reside in it subject to legal provisions" (OAS, 1969: 8). This is a reproduction of the provisions in the universal context, since the ICCPR of $1966^{10}$ in article 12 conditions the right of entry, freedom of movement and residence, to persons who are legally within the territory of the State. UN, 1966). ${ }^{11}$ In accordance with the foregoing, it is clear that for the current IACHR, the right of entry is non-existent and that from there, the States retain a high margin of discretion that materializes in the restrictive exercise of the rights of foreigners.

In addition, the International Convention on the Elimination of All Forms of Racial Discrimination (UN, 1965), in defining discrimination excludes the distinctions that happen through the application of the concept of citizenship and non-citizenship (art.1.2 CERD), empowering countries to grant differentiated treatment not constituting discrimination (Palacios, 2012).

\section{The progressive contentious jurisprudence of the Inter-American Court in favour of the rights of migrants}

In the previous section some basic norms were enunciated, from which the States limit the exercise of the rights of foreigners, evoking their national security, public order or general interest. For this reason, it is appropriate to analyse the characteristics that the jurisprudence of the Inter-American Court has had in this matter, since the court turns to various methods of interpretation provided for in the Vienna Convention on the Rights of Treaties (OImos, 2017: 3). This will allow us to identify elements that demonstrate the existence of a true evolutionary development that establishes some limits to the sovereignty of States regarding the treatment of foreigners. In this reflection, progressive development of human rights is understood as the normative and jurisprudential evolution that results in the greater protection of the rights of foreigners as a path to restricted equalization (Gomez, 2003). On the other hand, it is valuable to examine to what extent the Inter-American Court makes use of its two functions to complement the framework of the rights of foreigners, that is, if the considerations it reaches in the exercise of the contentious function are replicated in the jurisprudence of the consultative order.

8 Article 13 of the UDHR: "Everyone has the right to move freely and to choose his residence in the territory of a State. Everyone has the right to leave any country, including his own, and to return to his country".

9 Adopted in San José, Costa Rica, on 22 November 1969, effective on 18 July 1978.

10 Adopted and open for signature, ratification and accession by the General Assembly in its resolution 2200 A (XXI) of 16 December 1966, effective on 22 March 1976.

11 Article 12.1. Any person who is legally in the territory of a State shall have the right to move freely through it and to freely choose his residence therein. 


\subsection{A timely and guarantee ensuring jurisprudence}

The contentious function of the Inter-American Court is set forth in Articles 61, 62 and 63 of the ACHR and is regulated in several norms of the Regulations of the same corporation (OAS, 2009). The main purpose of this competence is to carry out a process of normative application to specific facts to determine whether or not there were violations in the light of the ACHR and derive from there international responsibility against the alleged infringing State. Therefore, the Inter-American Court must issue a judgment in which it will have to provide for measures of reparation, satisfaction or guarantees of non-repetition. (Roa, 2015:64). This is how it is up to it to verify the veracity of the denounced facts and decide if they can be considered a violation of the ACHR. (Ventura and Zovato, 1989:165). Although the cases ruled by the Inter-American Court regarding the rights of foreigners are not very numerous ${ }^{12}$, some issues can be identified, including the right to nationality, expulsion of foreigners and respect for the principle of non-refoulement, equality and non-discrimination, judicial guarantees and due process.

\subsubsection{The right to nationality is related to other guarantees}

The Ivcher Bronstein vs. Peru ${ }^{13}$ case $\left(I_{A C H R}, 2001\right)$ sets a parameter for the protection of the right to nationality by adoption of a naturalized Israeli citizen in Peru who had previously renounced his nationality of origin and who, due by a decision of an authority without competition, was at risk of statelessness. The Inter-American Court describes the right to nationality as a natural and inherent state of the human being (IACHR, 2001: para 86). It recognizes that the States, within their powers, regulate the acquisition and loss of this power, but the said sovereign power finds a limitation in "(...) the requirements of the integral protection of human rights" (IACHR, 2001: 88).

The ruling refers to previous advisory opinions ${ }^{14}$ (IACHR, 1984) in which the importance of nationality is recognized for the exercise of other rights, such as those derived from statelessness (IACHR, 2001: paragraph 91 et seq.). Likewise, it demonstrates the tension between the principle of sovereignty of the States and respect for human rights through the development of internal regulations ${ }^{15}$ (Carrillo, 2001: 32 ) to decide this type of issue.

In the case of the girls Yean and Bosico vs. The Dominican Republic ${ }^{16}$ (IACHR, 2005) ${ }^{17}$, the importance of nationality is reiterated and the Inter-American Court acknowledges the ignorance of this right in legal systems as an injury to the dignity of the person (IACHR 2005: para 179) every time the refusal by the Dominican State of the birth registration results in the cancellation of rights and places those affected in circumstances of extreme vulnerability (IACHR, 2005: para 180). For the IACHR, the right to nationality implies, on the one hand, the right to have a nationality so that the individual enjoys

2 If compared with the one that the ECHR produced.

13 IACHR, Ivcher Bronstein vs. Peru case, Series C, No. 74, of 6 February 2001.

14 See Advisory Opinion issued by the Inter-American Court of Human Rights, OC-4 of 1984 , Proposal to modify the Political Constitution of Costa Rica related to naturalization, Series A, No. 4, para. 32.

15 See Carrillo, J., Soberanía de los Estados y Derechos Humanos en Derecho Internacional Contemporáneo, second edition, Tecnos, Madrid, 2001, p. 32

16 IACHR, case of the girls Yean and Bosico vs. Dominican Republic, Series C, No. 130, of September 8, 2005..

17 The resolutions of provisional measures of 7 August 2000, 14 September 2000, 12 November 2000, 26 May 2001, 2 February 2006, 1 December 2011, 29 February 2012, and 7 September 2012 are of great importance in the subject. 
judicial protection for the relationship established with the State and on the other, the protection against arbitrary deprivation of the latter (IACHR, 2017: 11). In addition, that States are obliged to refrain from implementing practices that may favour the increase in statelessness cases (IACHR, 2017: 12).

For the Court, this right has a close relationship with the rights of children and the protection of the family, since the arbitrary denial of the birth registration and its delay constitutes a violation of the right to equality unknown of objective and reasonable criteria (Arlettaz, 2015: 431) and accentuates the condition of vulnerability of minors, as happened in the case of the girls Yean and Bosico vs. Dominican Republic ${ }^{18}$ (IACHR, 2005).

For the Inter-American Court, States must refrain from impeding access to registration and recognition of nationality by removing unnecessary requirements, especially when it comes to minors (IACHR, 2005: para 171). The omission caused the girls to be stateless, which resulted in victimization, as it established barriers to the exercise of a series of essential rights such as; personality development, access to education, development of own life project, access to the right to legal personality, right to name, dignified life, adequate standard of living, and family life.

The case of Dominican and Haitian people expelled vs. Dominican Republic ${ }^{19}$ (IACHR, 2014a) reiterates arguments of previous rulings on the treatment of Haitian or Haitianorigin persons in that country. By studying the right to nationality and family life, it addresses the best interests of the child from a differential approach ${ }^{20}$. The case determines that the condition of irregularity is a personal administrative situation that cannot be transferable or inheritable, meaning that the children of people who are undocumented cannot be affected by this situation and their right to nationality will have to be recognized (IACHR, 2014: para. 318). It is determined that the States may sovereignly establish the form of acquisition of nationality, however, they will have to reasonably set their restriction, so that a person who establishes links with the host State may not be considered as a transient in any case, since this must comply with a reasonable and temporary limit (IACHR, 2014: para 295).

From the considerations made, an evolutionary development of the scope of the right to nationality and legal personality is identified, as it turns out to be an essential element for the exercise of the right to name and for the effectiveness of nationality, which results in the recognition of guarantees that not only impact on civil and political rights, but also on economic, social and cultural ones.

\subsubsection{Procedural guarantees: a human right of all people}

The Vélez Loor v. Panama case ${ }^{21}$ (IACHR, 2010) deals with the protection of the rights to personal integrity and freedom and judicial guarantees based on human dignity 22 , noting that although the States have the exercise of their sovereignty, the power to

IACHR, case of the girls Yean and Bosico vs. Domenical Republic, Series C, No. 130, of 8 September 2005. 9 IACHR, Dominican and Haitian people expelled vs. Dominican Republic Series C, No. 282, 28 August 2014.

20 Paragraphs. $82-106,212-140$

21 IACHR, Velez Loor Vs. Panama case, Series C, No. 218, 23 November 2010.

22 This case concerns the arrest of Mr. Jesús Tranquilino Velez Loor, an Ecuadorian national detained in the border area of Darién (Panama) by police authorities in this country for not having documentation proving his stay in this country (par. 94). 
regulate the entry of nationals of other States has some limitations imposed by human rights.

Respect for such principles does not imply that the State cannot initiate any action to counteract irregular immigration, but that when adopting such measures, human rights must be respected. ${ }^{23}$ Foreigners detained in a social and legal environment different from their own with linguistic barriers exposes them to a condition of particular weakness ${ }^{24}$ (IACHR, 2010), an aspect that turns out to be incompatible in a democratic State.

The unworthy conditions of detention have been a concern for the Inter-American Court, because "(...) they may result in a violation of the absolute prohibition of cruel, inhuman or degrading treatment or punishment. ${ }^{25}$ In this sense, the States cannot invoke economic deprivations to justify conditions of detention that do not meet the minimum international standards in this area and do not respect the dignity of the human being" (IACHR, 2010: para 198). Likewise, these derive from a misconception that migratory administrative offenses involve crimes, which criminalizes migration ${ }^{26}$. It should be borne in mind that conditions worthy of detention should constitute good practice, applicable in detention centres exclusively for migrants and in prison establishments (IACHR, 2015: para 81 ) and comply with minimum circumstances such as legality, proportionality, reasonableness and prohibition of arbitrariness, as stated in the Nadege Dorzema $v$. Dominican Republic case. (IACHR, 2012: 133). From the foregoing, punitive migration policies that are intended to stop migrants in an irregular situation are incompatible with the ACHR (IACHR, 2014a: 359).

In immigration cases, the due process is a fundamental right of every migrant regardless of immigration status, which is recognized in the ACHR in Article 8. This is how every administrative and judicial body of a State party must respect it (IACHR, 2017: 44) and it is the duty of officials to be impartial and independent (IACHR, 2010: 108).

Another of the procedural guarantees in migratory causes consists of the obligation of the State that the person is presented before the competent authority and once this has happened, to watch over the fulfilment of the presumption of innocence in case an arrest has taken place (IACHR, 2014: 371), allow the measure or sanction to be reviewed, ensure that there are effective judicial remedies within the State (IACHR, 2010: 139), access justice and have legal assistance (IACHR, 2010: 254) or consular assistance if required, as happened in the case of Acosta Calderón v. Ecuador (IACHR, 2005a: 125) or establish communication with a person of his choice or consular agent, in case he has been legitimately detained as stated in the Tibi vs. Ecuador case (IACHR, 2004: 112).

23 These opinions had already been revealed in the Advisory Opinion, OC-18 of 2003, which will be analysed later in this paper.

24 See Ver IACHR Vélez Loor vs. Panama case, paras. 146-160

25 Committee against Torture, General Comment No. 2, Application of article 2 by States parties, 39 sessions, 2007, Doc. HRI/GEN/Rev.9 (Vol. II), of 27 May 2008. It is possible to point out that for the IACHR, the prohibition of torture, cruel, inhuman or degrading treatment or punishment is absolute, and in what relates specifically to immigrants, even those who are in a legal situation of irregularity, this rule has meant a strong limit to the individual expulsions or deportations of persons when in their home state their lives may be at risk or may be victims of torture, cruel, inhuman or degrading treatment or punishment.

26 The Report of the Special Rapporteur on the human rights of migrants, March 2011, paras. 13 and 15 , illustrates this. See Report of the Inter-American Commission on Human Rights, IACHR, Situation of human rights of unaccompanied families, children and adolescents, refugees, and migrants in the United States of America, 2015. 


\subsubsection{Equality and non-discrimination as the axis for all rights}

This normative prescription has great relevance, since it operates as an irradiating principle for the interpretation of rights, but it is also drawn as an instrumental guarantee for the application of other rights and even as an autonomous right. In the IACHR, it is found in almost all international instruments. Its application in migratory matters is vital, because although the right to equality is preached before the Law and discrimination is prohibited, as is the case with national origin, it is also permissible for States to make legitimate distinctions between nationals and foreigners, an aspect that is frequent in immigration policies.

The Inter-American Court has indicated that equality has entered the "domain of jus cogens" (IACHR, 2010: 248), which means that countries cannot tolerate behaviours that constitute discrimination. Several analyses of the rights of migrants arise, ranging from respect for the principle of equality and non-discrimination, such as the granting of nationality, judicial guarantees, to the application of the principle of non-refoulement. Despite this, in the case of Dominican and Haitian people expelled vs. Dominican Republic $^{27}$ (IACHR, 2014a), it says that States can have differentiated treatment between nationals and foreigners, as well as between documented and undocumented persons, provided they have objective motives that are reasonable and compatible with human rights (IACHR 2014a : para 403). This is frequent in the construction of migration policy and proposes the tension between sovereignty to establish limitations on the rights of foreigners and the emerging discussion about equality as a superior norm that is part of the ius cogens. To this end, the States have been invited to combat discriminatory practices at all levels and to adopt affirmative measures to guarantee equality of all persons submitted to their jurisdiction before the Law (IACHR, 2005: 155), which includes all migrants regardless of their legal status. This is because it seeks to ensure that there is no discriminatory treatment against certain categories of people and that progress is made towards a matching scheme between nationals and foreigners (Bosniak, 1991: 737).

\subsubsection{Expulsion of foreigners and the principle of non- refoulement: limitations on sovereignty}

The expulsion prohibition or return of foreigners is a guarantee constructed within the framework of the IACHR, both in the universal context ${ }^{28}$ and in the regional one ${ }^{29}$ and which has been influenced by the principle of "non refoulment" typical of International Refugee Law $^{30}$. It has developed from the application of the right to freedom of movement of foreigners within a State and is recognized in articles 22.8 and 22.9 of the ACHR.

Regarding the expulsion of foreigners ${ }^{31}$, the Inter-American Court emphasizes that the States are free to set entry and permanence requirements and that the expulsions

27 IACHR, Dominican and Haitian people expelled vs. Dominican Republic Series C, No. 282, 28 August 2014.

28 See, for example, article 13 of the Covenant on Civil and Political Rights and article 22 of the International Convention for the Protection of the Rights of all migrant workers and their families.

29 In the case of the European Human Rights Protection System, it is recognized in Article 4 of Protocol no. 4 and Protocol no. 7, Optional to the 1950 Rome Convention.

30 This guarantee originally arises in article 33 of the Geneva Convention on the Status of Refugees of 1951 .

31 Taking into consideration jurisprudence of provisional measures of Haitian and Dominican persons of Haitian origin, in OC-No. 18 of 2003, among others. apply 
authorized by the IACHR are those in which there is an individual analysis of each case, a due process and racial profiling is not produced ${ }^{32}$. The person's immigration history should be consulted, the nationality, the impact on the family breakdown due to the expulsion, the impact or disturbance in the life of the boy or the girl should be considered, and collective expulsions expedited without guarantees should be avoided ${ }^{33}$ (IACHR, 2014a). On the other hand, in migratory procedures, the purposes of the measures and the deprivation of liberty will have to be strictly distinguished and should only be used if necessary. Hence, immigration policies that involve compulsory detention are considered arbitrary, especially if they affect minors and involve expulsion (IACHR, 2014a: para 360).

The case of the Pacheco Tineo Family vs. the Plurinational State of Bolivia expands the scope of the prohibition by stating that the person may not be expelled or returned to their State of origin or to a third State, in case their right to life or liberty is in danger due to race, nationality, religion, social status, or political opinions (IACHR HR, 2013: 134), without any consideration for their immigration status, which shows a universal guarantee for every person. This pronouncement is based on what the ECHR has developed in this area (Salado, 2009:107), which limits the discretion of the States and which has been an underdeveloped aspect in the IACHR.

Individual expulsions may take place in cases when an individual proceeding is carried out with the characteristics already indicated, but it is a prohibition to perform them collectively, since in the opinion of the Inter-American Court, such decisions lack an objective analysis and are arbitrary (IACHR, 2012: 171).

\section{The Advisory Opinions: elements that integrate rights}

The advisory function of the Inter-American Court is classified as broad and unique in the IACHR, if a comparison is made with the universal and European systems (Salvioli, 2006: 5). Article 64 of the ACHR sets its scope with regard to legitimation, matters of interpretation and limitations (Nikken, 1999: 162). All American States members of the OAS, without having to be part of the ACHR, have the possibility of making consultations, as well as the specialized agencies of the OAS, which have competences in the area of human rights. With regard to the matters on which it can rule, it has determined that not only the norms emanating from the IACHR are within its competence, but also that it can have a say about any provision related to the protection of human rights of any treaty applicable to the American States, bilateral or multilateral in nature and that the OAS States may be party to them, including the reservations made and other instruments such as the DADH, and even on the compatibility of legislative projects of the States with the ACHR (Nikken, 1999: 166).

The value of the Advisory Opinions (AO) has been the subject of debate in the doctrine, since some maintain that they lack jurisdictional value (Faúndez, 1996: 450). However, there are those who affirm that the Inter-American Court is an autonomous judicial institution whose purpose is the application and interpretation of the ACHR, so its nature and decisions are jurisdictional in nature, which implies that it is an auxiliary

32 The provisions of Article 12 of the ICCPR and the provisions of OG No. 15 of the Human Rights Committee apply.

33 IACHR, Dominican and Haitian people expelled vs. Dominican Republic case, para. 379, and also IACHR, Vélez Loor Vs. Panama case, para. 146. 
jurisprudence of the IACHR and that it has been invoked in a large number of contentious cases (Nikken, 1999, 171), as happens in immigration.

To date, there have been three AO that refer to immigration or foreign persons' issues and they have been an evolutionary point for inter-American jurisprudence, since they establish a minimum standard of treatment regarding rights.

\subsection{Consular assistance as a nucleus for the exercise of rights}

AO-16 evidences the link between the right to information in the framework of consular assistance and the enjoyment of the rights inherent to the person according to the $\mathrm{ACHR}^{34}$ (IACHR, 1999). It analyses guarantees associated with due process and equal access to justice, and also says that states must eliminate as many barriers as possible to facilitate the right to effective defence through compensation measures in favour of vulnerable individuals, as with foreigners ${ }^{35}$. It should be kept in mind that such omission implies international responsibility from the State and creates the need to initiate a new process with due notice before the consular authority (Ortiz, 2013: 127). These considerations have been subject to pronouncement in contentious cases such as those already analysed, which show that it is necessary that migrants have effective consular attention from their States. Acosta Calderón vs. Ecuador (IACHR, 2005a: 125) and Tibi vs. Ecuador (IACHR, 2004: 112).

\subsection{The right to equality as an instrumental guarantee}

AO-18 of 2003 addresses three major issues; consideration of the principle of equality and non-discrimination as a "ius cogens" rule, recognition of some labour rights of undocumented persons and expulsion guarantees.

Regarding the first, the Inter-American Court concludes that the principle of equality and non-discrimination is a "jus cogens" rule on which all legal scaffolding of national and international public order rests (Hennebel, 2004: 747). It states: "Today, no legal act is admitted that conflicts with the said fundamental principle, discriminatory treatment is not allowed to the detriment of any person on grounds of gender, race, colour, language, religion or conviction, opinion political or other, national, ethnic or social origin, nationality, age, economic situation, property, marital status, birth or any other condition" (IACHR, 2003: 109).

Undocumented migrants must have decent treatment under the respect of certain minimum guarantees, because "the regular situation of a person in a State is not a necessary condition for that State to respect and guarantee the principle of equality and non-discrimination, since, as already mentioned, this principle is fundamental and all states must guarantee it to their citizens and to any foreign person in their territory" (IACHR, 2003: 113).

34 See IACHR, Right to Information on consular assistance within the framework of the guarantees of due legal process, para. 110 and following.

35 Ibid., para. 119. The Court indicated that: "(...) the real situation of foreigners who are subject to criminal proceedings, upon which their most valuable legal assets and, eventually, their very life (...) depend, must be taken into account. (...) The notification of the right to communicate with the consular representative of their country will contribute to considerably improve their defence possibilities (...)" (para. 120). 
What the Court said does not imply that a policy of open doors is given freeway (Chueca, 2005: 124), as countries may initiate actions against migrants who do not comply with the state legal system, it being legitimate to deal with documented and undocumented migrants differently. This provided that this differential treatment is reasonable, objective, proportional, and does not harm human rights (IACHR, 2003: paras 118 and 119).

Judgements on the importance of equality and the prohibition of discrimination have been a recurring theme, which, together with vulnerability, have characterized the decisions of contentious cases concerning migrants (IACHR, 2010: 248), (IACHR, 2014a), (IACHR, 2005: 155) and demonstrate the importance of evolving towards a path of equalization of rights in favour of the recognition of the dignity of the person, without the States completely losing their discretionary power to determine the contours of their immigration policy.

Regarding the rights derived from the labour relationship, the Inter-American Court again mentions human dignity and its importance for the rights of migrant workers. It states that the enjoyment of fundamental labour rights guarantees workers and their families a decent life. Workers have the right to perform a work activity in adequate and fair conditions and receive remuneration that allows them and their family members to enjoy an adequate standard of living compatible with dignity (IACHR, 2003: para 157).

This allows us to maintain that the Inter-American Human Rights System has made significant contributions in the difficult equality route between nationals and foreigners, and they have been worthy of being called "the certificate of quality in the field of human rights" (Chueca, 2005b: 61).

It should be noted that in this $\mathrm{AO}-18$, the Inter-American Court interprets provisions contained in the Universal Declaration of Human Rights, (UDHR) (UN, 1948) and ICCPR, requested in the consultation, and declares its competence in pointing out that they are international instruments on human rights and bind the consulting State (IACHR, 2003: para. 55). Although the consultation does not ask about aspects related to the International Convention on the protection of the rights of all migrant workers and their families (CRMW) (UN, 1990), the Court invokes this treaty because it considers it of vital importance for the development of the Convention (IACHR, 2003: paras. 69, 70, 75, 86, $128,131)$

\subsection{Good practices for the protection of migrant children}

AO No. 21 of 2014 addresses the rights of children and its main contribution is to recommend good practices to the States throughout the migration process. To this end, the Court refers to the importance of interpreting the American Declaration of Rights and Duties of Man, as well as its own jurisprudence ${ }^{36}$, the Convention on the Rights of the Child (CRC) (UN, 1989) and the OG of the $C^{37}$ (UN, 2005), considering them "opinio iuris comunis" regarding the protection of children's rights and contributing decisively to the interpretation of the ACHR (IACHR, 2014: 57). In addition, this AO also uses the

36 Dominican people of Haiti and Haitian origin vs. Dominican Republic case.

37 Committee on the Rights of the Child, OG-6/05, Treatment of unaccompanied children and separated from their family outside their country of origin, 39 period sessions, 2005, Doc. CRC/GC/2005/6, 1 September 2005. 
interpretation of the rules applicable to migrants in order to complete the necessary framework that provides protection to these persons with multiple vulnerability factors and to determine the scope of the obligations of the States.

It warns that the scope of protection derived from the ACHR and other treaties will be extended to every child, regardless of migration status, including refugees, migrants, asylum seekers and stateless persons (IACHR, 2014b: para 95).

Within the main defined obligations, States must adapt their regulations based on the application of the principle of useful effect (Sagüés, 2010: 118) for the enjoyment of rights in the context of migration. Hence the importance of procedures that States must take into account in the face of the risks that unaccompanied minors or separated from their families may suffer (victims of trafficking, sexual exploitation, participation in criminal activities or labour exploitation). To this end, it is necessary to have mechanisms for early detection of children in situations of migratory vulnerability (IACHR, 2014b: paras 90 and 93).

AO-21 points out the procedures to identify the international protection needs of migrant children such as the granting of asylum and shelter, no deprivation of the freedom of children regardless of their immigration status, creation of priority measures for the protection of minors, accommodation special conditions (IACHR, 2014b: para 106), respect for the principle of non-refoulement (IACHR, 2014b: para 207), and respect for family life (IACHR, 2014b: para 263). Under this approach, the United Nations Human Rights Council issued a report on the global problem of unaccompanied migrant children and adolescents and human rights, which highlights the good practices proposed by the IACHR in this area (United Nations General Assembly, 2017).

The foregoing allows us to maintain that the Inter-American Court does not seek to ignore the sovereignty of the States. Still, they must adapt their legislation to international treaties and develop a series of good practices in immigration matters, including: privilege the human rights approach, promptly identify minors at risk, respect due process, the right of children to personal liberty and return procedures may not at any time endanger the life or integrity of minors.

In this ruling, the Inter-American Court has resumed the considerations already made in contentious cases that have failed, in which the rights of children, the double vulnerability of minors and the protection of the family are the guiding axes of the decision, as happened in cases already analysed in contentious jurisprudence (IACHR, 2014a), (IACHR, 2005). According to the inter-American jurisprudence in this matter, the beginning of a new stage in the integral protection of the rights of children could be considered (Beloff, 2009: 17), since it sees minors in migratory status as a special protection objective within the IACHR.

\section{Conclusions}

The aforementioned jurisprudence shows that for the Inter-American Court, the issue of the rights of foreigners and immigrants has been of recent treatment, as in their decisions they have not been a cross-cutting issue addressed over the years. Despite this, it is possible to identify some contributions to the IACHR that have been produced thanks to the permanent dialogue between contentious decisions and the exercise of the advisory function. This is because in the latter, the Inter-American Court has been able to integrate 
in the framework of foreigners' rights interpretation parameters from the universal system that reinforce compliance with the obligations arising from the inter-American framework. This is the case of the application of the standards set by the CRC that have been inspiring to provide better protection for the rights of migrant children and people in need of international protection.

On the other hand, it is worth noting that the rulings of the jurisprudence regarding migrant workers have risen to a higher standard, the principle of equality and nondiscrimination, which is vital for countries to move towards recognition of the rights of these people under optimal parameters of dignity. Although there have not yet been contentious decisions regarding the rights of migrant workers, it is possible that the impact of AO-18 may favour the protection framework in this area.

The existing judgments, to a large extent, have addressed the protection of the rights regarding legal personality, name, nationality, prohibition of expulsion and requirements for it, as well as the application of the principle of equality and non-discrimination, labour rights, and derived benefits of the employment contract, regardless of the legal status of the immigrant. Likewise, it has studied issues such as guarantees in conditions of detention, children's rights and, more recently, it has recommended strict care protocols for unaccompanied minor migrants or those separated from their families. In this way, the rights of migrant workers and migrant children have set the guidelines for what can be considered an evolutionary development of jurisprudence in this area, giving rise to what may later be a corpus iuris in matters of migrants' rights.

The protection of these rights through the interpretation of the Inter-American Court constitutes a limitation to the sovereign power of the States, since in contentious cases it has imposed sanctions and reparation measures that must be accepted by the States; on the other hand, in the case of advisory opinions, they have set parameters for the interpretation of the norms that may well be assumed by the States in order to comply with the obligations derived from the treaties without implying a condemnation, that is to say, a construction of a favourable legal framework for migrants with a highly constructive sense.

Accordingly, it is necessary to have rulings with differential approaches in favour of migrant women and girls, as well as older adults, people with disabilities, LGBTI population and other differentiated groups, given that such issues have not yet been addressed. Also, taking into account that the legitimacy for the formulation of the consultations allows some bodies of the IACHR resort to interpretation, it would be appropriate that, for example, the Inter-American Commission of Women, the American Indian Institute and the Inter-American Children's Institute, could activate authority in order to achieve other rulings in these respect and achieve greater progress in the protection of rights.

Finally, in the decisions analysed by the Inter-American Court, elements of the advisory jurisprudence that have been used for the resolution of matters in contentious situations are found, as well as some axes for decision making in favour of the rights of migrants, including the concept of vulnerability, human dignity, equality and non-discrimination.

\section{References}

Asamblea General Naciones Unidas. (2017). "El problema mundial de los niños y 
adolescentes migrantes no acompañados y los derechos humanos". In Informe Final Del Comité Asesor Del Consejo de Derechos Humanos, 1-12. Retrieved from http://www.refworld.org/cgi-

bin/texis/vtx/rwmain/opendocpdf.pdf?reldoc=y\&docid=59cb96b94

Arlettaz, F. (2015). "La nacionalidad en el derecho internacional americano". In Anuario Mexicano de Derecho Internacional, (XV), 413-447. Retrieved from http://www.scielo.org.mx/pdf/amdi/v15/v15a11.pdf

Beloff, M. (2009). Los derechos del niño en el sistema interamericano, Buenos Aires:Editores del Puerto.

Bosniak, L. S. (1991). "Human rights, state sovereignty and the protection of undocumented migrants under the". In International Migration Review, 25(4), 737-770. Retrieved from http://www.jstor.org/stable/2546843\%5Cnhttp://www.jstor.org/page/info/about/polici es/terms.jsp

Carrillo, J. A. (2001). Soberanía de los Estados y Derechos Humanos en Derecho Internacional Contemporáneo. Madrid: Tecnos.

Chueca, A. (2005a). "La Convención sobre la protección de los Derechos de todos los Trabajadores Migratorios y de sus Familiares". In Revista de Derecho Migratorio Y Extranjería, (10), 117-126.

Chueca, A. (2005b). "Un análisis de las migraciones internacionales a través de cinco mitos". In Revista de Derecho Migratorio y Extranjería, (9), 45-63.

Consejo de Europa. (1963) Protocolo No.4 adicional al Convenio Europep de los Derechos Humanos y las Libertades Fundamentales, Estrasburgo, 16.IX, Retrieved from https://www.echr.coe.int/Documents/Convention_SPA.pdf

Consejo de Europa. (1984) Protocolo No.7 adicional al Convenio Europep de los Derechos Humanos y las Libertades Fundamentales, Estrasburgo,22XI, Retrieved from https://www.echr.coe.int/Documents/Convention_SPA.pdf

Corte IDH. (1984). Opinión Consultiva OC-4/84 del 19 de enero de 1984, Propuesta de modificación a la Constitución Política de Costa Rica relacionada con la naturalización. Retrieved from https://www.cejil.org/sites/default/files/i._opiniones_consultivas_de_la_corte_interame ricana_de_derechos_humanos.pdf

Corte IDH. (1999). Opinión consultiva OC-16/99 del 1 de octubre de 1999, El derecho a la información sobre la asistencia consular en el marco de las garantías del debido proceso legal. Retrieved from http://www.acnur.org/fileadmin/scripts/doc.php?file=fileadmin/Documentos/BDL/2001/ 0102

Corte IDH. (2001). Caso Ivcher Bronstein vs. Perú. sentencia de 6 de febrero de 2001. Retrieved from http://www.corteidh.or.cr/docs/casos/articulos/Seriec_74_esp.pdf

Corte IDH. (2003). Opinión Consultiva Oc-18/03 de 17, de Septiembre De 2003, Condición jurídica y derechos de los migrantes indocumentados, 127. Retrieved from http://www.acnur.org/t3/fileadmin/Documentos/BDL/2003/2351.pdf?view=1

Corte IDH. (2004). Caso Tibi vs. Ecuador. Sentencia de 7 de septiembre de 2004. 
Retrieved from http://www.corteidh.or.cr/docs/casos/articulos/seriec_114_esp.pdf Corte IDH. (2005). Caso de las niñas Yean y Bosico vs. República Dominicana. Sentencia, de 8 de septiembre de 2005. Retrieved from http://www.corteidh.or.cr/docs/casos/articulos/seriec_130_esp.pdf

Corte IDH. (2005 a). Caso Acosta Calderón vs. Ecuador. Sentencia de 25 de junio de 2005-129, Retrieved

from

http://www.corteidh.or.cr/docs/casos/articulos/seriec_129_esp1.pdf

Corte IDH. (2010). Caso Vélez Loor Vs. Panamá. Sentencia de 23 de noviembre de 2010, $1-100$. Retrieved

from http://www.acnur.org/t3/fileadmin/Documentos/BDL/2010/8140.pdf?view=1

Corte IDH (2012). Caso Ndege Dorzema y otros vs. República Dominicana. Sentencia de 24 de octubre de 2012-251. Retrieved from http://www.corteidh.or.cr/docs/casos/articulos/seriec_251_esp.pdf

Corte IDH (2013). Caso familia Pacheco Tineo vs. Estado plurinacional de Bolivia, Sentencia de 25 de novimebre de 2013, Retrieved from http://www.corteidh.or.cr/CF/jurisprudencia2/ficha_tecnica.cfm?nId_Ficha=376

Corte IDH. (2014a). Caso Personas dominicanas y haitianas expulsadas vs. República Dominicana. Sentencia de 28 de agosto de 2014. Retrieved from http://corteidh.or.cr/docs/casos/articulos/seriec_282_esp.pdf

Corte IDH. (2014b). Opinión consultiva oc-21/14 de 19 de agosto de 2014 Derechos y garantías de niñas y niños en el contexto de la migración y/o en necesidad de protección internacional. Retrieved from http://www.iin.oea.org/pdf-inn/Opinion-Consultiva-19agosto2014.pdf

Corte IDH. (2015). "Refugiados y migrantes en estados unidos familias y niños no acompañados". Organización de Los Estados Americanos. Retrieved from https://www.oas.org/es/cidh/informes/pdfs/Refugiados-Migrantes-EEUU.pdf

Corte IDH (2017). Cuadernillo de jurisprudencia de la Corte Interamericana de Derechos Humanos, personas en situación de migración y refugio. (2), Retrieved from http://www.corteidh.or.cr/publicaciones.html

Faúndez, H. (1996) El Sistema Interamericano de Protección de Derechos Humanos: aspectos institucionales y procesales. Instituto Interamericano de Derechos Humanos, Costa Rica.

Gozaíni, O. (2006). Incidencia de la jurisprudencia de la Corte Internamericana de Derechos Humanos en el Derecho Interno, Estudios constitucionales, (2), 335-362, Retrieved from http://www.pensamientopenal.com.ar/system/files/2018/08/doctrina46919.pdf

Gros, H. (1996). Análisis jurídico comparativo de las legislaciones sobre asilo en América Latina y los instrumentos internacionales y regionales (Estudios Básicos de Derechos Humanos, V), Instituto Interamericano de Derechos Humanos, 210-225, Retrieved from http://www.corteidh.or.cr/tablas/a12007.pdf

Hennebel, L. (2004). "I'humanisation du droit international des droits de I'homme: commentaire sur l'avis consultatif no. 18 de la cour interaméricaine relatif aux droits des travailleurs migrants (the humanization of international human rights law: observations 
under the inte)". In Revue Trimestrielle Des Droits Del L'homme, 59, 747. Retrieved from https://papers.ssrn.com/sol3/papers.cfm?abstract_id=1964939

Nikken, P. (1999). "La función consultiva de la Corte Interamericana de Derechos Humanos". In Biblioteca jurídica virtual del Instituto de Investigaciones Jurídicas de la UNAM, 161-180, Retrieved from https://archivos.juridicas.unam.mx/www/bjv/libros/5/2454/10.pdf

Nuñez, C. (2018). "La Jurisprudencia de la Corte Interamericana de Derechos Humanos frente a la movilidad humana: entre cosmopolistismo y hospitalidad". In Universitas,(27), 76-109, Retieved from https://e-revistas.uc3m.es/index.php/UNIV/article/view/4019

OEA (1948). "Carta de la Organización de Estados Americanos". In Novena Conferencia Internacional

Americana,

http://www.oas.org/es/sla/ddi/docs/tratados_multilaterales_interamericanos_A-

41_carta_OEA.pdf

OEA. (1948 A). "Declaración Americana de los Derechos y Deberes del Hombre". In Novena Conferencia Internacional Americana, 6. https://doi.org/10.1017/CB09781107415324.004

OEA. (1969). "Convención Americana sobre Derechos Humanos o Pacto de San José de Costa Rica". In Tratados Multilaterales Interamericanos, 24. Retrieved from http://www.oas.org/dil/esp/tratados_B-

32_Convencion_Americana_sobre_Derechos_Humanos.pdf

OEA. (2009). Reglamento de la Corte Interamericana de Derechos Humanos. Retrieved from http://www.corteidh.or.cr/sitios/reglamento/nov_2009_esp.pdf

ONU. (1948). Declaración Universal de Derechos Humanos, Retrieved from https://www.un.org/es/universal-declaration-human-rights/index.html

ONU. (1951). Convención sobre el Estatuto de los Refugiados, Retrieved from https://www.acnur.org/5b0766944.pdf

ONU. (1965). Convención internacional sobre la eliminación de todas las formas de discriminación racial, Retrieved from http://www.ohchr.org/SP/ProfessionalInterest/Pages/CERD.aspx

ONU. (1966). Pacto internacional de derechos civiles y políticos. Retrieved from http://www.ohchr.org/SP/ProfessionalInterest/Pages/CCPR.aspx

ONU. (1990). Convención internacional sobre la protección de los derechos de todos los trabajadores migratorios $y$ de sus familiares. Retieved from https://www.ohchr.org/sp/professionalinterest/pages/cmw.aspx

ONU. (1993). "Declaración y Programa de Acción de Viena". In Revista Internacional de La Cruz Roja, 18(118), 351. https://doi.org/10.1017/S0250569X00017015

ONU. (2005). "Convención sobre los derechos del niño trato de los menores no acompañados y separados de su familia fuera de su país de origen". In Comité de Los $\begin{array}{lllll}\text { Derechos Del Niño. } & \text { Retrieved }\end{array}$ http://poscla.org/libros/adultos/Convencion_derechos_nino.pdf

Olea, E.M. (2015). "Migración (en la jurisprudencia de la Corte Interamericana de Derechos Humanos)". In Economía. Revista en cultura de la legalidad.(9), 249-272. 
Retrieved

from

https://e-

revistas.uc3m.es/index.php/EUNOM/article/viewFile/2826/1522

Olmos. B. (2017). "Assesing the evolution of the Inter-American Court of Human Rights in the protection of migrants 'rights: past, present and future". In International Journal of Human Rights, Retrieved from http://dx.doi.org/10.1080/13642987.2017.1348736

Ortiz, L. (2013). Derechos humanos de los indocumentados. Valencia: Tirant Lo Blanch.

Ovalle, J.(2012). "La influencia de la jurisprudencia de la Corte Interamericana de Derechos Humanos en el derecho interno de los estados latinoamericanos". In Boletín mexicano de Derecho Comparado, (134)XLV, 595-623, Retrieved from http://www.scielo.org.mx/pdf/bmdc/v45n134/v45n134a5.pdf

Palacios, M. T. (2012). "La aplicación del principio de igualdad y no discriminación a los trabajadores migratorios". In Civilizar Ciencias Sociales Y Humanas, (12), 77-92. Retrieved from http://www.scielo.org.co/pdf/ccso/v12n22/v12n22a0.pdf

Quispe, F. (2016). "La protección de los derechos humanos en el sistema interamericano: su evolución y una visión actual". In Anuario Español de Derecho Internacional, (32), pp.225-258, DOI: 10.15581/010.32.225-258. Retrieved from https://earchivo.uc3m.es/bitstream/handle/10016/26589/proteccion_quispe_AEDI_2016.pdf?se quence $=3 \&$ isAllowed $=y$

Roa, J.E. (2015). La función consultiva de la Corte Interamericana de Derechos Humanos, Temas de Derecho Público, No. 94. Bogotá: Universidad Externado de Colombia.

Salado A.M. (2009). Los tratos prohibidos en el artículo 3 del Convenio Europeo de Derechos Humanos, (La Europa de los derechos: el Convenio Europeo de Derechos Humanos). Centro de Estudios Políticos y Constitucionales, Madrid.

Sagüés, N. (2010). "Obligaciones Internacionales y control de convencionalidad". In Estudios constitucionales, 8 (1), 117-136, https://dx.doi.org/10.4067/S071852002010000100005

Ventura, M.E y Zovato, D. (1989). La función consultiva de la Corte Interamericana de Derechos Humanos: naturaleza y principio. Instituto Interamericano de Derchos Humanos. Madrid: Civitas 


\section{BETWEEN FREEDOM OF CONTRACT AND THE PRINCIPLE OF GOOD FAITH: AN INSIDE VIEW ON THE REFORM OF PRIVATE LAW OF KAZAKHSTAN}

\section{Kamal K. Sabirov}

sabirov.k@gmail.com

PhD student in Legal Sciences at L.N. Gumilyov Eurasian National University and Senior Researcher at the Institute of Legislation of the Republic of Kazakhstan. He is the author of more than 40 scientific articles in Kazakh and Russian languages in the field of private law issues and active participant of the law making process in Kazakhstan.

Venera T. Konussova konussova@mail.ru Deputy Director of the Institute of Legislation of the Republic of Kazakhstan; PhD in Legal Sciences. She is one of the developers of the Enterprise Code of the Republic of Kazakhstan and one of the authors of the Kazakhstan's law on advocacy.

Marat A. Alenov Iscc@mail.ru

Doctor of Law, Professor at L.N. Gumilyov Eurasian National University. He is one of the lead experts in Civil Procedure in Kazakhstan. He is the author of a large number of works in the field of private law and civil procedure.

\section{Abstract}

Over the years since Kazakhstan gained independence there have been cardinal changes in the country's economy associated with the inflow of foreign investments. These changes require the implementation of foreign experience in regulating economic relations and in particularly foreign contractual institutions. The International Financial Center "Astana" has started functioning in Kazakhstan since 2018. The acts of the International Financial Center are based on the principles and norms of law of England and Wales. In this regard, a largescale reform of the private law of the Republic of Kazakhstan was launched, aimed at identifying a number of civil-law ideas and designs that can be measured out in the Kazakh legislation from English law. The authors of this research are direct participants of the reform. This study is aimed at highlighting one of the issues considered within the framework of the reform of private law: strengthening the role of the principle of freedom of contract and the principle of good faith in the contract law of the Republic of Kazakhstan.

\section{Keywords}

Principle of good faith; freedom of contract; bona fide purchaser; legislation of Kazakhstan; private law of Kazakhstan

\section{How to cite this article}

Sabirov, Kamal K., Konussova, Venera T.; Alenov, Marat A. (2019). "Between freedom of contract and the principle of good faith: an inside view on the reform of private law of Kazakhstan". JANUS. NET e-journal of International Relations, Vol. 10, N. ${ }^{2}$ 2, November 2019April 2020. Consulted [online] on the date of the last visit, https://doi.org/10.26619/1647$\underline{7251.10 .2 .10}$ 


\section{BETWEEN FREEDOM OF CONTRACT AND THE PRINCIPLE OF GOOD FAITH: AN INSIDE VIEW ON THE REFORM OF PRIVATE LAW OF KAZAKHSTAN}

Kamal K. Sabirov

Venera T. Konussova

Marat A. Alenov

\section{Introduction}

Despite the fact that the legal system of the Republic of Kazakhstan is the part of the Civil law, it was formed under the influence of the Soviet legal system and inherited many elements from it. The private law of the Republic of Kazakhstan is much like Russian private law. This is not surprising because both systems of private law are based on the model code of the CIS countries and also had a common history of formation within the framework of Soviet civil law. Nevertheless, more than 27 years have passed since the collapse of the Soviet Union and the private law of the CIS countries has altered appreciably (Akyn and Rakhymbai, 2017).

The reform of civil legislation has been ongoing for several years in the Russian Federation. A number of legislative acts were adopted to amend the Civil Code of the Russian Federation; in particular the obligation law was reformed. In the course of this reform some legal institutions of common law were implemented.

The International Financial Center "Astana" has started functioning in the Republic of Kazakhstan since 2018. The court of the International Financial Center relies on English contract law, in this connection it can be stated that the process of implementation of elements of common law into the legal system of the Republic of Kazakhstan is objective.

In connection with the beginning of the activity of the International Financial Center a large-scale reform of the legislation on the implementation of certain provisions of English and European law is under way. The participants of this reform are the authors of this article. At present, the Ministry of Justice developed a draft Concept for the future bill, which immediately aroused maximum discussion in the scientific and legal community (Konussova and Nesterova, 2016).

The purpose of the reform of civil legislation in the Republic of Kazakhstan is the modernization and development of private law. In this regard, it was necessary to compare approaches to the regulation of similar institutions, understand the legal logic and identify points of contact with it. And only on this basis to deny or to accept innovations that common law brings to the development of continental law. 
Due to the fact that the civil legislation of the Republic of Kazakhstan and the Russian Federation are largely similar, considerable attention was paid to the Russian experience. But according to the respective Kazakh legal scientists, not all the ideas embodied in the course of the reform of Russian private law can be considered as successful (Sulejmenov, 2016).

The reform of private law in the Russian Federation was confronted with conflicting opinions between supporters of English contract law and adherents of the classical German law school. Ultimately, during the reform an attempt to find a compromise, and amendments of both sides were taken into account.

During the preparation of the draft law various issues were raised, including the strengthening of the role of judicial practice, the development of the principle of good faith and the principle of freedom of contract, the introduction of the concept of "corporation" and legislative regulation of corporate relations, the development of holding legislation, the implementation of individual institutions of contract law (estoppel, liquidated damages, representations and warranties, indemnity clause, etc.). Thus, the reform envisaged quite revolutionary changes in the current legislation, which logically provoked resistance from conservative lawyers. In the end, some of the proposed innovations of the project had to be abandoned.

Within the framework of this article, it is proposed to discuss one of the elements of the reform of private law in the Republic of Kazakhstan, namely, the expansion of freedom of contract and as a counterbalance the strengthening of the principle of good faith.

Generally, in contract law there are two fundamental principles coexisting: the principle of freedom of contract and the principle of good faith in performance of the contract. And if English law more attention is paid to the principle of freedom of contract, in continental law the principle of good faith can be considered as a fundamental principle.

The freedom-of-contract doctrine implies that the parties of the contract have exactly the same obligations as those provided in their contract. The principle of good faith suggests that the parties of the contract have in front of each other a whole range of other obligations that arise not from the contract but from the requirement to act in good faith, as it is understood by this law and order. The principle of good faith can also exempt a party from the performance of its contract obligations if this rule of law considers it fair in this situation. Also, relying on the concerned principle the court can assign the responsibilities to the party that were not prescribed in the contract. All this contradicts the principle of freedom of the contract.

As a part of the ongoing reform of private law in Kazakhstan, there was an attempt to find a compromise between the principle of good faith and freedom of contract.

\section{Research Methods}

We undertook an analysis of existing legal norms, as well as the content of research materials of Kazakh, Russian, English, American and German specialists in the field of private law with the purpose of comprehensive analysis of some issues of the reform of private law of the Republic of Kazakhstan. During the research were used the works of both Kazakh and foreign authors - representatives of the German and English law 
schools. The methodological basis of the study includes: system analysis, comparison, theoretical and legal forecasting.

\section{Main results and discussion}

\section{Expanding The Limits Of Freedom Of Contract}

The historical roots of the principle of freedom of contract can be traced back to the Roman law that gave great priority to the free expression of the will of a person and denied any extraneous pressure. The principle of freedom of contract reached its peak in the middle of the nineteenth century after that it began to increasingly restrict itself to various legal orders.

In the United States freedom of contract is recognized as one of the constitutional rights of a citizen. The Supreme Court confirmed the strengthening of this right in the case of Frisbie v. United States, 157 U.S. 160 [1895] (Bernstein, D., 2008).

In general, we can distinguish three basic elements of freedom of contract: the freedom to conclude a contract, the freedom to choose a contract and the freedom to determine the content of the contract.

Here is how these elements are described in the comments to the Civil Code of the Republic of Kazakhstan: "Any person, at his own discretion and under no coercion from the outside, has the right: a) to decide whether to enter into or not to enter into a contract; b) to elect a partner who wish to conclude a contract; c) to determine the terms of the contract".

Controversial are the contracts which although not explicitly prohibited by law can be considered unethical or immoral. For example such contracts are the contracts on transplantation of human organs, which cause controversy among their supporters and opponents (Trebilcock, 1993). It is also necessary to touch on the issue of limiting the principle of freedom of contract. There are separate cases of restriction of freedom of contract even in English law. To such Craswell includes rules against liquated damages and rules that prohibits the enforcement of promises unsupported by consideration (Craswell, 1995).

The civil legislation of the Republic of Kazakhstan in paragraph 4 of Article 8 of the Civil Code of the Republic of Kazakhstan establishes general requirements for the behavior of citizens and legal entities. These evaluative concepts make it possible to establish general limits of the contract, limiting the parties from abuse.

In addition, the operation of the principle of freedom of contract has certain exceptions, assigned in legislative norms. Article 380 of the Civil Code of the Republic of Kazakhstan prohibits compulsion to conclude a contract, while clarifying that this does not apply to cases where the obligation to conclude a contract is provided for by the legislation or a voluntarily accepted obligation.

The principle of freedom of contract plays a key role in the development of economy and market relations. In the opinion of A. Didenko the contract serves as an instrument for "democratization" of the economy and through it the society (Didenko, 2000). The principle of freedom of contract is a logical continuation of the rights and freedoms guaranteed by the Constitution of the Republic of Kazakhstan from this point of view. 
As it follows from the Constitutional provisions in respect of the realization of the rights and freedoms of the citizens, a discretion method of regulating legislation is used, permitting what is not directly prohibited by the laws. The principle of discretion in relation to the realization by man of his rights and freedoms is assigned in the Article 29.2 of the Universal Declaration of Human and Civil Rights and Freedoms, which states that "everyone shall be subjected only such limitations that are determined by law solely for the purpose of securing due recognition and respect for the rights and freedoms of others".

Nevertheless, despite these rules the civil legislation of the Republic of Kazakhstan presupposes the mandatory nature of rules of contract law. Discretion of norms is presumed only if there is a special clause in it "unless otherwise provided by the agreement of the parties". The rules that don't have such clause are considered as mandatory.

On the other hand, we note that there are mandatory norms that underline their imperative nature with a special clause in the civil law. Currently, judicial practice shows that in disputable issues the issue of determining the nature of the norm is decided by the court.

In this regard, it seems natural to expand the principle of freedom of contract to improve the business environment. At the same time it is necessary to develop the natural limitations of the principle of freedom of contract through the principle of good faith.

Basin noted that the principles laid down in the civil legislation of the Republic of Kazakhstan are directly opposed to those basic principles on which the previous Civil Code of the Kazakh SSR was built (Basin, 2003). The soviet law proceeded from the fact that it is possible to do only what is permitted by the law. All this suggests that the discretionary norms of the contract law should be presented in the civil law in a larger extent than the mandatory norms. However, as pointed out by Klimkin, contract law, where the principle of freedom of contract should "work" fully, consists of mandatory norms for almost of $90 \%$ (Klimkin, 2014).

Thus, the civil legislation of the Republic of Kazakhstan proceeds from an approach that presupposes the mandatory norms if the norm does not directly establish its mandatory nature. In other words, "everything that is not permitted by law is prohibited". This restriction does not comply with the basic principles of the civil law; rights and freedoms guaranteed by the Constitution, as well as worldwide practice and it requires the changes.

In order to work out the best option for expanding the limits of freedom of contract, it is necessary to consider existing ways of limiting this principle. In the opinion of $\mathrm{S}$. V. Scriabin there are two main trends in the restriction of contractual freedom. The first implies the inclusion in civil law special clauses, for example, indicating the need to exercise civil rights in good faith, reasonably and fairly (Clause 4, Article 8 of the Civil Code of the Republic of Kazakhstan). The second implies the strengthening in the law of mandatory rules regarding the conditions of the certain types of contracts (Scriabin, 2003).

Analysis of civil legislation of the Republic of Kazakhstan shows the application of both ways of restricting freedom of contract. Restriction of freedom of contract by means of general reservations is typical for the norms on disputable transactions, and restriction of freedom of contract by direct restrictions for the rules on null transactions. 


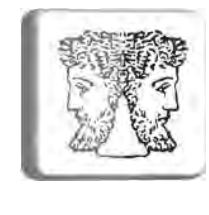

Based on the above, we believe that the extension of the principle of freedom of contract should not come from the idea of eliminating the existing limitations of the principle of freedom of contract, but from the strengthening of permissive beginnings in legislation.

Summarizing, the principle of freedom of contract is currently a fundamental principle of civil legislation. Nevertheless, in order to ensure the full protection of this principle in business transaction, it is necessary to significantly clarify the norms of civil legislation for strengthening the freedom of contract.

First, it is necessary to add to article 2 of the Civil Code of the Republic of Kazakhstan clarification that the freedom of contract is indeed the principle of civil law. Secondly, the protection of the principle of freedom of contract can be achieved by strengthening the discretion nature of the civil law.

The introduction of appropriate changes will significantly improve the civil legislation of the Republic of Kazakhstan and make it friendlier for the business environment.

\section{Strengthening The Principle Of Good Faith}

An indication of the requirements of good faith, justice and reasonableness appeared in the continental law under the influence of the French revolution which took the ideas of individual freedom, equality before the law and justice. These principles contributed to the development of social relations, ideas about the free expression of the will of the individual on the basis of contracts concluded with other persons. Almost all the systems of law of countries that identify themselves with the Civil law contain one or more provisions on good faith (Mackaay, 2011).

The principle of good faith also plays a central role in the law of mixed type (based on both common and civil law). For example, in the state of Louisiana the principle of good faith is applied in the law on general and conventional obligations, commercial law, family law, property law, etc. (Lovett, 2018).

There is practically no single definition of the concept of good faith in the law. But nevertheless this principle plays an important role, especially in the contract law (Podshivalov, 2018).

In the common law each contract implies the existence of good faith in its interpretation and enforcement. At the same time good faith is perceived as the absence of bad faith. In continental law good faith is observed as a category of morality and as a requirement that walks the line in the behavior.

The principle of good faith has a key role in the German law. German courts feel entitled and even obliged to interfere in the contractual relations when these relations are unfair to one of the parties. As for France, the principle of good faith in the contract relations was present in it since the Code of Napoleon.

In our opinion, the importance of the principle of good faith proved by the UK experience, where it has been unrecognized for a long period of time. As Mackaay notes, it was the English lawyers who resisted this doctrine most of all. Unlike the US law, where good faith is recognized in the pre-contractual legal relations, English law has treated this institution critically (Mackaay, 2011). For example, the right of the court to challenge the terms of the consumer contract ex post under the aegis of the fight against unfair contract terms was recognized in England only in the early 1990s and then only under the pressure 
of obligations to the EU. This followed by a lively discussion among European and British lawyers about how much economic integrity should prevail over cultural and national identity (Collins, 1994).

Let us cite a few positions of the English courts of the early 1990s that regulate the question of applying to the principle of good faith:

"There is no general doctrine of good faith in English law of contract.
The injured parties are free to act as they wish, provided that they
do not act in breach of the term of the contract" (JamesSpencer\&Co
Ltd. v. Tame Valley Padding Co Ltd. [1998]).

"The duty to negotiate in good faith is unworkable in practice" (Walford v. Miles [1992]).

In these cases, the court preferred the application of the principle of freedom of contract and judicial competition. This was the principal position of English law, which elevated the freedom of contract to the fundamental principle of the contract law for a long time. Meanwhile it is obvious to lawyers of the civil law tradition that the absolute freedom of the contract contradicts the fair consideration of the case.

However, the position of English courts in recent years has changed markedly. In the case of Yam Seng PTE Ltd v International Trade Corporation (ITC) Ltd. [2013], the court has spoken on the principle of good faith, recognizing that the traditional positions of English law regarding good faith is unreasonable (Poole, 2012).

"Good faith" in the US law was finally normatively defined in the codification in the Uniform Commercial Code (U.C.C.). In this document, an objective approach to determining honesty was applied to the definition of this concept. So it's a general concept that can be compared not only with the principle of good faith in Roman-German law, but also with evaluative concepts of rationality, justice and business ethics.

All this points to the importance of the principle of good faith.

The principle of good faith sum up business contracts, both in continental and common law. For example, paragraph 4 of Article 8 of the Civil Code of the Republic of Kazakhstan states that "good faith, reasonableness and fairness of actions of participants of legal relations are assumed". Thus, good faith is implied in each contract concluded, as well as the actions of the business entity. The principle of good faith is aimed at the formation of a model behavior, based on the prevailing in the society ideas about the honest image of thoughts, respect for the fair interests of others, the permissible degree of selfishness in legal behavior (Mikryukov, 2013). If we overview the principle of good faith from this perspective, it becomes clear that good faith underlies almost all private law and it is a general principle of the private law.

In the civil legislation of the Republic of Kazakhstan good faith is used in two meanings: objective and subjective. It's a traditional position of German legal doctrine which emphasizes good faith in the subjective meaning "guter Glauben" and in the objective meaning "Treu und Glauben" (Wieacker, 1956). 


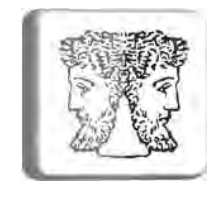

In an objective meaning good faith is understood as a "good conscience" i.e. a moral and ethical category and a principle of civil law based on moral and ethical beginnings. In the subjective meaning good faith is understood as a concrete, subjective state of a person and its compliance with certain criteria based on the moral ethical principle of good faith.

Also the reasonableness and fairness of actions of participants of civil legal relations are supposed according to paragraph 4 of Article 8 of the Civil Code of the Republic of Kazakhstan good faith. This norm marks good faith as a presumption.

It should also be taken into account that the category of good faith has a moral and ethical content. Therefore, in the civil legislation of the Republic of Kazakhstan there is no definition of the concept of "good faith" as in the case of such a definition, good faith could not be used as a moral assessment of the issue of protection of civil rights.

However, the question remains unresolved of whether it is possible to consider the requirements of good faith mentioned in the paragraph 4 of Article 8 of the Civil Code of Kazakhstan as a principle of the law. At the same time, good faith in the civil legislation of the Republic of Kazakhstan was not elevated to the category of the basic principles of civil law mentioned in the Article 2 of the Civil Code of the Republic of Kazakhstan. This causes a number of issues in the law enforcement practice.

Nevertheless, specification of the term "principle" in the text of the Civil Code of the Republic of Kazakhstan in relation to the requirements of good faith could remove most of the questions regarding the content of the basic principles of the civil law.

Taking into account the controversy over the issue of the relationship between the concepts of "principles" and "basic principles" it seems necessary to clarify in the text of the Civil Code that good faith is a general principle of private law. This would strengthen the principle of good faith in the civil legislation of the Republic of Kazakhstan and have a positive impact on civil circulation, significantly strengthening the protection of the rights of its participants.

Moreover, the consolidation of good faith as a principle of private law will significantly expand the scope of application of this institution, extending its effect to all civil legal relations, including relations on creation, change and termination of civil rights and obligations, protection of rights and interests.

Possible risk of such approach is that the courts will get a strong tool to regulate relations in the form of good faith. This risk can be compensated through control over the judicial practice which can be carried out by the Supreme Court of the Republic of Kazakhstan. Currently the Supreme Court of the Republic of Kazakhstan has experience of generalization and explanation of judicial practice. This experience can be extended to the application of the principle of good faith by the courts.

In the Republic of Kazakhstan, legislative explanations of the Supreme Court are attributed to the law in force and are adopted in the form of regulatory decisions, i.e. as acts containing the norms of law, although the scientific doctrine has not developed a consensus on the legal nature of such legal acts of the Supreme Court of the Republic of Kazakhstan.

In addition to legislative explanations the Supreme Court of the Republic of Kazakhstan also publishes collections with explanations of legal practice -Ylgi, which in Kazakh means "sample". Despite the fact that these collections are not official regulatory legal acts they 
have a respective opinion for the courts. Some Kazakhstan scientists put forward the idea of giving these collections certain legal force.

As a part of the ongoing reform of private law, we attempted to give these collections a recommendatory character, a kind of analogue of the case law (Konussova and Nesterova, 2016).

Unfortunately, this idea was not supported by Kazakhstani academic lawyers and at the moment it's no longer the part of the private law reform project.

However, the Supreme Court of the Republic of Kazakhstan may adopt regulatory decisions that clarify the lower courts the practice of applying certain norms. It is necessary to delineate the boundaries of the principle of good faith through these resolutions which ultimately protects against the abuse of this principle by the courts.

In consideration of the foregoing, it is necessary to include good faith into the Article 2 of the Civil Code of the Republic of Kazakhstan, as well as to clarify it as a principle of law. It should be borne in mind that the current article 8 of the Civil Code of the Republic of Kazakhstan limits the application of the principle of good faith. Thus it seems necessary to extend this principle to all civil relations including relations on the creation, change and termination of civil rights and obligations.

\section{Conclusions}

In the course of the reform of the private law of the Republic of Kazakhstan it became necessary to expand the principle of freedom of contract. In this regard, the developers of the draft of the future law came up with a choice of a possible solution to the issue.

Initially, the most logical was the option of revising the mandatory norms of the civil legislation of the Republic of Kazakhstan to expand the default beginnings of legislation.

However, this option required a lot of work to go beyond the project to implement certain provisions of English law and could not cover all the norms of the civil law. In addition, within the framework of one project, it is impossible to determine all possible options for abusing the principle of freedom of contract or the exceptions to this principle.

In this regard, it was decided to stay on two possible options for expanding the principle of freedom of contract.

Thus, a possible way of expanding the principle of freedom of contract is to transfer to the courts right to interpret controversial rules of the law that do not contain indications of mandatory or decretive nature. This option used in Russia and a number other states.

If the norm does not prohibit the approval of other provisions, nor a direct reference to the right of the parties to agree on other provisions, then the norm shall be determined by the interpretation of the court.

Alternatively it was possible to accept an approach that presumes the discretion nature of the law if it does not have a mandatory prescription. Nevertheless, this approach may entail cases of abuse of the principle of contractual freedom. However, this approach may entail cases of abuse of the principle of contractual freedom, as it will require, as in the first version of the revision of a large number of norms, in order to allow the parties to withdraw from it. Ultimately, it was decided to stop on this option. 
In order to smooth out possible negative effects from the expansion of the freedom of contract, the principle of good faith was also significantly strengthened. Expansion of the principle of freedom of contract will entail the inevitability of improving the system of checks from the unfair behavior of participants in civil turnover. In this regard, the principle of good faith may be a way to limit the principle of freedom of contract.

A significant difficulty was caused by the exclusion from the reform of private law issues of strengthening judicial practice. Nevertheless, even the current legislative mechanisms in the Republic of Kazakhstan can solve the problem of applying the principle of "good faith". In addition to regulatory changes it is necessary to improve systematically the culture of enforcement. The country has gained experience in generalizing and clarifying judicial practice under the leadership of the Supreme Court of the Republic of Kazakhstan, this experience can be extended applying the principle of good faith.

At present, the draft implementation of the norms and provisions of the English contract law into the civil law of the Republic of Kazakhstan is close to completion.

\section{References}

Civil Code of the Republic of Kazakhstan. (1994). Available at http://adilet.zan.kz/eng/docs/K940001000_

Kommentarij k Grazhdanskomu kodeksu Respubliki Kazahstan (Obshchaya chast'). [Comments to the Civil Code of the Republic of Kazakhstan (General part)] Ed.: Sulejmenov M., Basin Yu. (1999). Available at http://online.zakon.kz/Document/?doc_id=1019750

Universal Declaration of Human Rights. (1948). Available at http://www.un.org/en/universal-declaration-human-rights/index.html

Akyn, B., \& Rakhymbai, B. (2017). Implementation of Civil Service Reforms in Post-soviet Kazakhstan: Legal Framework, Opportunities and Challenges, 20(3), Journal of Legal, Ethical and Regulatory Issues. Available at https://www.abacademies.org/journals/journal-of-legal-ethical-and-regulatory-issueshome.html

Basin, Y.G. (2003). Izbrannye trudy po grazhdanskomu pravu [Selected Works on Civil Law]. Almaty: Adilet.

Bernstein, D. (2008). Freedom of Contract. In Liberty of Contract, in Encyclopedia of the Supreme Court of the United States (David S. Tanenhaus ed. 2008). George Mason Law \& Economics Research Paper No. 08-51. Available at SSRN: https://ssrn.com/abstract $=1239749$

Craswell, R. (1995) Freedom of contract. In: Posner E (ed) Chicago lectures in law and economics. Foundation Press, New York, pp. 81-103.

Collins, H. (1994). Good Faith in European Contract Law. Oxford Journal of Legal Studies, 14(2), pp.229-254.

Didenko, A.G. (2000). Kategoriya dogovora, ee mesto i znachenie v postsovetskom prave [The category of the treaty, its place and significance in post-Soviet law]. In Grazhdanskoe zakonodatel'stvo Respubliki Kazahstan: Stat'i, kommentarii, praktika 
[Civil legislation of the Republic of Kazakhstan: Articles, comments, practice]. Retrieved October 19, 2018, from http://online.zakon.kz/Document/?doc id=31455581

Konussova, V. \& Nesterova, Y. (2016). The improvement of civil legislation of the Republic of Kazakhstan based on the implementation of English law provisions. Pravo $i$ gosudarstvo, 3(72), pp.46-50.

Klimkin S.I. Grazhdanskoe pravo i cifry [Civil law and figures] (2014). Available at https://online.zakon.kz/Document/?doc_id=31560918

Lovett, John A. (2018). Good Faith in Louisiana Property Law, 78 La. L. Rev. Available at: https://digitalcommons.law.Isu.edu/lalrev/vol78/iss4/11

Mackaay, E. (2011). Good Faith in Civil Law Systems - A Legal-Economic Analysis. Available at SSRN: https://ssrn.com/abstract $=1998924$

Mikryukov, V.A. (2013). Princip dobrosovestnosti - novyj nravstvennyj ogranichitel' grazhdanskih prav [The principle of good faith - the new moral constraint on civil rights]. Zhurnal rossijskogo prava, 6.

Podshivalov, T. (2018). Protection of property rights based on the doctrine of piercing the corporate veil in the Russian case law. Russian Law Journal, 6(2), pp.39-72.

Poole, J. (2012). Casebook on Contract Law. OUP Oxford; 11 edition, p. 323

Skryabin S.V. Ogranichenie svobody dogovora [Restriction of freedom of contract]. (2003). Retrieved October 19, 2018, from http://online.zakon.kz/Document/?doc_id=30008052

Sulejmenov, M. (2016). Anglijskoe pravo i pravovaya sistema Kazahstana [English law and legal system of Kazakhstan]. Pravo i gosudarstvo, 3(72), pp.37-45.

Trebilcock, M. (1993). The limits of freedom of contract. Cambridge, Mass.: Harvard University Press, pp.33-36.

Wieacker, F. (1956). Zur rechtstheoretische Präzisierung des $\S 242$ BGB. Tübingen, J.C.B. Mohr (Siebeck). 


\title{
THE OBSERVANCE OF HUMAN RIGHT TO FREEDOM FROM TORTURE IN PROFESSIONAL ACTIVITY OF THE NATIONAL POLICE OF UKRAINE (ARTICLE 3 OF THE CONVENTION FOR THE PROTECTION OF HUMAN RIGHTS AND FUNDAMENTAL FREEDOMS)
}

\author{
Andrii Voitsikhovskyi \\ voitsihovsky@gmail.com \\ Associate Professor of the Department of Constitutional and International Law of Faculty 4 of \\ Kharkiv National University of Internal Affairs (Ukraine). Ph.D. in Law. \\ Oleksandr Bakumov \\ bakumov.aleks@gmail.com \\ Associate Professor of the Department of Constitutional and International Law of Faculty 4 of \\ Kharkiv National University of Internal Affairs (Ukraine). Ph.D. in Law. \\ Olena Ustymenko \\ ustimenko2312@gmail.com \\ Associate Professor of the Department of Constitutional and International Law of Faculty 4 of \\ Kharkiv National University of Internal Affairs (Ukraine). Ph.D. in Law. \\ Vadym Seliukov \\ vadim.selyukov@gmail.com \\ Associate Professor of Department of Police Administrative Activity of Kharkiv National University \\ of Internal Affairs (Ukraine). Ph.D. in Law.
}

\section{Abstract}

The article considers the issue of observance by the bodies of the National Police of Ukraine of human right to freedom from torture or inhuman treatment or punishment.

The practice of the European Court of Human Rights testifies that Ukrainians are increasingly applying to the Court for violations of the prohibition of torture or inhuman treatment by the police.

The authors noted that the responsibility of the bodies of the National Police of Ukraine to prevent violations of human rights to freedom from torture or inhuman treatment was enshrined both in national law and in international legal documents, especially in the Convention for the Protection of Human Rights and Fundamental Freedoms of 1950. The application of the provisions of the Convention, as well as the decisions of the European Court of Human Rights as an integral part of its law enforcement practice, will contribute to the development of the protection of human rights in Ukraine.

Summarizing the practice of the European Court of Human Rights in relation to Ukraine regarding violations of Article 3 of the Convention, the authors of the research singled out certain requirements that are binding on the bodies of the National Police of Ukraine.

The observance of national legislation, application of the provisions of the Convention for the Protection of Human Rights and Fundamental Freedoms and the practice of the European Court of Human Rights will contribute the increasing of the public trust and respect for the law enforcement agencies, including the National Police of Ukraine and improving the efficiency of the Ukrainian justice system.

\section{Keywords}

Torture or inhuman treatment, or punishment; European Court of Human Rights; Convention for the Protection of Human Rights and Fundamental Freedoms; National Police of Ukraine.

How to cite this article

Voitsikhovskyi, Andrii; Bakumov, Oleksandr; Ustymenko, Olena; Seliukov, Vadym (2019). "The UN in Conflict Resolution: the case of East Timor". JANUS. NET e-journal of International Relations, Vol. 10, N.0 2, November 2019-April 2020. Consulted [online] on the date of the last visit, https://doi.org/10.26619/1647-7251.10.2.11 


\section{THE OBSERVANCE OF HUMAN RIGHT TO FREEDOM FROM TORTURE IN PROFESSIONAL ACTIVITY OF THE NATIONAL POLICE OF UKRAINE (ARTICLE 3 OF THE CONVENTION FOR THE PROTECTION OF HUMAN RIGHTS AND FUNDAMENTAL FREEDOMS)}

\author{
Andrii Voitsikhovskyi \\ Oleksandr Bakumov \\ Olena Ustymenko \\ Vadym Seliukov
}

\section{Introduction}

One of the most important tasks of the state is to abide Article 3 of the Constitution of Ukraine on the protection of human's life and health, honour and dignity, inviolability and security. In order to protect these rights and freedoms of citizens of Ukraine, the Fundamental Law (Article 28) states that no one shall be subjected to torture or to inhuman or degrading treatment or punishment [1].

Adhering to the specified constitutional requirements is the main duty of law enforcement bodies of Ukraine, in particular the bodies of the National Police of Ukraine, which take actions to eliminate the threats to the life and health of individuals and public security resulting from a criminal offense (Article 23 of the Law of Ukraine "On the National Police")[2].

Accession to the Council of Europe and ratification of the Convention for the Protection of Human Rights and Fundamental Freedoms of 1950 in July 17, 1997 incorporated Ukraine in the European system of human rights protection, which includes not only the obligation to protect and observe the rights and freedoms enshrined in the Convention, but also recognition of the jurisdiction of the European Court of Human Rights. At the same time, this means that the activities of all public authorities of Ukraine, in particular, judicial and law enforcement agencies, their decisions and procedures, which are used, should not be in conflict with the provisions of the Convention.

The observance of human rights by the National Police of Ukraine is increasingly becoming the subject of discussion in the media, in academic community, and is the focus of contentious political debate. Certain cases of torture, ill-treatment, use of evidence obtained through inhuman treatment, lack of effective investigation of applications and communications on this issue cause a serious public response and adversely affect the credibility of the police authorities and the entire national law enforcement system. 
According to Clause 4 of Article 7 of the Law of Ukraine "On National Police of Ukraine": "Police officers under any circumstances are forbidden to promote, perform, incite or to treat tolerantly any forms of tortures, cruel, brutal or degrading treatment or punishment. In case of identification of such actions each police officer shall take immediately all feasible measures on their suppression and it is obligatory to report on direct management on the facts of tortures and intentions of their application" [2]. However, the practice of the European Court of Human Rights testifies that Ukrainians are increasingly applying to the Court, because they were subjected to torture or inhuman treatment by law enforcement workers, including the National Police of Ukraine. The Court has already adopted a lot of decisions on Ukraine's violation of Article 3 "Prohibition of Torture" of the Convention on Human Rights and Fundamental Freedoms (182 cases for the period from 2007 to 2014) [3].

The study of decisions of the European Court of Human Rights concerning the violation of prohibition of torture or inhuman treatment or punishment promotes the interaction of European law with the national law of the states parties to the specified conventions, enabling them to fulfill duly their international legal obligations. Moreover, in 2006 the Law of Ukraine "On the Implementation of Decisions and Application of the European Court of Human Rights Practice" was adopted. According to Article 17, the practice of this court is a source of Ukrainian law, that is, court decisions should be applied along with laws and bylaws of Ukraine [4], however, the practice shows that the police officers actually ignore the requirements of the above-mentioned decisions.

These factors determine the necessity to identify the level and nature of violations of human rights to freedom from torture or inhuman treatment by the National Police of Ukraine, to analyze the practice of the European Court of Human Rights in relation to violation of Ukraine Article $\mathrm{x} b$ of the Convention for the Protection of Human Rights and Fundamental Freedoms for the purpose of scientific generalization and development of requirements and standards of conduct, clear and understandable for police officers, that they must strictly adhere to in the course of professional activities, which indicates the topicality of the subject of this research.

The academic novelty of the results obtained is that the comprehensive analysis gave the possibility to formulate a scientifically substantiated statement of a theoretical and applied nature which is fully directed and can be practically used to address the issues related to the duly observance of human rights to freedom from torture or inhuman treatment by the bodies of the National Police of Ukraine.

\section{Estimating the observance of human right to freedom from torture in professional activity of the National Police of Ukraine}

The authors of the manuscript highlighted the legislative consolidation of the human right to freedom from torture or inhuman treatment, and once again proved its absolute character, the retreat from which is impossible under any circumstances. Police are one of the state institutions whose activities are aimed at respecting human rights and freedoms, including the inadmissibility of torture or inhuman treatment. Unfortunately, the practice of the European Court of Human Rights testifies to systematic violations by the bodies of the National Police of Ukraine of Article 3 of the Convention on Human Rights and Fundamental Freedoms. It is stated that the result of such violations of human 
rights was the loss of public trust in the police and the national law enforcement system in general.

It is noted that the national mechanisms assigned to the police include an important role in respecting and guaranteeing the human right to freedom from torture or inhuman or degrading treatment or punishment. Summarizing the practice of the European Court of Human Rights regarding violations of Article 3 of the Convention on the Protection of Human Rights and Fundamental Freedoms, the authors have developed the requirements for the Ukrainian authorities and the National Police of Ukraine to advance effective protection of human rights and, of course, increase public trust and respect to police and the entire national law enforcement system.

One of the fundamental values of a democratic society, which is enshrined in Article 3 of the Convention for the Protection of Human Rights and Fundamental Freedoms, is protection of the physical integrity of a person, including from causing pain, which leads to severe physical suffering. For one, Article 3 of this Convention provides that "no one shall be subjected to torture or to inhuman or degrading treatment or punishment" [5]. A number of other international legal instruments also prohibit torture and inhuman treatment: Article 5 of the Universal Declaration of Human Rights of 1948, Article 7 of the International Covenant on Civil and Political Rights, of 1966, the United Nations Convention against Torture and Other Cruel, Inhuman or Degrading Treatment or Punishment, of 1984, the European Convention for the Prevention of Torture and Inhuman or Degrading Treatment or Punishment of 1987, Minimum Standard Rules for the Treatment of Prisoners of 1955, Code of Conduct for Law Enforcement Officials of 1979 , and many others.

Torture and inhuman treatment are one of the human rights violations that cause the greatest concern of the global community today. For a long time, torture and inhuman treatment were the main means of obtaining evidence and were widely applied during investigations by law enforcement agencies, including the bodies of the National Police of Ukraine (in the past, the militia). At the same time, the phenomenon of torture and inhuman treatment in law-enforcement agencies remains scantily explored. This is due to the long closed nature of this subject existing for many years, a demonstrative nonrecognition by the officials of the character and scale of this phenomenon.

As a rule, torture and inhuman treatment almost do not exist separately from other types of official misconduct. In most cases, torture and inhuman treatment are the means by which a policeman attempts to obtain information from a person about the commission of an offense by him/her or another person in order to achieve the intended result in the official activities.

The denial of the true scale and the system of torture and inhuman treatment in the National Police of Ukraine, attention only to specific cases, the search for several guilty ones and a complaint about insufficient funding - this is how the approach of the Ministry of Internal Affairs of Ukraine to the solution of this problem looks like. Although the leadership of the state and the ministry has changed, in many respects the approaches have remained the same: the reform of those aspects of the impact of the scale of unlawful police violence is insufficient; statistics on violations committed by employees of the National Police of Ukraine do not reflect the true state of affairs; the procedure for receiving complaints about violation and the procedure for their investigation are still non-transparent and ineffective. 
The statistics show that in the structure of crimes against life and health of a person, torture in Ukraine amounts to: in 2013 -51 crimes; 2014 - 54; 2015 - 73; 2016 - 62; 2017 - 82, 2018 - 163 [6]. Moreover, police officers illegally use physical force and special means.

Criminal proceedings for deliberate bodily blows, torture or other violent acts by police officers with respect to suspects or accused are usually limited to an internal official investigation, and only $3 \%$ of the proceedings are brought to court (in most cases, these proceedings have grave consequences, or so-called public response, causing wide-scale public indignation).

Such a system of response to violations of human rights to freedom from torture or inhuman treatment by officers of the National Police of Ukraine can hardly be considered effective. That is why the level of trust in the figures given to assess the scope of unlawful violence in police is still poor. In addition, the system still has an impact on the number of such reports: every victim of torture or inhuman treatment should report it to the police or the prosecutor's office (which often delegates the case to the police for investigation). There is no point applying to the same agency whose officer has violated human rights. That is why most victims do not report it anywhere, leaving the real scope of violence hidden from statistics. Thus, the methods of collecting and evaluating statistics on violations of human rights to freedom from torture or inhuman treatment by police officers have actually remained the same as before.

In order to study the problems of unlawful violence by the bodies of the National Police of Ukraine, the Kharkiv Institute for Social Research and the Kharkiv Human Rights Protection Group conducted a monitoring sociological study, during which the following estimates were obtained:

Table 1 - Estimated number of victims of unlawful physical violence committed by police during 2004-2017

\begin{tabular}{|l|r|r|}
\hline \multicolumn{1}{|c|}{ Year } & \multicolumn{1}{|c|}{$\begin{array}{c}\text { Number of } \\
\text { victims (\%) }\end{array}$} & $\begin{array}{c}\text { Estimated number of } \\
\text { injured }\end{array}$ \\
\hline 2004 & 2,73 & $1,026,616$ \\
\hline $2004-09$ & 3,50 & $1,319,500$ \\
\hline 2010 & 2,10 & 791,700 \\
\hline 2011 & 2,6 & 980,200 \\
\hline 2015 & 1,30 & 409,080 \\
\hline 2017 & 2,0 & 641,326 \\
\hline
\end{tabular}

Source: Monitorynh nezakonnoho nasylstva v militsii (2004-2017 rr.) / Kol. avt. Kharkiv, Kharkivskyi instytut sotsiolohichnykh doslidzhen, 2017. 17 p.

Table 2 - Estimated number of victims of torture committed by police during investigation during 2004-2017

\begin{tabular}{|l|r|r|}
\hline \multicolumn{1}{|c|}{ Year } & \multicolumn{1}{|c|}{$\begin{array}{c}\text { Number of } \\
\text { victims (\%) }\end{array}$} & $\begin{array}{c}\text { Estimated number of } \\
\text { injured }\end{array}$ \\
\hline 2004 & 0,25 & 93,498 \\
\hline $2004-09$ & 0,3 & 113,331 \\
\hline 2010 & 0,2 & 75,400 \\
\hline 2011 & 0,3 & 113,331 \\
\hline 2015 & 0,2 & 62,935 \\
\hline 2017 & 0,3 & 96,195 \\
\hline
\end{tabular}

Source: Monitorynh nezakonnoho nasylstva v militsii (2004-2017 rr.) / Kol. avt. Kharkiv, Kharkivskyi instytut sotsiolohichnykh doslidzhen, 2017. 19 p. 
These results of the monitoring sociological study significantly differ from the official statistics. These are not final results, but they make it possible to assess the real level of violation of the human right to freedom from torture or inhuman treatment committed by the bodies of the National Police of Ukraine.

The attitude of Ukrainians to the danger of becoming a victim of unlawful violence by police authorities is confirmed by the results of this monitoring study. (in $2009-2.5 \%$, in $2010-1.8 \%$, in $2011-1.5 \%$, in $2015-1.4 \%$, in $2017-3.2 \%$ ). At the same time, this indicator gradually declined year after year, except for 2017 [7, p.27].

The following factors of violation of the human right to freedom from torture and inhumane treatment by the bodies of the National Police of Ukraine were put forward by Ukrainians as primary ones:

- lawlessness of officers who use unlawful methods for work - $(43.5 \%)$;

- poor staff recruitment, as a result of which people with sadistic inclinations join the police $(34.7 \%)$;

- poor professional and cultural level of police officers $(30.5 \%)[7$, p.36].

Responsibilities of national law enforcement agencies and in particular the National Police of Ukraine to prevent violations of prohibition of torture or inhuman treatment are the result of a long process of establishing norms of international and national legislation, as well as a no less long-term and debatable process of their coherence.

Among all existing international legal tools, the Convention for the Protection of Human Rights and Fundamental Freedoms of 1950 is the most respected by the states parties in practice. This is in particular due to the fact that this Convention is legally binding on the states that have acceded to it, and the decisions of the supervisory agencies of the Convention are binding on the signatory states parties. In addition, the monitoring of the proper enforcement of human rights is carried out by the European Court of Human Rights, whose activities are regulated by the Convention, the Rules of the Court and application processing.

By ratifying the Convention for the Protection of Human Rights and Fundamental Freedoms, Ukraine has thus recognized the mandatory jurisdiction of the European Court of Human Rights.

In accordance with Part 1 of Article 32 of the Convention for the Protection of Human Rights and Fundamental Freedoms, the interpretation of its norms is the exclusive competence of the European Court of Human Rights. Therefore, from this perspective, the case law of the Court constitutes the official international interpretation of the Convention for the Protection of Human Rights and Fundamental Freedoms [5].

While exercising its powers to protect human rights guaranteed by the Convention, in particular the right to freedom from torture or inhuman or degrading treatment or punishment, the European Court of Human Rights takes steps aimed at approximating the laws of the States Parties and adopts decisions that directly affect their legal systems. The main purpose of the Court is to interpret and express its position on the practice of the application of the rights and freedoms proclaimed in the Convention. It is envisaged 
that the state, amending its legal system as a part of implementation of the decision of the European Court of Human Rights regarding a complaint of one of its citizens, automatically prevents a similar violation of the rights of other citizens.

At the same time, the States not subject to the European Court of Human Rights decision but having legislative and law enforcement practices similar to those found by the Court as unlawful in relation to other parties to the Convention, may not wait for the decision of the European Court of Human Rights to make timely changes to their national legislation. Such a position of the European Court of Human Rights is particularly relevant in terms of the restoration and observance of fundamental human rights, including the right to freedom from torture or inhuman or degrading treatment or punishment, since the Court establishes certain standards for internal domestic application of Article 3 of the Convention and its interpretation.

Unconditional nature of the guarantee of the protection of rights contained in Article 3 also means that under no circumstances, in accordance with the Convention or another provision of international law, actions that violate this article cannot be justified. In other words, there are no factors that could be considered as justification for prohibited acts within the internal legal systems (armed conflicts, state of emergency, victim's behavior, different external circumstances, etc.) [8, p.380-381].

The answer to the question of what exactly is a "torture, inhuman or degrading treatment or punishment" depends on the circumstances of the particular case.

By dividing the terms "torture" and "inhuman treatment", the European Court of Human Rights applied the principle of determining the gravity of suffering, but under the influence of the United Nations Convention against Torture and Other Cruel, Inhuman or Degrading Treatment or Punishment of 1984, it transformed the position, adding to the main differences the purpose and intentional nature of such actions. Inhuman treatment is deemed both active actions and omission to act of the authorities or their employees, which caused only the moral suffering of the applicant.

There is another difference between the concepts of "torture", "inhuman treatment" and "degrading treatment", apart from the purpose, intention, gravity of suffering, which is an impairment of dignity of a particular person. It has been investigated that torture and inhuman treatment are attacks on human dignity in its absolute meaning, whereas degrading treatment is aimed at denigration the dignity of a particular individual. The European Court of Human Rights has also included the conditions for the detention of prisoners to the qualification of degrading treatment, emphasizing the universal character of the provisions of Article 3 of the Convention for the Protection of Human Rights and Fundamental Freedoms, according to which detained or imprisoned persons have all the rights inherent in the dignity of each person.

Considering the issue of violation of Article 3 of the Convention for the Protection of Human Rights and Fundamental Freedoms, the European Court of Human Rights is based on the doctrine of the minimum level of severity. The essence of this doctrine in a nutshell is that to fall within the scope of Article 3, ill-treatment must be at the minimum level of severity.

The practice of the European Court of Human Rights singles out three basic concepts, which are contained in the contents of Article 3 of the Convention for the Protection of Basic Human Rights and Freedoms regarding the degree of severity of a treatment: 
- $\quad$ torture is an inhuman treatment aimed at obtaining any information or confession for further punishment;

- inhuman treatment or punishment is a behavior that deliberately causes serious moral or physical suffering and should not be justified in the given situation;

- degrading treatment or punishment is a behavior that savagely humiliates an individual before others and forces him/her to give up their will or conscience.

In assessing the level of severity, according to the European Court of Human Rights, such facts as sex, age, and health condition of the victim gain particular importance. The doctrine of the minimum level of severity itself is used to separate torture from inhuman or degrading treatment and punishment [9].

Summarizing the practice of the European Court of Human Rights in relation to cases of violation of the human right to freedom from torture or inhuman or degrading treatment or punishment, at least 5 following requirements regarding the treatment of detained and arrested persons shall be put forward to the bodies of the National Police of Ukraine:

1. Duty to report any injury that happened during a stay under the jurisdiction of police authorities.

2. Duty to provide explanations for each injury that happened during a stay under the jurisdiction of police authorities.

3. Duty to provide explanations regarding the treatment with a person during his/her stay under the jurisdiction of police authorities.

4. Duty to provide explanations on the causes of death and the medical treatment provided to that person until his/her death if the person died during the detention.

5. Duty to provide a satisfactory and plausible explanation of the causes of death if a person died while being under the jurisdiction of police authorities [10].

\section{Analysis of judgments of the European Court of Human Rights concerning violations of Article 3 of the Convention for the Protection of Human Rights and Fundamental Freedoms}

As a part of this study, it is important to clarify the additional requirements contained in the decisions of the European Court of Human Rights concerning Ukraine regarding violations of Article 3 of the Convention binding on the bodies of the National Police of Ukraine. In the following, we shall examine this part of the practice of the European Court of Human Rights.

The case "Kaverzin v. Ukraine" (2013). On January 12, 2001, Kaverzin O. was detained in Kharkiv by militia officers on suspicion of committing several murders and robbery.

After the detention, the applicant was taken to the militia station, where he was allegedly tortured by unknown militia officers in order to obtain testimony to commit crimes. According to the applicant, during such ill-treatment, which continued for several days thereafter, he received an eye injury which eventually resulted in him suffering a complete loss of eyesight. The applicant complained that the state authorities did not provide him with adequate medical treatment, resulting in a disability. 
The applicant complained that there was no effective investigation of the beatings and torture of militia officers. In addition, in the Dnipropetrovsk colony, in spite of his blindness, every time he was taken out of the cell and during short visits with family members he was handcuffed.

The European Court of Human Rights, after considering this case, noted that there is a violation of Article 3 of the Convention. The court reiterates that Article 3 of the Convention requires the careful investigation of reasonable claims of ill-treatment. This means that the authorities should always try in good faith to find out what happened and not to rely on hasty and unreasonable conclusions to close the criminal case. The Court also considers that the non-provision of necessary medical care to persons in places of detention, which is the responsibility of the State, is a violation of Article 3 of the Convention. The Court finds that the applicant's use of handcuffs in the Dnipropetrovsk colony was inhuman and degrading treatment and that there was a violation of Article 3 of the Convention [3].

The case "Kulik v. Ukraine" (2015). On May 4, 2003, Kulik V. was arrested on suspicion of stealing cucumbers from a greenhouse on a vegetable farm, as well as for the commission of an administrative offense (deliberate disobedience and resistance to militia officers).

According to the applicant, on the same day, militiamen beat him at the Chervonozavodskyi District Militia Station in Kharkiv, forcing him to confess to the theft. Subsequently, the applicant granted confessionary evidence.

On May 5, 2003 the applicant turned to the hospital for medical assistance. The doctor recorded the numerous injuries on the body of the applicant and diagnosed brain concussion and a possible fractured nose. The applicant was admitted to the hospital for a course of in-patient treatment in connection with the injuries sustained.

On July 8,2003 , the applicant was inspected by a psychiatrist who had diagnosed him with a psychiatric disorder.

The applicant complained under Article 3 of the Convention that he had been subjected to ill-treatment by militia officers and that there was no effective investigation of the incident.

The European Court of Human Rights, after considering this case, came to the conclusion that the applicant's bodily injury was serious enough and his complaint of ill-treatment was reasonable in terms of Article 3 of the Convention, and therefore demanded an effective investigation to be conducted by the national authorities.

The Court considers that the medical evidence available in the case is sufficient to conclude that on May 4, 2003, on the date when the applicant was detained and he was in the militia station, he suffered a brain concussion and numerous bodily injuries. Medical evidence also suggests that from that date, he had a psychological disorder. Under these circumstances, the Court ruled that the state should be held accountable for the illtreatment that should be qualified as inhuman and degrading treatment. Therefore, there was a violation of Article 3 of the Convention and the state should be held accountable for it [3]. 
The case "Serikov v. Ukraine" (2015). On May 16, 2008 Serikov S. was detained by militia officers and sent to the Kharkiv City Department of the Main Administration of Ministry of Internal Affairs of Ukraine in the Kharkiv region.

During the search of the applicant's personal belongings, the militia found a packet with the substance that, as it was later established, turned out to be cannabis.

According to the applicant he was ill-treated by the militia to make him confess at the militia station. In particular, he argued that he was threatened with rape, beaten with legs and arms on the head and body, and also threatened with weapons. The officers used the "Palestinian hanging"; with his hands handcuffed behind his back, he was hung at a height of one or one and a half meters, and then thrown on the floor face down. He lost consciousness a few times.

On May 17, 2008, the applicant turned to the medical institution, where he was diagnosed with a brain concussion, a soft tissue bruise of the head and chest. The applicant complained that he had been subjected to ill-treatment by militia officers and that the national authorities had not conducted an effective investigation of his allegations of illtreatment. He referred to Articles 3 and 13 of the Convention.

Based on all available material, the European Court of Human Rights considers it established that all bodily injuries were caused to the applicant after his encounter with militia officers on May 16, 2008, and until he left the militia station on that day. For these reasons, the Court finds that the applicant has been subjected to ill-treatment, the state should be held accountable for, and which should be classified as inhuman and degrading. Under these circumstances, the Court concludes that the national authorities did not ensure that the applicant's allegations of ill-treatment were effectively investigated. Therefore, there was a violation of the substantial aspect of Article 3 of the Convention [3].

The case "Pomiliaiko v. Ukraine" (2017). In early November 2008, equipment was abducted from the company where Pomiliaiko S. worked. In connection with the theft, she was summoned to the Ordzhonikidzevskiy District Militia Station in Kharkiv, together with her employee.

Having arrived at the district station, the applicant was pushed into the office, handcuffed with her hands behind her back, even though she did not demonstrate resistance.

The militia officers who were present were intimidating the applicant in order to force her to confess to theft. Having failed to obtain her confession, the militia officers forced her to sit on a chair, put on a polyethylene package on her head and began to choke her. At the same time, they beat her on the head, face, and lips, so that she did not bite through the package. The applicant has lost consciousness several times. When she told the militia officers that she needed to visit the toilet room, one of the police officers hit her in the stomach and head. She lost consciousness again and involuntarily urinated. She repeatedly refused and declared her innocence. The applicant was compelled to write a statement that she had no complaints about the treatment of the militia officers with her. However, from 9 to 27 November 2008, she was in inpatient treatment in connection with a closed craniocerebral injury, brain concussion, soft tissue bruise of the head, injury of upper and lower limbs, injury of anterior abdominal wall, lumbar osteochondrosis and asthenic syndrome. 
The applicant complained that she had been subjected to torture by militia officers and that there had been no effective investigation of her complaints at the state level. Although the applicant referred to the Articles 3 and 13 of the Convention, the Court considers it appropriate to study this complaint only under Article 3 of the Convention.

Taking into account all the considerations on this issue, the European Court of Human Rights considers it sufficiently established that the applicant had been subjected to illtreatment she complained about, which is a violation of Article 3 of the Convention [3].

Thus, based on the above-mentioned decisions of the European Court of Human Rights, the Ukrainian authorities and the bodies of the National Police of Ukraine are obliged to take the following actions:

1. A special medical examination should be conducted upon the complaint about illtreatment of the injured and his/her lawyer.

2. Police agencies are obliged to avoid any cases where the arrest of a person can be interpreted as an excuse to overcome his/her internal resistance and receive confessions.

3. Using force against detained and arrested persons, the police officers must strictly adhere to the principles of necessity and proportionality.

4. Inability to establish civil officers guilty of unlawful violence against a detained person cannot relieve the state from responsibility. Therefore, in case of a reasonable claim by a person about ill-treatment by law enforcement officers, the state should conduct an investigation, which should be: official, effective, independent, open to public control and should provide the opportunity to identify the perpetrators.

The last item deserves special attention not only because it is mentioned in many cases against Ukraine, but also because public access to the results of official investigations of ill-treatment is a rather problematic one.

Today, the practice of the bodies of the National Police of Ukraine provides the victim itself, who suffered from the unlawful actions of the police officer, with very brief information in case of confirmation of such a fact.

It is clear that such an established ill practice mitigates the attempts of non-governmental organizations to analyze the progress of official check of the facts of torture and inhumane treatment, and therefore directly contradicts the requirements of the European Court of Human Rights regarding the availability of such procedures for public control. That is why the civil society for its own part considers it necessary to set an objective for the administration of the Ministry of Internal Affairs and the General Prosecutor's Office of Ukraine to develop procedures for access of civil society institutions to the materials of investigations.

\section{Final considerations}

"The prohibition of torture is absolute, i.e. not subject to any limitation, derogation or relativisation" [11]. Summing up the material presented, we can conclude that the 
problem of observance of the human right to freedom from torture and inhuman treatment in the activities of the bodies of the National Police of Ukraine remains important. This fact is confirmed by the numerous decisions of the European Court of Human Rights concerning Ukraine on violation of Article 3 of the Convention for the Protection of Human Rights and Fundamental Freedoms, according to which Ukraine was found as a state violating human rights to freedom from torture or inhuman or degrading treatment or punishment.

Having analyzed certain cases of the European Court of Human Rights, the main obligations of the states under Art. 3 of the Convention for the Protection of Human Rights and Fundamental Freedoms may be defined. From the general obligation of the state to ensure conventional rights for each person under its jurisdiction other obligations derive connected with the enforcement and observance of only a certain right. These obligations can be negative and positive. Negative obligation of the states enshrined in Article 3 of the Convention has a conventional nature and consists in refraining from any actions which could lead to a breach of this provision. The positive obligations of states assume the use of reasonable and adequate measures to protect the rights that a person has under the Convention.

The prohibition of torture or inhuman treatment, as an international obligation of the state, correspondingly determines the responsibility of law enforcement agencies, including the National Police of Ukraine to prevent torture or inhuman treatment and to effectively investigate each such manifestation.

To reduce the level of torture and inhumane treatment by the National Police officers, it is advisable to take the following steps:

- it is necessary to develop a new system for evaluating the effectiveness of the activities of the bodies of the National Police of Ukraine at the legislative level, which completely abolishes the so-called "ticket quota" system of police work evaluation (it is necessary to abolish the establishment of plans for the disclosure of crimes for a certain period of time);

- $\quad$ in case of a person's detention, police officers should secure the right to access to a lawyer, the right to be examined by a doctor and the right to notify a relative or other third party of such detention;

- the legislative level should enshrine the duty of the bodies of the National Police of Ukraine to record (audio and video) all actions taking place with the participation of persons irrespective of the status (detained, delivered or visitor) who arrived to the police, with the archiving and storage of video materials;

- the administration of the Ministry of Internal Affairs and the National Police of Ukraine should ensure the development of plans for the training of employees, including teaching materials on the complete prohibition of torture or inhuman or degrading treatment or punishment, with the study of the content of specific cases of the European Court of Human Rights on the violation of Ukraine and other states of Article 3 of the Convention for the Protection of Human Rights and Fundamental Freedoms, by generalizing clear and understandable for police officers requirements and standards of conduct which they must strictly adhere to in their professional activities; 
- $\quad$ to ensure public access to the progress and results of investigations of violations of human rights to freedom from torture and inhumane treatment by the National Police of Ukraine.

The implementation of these recommendations by the administration of the Ministry of Internal Affairs and the National Police of Ukraine will contribute to ensuring the human right to freedom from torture or inhuman or degrading treatment or punishment in the course of police professional activity and will contribute to increasing the public trust and respect for the police and the law enforcement system in general.

\section{References}

[1] Konstytutsiia Ukrainy: zakon Ukrainy vid 28.06.1996 No. 254k/96-VR // Baza danykh "Zakonodavstvo Ukrainy" / Verkhovna Rada Ukrainy. Available at: http://zakon.rada.gov.ua/ laws/show/254к/96-вр.

[2] Pro Natsionalnu politsiiu: zakon Ukrainy vid 02.07.2015 No. 580-VIII // Baza danykh "Zakonodavstvo Ukrainy" / Verkhovna Rada Ukrainy. Available at: http://zakon.rada.gov.ua/ laws/show/580-19.

[3] Stattia 3 "Zaborona katuvannia" / Ofitsiynyi sait Ministerstva yustytsii Ukrainy. Available at: https://minjust.gov.ua/m/stattya-3-zaborona-katuvannya.

[4] Pro vykonannia rishen ta zastosuvannia praktyky Yevropeyskoho Sudu z prav liudyny: zakon Ukrainy vid 23.03.2016 No. 3477-IV // Baza danykh "Zakonodavstvo Ukrainy" / Verkhovna Rada Ukrainy. Available at: http://zakon3.rada.gov.ua/laws/show/3477-15.

[5] Convention for the Protection of Human Rights and Fundamental Freedoms // Available at: https://www.coe.int/en/web/compass/the-european-convention-onhuman-rights-and-its-protocols.

[6] Za danymy statystychnoi informatsii Heneralnoi prokuratury Ukrainy // Ofits. sait Heneralnoi prokuratury Ukrainy / Heneralna prokuratura Ukrainy. Available at: https://www.gp.gov.ua/ua/statinfo.html.

[7] Monitorynh nezakonnoho nasylstva v militsii (2004-2017 rr.) / Kol. avt. Kharkiv, Kharkivskyi instytut sotsiolohichnykh doslidzhen, 2017. $100 \mathrm{~s}$.

[8] Andreychenko S.S. Rol praktyky Yevropeyskoho sudu z prav liudyny u rozvytku prava na zakhyst vid katuvan abo neliudskoho chy takoho, shcho prynyzhuie hidnist, povodzhennia abo pokarannia // Pravove zabezpechennia efektyvnoho vykonannia rishen i zastosuvannia praktyky Yevropeyskoho sudu z prav liudyny: materialy mizhnarodnoi naukovo-praktychnoi konferentsii (Odesa, 15 veresnia 2012 r.) / Natsionalnyi universytet "Odeska yurydychna akademiia". Odesa: Feniks, 2012. S. 378-385.

[9] Zamula A.Yu. Mizhnarodno-pravova zaborona katuvannia yak faktor vplyvu na efektyvnist borotby $z$ teroryzmom: dysertatsiia na zdobuttia naukovoho stupenia kandydata yurydychnykh nauk (doktora filosofii): 12.00.11. Kyiv, 2017. 285 s.

[10] Martynenko O.A. Vymohy mizhnarodnoho zakonodavstva u natsionalnomu vymiri: zoboviazannia orhaniv vnutrishnikh sprav Ukrainy u sferi zapobihannia porushen prav 
Vol. 10, No. 2 (November 2019-April 2020), pp. 152-165

The observance of human right to freedom from torture in professional activity of the national police of Ukraine (article 3 of the Convention for the protection of human rights and fundamental freedoms)

Andrii Voitsikhovskyi, Oleksandr Bakumov, Olena Ustymenko, Vadym Seliukov

liudyny. Available at: http:// http://nadoest.com/vimogi-mijnarodnogo-zakonodavstvau-nacionalenomu-vimiri-zobov.

[11]. Manfred Nowak Challenges to the Absolute Nature of the Prohibition of Torture and Ill-treatment $/ /$

Available

at:

https://journals.sagepub.com/doi/abs/10.1177/016934410502300410 